Faculdade de Filosofia, Letras e Ciências Humanas da Universidade de São Paulo

Departamento de Letras Modernas

Programa de Pós-graduação em Estudos Linguísticos,

Literários e Tradutológicos em Francês

MANLIO DE MEDEIROS SPERANZINI

A PESQUISA (in)FINITA DAS COISAS

GEORGES PEREC E A ARTE DO DESIMPORTANTE

\author{
VERSÃO CORRIGIDA \\ o exemplar original se encontra \\ disponível no CAPH da FFLCH
}

São Paulo 
Faculdade de Filosofia, Letras e Ciências Humanas da

Universidade de São Paulo

Departamento de Letras Modernas

Programa de Pós-graduação em Estudos Linguísticos,

Literários e Tradutológicos em Francês

MANLIO DE MEDEIROS SPERANZINI

\title{
A PESQUISA (in)FINITA DAS COISAS GEORGES PEREC E A ARTE DO DESIMPORTANTE
}

\author{
Tese apresentada ao Programa de Pós-Graduação em \\ Estudos Línguisticos, Literários e Tradutológicos em Francês do \\ Departamento de Letras Modernas da Faculdade de Filosofia, Letras e \\ Ciências Humanas da Universidade de São Paulo, para a \\ obtenção do título de Doutor em Letras. \\ Orientadora: Profa. Dra. Claudia Amigo Pino
}

VERSÃO CORRIGIDA

o exemplar original se encontra

disponível no CAPH da FFLCH
De acordo,

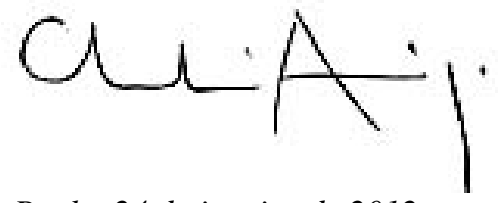

São Paulo, 24 de janeiro de 2012

São Paulo 


\section{Folha de aprovação}

Manlio de Medeiros Speranzini

\section{A pesquisa (in)finita das coisas}

Georges Perec e a arte do desimportante

Tese apresentada ao Programa de Pós-Graduação em

Estudos Línguisticos, Literários e Tradutológicos em Francês do Departamento de Letras Modernas da Faculdade de Filosofia, Letras e

Ciências Humanas da Universidade de São Paulo, para a obtenção do título de Doutor em Letras. Orientadora: Profa. Dra. Claudia Amigo Pino

Aprovado em:

Banca examinadora:

Prof. Dr. Instituição

Julgamento Assinatura

Prof. Dr. Instituição

Julgamento Assinatura

Prof. Dr. Instituição

Julgamento Assinatura

Prof. Dr. Instituição

Julgamento Assinatura

Prof. Dr. Instituição

Julgamento Assinatura 


\section{Agradecimentos}

à orientadora

Claudia Consuelo Amigo Pino

aos professores

Betina Bischof

Marcia Arbex

Marcos Piason Natali

Maria Esther Maciel

aos colegas

Ana Amelia B. Coelho

Carolina Messias

Samira Murad

Raphael Luiz Araujo

e a todos do

Grupo Criação \& Crítica

a meus pais e ao Samir

à Capes pela bolsa que permitiu minha dedicação à pesquisa 
[A ambiguidade] É para mim uma maneira de fazer uma pergunta cuja resposta eu desconheço. ${ }^{1}$

Georges Perec

${ }^{1}$ [...]. C'est pour moi une manière de poser une question dont je ne connais pas la réponse. PEREC. $\underline{\text { Le }}$ bonheur est un processus... on ne peut pas s'arrêter d'être heureux. (1965). In: Conférences, 2003a, p. 47. Entretiens et 


\section{Resumo}

SPERANZINI, Manlio M. A pesquisa (in)finita das coisas. Georges Perec e a arte do desimportante. 2011. 232 p.. Tese (Doutorado). Faculdade de Filosofia, Letras e Ciências Humanas da Universidade de São Paulo, Universidade de São Paulo, São Paulo, 2011.

Esta pesquisa trata de reconhecer e localizar na obra do escritor francês Georges Perec (1936-1982) o que instiga uma produção significativa ligada à Arte Contemporânea por meio do diálogo com três artistas: Arman, Joe Brainard e Édouard Levé. A parte da sua obra que interessa à pesquisa é aquela fixada no real, no espaço, nos lugares, nos rituais e procedimentos repetitivos, no cotidiano e nas coisas materiais que constroem um mundo de desimportâncias - um mundo comum que serve de pano de fundo às ações diárias do banal urbano. A pesquisa está dividida em três capítulos, cada um deles centrado numa maneira particular de agrupar as coisas: no primeiro, dedicado à acumulação, procura-se diferenciar a 'coisa' do 'objeto' e identificar como os valores da sociedade de consumo se apresentam nas obras de Perec e de Arman; no segundo, dedicado à coleção, o interesse são as coisas comuns, o cotidiano indistinto, e a formulação de regras que ajudam Perec e Joe Brainard a compor um sentido para seus fragmentos de lembranças; já no terceiro e último capítulo, é o arquivo que guarda documentos, resultado de projetos de seus criadores, que vai permitir a Perec e a Édouard Levé encararem seus não-lugares para revelar "o que acontece quando não acontece nada".

Palavras-chave: Georges Perec, Arte Contemporânea, Literatura Francesa, Coisas, Espaços, Cotidiano. 


\begin{abstract}
SPERANZINI, Manlio $M$. The (never)-ending research of things: Georges Perec and the art of the unimportant. 2011. 232 p.. Tese (Doutorado). Faculdade de Filosofia, Letras e Ciências Humanas da Universidade de São Paulo, Universidade de São Paulo, São Paulo, 2011.
\end{abstract}

This research aims at recognizing and locating, in the work of the French writer Georges Perec (1936-1982), some of the elements of his production that can be seen as significantly linked to Contemporary Art. This process of recognizing and location will be take shape through the dialogue with three artists: Arman, Joe Brainard and Édouard Levé. The part of Perec's work that interests this research is the one grounded in reality, in the urban space, in places, rituals and repetitive procedures, in everyday life and in material things that make up a world of irrelevance - a common world that serves as background to the daily actions we see in ordinary urban life. This research is divided into three chapters, each one of them focusing on a particular way of grouping things: the first one which is dedicated to the accumulation, tries to differentiate the concept of 'thing' from the notion of 'object' and identify how the values of consumer society appear in the works of Perec and Arman; the second chapter, which is dedicated to the collection focuses on shared things, on the indistinctive aspect of everyday life, and on the formulation of rules that help Perec and Joe Brainard make sense of the fragments of their memories; now, in the third and final chapter, it is the file (which results from the artists' projects) that will allow Perec and Édouard Levé to envisage their non-places to reveal "what happens when nothing happens".

Keywords: Georges Perec, Contemporary Art, French Literature, Things, Spaces, Everyday life. 


\section{Résumé}

SPERANZINI, Manlio M. La recherche (in)finie des choses. Georges Perec et l'art du sans importance. 2011. 232 p.. Tese (Doutorado). Faculdade de Filosofia, Letras e Ciências Humanas da Universidade de São Paulo, Universidade de São Paulo, São Paulo, 2011.

Cette recherche a pour but de reconnaître et de relever, dans l'œuvre de Georges Perec (1936-1982), des éléments qui puissent relier, de manière significative, sa production littéraire à l'art contemporain, à travers un dialogue avec trois artistes: Arman, Joe Brainard et Édouard Levé. La partie de son œuvre qui intéresse à cette recherche est celle ancrée au réel, aux espaces, aux lieux, aux rituels et aux procédures répétitives, au quotidien et aux choses matérielles qui composent un monde de choses sans importance - un monde commun qui sert de bruit de fond aux actions quotidiennes de la banalité urbaine. La recherche est divisée en trois chapitres, chacun se concentrant sur une manière particulière de regrouper les choses. Dans le premier chapitre, dédié à l'accumulation, on essaie de différencier 'la chose' de 'l'objet', et d'identifier comment les valeurs de la société de consommation se présentent dans l'œuvre de Perec et d'Arman. Dans le deuxième, dédié à la collection, on s'intéresse aux choses communes, au quotidien indistinct et à la formulation des règles qui permettent à Perec et Joe Brainard de donner un sens à leurs fragments de souvenirs. Pour le troisième et dernier chapitre, ce sont les fichiers, qui, tout en préservant les documents issus des projets de ses créateurs, permettront à Perec et Édouard Levé d'envisager leurs non-lieux pour nous révéler "ce qui se passe quand il ne se passe rien".

Mots-clés: Georges Perec, Art Contemporain, Littérature Française, Choses, Espaces, Quotidien. 


\section{Lista de Ilustrações}

Figura 1 (página 59) - Arman. Malheur aux barbus [Azar dos barbudos] (1960). Acumulação de barbeadores elétricos em caixa de madeira e Plexiglas, $101 \mathrm{x}$ 60,5 x [?] cm. In: Arman, 2010, p. 127.

Figura 2 (página 60) - Pierre Dac, Francis Blanche. Confession de Furax [Confissão de Furax], (Malheur aux barbus), vol. 2, 1952. Texto da série radiofônica. Disponível em: <http://claudemesplede.com/2009/02/pierre-dac-roi-dufeuilleton-loufoque/>. Acesso em 29 set. 2011.

Figura 3 (página 69) - Arman realizando Poubelle des Halles [A lixeira de Halles], (1961), tendo à esquerda uma caixa com acumulações. In: Arman, 2010, p. 60.

Figura 4 (página 70) - Alain Resnais. Sapatos encontrados em um Campo de Concentração. Fotograma do filme: Nuit et brouillard [Noite e Neblina], (1955). BUCHLOH. Plenty or nothing: from Yves Klein's le Vide to Arman's Le Plein. In: Premises, 1998, p. 96.

Figura 5 (página 90) - Georges Perec. La disparition, 2004b, pp. 304-305.

Figura 6 (página 95) - Ernie Bushmiller. Nancy (detalhe) (23/04/1961). Disponível em: <http://2.bp.blogspot.com/ PBO1yT5EYg/S0 N5u WoxI/AAAAAAAAOpc/RShS OnnAFmI/s1600-h/bushmiller 19610423 nancy.jpg.> Acesso em 03 jul. 2011.

Figura 7 (página 96) - Andy Warhol. Nancy (1961). Pintura com polímero sintético sobre tela. $101 \times 135 \mathrm{~cm}$. Disponível em: <http://www.mcah.columbia.edu/dbcourses/item.cgi $?$ id $=42566 \&$ template $=$ su bmagnify\&table=items>. Acesso em 02 jul. 2011.

Figura 8 (página 100) - Joe Brainard em seu apartamento, Nova York (1975). In: LEWALLEN. Joe Brainard, 2001, p. 41.

Figura 9 (página 102) - Joe Brainard e Frank O'Hara. S/ título (Bingo, or "Guess where I found this?!!") [Bingo, ou "Adivinha onde eu encontrei isso?!!"], (1964). Colagem com técnica mista, $25,4 \times 20,3 \mathrm{~cm}$. In: BRAINARD. The Nancy book, 2008, p. 77. 
Figura 10 (página 105) - Joe Brainard. If Nancy was a boy [Se Nancy fosse um menino], (1972). Guache e tinta sobre papel, 27,9 x 20, $3 \mathrm{~cm}$. In: BRAINARD. The Nancy book, 2008, p. 33.

Figura 11 (página 105) - Joe Brainard. If Nancy was a drawing by Leonardo da Vinci [Se Nancy fosse um desenho de Leonardo da Vinci], (1972). Tinta sobre página impressa de livro, 35,5 x $26 \mathrm{~cm}$. In: BRAINARD. The Nancy book, 2008, frontispício.

Figura 12 (página 105) - Joe Brainard. If Nancy was a De Kooning [Se Nancy fosse um De Kooning], (1972). Técnica mista, 30,4 x 22,8 cm. In: BRAINARD. The Nancy book, 2008, p. 63.

Figura 13 (página 105) - Joe Brainard. If Nancy was an ashtray [Se Nancy fosse um cinzeiro], (1972). Guache sobre papel, 30,4 x 22,8 cm. In: BRAINARD. The Nancy book, 2008, p. 38.

Figura 14 (página 113) - Joe Brainard. I remember, 2006, p. 134.

Figura 15 (página 115) - Joe Brainard, Untitled (Various images) [Sem título (Várias imagens)], (1972). Guache, lápis e tinta sobre papel, 35,5 x 27,94 cm. (1972). In: LEWALLEN. Joe Brainard, 2001, p. xii.

Figura 16 (página 119) - Geores Perec. Je me souviens (Les choses communes I), 2004a, p. 55.

Figura 17 (página 130) - Os 'lugares' de Perec. In: BELLOS. Georges Perec, 1994, p. 592.

Figura 18 (página 131) - Biquadrado latino de ordem 12. In: BELLOS. Georges Perec, 1994, p. 442.

Figura 19 (página 151) - Édouard Levé. Fuvres, 2002, p. 87.

Figura 20 (página 156) - Édouard Levé. Entrée de Paris [Entrada de Paris], fotografia. In: LEVÉ. Amérique, 2006, s/ no p.

Figura 21 (página 157) - Édouard Levé. Supermarché de Calcutta [Supermercado de Calcutá], fotografia. In: LEVÉ. Amérique, 2006, s/ nº p.

Figura 22 (página 158) - Édouard Levé. Habitante de mobile home de Delhi [Moradora de trailer de Delhi], fotografia. In: LEVÉ. Amérique, 2006, s/ no p. 
Figura 23 (página 164) - Alunos de John Baldessari. I will not make any more boring art [Eu não farei mais arte chata], (1971). In: GODFREY. Conceptual Art, 2001, p. 196.

Figura 24 (página 168) - Vito Acconci. Step piece [Peça do degrau], (1970). ACCONCI. Steps into performance (And out) (1979). In: STILES; SELZ. Theories and documents of contemporary art, 1996, p. 760.

Figura 25 (página 169) - Vito Acconci. Step piece [Peça do degrau], (1970). ACCONCI. Steps into performance (And out), (1979). In: STILES; SELZ. Theories and documents of contemporary art, 1996, p. 761.

Figura 26 (página 172) - Arte \& Linguagem. Índice 01 1972. Fotografia da Instalação na Galerie Nationale du Jeu de Paume, Paris, 1994. In: WOOD. Arte Conceitual, 2002, p. 53.

Figura 27 (página 173) - Arte \& Linguagem. Índice 01 1972. Textos para consulta na gaveta do Arquivo (detalhe). In: ALBERRO; STIMSON. Conceptual art: a critical anthology, 2000, p. 266.

Figura 28 (página 184) - Pierre Getzler. Place Saint-Sulpice, 1974, (fotografias). In: AA Files 45/46, 2001, p. 126.

Figura 29 (página 185) - Pierre Getzler. 'Café de la Mairie', place Saint-Sulpice, 1974, (fotografias). In: AA Files 45/46, 2001, pp. 124, 127 / NEEFS; HARTYE. Georges Perec. Images, 1993, p. 134.

Figura 30 (página 193) - Édouard Levé. Entrée d'Angoisse [Entrada de Angústia], fotografia. In: LEVÉ. Reconstitutions. Angoisse, 2008a, s/ nº p.

Figura 31 (página 195) - Édouard Levé. École d'Angoisse [Escola de Angústia], fotografia. In: LEVÉ. Reconstitutions. Angoisse, 2008a, s/ nº p.

Figura 32 (página 197) - Édouard Levé. Sortie d'Angoisse [Saída de Angústia], fotografia. In: LEVÉ. Reconstitutions. Angoisse, 2008a, s/ nº p.

Figura 33 (página 205) - Georges Perec. W ou le souvenir d'enfance, 2003d, p. 89.

Figura 34 (página 206) - Georges Perec. la page [a página] (detalhe). In: Espèces d'espaces, 1994a, p. 17. 


\section{Lista de Tabelas e Listas}

Tabela 1 (página 132) - Distribuição dos textos do projeto Lieux

Tabela 2 (página 133) - Correspondência lugares/números no projeto Lieux.

Tabela 3 (página 183) - As seções de Tentative d'épuisement d'un lieu parisien.

Lista 1 (página 146) - As seções que tratam de 'coisas' em O livro de travesseiro de Sei Shônagon.

\section{Lista de abreviaturas}

As citações das obras estudadas virão acompanhadas da sigla e do(s) número(s) da(s) página(s) correspondente(s).

Títulos de Georges Perec

Les choses, une histoire des années soixante

Je me souviens - Les choses communes I

Espèces d'espaces

$W$ ou le souvenir d'enfance

Tentative $d$ 'épuisement d'un lieu parisien
Siglas

(Jms)

(Telp)

\section{Título de Joe Brainard}

I remember

Título de Sei Shônagon

O Livro de travesseiro

(OIt)

Título de Édouard Levé

Fuvres 


\section{Sumário}

Introdução

p. 14

1. A acumulação, ou, o que só aumenta ................................ p. 25

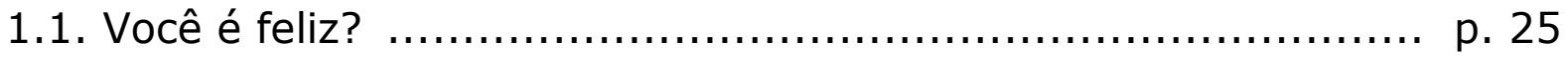

1.1.1. Que coisa é essa? ............................................. p. 28

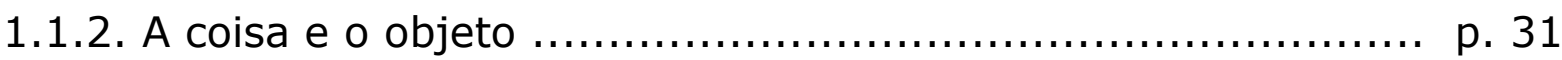

1.2. Perec e a compulsão pelas coisas ................................... p. 34

1.2.1. De olho nas coisas ........................................... p. 40

1.2.2. Os modelos de Les choses ..................................... p. 48

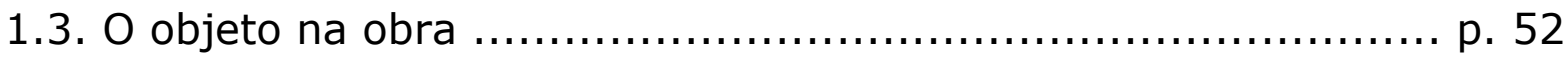

1.3.1. Arman, um coletor do seu tempo ............................. p. 55

1.4. As coisas como 'o aquém' e 'o além' do objeto ...................... p. 61

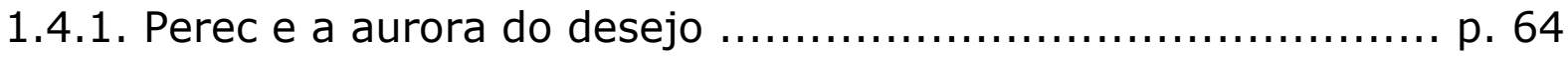

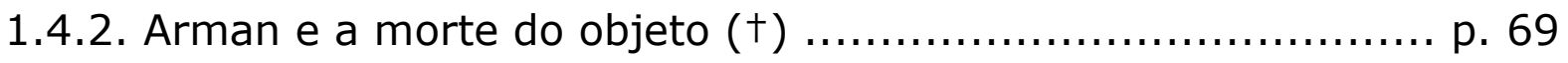

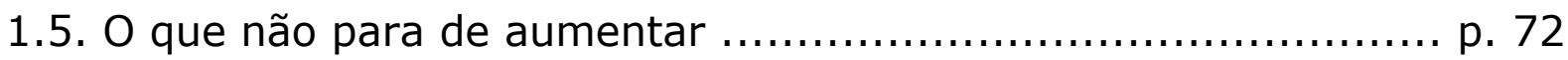

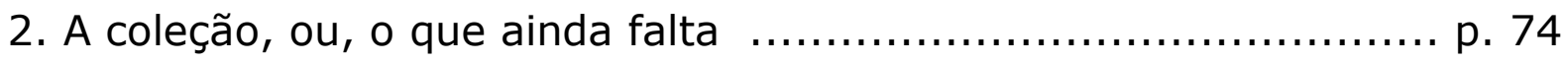

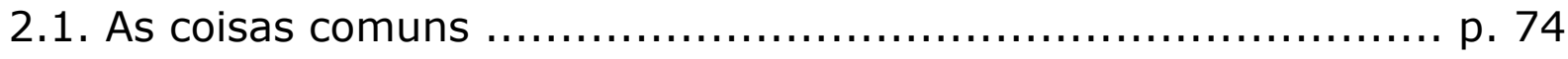

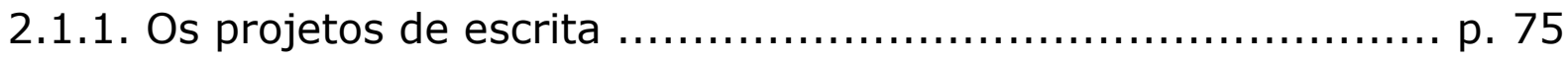

2.1.2. Um novo rumo para as coisas ................................. p. 77

2.1.2.1. Tradução: Aproximações de quê? ................................ p. 80

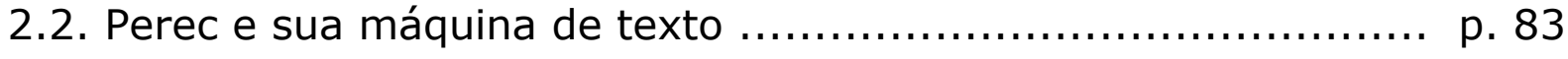

2.3. As coisas do Pop, ou, um objeto de segunda mão ................. p. 93 
2.3.1. Brainard: quando o material faz tudo

p. 98

2.4. O estatuto da coleção

p. 106

2.5. O que eles se lembram, ou, o exercício da coleção p. 110

2.5.1. I remember p. 110

2.5.2. Je me souviens p. 116

2.6. O que Perec não esquece p. 123

3. O arquivo, ou, o que está por ser feito p. 125

3.1. Escrever para viver, ou, viver para escrever? p. 125

3.1.1. Um projeto de vida e de morte p. 126

3.1.2. O verdadeiro realismo, ou, as lições de uma dama do século XI p. 137

3.2. Uma arte do desimportante p. 147

3.2.1. Édouard Levé e o neutro p. 151

3.3. A ideia como máquina de fazer arte p. 160

3.3.1. O arquivo como promessa p. 170

3.4. (Não)Lugares manual de instruções p. 175

3.4.1. Tentative d'épuisement d'un lieu parisien: uma escrita fotográfica .... p. 176 3.4.1.1. Tradução: Seção 4, 18/10/1974, 17h10, Café de la Mairie p. 187

3.4.2. Angoisse: uma fotografia literária p. 190

3.5. O que não é dado ver p. 198

(In)Conclusão p. 202

Referências Bibliográficas p. 215 


\section{Introdução}

O tempo que passa (minha História) deposita resíduos que se empilham: fotos, desenhos, corpos de hidrográficas há muito tempo ressecadas, pastas, garrafas descartáveis e garrafas retornáveis, embalagens de charutos, caixas, borrachas, cartões postais, livros, poeira e bibelôs: isso que eu chamo de meu tesouro. ${ }^{2}$ (Ee, p. $37)$.

Foi durante o mestrado que me aproximei da obra de Georges Perec, enquanto eu estudava a relação do individuo com o espaço da casa, pensando em compor o que configuraria o sentimento de quem se sente abrigado e pertencente a um lugar: um habitante, ou melhor, um morador, portador de um sentimento único: o sentimento morador ${ }^{3}$. Ainda que o foco da pesquisa fosse tratar de um sentimento comum, se não a todos, pelo menos a muitos, o deflagrador da pesquisa fora uma experiência pessoal - um daqueles momentos que nos fazem tomar consciência de que a volta seria impossível ${ }^{4}$.

Enquanto estudava essa relação do indivíduo com sua casa, senti a necessidade de buscar, além de uma bibliografia teórica, uma maneira de me aproximar da vida real que ampliasse e tirasse o foco da única relação legítima possível com esse assunto - a minha. Para isso recorri, num primeiro momento, à obra de dois artistas - Christian Boltanski e Sophie Calle - que haviam incorporado em seus trabalhos observações, depoimentos ou mesmo fantasias do universo doméstico e que eu pensava poderia ser a base da pesquisa. Instigado pelo orientador e, em função das disciplinas que cursava, me fixei nas ideias do filósofo Gaston Bachelard - e em especial, seu livro A poética do espaço - e parti para desenvolver estratégias e procedimentos que me permitiram compor um grupo de colaboradores que,

${ }^{2}$ Le temps qui passe (mon Histoire) dépose des résidus qui s'empilent: des photos, des dessins, des corps de stylos-feutre depuis longtemps desséchés, des chemises, verres perdus et des verres consignés, des emballages de cigares, des boîtes, des gommes, des cartes postales, des livres, de la poussière et des bibelots: c'est ce que j'appelle ma fortune.

Todas as obras de Georges Perec citadas correspondem às edições francesas. Todas as traduções da obra de Georges Perec e das obras de outros autores citados na pesquisa, quando não houver a menção do nome do tradutor nas referências bibliográficas no final da tese, serão do autor. Todos os destaques que aparecem em negrito nas citações, quando não houver menção contrária, serão do autor.

${ }^{3}$ SPERANZINI. Arquiteturas possíveis, 2005.

4 Trata-se do desaparecimento da casa de meus avôs paternos, casa que eu frequentava desde a infância, onde morei por quinze anos e tive meu primeiro estúdio de desenho: rua Sud Menucci, 261, Vila Mariana (São Paulo). Alguns anos antes de iniciar o Mestrado, ao passar por aquela rua, eu descobrira que a casa fora demolida, restando apenas um muro alto que deixava ver, como vestígio da antiga casa, apenas alguns pedaços do muro original de pedras marrons. A fotografia desse muro que abre e fecha a dissertação também fez parte da minha exposição individual: À revelia da luz. Espaço de Artes UNICID (Universidade Cidade de São Paulo). São Paulo, 2001. Cf. SPERANZINI. Op. cit., pp. 11, 87. 
instigados por jogos que eu propunha, foram gerando um corpo inédito de informações. Todo esse material resultaria no segundo volume - um livro de artista - que acompanhou a dissertação propriamente dita.

Entre as dificuldades enfrentadas por aquela pesquisa, e que foram direcionando meus interesses para a literatura, estava o trabalho direto com o texto que resultava da relação com o grupo de colaboradores. Seus depoimentos deveriam, ao longo do mestrado, fornecer as informações necessárias à delimitação e compreensão dos vários campos estudados: o espaço, a intimidade doméstica, os objetos, os afazeres etc. A transcrição pura e simples das gravações de suas falas não revelavam a maneira calorosa, sentimental, engraçada, envergonhada com que esses autores me comunicavam suas experiências durante nossos encontros. Ao invés de ser o editor dessas falas, eu decidi assumir a opção de ser o escritor dos relatos das vivências domésticas dos colaboradores. O resultado disso foi uma pluralidade de vozes, sentimentos, sensações, lembranças e racionalismos que eu não imaginava encontrar. Para conseguir selecionar, organizar, manipular todo o material recebido e direcioná-lo para a pesquisa, eu me repetia, a cada exercício de escrita, a pergunta: o que é habitar? A obra de Perec foi importante por isso: ao invés de me dar respostas, ela me amparou e estimulou a produzir uma pesquisa que continuasse perguntando ao leitor:

\footnotetext{
Habitar um quarto, o que é? Habitar um lugar é se apropriar dele? O que é se apropriar de um lugar? A partir de quando um lugar se torna realmente seu? É quando colocamos de molho três pares de meias em uma bacia de plástico rosa? É quando requentamos o macarrão num fogareiro? É quando já utilizamos todos os cabides desemparelhados do guarda-roupa? É quando prendemos com tachinhas na parede um cartão postal antigo representando o Sonho de Santa Úrsula de Carpaccio? É quando sentimos os suplícios da espera, ou as exaltações da paixão, ou os tormentos da dor de dentes? É quando penduramos nas janelas as cortinas que gostamos, instalamos papéis de parede e polimos o assoalho? ${ }^{5}$ (Ee, p. 36).
}

Refiz aqui esse trajeto para esclarecer - e de certo modo, justificar - minha chegada ao tema proposto para o Doutorado no campo da Literatura Francesa. Tento assim, também, preparar o leitor para o que ele encontrará pela frente: uma literatura que aos poucos se

\footnotetext{
${ }^{5}$ Habiter une chambre, qu'est-ce que c'est? Habiter un lieu, est-ce se l'approprier? Qu'est-ce que s'approprier un lieu? A partir de quand un lieu devient-il vraiment vôtre? Est-ce quand on a mis à tremper ses trois paires de chaussettes dans une bassine de matière plastique rose? Est-ce quand on s'est fait réchauffer des spaghettis au-dessus d'un camping-gaz? Est-ce quand on a utilisé tous les cintres dépareillés de l'armoirependerie? Est-ce quand on a punaisé au mur une vieille carte postale représentant le Songe de sainte Ursule de Carpaccio? Est-ce quand on y a éprouvé les affres de l'attente, ou les exaltations de la passion, ou les tourments de la rage de dents? Est-ce quand on a tendu les fenêtres de rideaux à sa convenance, et posé les papiers peints, et poncé les parquets?
} 
desvencilhará da fábula e se voltará para o que é acessório, subalterno, pano de fundo e que, mesmo com muitos vestígios da literatura de outros autores como Flaubert, Queneau, Roussel, Melville, Rabelais, ainda assim não era exatamente aquilo, mas outra coisa.

O foco então não é exatamente a obra perequiana, mas uma parte dela, justamente aquela que, fixada no real e nas coisas, constrói um mundo de desimportâncias: o mundo segundo 'G. P.'. Com o interesse nas coisas do cotidiano e do real concreto, a escrita que resulta dessa experiência tem também valor material e é geradora de expressão plástica que, ao invés de provocar deleite e prazeres estéticos, faz pensar. Parece complicado? Com a ajuda da obra de três artistas plásticos (dois deles também escritores), alguns valores da obra perequiana ganham destaque, ficam mais estimulantes e amigáveis.

A pesquisa começa efetivamente quando, em 2007, ao cursar a disciplina Espaço e Literatura ministrada pela Profa. Dra. Claudia Amigo Pino na área de Estudos Línguisticos, Literários e Tradutológicos em Francês (FFLCH/USP), eu sou apresentado ao seu livro: $A$ ficção da escrita ${ }^{6}$, livro que toca na utopia perequiana ao tomar como objeto de pesquisa o livro 53 jours, última obra de Perec que, mesmo inacabada, é potente o suficiente para estimular e dar fôlego à pesquisadora em suas análises e reflexões sobre o trabalho com manuscritos no estudo do processo criativo do seu autor.

Esse tipo de força que impulsiona novas iniciativas ficou mais evidente quando, nesse mesmo ano, foi anunciado o projeto de um volume de Les Cahiers Georges Perec dedicado ao diálogo da obra perequiana com a Arte Contemporânea ${ }^{7}$ e que deveria coincidir com uma exposição que comemoraria os trinta anos da publicação de seu livro mais famoso: La Vie mode d'emploi. Mas antes de entrar diretamente no que trata a tese, acredito ser necessário trazer algumas informações sucintas sobre esse autor que, ao longo do texto, ganhará informações complementares.

Georges Perec nasceu em Paris em 1936. Filho de judeus poloneses, ele ficou órfão durante a guerra e foi criado pela família da irmã de seu pai. Publicou seu primeiro livro em 1965 e dois anos depois já participava do OuLiPo - grupo de escritores e matemáticos que ainda hoje pesquisa regras e procedimentos de escrita. Faleceu em 1982, aos 46 anos de idade.

Sua produção, caracterizada pela pluralidade de temas, formas e gêneros, também se expandiu para a escrita de peças teatrais, textos para o rádio, adaptações para o cinema,

\footnotetext{
${ }^{6}$ PINO. A Ficção da Escrita, 2004.

${ }^{7}$ Projetado para 2008, esse volume só seria publicado no final de 2010 e colocado à venda em 2011. Cf. Cahiers Georges Perec no 10. Perec et L'Art Contemporain, 2010.
} 
palavras cruzadas, artigos, críticas e narrativas diversas para jornais e revistas. Ele tinha a aspiração de "escrever tudo que fosse possível a um homem de seu tempo escrever".

Em 2008, comemorando os 30 anos da publicação de seu livro mais famoso, dois museus franceses organizaram a exposição "regarde de tous tes yeux, regarde". L'art contemporain de Georges Perec ${ }^{8}$ ["olhe bem tudo, olhe". A arte contemporânea de Georges Perec], com obras de 70 artistas vindas de diversas coleções públicas francesas. Os curadores tomaram para título da exposição a epígrafe utilizada por Perec para o livro homenageado, título de um capítulo de Michel Strogoff, de Jules Verne.

Viajei até a pequena cidade de Dole para ter uma experiência real com os trabalhos que os curadores da exposição entendiam dialogar com a obra perequiana. A opção da curadoria foi a de selecionar as obras que se aproximassem dos quatro grandes campos de questionamentos que o próprio autor havia, num artigo, definido para sua obra ${ }^{9}$ : o cotidiano, a regra do jogo, a autobiografia e o romanesco. O espaço do museu - um antigo pavilhão militar do século XVIII -, composto de várias salas distribuídas por três andares, compartimentava bastante a distribuição dos trabalhos e, sem ter pensado num tipo de divisão e/ou estrutura mais evidente para o que se mostrava, a exposição resultou num labirinto que, mesmo com vários atrativos, não dispunha de qualquer 'fio de Ariadne'. No meio de tanta diversidade, o que poderia ser potencialidade resultou em diluição - e isso me serviu de alerta para o trabalho da tese. Mesmo lidando com o plural da obra perequiana, eu deveria restringir ao que fosse um indicativo de pluralidade e não à pluralidade em si. O sentido mais evidente do que foi apresentado na mostra francesa parece ser mesmo o desdobramento da obra que abre a exposição: La boîte-en-valise ${ }^{10}$ [A caixa como mala], de Marcel Duchamp e por sua frase célebre: "é o observador que faz a obra" ${ }^{11}$. Eu entendia que, para esclarecer a potencialidade da obra perequiana para a arte contemporânea, deveria haver indicativos mais potentes que estimulassem e direcionassem o trabalho do leitor/observador, de modo a fazer disso uma atividade mais divertida e proveitosa. Além disso, a obra em questão de Duchamp é

\footnotetext{
8 "regarde de tous tes yeux, regarde". L'art contemporain de Georges Perec. Exposição apresentada no Museu de Belas Artes de Nantes (27 junho a 12 de outubro de 2008) e no Museu de Belas Artes de Dole (21 de novembro de 2008 a 21 de fevereiro de 2009).

${ }^{9}$ Cf. PEREC. Notes sur ce que je cherche. (1978). In: Penser / Classer, 2003c, pp. 9-12.

${ }^{10}$ La Boîte-en-valise (1936 - 1942), reedição de 1966. Caixa de papelão forrada, contendo 80 réplicas de obras do artista em miniatura, reproduções e fotografias $(9,5$ x 38,5 x $31 \mathrm{~cm})$. Lyon, Musée d'art contemporain. Cf. CHAVANNE. Marcel Duchamp. In: “regarde de tous tes yeux, regarde”, 2008, pp. 86-87.

11 “C'est Le regardeur qui fait l'œuvre”. Marcel Duchamp apud DARY; CHAVANNE. Introduction. In: "regarde de tous tes yeux, regarde", 2008, p. 7.
} 
uma seleção de reprocuções miniaturizadas de trabalhos seus das primeiras décadas do século $\mathrm{XX}$, o que já é por si um questionamento sobre o próprio estatuto do que se entende por 'arte contemporânea' ${ }^{12}$.

De qualquer modo, foi interessante ter que definir algumas obras apresentadas na exposição como pontos de referência para a minha orientação, e aí as descobertas mais instigantes e bem humoradas foram: a obra de Daniel Firman ${ }^{13}$ - que gerou meu primeiro ensaio/experimento sobre o exercício da acumulação ${ }^{14}$-, e a de Édouard Levé - um dos três artistas cuja produção trago para a tese: um artista que nos fala de uma coisa e mostra outra ${ }^{15}$.

$\mathrm{Na}$ tese, o objetivo não é o de apontar ou localizar na obra perequiana reflexos e/ou ligações e/ou influências da arte contemporânea, muito pelo contrário, a ideia é buscar nessa obra o que facilita e instiga outros autores e artistas a manterem os livros de Perec em constante ebulição. Em vida, Perec raramente manifestou algum interesse pelo trabalho de outros artistas que, como ele, atuavam na vanguarda de seus campos. Como explica Jean-Max Colard num artigo de 2003, Perec não revelava um interesse particular pela arte contemporânea, demonstrando até mesmo certa indiferença pela efervescência e pelo arrojo do panorama cultural francês dos anos sessenta e setenta:

[...] como explicar, portanto que seja ele, Georges Perec, esse autor no fundo tão anacrônico na sua relação com a arte do seu tempo, que seja ao mesmo tempo o

12 Além de ter uma obra que é referência para muitas das iniciativas que, a partir dos anos sessenta, configurariam o que entendemos agora por 'arte contemporânea', a presença de uma obra de Duchamp na abertura da exposição também se deve ao fato do artista ter participado do OuLiPo - grupo do qual Perec também participaria a partir de 1967. Sobre essa relação cf.: BÉNABOU. Duchamp à l'Oulipo ou Un secret trop bien gardé. In: “regarde de tous tes yeux, regarde”, 2008, pp. 74-84.

${ }^{13}$ Daniel Firman (1966) apresenta a assemblage entitulada Gathering [Ajuntamento] (2000) na qual vemos apenas as pernas de um homem que tem o tronco quase que totalmente coberto pelos objetos que carrega Cf. FLEURY. Daniel Firman. In: "regarde de tous tes yeux, regarde”, 2008, p. 100.

${ }^{14}$ Nesse artigo apresento o livro Les choses de Perec e a assemblage de Firman, e enfatizo o que encontro nessas obras de acumulativo. É ainda uma 'visão à distância' dessas obras: do texto de Perec eu descrevo a fábula e da assemblage de Firman trago quatro vistas distintas - exercício possível porque eu estive presente no espaço expositivo e fiz várias fotografias da obra. Cf. SPERANZINI. Aqui tem coisa. Georges Perec e a Arte Contemporânea. In: Criação \& Crítica, 2009, pp. 144-159.

${ }^{15}$ Édouard Levé (1965-2007) estava representado por uma série de retratos a cores. Chamou minha atenção o retrato de um jovem sorridente, moreno, próximo ao trabalho de Firman. (Cf. fig. 1, In: SPERANZINI. Criação \& Crítica, 2009, p. 148). Quando me aproximo e leio a legenda fixada na própria moldura do retrato: 'Yves Klein', penso: 'impossível, esse não é ele'. Ao lado, outros retratos têm como legenda: André Breton, Fernand Léger, Eugène Delacroix, Raymond Roussel... A série se chama Portraits d'homonymes [Retratos de homônimos], (1996 - 1998). Perec certamente aprovaria a 'brincadeira'. Cf. FLEURY. Édouard Levé. In: “regarde de tous tes yeux, regarde”, 2008, p. 107. 
escritor francês do pós-guerra o mais geralmente designado, citado, invocado, invejado e retomado pelos "artistas contemporâneos" de ontem e de hoje? ${ }^{16}$

Apesar de atuar na vanguarda literária do seu tempo, Georges Perec era bastante conservador nas suas preferências, se restringindo basicamente à pintura e buscando nela algo de 'funcional' ${ }^{17}$. Por algumas das suas declarações, posso entender que, para Perec, a arte interessante seria aquela que servisse a algum propósito seu, como, por exemplo:

- o de escrever (um estímulo):

Eu confirmo de imediato que absolutamente não sou crítico de arte, o que significa que eu nunca experimentei compor um discurso sobre um pintor sob o ponto de vista de sua pintura. O que eu tento fazer a partir do que eu sinto ao ver o trabalho de um artista, de um pintor ou de um fotógrafo, é que isso se traduza em algo que eu faço do ponto de vista de meu próprio trabalho. ${ }^{18}$

- o de ver o mundo com distanciamento (um filtro):

Os pintores hiper-realistas me influenciaram particularmente: por alguns quadros onde temos de repente a sensação que nossa sensibilidade com relação ao mundo despenca por completo. Nunca prestamos atenção aos objetos do cotidiano nem aos barulhos de fundo da vida. E temos subitamente por esses quadros o olhar surpreso disso que não vemos e que é colocado à luz. Isso se torna insuportável, onírico, imaginário. O real despenca no irreal. ${ }^{19}$

${ }^{16}$ [...] comment expliquer donc que ce soit lui, Georges Perec, cet auteur au fond si anachronique dans son rapport à l'art de son temps, qui soit en même temps l'écrivain français d'après-guerre le plus souvent désigné, cité, invoqué, envié et repris par les "artistes contemporains" d'hier et d'aujourd'hui? COLARD. Un cabinet d'amateurs. In: Les Inrockuptibles, 2003, p. 44.

${ }^{17}$ A obra de Perec está repleta de citações e referências a pinturas. Muitas vezes, além de servirem de exemplos de organização do espaço visual, elas também contribuiam para que ele propusesse textos que acompanhavam um exercício do olhar em vários níveis: desde o olhar do escritor sobre o real imediato a sua volta, passando pelo olhar do narrador/personagem sobre o que se queria fazer notar ao leitor, até chegar ao olhar do leitor, instigado a buscar na matéria gráfica disposta na página/tela indícios de outros/novos sentidos para o que se lia. Também é importante notar que, além da presença sistemática de pinturas em sua obra, Perec também escreveu textos que apresentavam a obra plástica (pinturas, desenhos e fotografias) de outros artistas. Sobre a relação da obra perequiana com a pintura cf., em especial: Cahiers Georges Perec no 6. L'oeil d'abord... Georges Perec et la peinture, 1996; MAGNÉ. Peinturecriture. In: Perecollages, 1989, pp. 219-229; e MOLTENI. Perec's Painterly Eye. In: The Review of Contemporary Fiction, 2009, pp. 210-223.

${ }^{18}$ Je précise tout de suite que je ne suis absolument pas critique d'art, c'est-à-dire que je n'ai jamais essayé de faire un discours sur un peintre au point de vue de sa peinture. Ce que j'essaie de faire, c'est d'essayer de faire que ce que je ressens en voyant le travail d'un artiste, d'un peintre ou d'un photographe, se traduise dans quelque chose que je fais du point de vue de mon propre travail. PEREC. Art et poésie: le livre illustré. (1981). In: . Entretiens et Conférences, 2003 b p. 330.

${ }^{19}$ Des peintres hyperréalistes m'ont particulièrement influencé: par certains tableaux où l'on a le sentiment tout à coup que notre sensibilité par rapport au monde bascule complètement. On n'a jamais fait attention aux objets de la quotidienneté ni aux bruits de fond de la vie. Et on a soudain par ces tableaux le regard étonné de ce qu'on ne voit pas et qui est mis ainsi en lumière. Cela devient insupportable, onirique, imaginaire. Le réel bascule dans l'irréel. PEREC. La vie est un livre. (1979). In: 2003b, p. 77.

Entretiens et Conférences, 
- o de criar relações (um dispositivo):

Eu tenho antes a impressão que, se um pintor influenciou meu trabalho, ele é Paul Klee, mas não sei exatamente como; acho que vem dele o fato de trabalhar por programas, e em direções cada vez um pouco diferentes. ${ }^{20}$

- o de enganar o interlocutor (um jogo):

[...] o trompe-l'œil é uma armadilha que dirige nossa atenção para nosso próprio olhar, à maneira como olhamos - e ocupamos - o espaço. [...] $\mathrm{O}$ que interrompe nosso olhar, um curto instante, é a irrupção da ficção num universo o qual, em função do que poderíamos chamar de nossa cegueira cotidiana, não sabemos mais prestar atenção. Nesse sentido, os trompe-l'œil funcionam um pouco como as palavras cruzadas: eles fazem uma pergunta cuja resposta está contida completamente no próprio enunciado que a formula [...] mas que permanece enigmática até que não operemos o deslizamento minúsculo de sentido que a resolve na sua evidência irrespondível. ${ }^{21}$

Se Perec não se empolgava exatamente pela arte contemporânea, a arte contemporânea reconhece muitos valores na obra perequiana e foi por esse ponto de vista que prossegui com a pesquisa. O ponto de conexão entre esses dois universos distintos se dá especialmente pelo interesse pelas 'coisas' e pela maneira como elas são agregadas e significadas, indicando sempre ao interlocutor que, para todo cheio, há também, na mesma medida, um vazio, e que cabe a ele avaliar e decidir o que está valendo.

Mas para continuar a expor o que se pretende com a aproximação da obra perequiana com a Arte Contemporânea, é necessário antes fazer alguns esclarecimentos sobre o que se entende aqui por 'arte contemporânea'. É mais ou menos consensual que o que deflagra o movimento da Arte Contemporânea na França ocorre no final dos anos cinquenta e início dos anos sessenta através do surgimento de uma nova geração de artistas com uma produção que indicava o esgotamento da experiência moderna ${ }^{22}$. Um dos primeiros eventos importantes que ocorrem na França e onde se identifica uma série de iniciativas artísticas heterogêneas como 'arte contemporânea', ocorreu em 1972 com a exposição apresentada no Grand Palais:

${ }^{20}$ J'ai plutôt l'impression que si un peintre a influencé mon travail, c'est Paul Klee, mais je ne sais pas exactement comment; il me semble que c'est de lui que me vient le fait de travailler sur programme, et dans des directions chaque fois légèrement différentes. LE SIDANER. Entretien avec Georges Perec. (1979). In: L'Arc, 2005, p. 31.

${ }^{21}[. .$.$] le trompe-l'œeil n'est qu'un piège qui nous renvoie à notre regard, à la manière dont nous regardons - et$ occupons - l'espace. [...] Ce qui arrête notre regard, un court instant, c'est l'irruption de la fiction dans un univers auquel, à cause de ce que l'on pourrait appeler notre cécité quotidienne, nous ne savons plus prêter attention. En ce sens, les trompe-l'œil fonctionnent un peu comme les mots croisés: ils posent une question dont la réponse est tout entière contenue dans l'énoncé qui la formule [...] mais qui demeure énigmatique tant que l'on n'a pas opéré le minuscule glissement de sens qui la résoud (sic) dans son évidence imparable. PEREC; WHITE. L'ail ébloui, 1987, s/ nº p.

${ }^{22}$ Entre as várias iniciativas nesse sentido, destaco o surgimento em 1960 do Nouveau Réalisme, movimento artístico encabeçado por Pierre Restany que tratarei no item 1.3.. 
Douze ans d'art contemporain en France: 1960-1972 ${ }^{23}$ [Doze anos de arte contemporânea na França: 1960-1972]. Em vários dos textos críticos presentes no catálogo da exposição há a indicação de que, desde o início dos anos sessenta, muitos autores designavam como 'arte contemporânea' a produção de artistas jovens que, mesmo sem apresentar um interesse e/ou linguagem comum, discutia questões atuais da sociedade francesa por meios e formas que também desafiavam o estatuto da arte vigente. 'Arte contemporânea' identificava então menos um período temporal, um gênero ou um tipo de suporte/técnica/procedimento e mais a atitude de enfrentamento e questionamento da produção de alguns artistas em vias de se fazer reconhecer.

Couturier, num livro que pretende introduzir as problemáticas principais que envolvem o universo complexo da Arte Contemporânea: L'Art Contemporain mode d'emploi [A Arte Contemporânea manual de instruções] (e que traz no próprio título uma referência perequiana importante ${ }^{24}$ ), indica que é a diversidade, a mobilidade e a auto-transformação constante dos parâmetros que marcam esse campo da arte que garantem a longevidade do termo e nossa dificuldade em delimitá-lo. Para essa autora:

[...] a arte contemporânea esgota constantemente suas próprias definições... Transformada em um gênero em si, ela engloba contudo uma grande quantidade de obras que estabelecem um mesmo estado de espírito: a arte contemporânea inventa práticas, explora novos territórios ou reinventa fórmulas já testadas. Breve, ela se reposiciona constantemente. Estão excluídas do clube as obras que repetem as formas do passado, a não ser que seja uma citação intencional. Distanciamento e segundo grau asseguram assim a continuidade..$^{25}$

Além de uma grande variedade de propostas e interesses, é importante saber que a Arte Contemporânea, surgida nos anos sessenta, chega até nós sem estar restrita a um espaço ou a um período temporal determinados, pois, como escreve Agamben $^{26}$ :

é verdadeiramente contemporâneo, aquele que não coincide perfeitamente com este, nem está adequado às suas pretensões e é, portanto, nesse sentido, inatual; mas,

\footnotetext{
${ }^{23}$ Douze ans d'art contemporain en France: 1960-1972. Catálogo da Exposição, 1972.

${ }^{24}$ É inevitável a relação desse título com o livro mais famoso de Perec: La Vie mode d'emploi.

${ }^{25}$ [...] l'art contemporain épuise constamment ses propres définitions... Devenu un genre en soi, il englobe cependant une grande quantité d'œuvres qui relèvent d'un même état d'esprit : l'art contemporain invente des pratiques, explore de nouveaux territoires ou réinvente des formules déjà eprouvées. Bref, il se repositionne en permanence. Sont exclues du club les oeuvre qui répétent les formes du passé, sauf si c'est une citation intentionnelle. Distanciation et second degré prennent alors le relais. COUTURIER. L'Art Contemporain mode d'emploi, 2004, p. 18.
}

${ }^{26}$ AGAMBEN. $\underline{O}$ que é o contemporâneo. In: 58-59. O que é o contemporâneo? E outros ensaios, 2009, pp. 
exatamente por isso, exatamente através desse deslocamento e desse anacronismo, ele é capaz, mais do que os outros, de perceber e apreender o seu tempo.

É principalmente por essa capacidade de 'perceber e apreender seu tempo' que eu pretendo aproximar e por em diálogo a obra de Perec com a de três artistas: Arman, Joe Brainard e Édouard Levé. Com interesses, motivações, contextos e fazendo uso de procedimentos/estratégias tão distintos, esses quatro produtores guardam em comum um mesmo tipo de impulso: o do artista contemporâneo, identificado assim por Couturier:

O artista contemporâneo redefine as evidências, responde a expectativas inexprimidas, perturba as convenções, desloca os pontos de vista. Ele nos estende um espelho, sonda nossos desejos, capta os não-ditos, projeta um futuro ainda imperceptível. $^{27}$

O que apresento a seguir não acompanha qualquer cronologia ou outro tipo de linearidade: em cada um dos três capítulos da tese trago uma obra do escritor Georges Perec para dialogar com a(s) obra(s) de Arman, Joe Brainard e Édouard Levé. Para isso localizo de início estruturas, interesses e procedimentos que têm paralelismos na maneira como eles buscaram no real concreto o material bruto para suas iniciativas artísticas. Ainda que, em vários momentos, existam semelhanças entre eles, não cabe aqui pensar em qualquer tipo de influência, descendência e ou consequência, mas em aproximações, convergências e referências. Também entendi como necessário que, ao longo da tese, se quebrasse o discurso restrito das obras estudadas e uma ideia de narrativa contínua, fragmentando e trazendo para a pesquisa referências e/ou procedimentos de outros autores/obras, além de trechos mais longos de traduções da obra perequiana, para ampliar a compreensão de particularidades e/ou potencialidades dos diálogos propostos: ainda que não se tratasse da obra perequiana, a aproximação com a Arte Contemporânea é por princípio tateante e plural e a indicação de algumas aberturas e/ou anexos me pareceram inevitáveis.

Quanto à estrutura propriamente dita da tese, no capítulo 1, abordo o primeiro livro de Perec Les choses, une histoire des années soixante ${ }^{28}$ [As coisas, uma história dos anos

\footnotetext{
${ }^{27}$ L'artiste contemporain redéfinit les évidences, répond à des attentes inexprimées, perturbe les conventions, déplace les points de vue. Il nous tend un miroir, sonde nos désirs, capte les non-dits, projette un devenir enconre imperceptible. COUTURIER. L'Art Contemporain mode d'emploi, 2004, p. 20.
}

Para um estudo mais amplo e aprofundado sobre o assunto, cf. também: ARDENNE. Art. L'Âge Contemporain, 2003.

${ }^{28}$ PEREC. Les choses, une histoire des années soixante, 2002. 
sessenta] -, livro que teve uma única edição no Brasil no final dos anos sessenta ${ }^{29}$, mas que nunca deixou de ser reeditado na França desde seu lançamento em 1965. O universo principal do livro é a sociedade de consumo e um exercício compulsivo da acumulação que valoriza o 'sempre mais'. Como todo início de pesquisa, devo apresentar ao leitor o que diferencia o universo das coisas daquele dos objetos e como se dão as relações do indivíduo com elas. Não avanço em qualquer análise sociológica e/ou filosófica porque isso representaria novos caminhos por onde a obra perequiana, certamente, poderia se expandir e diversificar.

Para tratar do que há de descontrolado na relação com o objeto de consumo nas artes visuais, recorro à série das acumulações de Arman, membro fundador do Nouveau Réalisme, que, com seus trabalhos, mostra o que acontece com o objeto quando se esgotam suas possibilidades de serventia e fantasia e ele deixa de ser atraente ao usuário: pura materialidade estéril.

No segundo capítulo é a vez de abordar o cotidiano urbano indistinto, suas ações repetitivas, a construção alucinada de séries intermináveis e o barulho de fundo da vida de todo dia. $\mathrm{O}$ indivíduo perde o interesse pela acumulação indistinta das coisas e passa a preservá-las de maneira mais organizada e selecionada, compondo assim suas coleções. Enquanto nos Estados Unidos, Joe Brainard, misto de artista plástico e escritor, recolhia das ruas 'pedaços de real' para suas colagens Pop e 'pedaços de memória' para sua coleção de lembranças contidas em I remember ${ }^{30}$ [Eu me lembro], Perec, na França, aprendia com o OuLiPo a criar rotinas de escrever que ele rapidamente transformaria em rotinas de viver. Ele, que se lembrava muito pouco da infância triste, se limitaria em Je me souviens (Les choses communes I) ${ }^{31}[\mathrm{Eu}$ me lembro, As coisas comuns I] a recolher o desinteressante e o desimportante de uma memória coletiva, antes que tudo fosse levado de vez pelo esquecimento.

No terceiro e último capítulo, é o exercício da ideia e do programa que passam a direcionar os movimentos do artista e é nesse momento que a produção perequiana se confunde em forma e em procedimentos com a chamada Arte Conceitual. Agora, tudo o que o homem toma do mundo e acredita ser importante preservar, ele designa como 'documento' e preserva num 'arquivo'. Todo esse material de significado pontual, deve ficar à espera de um interlocutor interessado que venha ali pesquisar e relacionar os documentos para, então,

\footnotetext{
${ }^{29}$ PEREC. As coisas, uma história dos anos sessenta, 1969.

${ }^{30}$ BRAINARD. I remember, 2006.

31 PEREC. Je me souviens (Les choses communes I), 2004a.
} 
compor algum sentido. Perec iniciou um projeto de escrita que deveria ocupá-lo por doze anos, mas que foi abandonado pela metade. Édouard Levé, artista de muitos interesses, decidiu se antecipar e descrever em Euvres ${ }^{32}$ [Obras] todas as obras de arte que ele planejava algum dia realizar - projeto esse interrompido no dia que o artista desistiu de continuar a viver. Como exemplo do que seria possível fazer a partir dos seus arquivos, Perec foi três dias seguidos até a Place Saint-Sulpice em Paris para tomar nota "do que acontece quando não acontece nada" e com isso escrever Tentative d'épuisement d'un lieu parisien ${ }^{33}$ [Tentativa de esgotamento de um lugar parisiense ${ }^{34}$ um exercício de descrição exaustiva que lhe permitisse "descrever o resto", aquilo que ninguém nunca reparou. Já, Levé, realizaria umas das obras contidas em Oeuvres, viajaria até uma cidadezinha no interior da França para compreender e ver de perto o que significava reconhecer em tudo, em todos e por toda parte o peso de pertencer a um lugar chamado Angoisse [Angústia].

Cada uma das três formas de agrupamento das coisas, pela acumulação, pela coleção e pelo arquivo, indica um tipo de organização do mundo. Nesta tese, a partir dos textos de Perec e com o apoio das obras de três artistas visuais, procurarei indicar o que configura o mundo 'segundo G.P.' - um mundo que ultrapassou o tempo do autor e que agora, por outras obras, outras mãos e outras mentes continua sendo constantemente refeito.

Por irritante que ela seja - e excitante, ao mesmo tempo -, a insuficiência conceitual da definição do artista contemporâneo não é menos reveladora: o artista contemporâneo, realmente, não é um, mas vários. [...] Um multitipo. ${ }^{35}$

Paul Ardenne

\footnotetext{
${ }^{32}$ LEVÉ. CEvres, 2002.

${ }^{33}$ PEREC. Tentative d'épuisement d'un lieu parisien, 2008.

${ }^{34}$ A única tradução para o português dessa obra de Perec foi feita durante os anos setenta em Portugal, fazendo parte de uma coletânea de textos da revista Cause commune. Cf. PEREC. Leitura exaustiva de um lugar parisiense - ou as ruínas de Paris. In: Grupo Cause commune. O apodrecimento das Sociedades, 1977, pp. 39-65.

${ }^{35}$ Pour irritante qu'elle soit - et excitante, du même coup -, l'insuffisance conceptuelle de la définition de l'artiste contemporain n'en est pas moins révélatrice: l'artiste contemporain, bel et bien, n'est pas un mais plusieurs. [...] Un multitype. ARDENNE. L'Artiste à l'Âge Contemporain: un acteur protéiforme. In: . Art. L'Âge Contemporain, 2003, p. 24.
} 


\title{
1. A acumulação, ou, o que só aumenta
}

\subsection{Você é feliz?}

\begin{abstract}
E durante quatro anos, talvez mais, eles exploraram, entrevistaram, analisaram. Por que os aspiradores com rodinhas vendem mal? O que pensam, nas classes mais baixas, do radicchio? Gostam do purê pronto, e por quê? Porque é leve? Porque é cremoso? Porque é fácil de fazer: um gesto e ôpa? Acredita-se mesmo que os carrinhos de criança são caros? Não se está sempre disposto a um sacrifício pelo conforto dos pequenos? Como votará a francesa? Gostam do queijo em bisnaga? Estão a favor ou contra o transporte coletivo? O que mais chama a atenção ao tomar um iogurte: sua cor? sua consistência? seu sabor? seu aroma natural? Você lê muito, um pouco, ou nada? [...] O que acha da sua máquina da lavar? Está satisfeito com ela? Ela não faz muita espuma? Ela lava bem? Ela rasga a roupa? Ela seca a roupa? Você não preferiria uma máquina de lavar que também secasse sua roupa? [...]

Nada do que era humano lhes foi estranho. ${ }^{36}$ (Lc, pp. 33-34).
\end{abstract}

Entre as várias perguntas suscitadas pela leitura do primeiro livro publicado por Georges Perec - Les choses, une histoire des années soixante [As coisas, uma história dos anos sessenta] -, uma das mais potentes é aquela que incita o leitor a pensar sobre o seu próprio estatuto de felicidade e a relação disso com a riqueza, a vida doméstica e o conforto material. Difícil não se sentir provocado pela afirmação de que a felicidade está ligada diretamente aos bens materiais e que, mesmo estando à disposição da maioria, a felicidade só se efetiva nas mãos de poucos. O leitor assim é levado a se perguntar: de que lado estou? Do lado de muitos ou do lado de poucos?

A história contada por Perec se concentra nos valores sociais e culturais que contribuíam para definir a maneira como um casal de jovens franceses, no início dos anos sessenta, se esforçava por construir uma rotina de vida em que fosse possível trabalhar pouco, ganhar muito e ter tempo de sobra para usufruir das facilidades propostas por uma nova

${ }^{36}$ Et pendant quatre ans, peut-être plus, ils explorèrent, interviewèrent, analysèrent. Pourquoi les aspirateurstraîneaux se vendent-ils si mal? Que pense-t-on, dans les milieux de modeste extraction, de la chicorée? Aime-t-on la purée toute faite, et pourquoi? Parce qu'elle est légère? Parce qu'elle est onctueuse? Parce qu'elle est si facile à faire: un geste et hop? Trouve-t-on vraiment que les voitures d'enfants sont chères? N'est-on pas toujours prêt à faire un sacrifice pour le confort des petits? Comment votera la Française? Aime-t-on le fromage en tube? Est-on pour ou contre les transports en commun? A quoi fait-on d'abord attention en mangeant un yaourt: à la couleur? à la consistance? au goût? au parfum naturel? Lisez-vous beaucoup, un peu, pas du tout? [...] Que pensez-vous de votre machine à laver? Est-ce que vous en êtes satisfaite? Est-ce qu'elle ne mousse pas trop? Est-ce qu'elle lave bien? Est-ce qu'elle déchire le linge? Estce qu'elle sèche le linge? Est-ce que vous préféreriez une machine à laver qui sècherait votre linge aussi? [...] / Rien de ce qui était humain ne leur fut étranger. 
sociedade que se reorganizava após o desastre da Segunda Grande Guerra. Infelizmente, para esses jovens bombardeados por imagens de sucesso, conforto e felicidade - mitos construídos e lançados pela publicidade que vinha a reboque da indústria de massa -, 'querer' simplesmente não era o suficiente para 'ter', como explicaria o próprio Perec em uma entrevista:

É que há, eu penso, entre as coisas do mundo moderno e o bem-estar, uma relação obrigatória. [...] Mas esse bem-estar comporta um possível; visto que, na nossa sociedade capitalista, é: coisas prometidas não são coisas devidas. Prometem-nos tudo, enfim, a publicidade nos incita a tudo, a ter tudo, a possuir tudo, a gozar tudo; e não temos nada, ou temos um monte de coisinhas, temos alegriazinhas. ${ }^{37}$

Com esse livro, Perec trazia para a literatura um novo tipo de objeto - um objeto do cotidiano acoplado a um 'modo de vida' ainda estranho à maioria dos franceses - que, antes de configurar uma determinada funcionalidade, designava um território ambíguo de desejos e fantasias que passaria, cada vez mais, a ocupar um espaço não só na literatura como em todas as artes interessadas em explorar, discutir e destacar as questões do seu tempo.

Pelo menos dez anos antes da publicação de Les choses, os objetos já haviam adquirido um destaque na literatura através do Nouveau Roman - denominação dada à produção de um grupo de jovens autores que, por interesses e procedimentos diversos, buscavam renovar esse gênero literário. Segundo Roland Barthes, eles traziam um novo tipo de questionamento para a literatura:

\footnotetext{
"As coisas significam alguma coisa?"

Até então, a literatura nunca tinha colocado em dúvida o sentido das coisas. Isso quer dizer, nesse caso, a totalidade do que nos cerca, tanto um acontecimento como um objeto. A literatura tem, portanto por papel fazer esse questionamento, fazêlo através da narrativa, do romanesco, do personagem ou do objeto. ${ }^{38}$
}

${ }^{37}$ C'est qu'il y a, je pense, entre les choses du monde moderne et le bonheur, un rapport obligé. [...] Mais ce bonheur demeure un possible; car, dans notre société capitaliste, c'est: choses promises ne sont pas choses dues. On nous promet tout, enfin, la publicité nous engage à tout, à tout avoir, à tout posséder, à jouir de tout; et nous n'avons rien, ou nous avons de toutes petites choses, nous avons de tout petits bonheurs. PEREC. Le bonheur est un processus... on ne peut pas s'arrêter d'être heureux. (1965). In: Entretiens et Conférences, 2003a, p. 46.

38 “Est-ce que les choses signifient quelque chose?” / Jusqu'alors, la littérature n'avait jamais mis en doute le ses des choses. Cela veut dire, dans ce cas, la totalité de ce qui nous entoure, un événement aussi bien qu'un objet. La littérature a don pour rôle de poser cette question, de la poser u travers du récit, du romanesque, du personnage ou de l'objet. BARTHES. Les choses signifient-elles quelque chose? (1962). In: Euvres Complètes, 2002b, p. 46. 
O objeto seria então o ponto de partida para muitos dos questionamentos na obra de Alain Robbe-Grillet - definida como 'coisista ${ }^{39}$ por Roland Barthes. O crítico entendia que o 'objeto novo' trabalhado por Robbe-Grillet era o mesmo objeto com o qual os indivíduos desenvolviam suas atividades no cotidiano comum, mas que agora surgiam na literatura de um modo diferente ao que se fizera até então. Segundo Barthes: "O NR [Nouveau Roman] tentou, portanto ver os objetos desprovidos dos seus significados correntes. Robbe-Grillet trouxe ao objeto uma luz nova. Ele o mostrou sem lembranças, sem poesia. É uma descrição opaca $[\ldots] . ", 40$

Acompanhando o que ocorria na vanguarda literária, também nas artes visuais os objetos receberiam um grande destaque no final dos nos cinquenta através de um movimento que também se identificava com o 'novo', era o Nouveau Réalisme. Esse movimento era encabeçado pelo crítico Pierre Restany e tinha em Arman um dos expoentes. Por meio de procedimentos acumulativos, Arman se apropriava do objeto banal do cotidiano para compor e enfatizar o que Restany chamava de um 'fenômeno quantitativo' 41.

Esse mesmo fenômeno está presente no livro de Perec onde as coisas vão indicar um novo momento na relação do homem com os objetos e, nas palavras do próprio Perec: "uma mutação se produz, onde o conforto se torna arte de viver, ideal de vida, onde o ter se torna modelo de ser, onde a acumulação se torna um modo de vida exemplar" ${ }^{42}$.

Ainda que nas obras de Arman e de Perec - como será visto a seguir -, existam proposições díspares quanto ao trabalho com o objeto, os dois artistas iniciantes recorreram ao exercício da acumulação para se aproximar do coletivo e questionar o lugar da felicidade numa sociedade que, recém-saída de um desastre mundial, prometia opulência e

${ }^{39}$ Roland Barthes reconhecia dois momentos na obra de Robbe-Grillet publicada até o início dos anos sessenta: no primeiro, tratava-se da obra de um Robbe-Grillet 'coisista', na qual os objetos se apresentam de maneira imediata a marcar uma simples presença e sem agregar qualquer outro valor e/ou sentido à história; já, no segundo momento, tratava-se da obra de um Robbe-Grillet 'humanista', que era quando os objetos teriam uma função mediadora e que, mesmo sem serem exatamente símbolos, ainda assim seriam indicadores de outra coisa. Cf. BARTHES. Le point sur Robbe-Grillet? (1963). In: Euvres complètes, 2002b, pp. 454-455.

${ }^{40}$ Le NR [Nouveau Roman] a donc essayé de voir les objets dépourvus de leur signification courante. RobbeGrillet a apporté à l'objet un éclairage nouveau. Il l'a montré sans souvenirs, sans poésie. C'est une description mate [...]. BARTHES. Les choses signifient-elles quelque chose? (1962). In: . Euvres Complètes, 2002 b, p. 46.

${ }^{41}$ Cf. RESTANY. O Novo Realismo. In: Os novos realistas, 1979 , p. 30.

${ }^{42}$ [...] une mutation se produit, ou le confort devient art de vivre, idéal de vie, où l'avoir devient modèle d'être, où l'accumulation devient un genre de vie exemplaire. PEREC. Le bonheur est un processus... on ne peut pas s'arrêter d'être heureux. (1965). In: Entretiens et Conférences, 2003a, p. 47. 
oportunidades em grande escala, já que, como afirma Perec: “A felicidade é um processo que é, no final das contas, a mesma coisa que a acumulação: não podemos parar de ser felizes." 43

Quando surge a obra de Perec, os questionamentos acerca das coisas na literatura pareciam já ter sido todos feitos nos artigos de Roland Barthes:

[...] as coisas são indutoras de sentido, ou então o contrário, são “opacas”? O escritor pode e deve descrever um objeto sem direcioná-lo a alguma transcendência humana? Significantes ou insignificantes, qual é a função dos objetos em uma narrativa romanesca? Em quê, a maneira pela qual os descrevemos, modifica o sentido da história? a consistência do personagem? a própria relação com a ideia de literatura? ${ }^{44}$

Não era bem assim e ainda existiriam muitas perguntas sem resposta.

\subsubsection{Que coisa é essa?}

As coisas - a parte do humano investida e protegida pelos objetos - sempre foram o grande tema de Perec. ${ }^{45}$

Ítalo Calvino

Les choses, une histoire des années soixante marca a estreia de Georges Perec na literatura. Publicado em 1965, recebeu no mesmo ano o Prêmio Renaudot. Seu título é pura ambiguidade: ao mesmo tempo em que 'as coisas' não particularizam nada, indicam tudo. No início, quando Perec começava a escrever seu livro, pensava chamá-lo 'La Grande Aventure' [A grande aventura], depois pensou em 'Histoire d'un couple' [História de um casal], 'Objets' [Objetos] e, por fim, 'Choses' [Coisas] ${ }^{46}$. Essas várias mudanças de título podem ser

${ }^{43}$ Le bonheur est un processus qui est, en fin de compte, la même chose que l'accumulation: on ne peut pas s'arrêter d'être heureux. PEREC. Le bonheur est un processus... on ne peut pas s'arrêter d'être heureux. (1965). In: Entretiens et Conférences, 2003a, p. 47.

44 [...] les choses sont-elles inductrices de sens, ou bien au contraire sont-elles "mates"? L'écrivain peut-il et doit-il décrire un objet sans le renvoyer à quelque transcendance humaine? Signifiants ou insignifiants, quelle est la fonction des objets dans un récit romanesque? En quoi la façon dont on les décrit modifie-t-elle le sens de l'histoire? la consistance du personnage? le rapport même à l'idée de littérature? BARTHES. Le point sur Robbe-Grillet? (1962). In: Cuvres complètes, 2002b, p. 452.

${ }^{45}$ Le cose - la parte d'umano investita e custodita dagli oggetti - sono sempre state il grande tema di Perec. CALVINO. Perec e il salto del Cavallo. (1984). In: BORSARI. Georges Perec, 1993, p. 137.

${ }^{46}$ Cf. PEREC. Georges Perec: "J'utilise mon malaise pour inquiéter mes lecteurs". (1969). In: Entretiens et Conférences, 2003a, p. 107. 
entendidas como um processo de enquadramento daquilo que configuraria seu interesse maior e que ultrapassaria o âmbito desse primeiro livro: no início a atenção se localizava na ação, na fábula que se queria contar, fórmula mais próxima da narrativa tradicional; passava então para os agentes dessa ação, os personagens; e se voltava para os marcos/obstáculos que haviam demarcado/acompanhado o que se passou, os objetos; até chegar num plano que incorporava todas as instâncias anteriores, deixando ainda espaço para outras possibilidades mais abrangentes que ainda poderiam surgir.

A preocupação com 'coisas' não era nova para Perec e no rascunho de uma narrativa que ele escrevia em 1962: Le Portulan [O Portulano], ele colocava na fala de um personagem e na forma de digressões, várias inquietações sobre as coisas:

Eu gostaria de saber bem. Compreender. As coisas. O espírito das coisas, o fim do fim, o espírito das formas. Os acontecimentos, as ideias, os homens. Eu. Eu do início. Eu Mathieu.[...]

Há em primeiro lugar o tempo, a hora, o lugar. Todas essas coisas ao meu redor, das quais algumas são rostos, mas não o sabemos, nos esquecemos muito facilmente sem mesmo nos darmos conta. Esses rostos idiotas e satisfeitos. Os belos sapatos, as gravatas de seda, as camisas impecáveis, os sorrisos abertos [...].

[...] Chamamos as coisas de coisas porque não sabemos como chamá-las de outro modo, as relações entre as pessoas, as atitudes, as forças, as recusas, os entusiasmos, os defeitos, as vitórias, os foras, as falsas vitórias, as idéias, os fenômenos, as coisas. ${ }^{47}$

Se nesse momento Perec assinalava a inquietação do personagem com relação às coisas, dias depois ele imputaria ao personagem questionamentos que, como salienta Hans Hartje, ganhariam uma nova dimensão anos depois ${ }^{48}$ :

Parece que me faço uma pergunta muito simples: como olhar? Como [...] começar a ver nas coisas outra coisa que não o que me habituaram a ver. [...] Existem tantas e tantas coisas que fazemos a cada dia e das quais o homem nunca se deu conta. Elas nos parecem naturais, mas elas não o são. Elas correspondem a alguma

${ }^{47}$ Je voudrais bien savoir. Comprendre. Les choses. L'esprit des choses, le fin du (sic) fin, l'esprit des formes. Les événements, les idées, les hommes. Moi. Moi d'abord. Moi Mathieu. [...] / Il y a d'abord le temps, l'heure, le lieu. Toutes ces choses autour de moi, dont certaines sont des visages, mais on ne le sait pas, on l'oublie trop facilement, on ne s'en rend pas compte. Ces visages abrutis et satisfaits. Les belles chaussures, les cravates en soie, les chemises impeccables, les sourires ouverts [...]. I On appelle les choses les choses parce qu'on ne sait pas comment les appeler autrement, les rapports entre les gens, les attitudes, les forces, les refus, les enthousiasmes, les défaites, les victoires, les demi-échecs, les fausses victoires, les idées, les phénomènes, les choses. PEREC. Datiloscrito $\mathrm{f}^{\circ}$ 119.21.28.2. intitulado 'le portulan' e datado de 01/04/1962. Apud HARTJE. Georges Perec écrivant, 1995, p. 40.

${ }^{48}$ Uma dúzia de anos depois, Perec retomaria esses questionamentos - tidos como de preocupações de ordem sociológica - tanto no editorial Approches de quoi? [Aproximações de quê?] (1973) escrito para a revista Cause Commune, como também no livro Espèces d'espaces [Espécies de espaço] (1974), da coleção Espace Critique, [Espaço Crítico] dirigida por Paul Virilio. Tratarei do editorial no próximo capítulo e abordarei alguns aspectos do livro no terceiro capítulo. 
coisa que não conseguimos pegar ou, muito dificilmente, com fugas, álibis, falsas desculpas. As coisas sendo isso que são, dizem, mas as coisas nunca são assim, sobra uma margem. ${ }^{49}$

Entre os vários questionamentos do personagem já era possível reconhecer algumas características que marcariam a futura obra perequiana como, por exemplo:

- a inclusão mascarada na escrita de referências tiradas da sua vida pessoal e cotidiana, compondo assim uma forma oblíqua de escrita autobiográfica já que, transladadas para a narrativa, essas referências se desligavam da vida do autor para servir à escrita ${ }^{50}$;

- a importância do olhar como sentido de contato com o mundo da realidade concreta e que, num determinado momento, vai levar o leitor a tomar consciência da própria escrita como matéria significativa;

- e a busca por estratégias de aproximação no campo das ações e presenças do cotidiano como, por exemplo, o exercício do espaço, o qual, mesmo evidente, ainda assim é invisível a qualquer iniciativa objetiva.

Agora, antes de continuar tratando de coisas e objetos que, junto com espaços e lugares, têm presença marcante na obra de Perec e serão elos importantes entre a sua obra e a produção artística contemporânea, é necessário explicitar o que diferencia o objeto da coisa.

${ }^{49}$ Il me semble que je me pose une question très simple: comment regarder ? Comment [...] commencer de voir dans les choses autre chose que ce que l'on m'a habitué à voir. [...] Il y a tant et tant de choses que nous faisons chaque jour et que l'homme n'a jamais fait de toute éternité. Elles nous semblent naturelles, mais elles ne le sont pas. Elles correspondent à quelque chose que nous n'arrivons pas à saisir, ou bien malaisément, avec des fuites, des alibis, des fausses excuses. Les choses étant ce qu'elles sont, dit-on, mais les choses ne sont jamais ainsi, il reste une marge. PEREC. Datiloscrito $\mathrm{f}^{\circ}$ 119.21.28.5. intitulado 'le portulan' e datado de 08/04/1962. Apud HARTJE. Georges Perec écrivant, 1995, p. 40.

${ }^{50}$ No caso particular de Le Portulan isso ocorre com o objeto que dá título ao livro e que vai reaparecer em várias outras obras do autor (por ex., em Les choses): o portulano - tipo de carta marinha que indica a localização de acidentes geográficos, cidades e portos ao longo da costa. Até o fim da vida, Perec manteve ao lado de sua mesa de trabalho a cópia de um portulano dado a ele de presente por uma prima. Cf. BELLOS. Georges Perec, 1994, p. 111. 


\title{
1.1.2. A coisa e o objeto
}

\begin{abstract}
Que é uma coisa? Há quanto tempo o homem já refletiu e perguntou pela coisa? Quantas vezes e de quantas formas o homem já usou e abusou da coisa? Com quanta profundidade já explicou as coisas, de acordo com seus propósitos, e explicou, no sentido de reconduzi-las às suas causas? De há muito, o homem lida e continua sempre a lidar com as coisas, sem, no entanto, pensar, uma vez sequer, a coisa, como coisa!
\end{abstract}

Martin Heidegger ${ }^{51}$

A pergunta 'que é uma coisa?' soa tola e desnecessária, mas aqui é inevitável. Muitos já se fizeram essa pergunta e a resposta que encontraram parece não ter sido exatamente satisfatória porque a dúvida persiste e todos aqueles que, por algum motivo, passam a se referir às coisas, são levados a se questionar: que coisa é essa?

O filósofo Martin Heidegger é um pensador que trata desse questionamento em vários momentos dos seus escritos. Para ele, a pergunta 'que é uma coisa?' é do domínio das questões fundamentais da metafísica e, mesmo que muitos autores tenham tratado de respondê-la, a novidade da pergunta é a necessidade dela ser continuamente posta. Em 'A coisa e a obra', Heidegger ${ }^{52}$ afirma que "tudo é uma coisa" e que "as respostas à pergunta acerca do que a coisa é são de tal forma familiares, que não se suspeita por detrás nada que mereça ser indagado".

O que vale a pena aqui ressaltar sobre a 'coisa' é que, mesmo fazendo parte de um conhecimento comum das pessoas no qual a coisa é o que é sabido por todos, ainda assim ela está sujeita a muitos questionamentos. Como ponto de partida à pergunta 'o que é uma coisa?', busco no dicionário sua definição primeira para afirmar que a coisa é um incerto generalizante e ambíguo do que, mesmo percebido como real e servindo para identificar uma série infinita de corpos, impressões e assuntos, não comporta nada de particular, podendo tanto ser tudo quanto nada ${ }^{53}$.

Aquilo que encontramos a nossa volta no cotidiano ou são as coisas da Natureza ou são as coisas do uso. Quando nos referimos às primeiras, como, por exemplo, a uma pedra ou a um pedaço de madeira, tratamos de coisas no estado mais puro, coisas propriamente ditas, coisas que são só coisas. Já, as coisas do uso são uma matéria enformada, resultado de

\footnotetext{
${ }^{51}$ HEIDEGGER. A coisa. In: Ensaios e conferências, 2006, p. 144.

52 HEIDEGGER. A coisa e a obra. In: A origem da obra de arte, 2004, p. 15.

${ }^{53}$ COISA: é "tudo quanto existe ou possa existir, de natureza corpórea ou incorpórea", podendo também ser "algo que não se quer ou não se pode nomear", e que tem sua etimologia no latim: causa, significando “causa, razão, motivo, origem”. HOUAISS. Dicionário Eletrônico, 2009.
} 
fabricação humana e que têm por característica primordial a estabilidade da matéria - aquilo que faz com que elas possam continuar sendo a mesma coisa.

Ainda que Bill Brown, em sua Thing theory ${ }^{54}$ [Teoria da coisa], diga que "meras coisas' propõem um problema pela falta de especificidade que denotam, no caso da obra perequiana - repleta da palavra 'coisas' - isso parece abrir um campo de possibilidades a novos sentidos e relações a tudo que, designado como matéria de interesse, não tem, ou parece ainda não ter, algum sentido.

Sobre a diferença entre interagir com objetos e com coisas, Bill Brown afirma: "nós olhamos através dos objetos porque existem códigos pelos quais nossa atenção interpretativa faz deles significativos, porque existe um discurso de objetividade que nos permite usá-los como fatos. Uma coisa, em contraste, mal pode funcionar como uma janela." 55

Em comparação à 'coisa', o 'objeto' é o que se contrapõe à mera coisa (produto da natureza) e que, segundo Moles ${ }^{56}$, tem por características: a dimensão humana, ser passível de manipulação e posse, ser independente do corpo do homem e ser móvel e submisso às suas vontades ${ }^{57}$. Outro elemento que amplia a compreensão teórica do objeto é também dado por Moles em outra obra: "o objeto desafia o tempo, ele se apresenta como o que se opõe à fuga do tempo, o que estabelece a solidez do espaço e por isso abole o tempo." ${ }^{58}$ Como uma âncora ou um marco, é algo de sólido que garante um mínimo de constância em oposição ao "fluxo de seres e pensamentos". Objeto algum tem a dimensão do eterno ou do infinito, mas traz como parte do seu estatuto material a garantia de alguma permanência, alguma solidez e alguma certeza.

Se for certo que, no cotidiano, a palavra 'coisa' designa algo de concreto, ainda que impreciso, ela também serve para indicar o que ainda não tem nome ou que, se algum dia teve, agora se perdeu. O importante é saber que essa palavra sempre se refere a uma aproximação ou, como escreve Bill Brown: “'coisas' é uma palavra que tende, especialmente no seu mais banal, indicar certo limite ou liminaridade, pairar sobre o limiar entre o

\footnotetext{
${ }^{54}$ BROWN. Thing Theory. In: Things, 2004, pp. 1-17.

${ }^{55}$ We look through objects because there are codes by which our interpretive attention makes them meaningful, because there is a discourse of objectivity that allows us to use them as facts. A thing, in contrast, can hardly function as a window. Ibidem, p. 4.

${ }^{56}$ MOLES. Objet et communication. In: Communications, 1969, p. 5.

${ }^{57}$ OBJETO: do latim objectus, significa a "ação de pôr diante, obstáculo". HOUAISS. Dicionário Eletrônico, 2009.

${ }^{58}$ L'objet défie le temps, il se présente comme ce qui s'oppose à la fuite du temps, ce qui établit la solidité de l'espace et par là abolit le temps. MOLES. Théorie des objets, 1972, p. 101.
} 
nominável e o inominável, o figurável e o infigurável, o identificável e o que não se pode identificar [...]" ${ }^{59}$. O mesmo Brown sugere então que as coisas poderiam ser imaginadas como aquilo que é 'pré' e 'pós' à configuração de qualquer materialidade, tanto na forma de um conceito, como na forma de uma composição física: "Temporalizada como o antes e o depois do objeto, a coisidade equivale a uma latência (o ainda não formado ou o ainda não formável) e a um excesso (o que permanece fisicamente ou metafisicamente irreduzível a objetos)." 60

O que Bill Brown indica é um campo de ações que agem em torno do objeto e que interferem nos seus limites, na clareza da sua forma, na densidade do seu conteúdo, nas características que permitem ao indivíduo reconhecê-lo como um objeto particular - e por isso mesmo nomeável. Na falta de uma funcionalidade, o que sobra é indício de inadequação, incompletude e deformidade.

É nesse campo de desvios onde podem ser localizadas tanto as 'coisas' de Perec em Les choses quanto as 'coisas' das acumulações de Arman. Enquanto Arman trabalhará inicialmente com objetos imperfeitos, tomados por sinais de usura, desfalque e obsolescência e que, de-formados, são 'coisas' que se aproximam da materialidade do objeto (a sua latência), Perec, em seu livro, se volta para os objetos perfeitos que servem a uma imagem coletiva de bem-estar e riqueza, e que, exatamente por isso, transcendem a condição material de simples objetos (o 'excesso' citado por Brown).

Pelas opções que esses dois artistas faziam em suas obras iniciais, eles já definiam o território do que ainda estaria por vir. No caso de Perec isso se evidenciou pela preferência em nomear seu livro 'As coisas' em detrimento de 'Os objetos'. Ao invés de lidar com as ações/resoluções do que é objetivo, direto e funcional, ele se voltava para o campo da transgressão, onde valores, sentidos e motivações são sempre mais difíceis de precisar.

\footnotetext{
${ }^{59}[. .$.$] things is a word that tends, especially at its most banal, to index a certain limit or liminality, to hover$ over the threshold between the nameable and unnameable, the figurable and unfigurable, the identifiable and unidentifiable [...]. BROWN. Thing Theory. In: Things, 2004, p. 5.

${ }^{60}$ Temporalized as the before and after of the object, thingness amounts to a latency (the not yet formed or the not yet formable) and to an excess (what remains physically or metaphysically irreducible to objects). Ibidem.
} 


\title{
1.2. Perec e a compulsão pelas coisas
}

\begin{abstract}
“Que é uma coisa?”. Imediatamente uma dúvida nos assalta. Dir-se-á que faz sentido utilizar e consumir as coisas disponíveis, pôr de lado as coisas que estorvam, arranjar as que são necessárias; mas com a questão "que é uma coisa?” não se pode, propriamente, começar nada. Assim é. Com ela não se pode começar nada.
\end{abstract}

Martin Heidegger ${ }^{61}$

Um narrador anônimo começa descrevendo um interior doméstico tendo por guia um olho - revelando já no incipit a importância da visualidade como intermediação com a realidade descrita. Diz o narrador: "O olho, de início, deslizaria sobre o carpete cinza de um longo corredor, alto e estreito." ${ }^{62}$ (Lc, p. 9). A descrição do espaço é minuciosa e o olho passa por todos os ambientes da habitação, assinalando dimensões, qualificando os cômodos, especificando os tipos de móveis, a quantidade, os revestimentos e até os enfeites dispostos numa prateleira, como acontece, por exemplo, na primeira sala visitada:

[...] um outro sofá, perpendicular ao primeiro, recoberto de veludo marrom claro, conduziria a um pequeno móvel alto com pés, laqueado de vermelho escuro, guarnecido com três estantes que suportariam enfeites: ágatas e ovos de pedra, caixas de rapé, bomboneiras, cinzeiros de jade, uma concha de madrepérola, um relógio de bolso em prata, um copo cinzelado, uma pirâmide de cristal, uma miniatura dentro de uma moldura oval. ${ }^{63}$ (Lc, p. 10).

Dessa sequência de objetos não é possível saber nada além de uma simples localização - estão lá, foram reconhecidos e ordenados pelo narrador na sua descrição. Mas, se ao longo de todo o primeiro capítulo, objetos e espaços são descritos em minúcias e com precisão, as ações que poderiam certificar alguma existência concreta se mantêm no campo do incerto pelo uso do futuro do pretérito simples (Conditionnel Présent, em francês) - tempo verbal do desejo, da hipótese, da gentileza, do conselho e do arrependimento: “A primeira porta daria para um quarto [...]. Uma grande cama inglesa ocuparia todo o seu fundo. [...] duas estantes estreitas e altas conteriam alguns livros [...]." ${ }^{64}$ (Lc, pp. 11-12). Ao longo de todo o primeiro capítulo o olho continuará seu passeio por essa morada-utópica onde: “a vida [...] seria fácil,

\footnotetext{
${ }^{61}$ HEIDEGGER. Os diferentes modos de questionar acerca da coisa. In: Que é uma coisa?, 2002, p. 14.

${ }^{62}$ L'œil, d'abord, glisserait sur la moquette grise d'un long corridor, haut et étroit.

${ }^{63}[. .$.$] un autre divan, perpendiculaire au premier, recouvert de velours brun clair, conduirait à un petit meuble$ haut sur pieds, laqué de rouge sombre, garni de trois étagères qui supporteraient des bibelots: des agates et des aufs de pierre, des boîtes à priser, des bonbonnières, des cendriers de jade, une coquille de nacre, une montre de gousset en argent, un verre taillé, une pyramide de cristal, une miniature dans un cadre ovale.

${ }^{64}$ La première porte ouvrirait sur une chambre [...]. Un grand lit anglais en occuperait tout le fond. [...] deux étagères étroites et hautes contiendraient quelques livres [...].
} 
seria simples. Todas as obrigações, todos os problemas que implicam a vida material encontrariam uma solução natural." ${ }^{65}$ (Lc, p. 14). Só ao final do capítulo é que o leitor é apresentado aos moradores desse lugar incerto, designados pela forma plural, impessoal e neutra de um 'eles'.

Nesse momento, o narrador destaca a harmonia que existe entre os moradores, o espaço e os objetos:

O conforto ambiente lhes pareceria um fato conquistado, um dado inicial, um estado da natureza deles. ${ }^{66}$ (Lc, p. 15).

Às vezes parecia-lhes que uma vida toda poderia escoar entre essas paredes cobertas de livros, entre esses objetos domesticados tão perfeitamente que eles acabariam por acreditar que eles haviam sido feitos exclusivamente para o uso deles, entre essas coisas belas e simples, doces, luminosas. ${ }^{67}$ (Lc, p. 16).

No capítulo seguinte, a narrativa deixa para trás o ambiente doméstico, harmonioso e feliz, descrito inicialmente, passando para um espaço no qual os moradores, um casal de jovens franceses - Jérôme e Sylvie -, mesmo acreditando que teriam gostado de ser ricos e que teriam sabido sê-lo, não o são e que, exatamente por isso, se sentem privados da condição de serem felizes. O narrador afirma num tom quase acusatório: "Eles não tinham nada que não merecessem ter. [...] Era a realidade deles, e eles não tinham outra." ${ }^{68}$ (Lc, pp. 17-18). O narrador comprova isso pela descrição que faz do lugar onde moram e no julgamento premonitório que apresenta ao final:

Eles viviam num apartamento minúsculo e charmoso, de teto baixo, que dava para um jardim. [...] $\mathrm{O}$ edifício era velho, não a ponto de desmoronar ainda, mas vetusto, rachado. Os corredores e as escadas eram estreitos e sujos, escorrendo umidade, impregnados de vapores gordurosos. [...].

[...] no interior, tudo começava a desabar sob o empilhamento de objetos, de móveis, de livros, de pratos, de papelada, de garrafas vazias. Começava uma guerra de usura da qual eles nunca sairiam vencedores. ${ }^{69}$ (Lc, pp. 19-20).

${ }^{65}$ La vie [...] serait facile, serait simple. Toutes les obligations, tous les problèmes qu'implique la vie matérielle trouveraient une solution naturelle.

${ }^{66}$ Le confort ambiant leur semblerait un fait acquis, une donnée initiale, un état de leur nature.

${ }^{67}$ Il leur semblerait parfois qu'une vie entière pourrait harmonieusement s'écouler entre ces murs couverts de livres, entre ces objets si parfaitement domestiqués qu'ils auraient fini par les croire de tout temps créés à leur unique usage, entre ces choses belles et simples, douces, lumineuses.

${ }^{68}$ Ils n'avaient que ce qu'ils méritaient d'avoir. [...] C'était leur réalité, et ils n'en avaient pas d'autre.

${ }^{69}$ Ils vivaient dans un appartement minuscule et charmant, au plafond bas, qui donnait sur un jardin. [...] La maison était vieille, non point croulante encore, mais vétuste, lézardée. Les couloirs et les escaliers étaient étroits et sales, suintants d'humidité, imprégnés de fumées graisseuses. [...]. / [...] à l'intérieur, tout commençait à crouler sous l'amoncellement des objets, des meubles, des livres, des assiettes, des 
Pelo que se verá mais à frente, nem o lugar diminuto, nem a carestia são males que afligem apenas esse casal, outros compartilham essas limitações com eles: "Assim eles viviam, eles e seus amigos, nos seus pequenos apartamentos atravancados e simpáticos [...].” ${ }^{70}$ (Lc, p. 63).

Após o início irreal, o narrador passa a empregar o pretérito imperfeito (o imparfait em francês) - tempo verbal que acompanha as atividades rotineiras, as ações repetitivas e previsíveis, parecendo entrar no tempo normal de uma narrativa - e passa a descrever a maneira como se desenrolava a vida desse casal, que morava no centro de Paris e tinha muitos amigos. Jérôme e Sylvie haviam largado a faculdade, indo trabalhar como pesquisadores de mercado, perguntando às pessoas na rua o que elas pensavam, se lembravam, gostavam, desejavam a respeito de todo tipo de produto, serviço, atividade etc. - função que, segundo o narrador, fora adotada por eles "não por escolha, mas por necessidade".

Através da fala fria e distante do narrador, a trajetória de Jérôme e Sylvie se dá sem diálogos. Além de não terem voz, esses personagens também não têm corpo, rosto, ideias ou um passado que revele uma expressão, uma reação, um impulso, uma lembrança ou um sentimento que os individualize.

Se seus amigos, colegas e parentes não tinham nome, os bares que frequentavam, as ruas por onde passavam, os filmes aos quais assistiam, os jornais que liam e muito do que vestiam tinham um nome, uma designação, uma marca. Suas vidas são reveladas aos poucos por informações que o narrador agrupa em categorias como, por exemplo:

- as expressões que usavam e os autores que citavam durante suas entrevistas:

[...] eles assimilaram o vocabulário e os símbolos, os truques que pegavam bem: [...] certa maneira de falar, de intercalar em suas conversas com os patrões, em um tom apenas interrogador, locuções do tipo: “... não é...”, “... eu penso que talvez...”, “... de certa maneira...”, “... essa é uma pergunta que me faço...”, uma maneira de citar, nos momentos oportunos, Wright Mills, William Whyte, ou, ainda melhor, Lazarsfeld, Cantril ou Herbert Hyman, dos quais eles não tinham lido três páginas. ${ }^{71}$ (Lc, p. 32).

paperasses, des bouteilles vides. Une guerre d'usure commençait dont ils ne sortiraient jamais vainqueurs.

${ }^{70}$ Ainsi vivaient-ils, eux et leurs amis, dans leurs petits appartements encombrés et sympathiques [...].

${ }^{71}[\ldots]$ ils assimilèrent le vocabulaire et les signes, les trucs qui faisaient bien: [...] une certaine manière de parler, d'intercaler dans leurs conversations avec les patrons, sur un ton à peine interrogateur, des locutions du genre de: “... n'est-ce pas...”, “... je pense peut-être...”, “... dans une certaine mesure...”, “... c'est une question que je pose...”, une certaine manière de citer, aux moments opportuns, Wright Mills, William Whyte, ou, mieux encore, Lazarsfeld, Cantril ou Herbert Hyman, dont ils n'avaient pas lu trois pages. 
- o que vestiam e calçavam:

Eles mergulharam com arrebatamento na moda inglesa. Descobriram as roupas de lã, os vestidos de seda, as camisas de Doucet, as echarpes, os lenços de seda, o tweed, a lã de carneiro, o cashmere, a vicunha, o couro e o Jersey, o linho, a magistral hierarquia de sapatos, enfim, que vão dos Churchs aos Weston, dos Weston aos Bunting, e dos Bunting aos Lobb. ${ }^{72}$ (Lc, pp. 35-36).

- os cinemas que frequentavam e os filmes aos quais assistiam:

[...] eles se encontravam sem combinar na Cinemateca, no Passy, no Napoléon, ou nos cinemas pequenos de bairro - o Kursaal nos Gobelins, o Texas em Montparnasse, o Bikini, o Mexico na place Clichy, o Alcazar em Belleville, e outros ainda, na região da Bastille ou do Décimo Quinto [...]. Eles guardavam uma lembrança maravilhada dessas noitadas abençoadas quando eles tinham descoberto, ou redescoberto, quase ao acaso, o Corsário vermelho, ou $O$ Mundo lhe pertence, ou Os Piratas da Noite, ou Minha Irmã Eileen, ou Os Cinco mil dedos do Doutor T. ${ }^{73}$ (Lc, p. 61).

- os lugares que frequentavam na cidade de Paris:

Do Palais-Royal a Saint-Germain, do Champ-de-Mars à Étoile, do Luxembourg a Montparnasse, da ilha de Saint Louis ao Marais, das Ternes à Opéra, da Madeleine ao parque Monceau, Paris inteira era uma eterna tentação. ${ }^{74}$ (Lc, p. 18)

Eles frequentavam o Harry's New York Bar, rua Daunou, os cafés do Palais-Royal, le Balzar, Lipp, e alguns outros. ${ }^{75}$ (Lc, p. 54)

- ou ainda as cidades que visitaram quando foram morar na Tunísia:

Eles viram Gabès, Tozeur, Nefta, Gafsa e Metlaoui, as ruínas de Sbeitla, de Kasserine, de Thélepte: atravessaram cidades mortas cujos nomes noutros tempos

${ }^{72}$ Ils se plongèrent avec ravissement dans la mode anglaise. Ils découvrirent les lainages, les chemisiers de soie, les chemises de Doucet, les cravates en voile, les carrés de soie, le tweed, le lambs-wool, le cashmere, le vicuna, le cuir et le jersey, le lin, la magistrale hiérarchie des chaussures, enfin, qui mène des Churchs aux Weston, des Weston aux Bunting, et des Bunting aux Lobb.

${ }^{73}$ [...] ils se rencontraient sans s’être donné rendez-vous à la Cinémathèque, au Passy, au Napoléon, ou dans ces petits cinémas de quartier - le Kursaal aux Gobelins, le Texas à Montparnasse, le Bikini, le Mexico place Clichy, l'Alcazar à Belleville, d'autres encore, vers la Bastille ou le Quinzième [...]. Ils gardaient un souvenir émerveillé de ces soirées bénies où ils avaient découvert, ou redécouvert, presque par hasard, le Corsaire rouge, ou le Monde lui appartient, ou les Forbans de la Nuit, ou My Sister Eileen, ou les Cinq mille doigts du Docteur T.

${ }^{74}$ Du Palais-Royal à Saint-Germain, du Champ-de-Mars à l'Etoile, du Luxembourg à Montparnasse, de l'île Saint Louis au Marais, des Ternes à l'Opéra, de la Madeleine au parc Monceau, Paris entier était une perpétuelle tentation.

${ }^{75}$ Ils fréquentaient le Harry's New York Bar, rue Daunou, les cafés du Palais-Royal, le Balzar, Lipp, et quelques autres. 
lhes tinham parecido encantadores: Maharès, Moularès, Matmata, Médénine; eles prosseguiram até a fronteira líbia. ${ }^{76}(\mathrm{Lc}, \mathrm{p} .141)$

As listas parecem estar apenas introduzindo uma sequência de exemplos que sempre poderia ser maior: as roupas que vestem fazem parte da moda inglesa, os lugares que frequentam são apenas parte do que é Paris inteira e, quanto aos bares que frequentavam, ainda haveria alguns outros...

Filhos de "pequenos burgueses sem envergadura e depois estudantes amorfos e indiferenciados" 77 (Lc, p. 40), o casal de personagens não tinha raízes, família, sobrenome, cidade natal - a história que o narrador nos conta toma como ponto de partida aquilo que eles têm: a idade, o emprego, o apartamento, móveis, livros, discos e sonhos. Negando um passado ou não querendo evocá-lo, e desnaturalizando o real retratado, o narrador conta a história de Jérôme e Sylvie de maneira incerta - que soa irônica, como que duvidando de alguns dados: "Talvez eles estivessem muito marcados pelo passado [...]. Talvez eles fossem vorazes demais logo de cara [...]. A tradição - no sentido mais desprezível do termo, talvez - lhes faltasse [...]" ${ }^{78}$ (Lc, pp. 24-25); "E durante quatro anos, talvez mais [...]." ${ }^{79}$ (Lc, p. 33); "Eles eram nove ou dez." ${ }^{80}$ (Lc, p. 57). Ele também emprega tempos verbais estranhos ao enfrentamento com o real como, por exemplo, o futuro do pretérito no primeiro capítulo e o futuro do presente no último, e emprega um vocabulário que faz alusão a imagens, sonhos, devaneios, utopias, fantasias, despertares, miragens, vertigens, estados de embriaguez e deslumbramento. Muitas vezes, ele também emprega termos que amplificam, generalizam e uniformizam opiniões, valores e julgamentos, desconsiderando assim individualidades e empregando alguma forma de coletivo como, por exemplo, ao se referir ao casal: "Eles teriam gostado de ser ricos." 81 (Lc, p. 17); aos amigos do casal: "Eles eram um bando, uma equipe legal." 82 (Lc, p. 42); ou ainda, a um grupo maior do que os dois anteriores: "Talvez

\footnotetext{
${ }^{76}$ Ils virent Gabès, Tozeur, Nefta, Gafsa et Metlaoui, les ruines de Sbeitla, de Kasserine, de Thélepte: ils traversèrent des villes mortes dont les noms jadis leur avaient semblé enchanteurs: Maharès, Moularès, Matmata, Médénine; ils poussèrent jusqu'à la frontière libyenne.

${ }^{77}$ [...] fis de petit-bourgeois sans envergure, puis étudiants amorphes et indifférenciés [...].

${ }^{78}$ Peut-être étaient-ils trop marqués par leur passé [...]. Peut-être étaient-ils d'emblée trop voraces [...]. La tradition - au sens le plus méprisable du terme, peut-être - leur manquait [...].

${ }^{79}$ Et pendant quatre ans, peut-être plus [...].

${ }^{80}$ Ils étaient neuf ou dix.

${ }^{81}$ Ils auraient aimé être riches.

${ }^{82}$ Ils étaient toute une bande, une fine équipe.
} 
estivessem muito marcados pelo passado (e não só eles, aliás, mas seus amigos, seus colegas, as pessoas da idade deles, o mundo no qual eles estavam metidos)." ${ }^{83}$ (Lc, p. 24).

Todos aqueles que são citados em Les choses parecem ser partes de um determinado grupo social, de uma determinada faixa etária, posição econômica, nível educacional, formação profissional, seguidores de certo padrão de comportamento, que poderiam ser o resultado de alguma sondagem ou análise sociológica, algo parecido ao que faziam Jérôme e Sylvie com seus questionários: a composição de listas com uma infinidade de gostos, opiniões, posições e coisas, muitas coisas...

A obra perequiana é tomada por listas e elas ganham formas distintas a cada nova iniciativa desse autor. Se na relação com o mundo os personagens de Les choses agem motivados por um prazer acumulativo em que a lista surge por aquilo que eles vão acrescentando às suas vidas na forma de signos materiais que definem um tipo de pertencimento, Claude Burgelin ${ }^{84}$, tratando das inúmeras listas presentes em Espèces d'espaces [Espécies de Espaços] (1974), levanta um ponto importante para justificar o interesse de Perec por elas: "Fazer listas é delicioso, e toda classificação dá a sonhar-pensar. Tanto por aquilo que a lista ordena e constrói quanto por aquilo que lhe escapa. Perec sabe que a classificação é inimiga da liberdade e que a incompletude é produtiva." ${ }^{85}$ Esse é um aspecto revelador do trabalho de Perec com as coisas: a partir de um desejo totalizante, o agrupamento de um tipo de signo material que, pela escrita, tanto afirma uma presença quanto indica uma falta e/ou um espaço livre e/ou um exercício a ser feito.

Depois dessa introdução a Les choses, é necessário passar ao que fundamentava inicialmente a escrita de Perec enquanto porta de acesso ao real e que ele designava como 'realismo'.

\footnotetext{
${ }^{83}$ Peut-être étaient-ils trop marqués par leur passé (et pas seulement eux, d'ailleurs, mais leurs amis, leurs collègues, les gens de leur âge, le monde dans lequel ils trempaient).

${ }^{84}$ BURGELIN. Georges Perec, 2002, p. 132.

${ }^{85}$ Mettre en liste est délicieux, et tout classement donne à rêver-penser. Autant par ce que la liste ordonne et construit que par ce qui lui échappe. Perec sait que le classement est ennemi de la liberté et que l'inachèvement est productif.
} 


\subsubsection{De olho nas coisas}

Olhe bem tudo, olhe. ${ }^{86}$

Jules Verne

Na mesma época em que escrevia os rascunhos de Le Portulan - três anos antes de publicar Les choses -, Perec publicava o artigo: Pour une littérature réaliste [Por uma literatura realista ${ }^{87}$ na revista Partisans ${ }^{88}$, no qual ele definia o realismo como sendo a descrição do real, ou melhor: uma forma de ordenação do mundo, uma maneira de controlar, compreender e explicar o real, e uma maneira de combater e questionar os mitos produzidos pela sociedade que aderiam a todas as coisas.

Entendendo a literatura como uma atividade individual - o relato de uma experiência pessoal em que a escrita serve àquele que escreve 'para se conhecer ou para se compreender' - Perec entendia esse esforço como válido quando servia de ponto de partida para a compreensão de uma realidade complexa, afirmando: "A primeira exigência do realismo, a primeira separação que permite opô-lo ao resto da literatura, é assim a vontade de totalidade." ${ }^{89} \mathrm{O}$ que ele dizia com isso é que, só partindo do particular - da percepção individual do real - é que seria possível chegar ao geral e aí compor uma visão de mundo. Essa e outras ideias sobre o realismo, Perec formulava a partir das suas leituras da obra de György Lukács, que escrevia: “A concepção do mundo do escritor é na verdade o resumo, a soma, das experiências de sua vida, levadas a certo nível de generalização." 90

${ }^{86}$ Regarde de tous tes yeux, regarde. (VERNE. Michel Strogoff, 2007, p. 304). Epígrafe de PEREC. La Vie mode d'emploi, 1994b, p. 13.

${ }^{87}$ PEREC. Pour une littérature réaliste. (1962) In: L. G., 1992, pp. 47-66.

${ }^{88}$ Entre os anos 1959 e 1963, Perec se reúne com um grupo de amigos para organizar a criação de uma revista batizada La Ligne Génerale (L.G.). Entre as várias ambições do grupo estava, segundo Claude Burgelin um dos seus participantes - a (re)fundação da estética marxista. Para Perec essa iniciativa significou a oportunidade de explorar, por exemplo: o exercício crítico ao discutir o Nouveau Roman (cf. Le Nouveau Roman et le refus du réel [O Novo Romance e a recusa do real]); o exercício teórico ao explorar o conceito de realismo (cf. Pour une littérature réaliste [Por uma literatura realista]); e o exercício entusiasmado da leitura através do livro de Antelme que trata da experiência desse autor num campo de concentração (cf. Robert Antelme ou la vérité de la littérature [Robert Antelme ou a verdade da literatura]). A ideia da revista acabou não se concretizando, mas vários dos artigos foram publicados na revista Partisans. Posteriormente, esses artigos foram reagrupados e publicados em $\boldsymbol{L} . \boldsymbol{G}$. citado na nota anterior.

${ }^{89}$ La première exigence du réalisme, le premier clivage qui permette de l'opposer au reste de la littérature, est ainsi la volonté de totalité. PEREC. Pour une littérature réaliste. Op. cit., p. 54.

${ }^{90}$ La conception du monde de l'écrivain n'est certes que le résumé, la somme, des expériences de sa vie, portés à un certain niveau de généralisation. LUKÁCS. Raconter ou Décrire. (1936). In: réalisme, 1975, p. 162. Problèmes $d u$ 
A expectativa que Perec tinha do que ele chamava de 'literatura realista' era que ela permitisse a compreensão do tempo presente, a indicação das suas contradições e a ultrapassagem de limites. Ele então reconhecia como a maior dificuldade em alcançar esse objetivo, mantendo o que era complexidade e riqueza no real, a necessidade de responder às seguintes perguntas: como ver? Como manter um distanciamento que recusasse mitos, fantasias e o inexplicável? Como evitar respostas fáceis e disfarces impostos pelas ideologias dominantes? Como incitar o posicionamento crítico do leitor? Para revelar esse mundo novo, Perec escrevia: "É necessário buscá-lo sob os gestos, sob as palavras, sob os fatos, ele existe e está longe." 91

Se a leitura de Lukács havia exposto a Perec alguns dos fundamentos teóricos que apontavam a necessidade e o interesse em continuar explorando o realismo, foram as ideias de Brecht ${ }^{92}$ que instigariam Perec a atualizar e a adequar essa maneira de relacionar realidade concreta e literatura, como ele revela nessa conferência de 1967 (dois anos após a publicação de Les choses):

\begin{abstract}
Meu primeiro modelo foi Brecht. Como por acaso, fui procurar no teatro o que eu não encontrava no romance, e Brecht me ensinou uma coisa muito importante que é a noção de distanciamento, isso que é representado no teatro de Brecht, que não é um acontecimento ou um sentimento ao qual o espectador pode se agarrar, muito pelo contrário, é um sentimento ou um acontecimento que o espectador é obrigado a compreender. É um teatro que demanda enfaticamente a inteligência através da sensibilidade, e, de maneira alguma, um teatro que demanda a adesão pura e simples [...] como o teatro burguês normal. ${ }^{93}$
\end{abstract}

A noção de distanciamento é fundamental para o entendimento de algumas das estratégias adotadas por Perec: se em Les choses ela se dá pela presença de um narrador distante e irônico, nas obras relacionadas ao exercício do cotidiano ela se dará através de

${ }^{91}$ Il nous faut le chercher sous les gestes, sous les mots, sous les faits, il existe, il est lointain. PEREC. Pour une littérature réaliste. (1962) In: L. G., 1992, p. 66.

${ }^{92}$ Segundo Dominique Bertelli e Mireille Ribière, Perec tomou contato com as ideias que fundamentavam a 'noção de distanciamento', tal como foi desenvolvido e utilizado por Bertolt Brecht, por meio do seu antigo professor Jean Duvignaud em 1954, colaborador da revista Théâtre populaire, e pelos vários artigos escritos por Roland Barthes a partir de 1955 sobre a obra do poeta/dramaturgo/encenador. Cf. PRUNIER. Entretien Georges Perec / Patricia Prunier. (1967). In: PEREC. Entretiens et conférences, 2003a, p. 73.

${ }^{93}$ Mon premier modèle a été Brecht. Comme par hasard, je suis allé chercher au théâtre ce que je ne trouvais pas dans le roman, et Brecht m'a appris une chose très importante qui est la notion de distanciation, c'està-dire ce fait que ce qui est représenté sur le théâtre de Brecht, ce n'est pas un événement ou un sentiment auquel le spectateur peut s'accrocher, c'est au contraire un sentiment ou un événement que le spectateur est obligé de comprendre. C'est un théâtre qui fait entièrement appel à l'intelligence à travers la sensibilité, et pas du tout un théâtre qui fait appel à l'adhésion pure et simple [...] comme le théâtre bourgeois normal. PEREC. Pouvoirs et limites du romancier français contemporain. (1967). In: conférences, 2003a, p. 79.

Entretiens et 
regras e rituais de aproximação do real, até que em La Vie mode d'emploi, Perec empregará um sistema complexo de regras de escrita na composição da narrativa. Para que se compreenda o desdobramento dado por Perec ao distanciamento brechtiano, preciso começar indicando o significado primeiro desse procedimento.

Segundo Anatol Rosenfeld em O teatro épico de Brecht ${ }^{94}$, o dramaturgo fazia uso do 'efeito de distanciamento' [Verfremdungseffekt] para que, primeiro, os atores fossem capazes de 'mostrar' seus personagens sem ter que se transformar neles e, segundo, para que os sentimentos dos personagens não fossem transferidos ao público. Sobre isso Brecht ${ }^{95}$ escreveu:

Em momento algum deve o ator transformar-se completamente na sua personagem. [...] O ator deve mostrar apenas a sua personagem, ou melhor, não deve vivê-la [...] Somente os sentimentos pessoais do ator é que não devem ser, em princípio, os mesmos que os da personagem respectiva, para que os do público não se tornem também, em princípio, os da personagem. O público deve gozar, neste campo, de completa liberdade.

$[\ldots]$

Só se pode distanciar a personagem apresentada e mostrá-la como "precisamente esta personagem" e como "precisamente esta personagem, neste preciso momento" quando não se produz qualquer ilusão: nem a ilusão de o ator ser a personagem, nem a de a representação ser o acontecimento.

O efeito de distanciamento pensado por Brecht visava estimular no espectador um raciocínio crítico perante o que via, sendo, portanto, um instrumento didático. Ao chamar a atenção do espectador para algo que, até então, ele entendia como sendo natural e corriqueiro, ocorreria um encontro inesperado e, dessa surpresa, é que resultariam questionamentos e a possibilidade de transformação.

Blanchot foi mais um autor que se interessou pelo teatro de Brecht e suas ideias e, em O efeito de estranhamento ${ }^{96}$, ele escreve:

Brecht fará, pois, de tudo para pôr um intervalo entre os diferentes elementos de que o teatro é feito: intervalo entre o ator e a "fábula", entre o jogo e o acontecimento, entre o ator e o personagem, e sobretudo o intervalo maior entre o ator e o público, entre as duas metades do teatro. Isso recebeu um nome que se tornou quase demasiadamente célebre e que Brecht, privado de todo pedantismo, embora um tanto pedagogo, dotou de um ar de gíria, o V-Effekt, Verfremdunseffkt (sic), o efeito de estranhamento e de distanciamento, ou ainda de expatriamento.

\footnotetext{
${ }^{94}$ ROSENFELD. O teatro épico de Brecht. In: O teatro épico, 1965, pp. 143-176.

${ }^{95}$ BRECHT. Estudos sobre teatro, 2005, pp. 148-149.

${ }^{96}$ BLANCHOT. $O$ efeito de estranhamento. In: A conversa infinita, 2010b, p. 117.
} 
[a palavra estranhamento] põe em evidência a espécie de ruptura que, no novo teatro, deveria tornar mais difícil o interesse de simpatia pelo qual todo espectador se funde naquilo que vê e pelo qual é realmente tocado. A imagem em que se realiza o efeito de estranhamento é, diz Brecht, aquela que, ao permitir-nos reconhecer o objeto, o fará parecer estranho e estrangeiro.

Para alcançar os objetivos propostos pelo efeito de distanciamento, é necessário que se enfatize sempre a relatividade histórica do que é mostrado: "O que há muito tempo não muda, parece imutável”, explica Rosenfeld ${ }^{97}$, e por isso é necessário que se demonstre o que há ali de efêmero. Rosenfeld ${ }^{98}$ comenta:

\begin{abstract}
Desta forma o público reconhecerá que as próprias condições sociais são apenas relativas e, como tais, fugazes e não "enviadas por Deus". Isso é o início da crítica. Para empreender é preciso compreender. Vendo as coisas sempre tal como elas são, elas se tornam corriqueiras, habituais e, por isso, incompreensíveis. Estando identificados com elas pela rotina, não as vemos com o olhar épico da distância, vivemos mergulhados nesta situação petrificada e ficamos petrificados com ela.
\end{abstract}

É relevante notar aqui que esse sistema se auto-anula já que, após a percepção do intervalo dado pela surpresa que separa o corriqueiro do não-corriqueiro, surge um conhecimento que volta a compor outra normalidade: "Tornar estranho é, portanto, ao mesmo tempo tornar conhecido", escreve Rosenfeld ${ }^{99}$, e completa: "A função do distanciamento é a de se anular a si mesma" 100 .

Como recursos de distanciamento que valem a pena ser citados para o entendimento da maneira particular como Perec colocou em prática sua concepção de realismo, destaco:

- o uso da ironia e de outras formas de humor como, por exemplo, a sátira e a paródia.

Se o cômico, como salienta Rosenfeld, gera um afastamento quase que natural entre o espectador e o que transcorre no palco - já que o riso só é possível porque o outro é que é a vítima da situação -, o uso da ironia é sempre o espaço por excelência do estranhamento e da dúvida. Sobre a presença da ironia em Les choses, Perec afirma: "A ironia era uma maneira de olhar de viés, o que fazia aparecer as coisas". ${ }^{101}$

\footnotetext{
${ }^{97}$ ROSENFELD. O teatro épico de Brecht. In: O teatro épico, 1965, p. 152.

${ }^{98}$ Ibidem, pp. 152-153.

${ }^{99}$ Ibidem, p. 153.

${ }^{100}$ Esse resultado ambíguo do distanciamento ficará mais claro no próximo capítulo, quando for apresentado o livro de Perec: Je me souviens.

${ }^{101}$ L'ironie, c'était une manière de regarder un petit peu en biais, qui faisait apparaître les choses. PEREC. En dialogue avec l'époque. (1979). In:____. Entretiens et Conférences, 2003b, pp. 61-62. Essa maneira enviesada de olhar as coisas seria uma marca registrada de toda a produção perequiana e pode ser encontrada
} 
- a ênfase dada ao detalhe ${ }^{102}$ e à visualidade, como destaca Roland Barthes (autor que se empolgou com as inovações do teatro de Brecht e cuja obra abordou em vários artigos):

[...] no teatro, os significados mais claros são sustentados por lugares estreitos: é o detalhe que tem a maior velocidade de significação. [...] Nada pode servir melhor às intenções da estética brechtiana [do que o detalhe significante], visto que, segundo Brecht, "o próprio da elaboração artística é de conferir importância a uma coisa". O teatro brechtiano é cheio de "detalhes" [...]; o detalhe brechtiano é como um quadro dentro do quadro; ele solicita uma inteligência imediata. ${ }^{103}$

[...] Há em Brecht uma moral do detalhe; ele é uma arma contra a metafísica, uma subversão contra o mito do infinito e do inefável, quer dizer, do insignificante. ${ }^{104}$

[...] Há em Brecht uma carga extraordinária de visualidade, uma confiança perdida no olho $[\ldots] .^{105}$

Tomo a relevância dada por Barthes à visualidade no teatro de Brecht para voltar à literatura e à obra de Perec, e abordar a maneira como o interesse pelas coisas e pela visualidade, no momento da publicação de Les choses, acabou por suscitar na crítica especializada uma relação imediata da sua obra com o Nouveau Roman (como se já não fosse suficiente o destaque dado por Perec às coisas em seu livro).

Para Barthes ${ }^{106}$, o objeto moderno, pelo modo como é abordado pelo Nouveau Roman, deixava de responder a múltiplos sentidos (táteis, odorantes, mnemônicos etc.) para ser

tanto na sua escrita como nas estratégias que ele definiria para se aproximar e tratar do real, em especial, do infraordinário. Cf. MAGNÉ. Ironies Péréquiennes. In: Colloque Hégémonie de l'ironie ?, (2007), 2008.

102 Também para Lukács o detalhe tem uma importância primordial na obra realista: "É sobretudo no detalhe que se conserva [...] essa onipresença do realismo." (C'est surtout dans le détail que se conserve [...] cette omniprésence du réalisme.) LUKÁCS. Franz Kafka ou Thomas Mann? In: La Signification présente du Réalisme Critique, 1960, p. 89. Mas para ele, não se trata de um detalhe qualquer, e sim de um detalhe marcante, aquele que passou por um critério consciente do autor - uma "certa atitude em face da realidade efetiva" - para ser incluído na obra. Ele aponta Kafka como exemplo de autor que sabe operar essa seleção de detalhes significantes: "[...] um dos raros que operam uma seleção de detalhes, que retém apenas aqueles que valorizam o essencial [...]. Do ponto de vista puramente formal, sua maneira de tratar os detalhes é análoga, por consequência, nesses princípios, àquela dos realistas." ([...] l'un des rares qui opèrent une sélection des détails, qui ne retiennent que ceux qui mettent en valeur l'essentiel [...]. Du point de vue purement formel, sa manière de traiter les détails est analogue, par conséquent, dans ses principes, à celle des réalistes.) Ibidem, p. 97.

103 [...] au théâtre, les significations les plus claires sont soutenues par des lieux étroits: c'est le détail qui a la plus grande vitesse de signification. [...] Rien ne peut mieux servir les intentions de l'esthétique brechtienne, puisque, selon Brecht, "le propre de l'élaboration artistique est de conférer de l'importance à une chose". Le théâtre brechtien est plein de "détails" [...]; le détail brechtien est comme un tableau dans le tableau; il sollicite une intelligence immédiate. BARTHES. Commentaire: Préface à Brecht, "Mère courage et ses enfants". (1960). In: Euvres Complètes, 2002a, p. 1070.

104 [...] Il y a chez Brecht une morale du détail; il est une arme contre la métaphysique, une subversion contre les mythe de l'infini et de l'ineffable, c'est-à-dire de l'insignifiant. Ibidem, p. 1075.

${ }^{105}$ Il y a chez Brecht une charge extraordinaire de la visualité, une confiance éperdue dans l'œil [...]. Ibidem, 1076. 
apreendido por um único sentido: a visão. Mas esse tipo de tratamento não se limitava aos objetos e, tanto os personagens como as situações descritas, também se mostravam frequentemente frias, superficiais e esquemáticas (não por acaso, a prevalência do 'exercício do olho' sobre o mundo levava a crítica a identificar o Nouveau Roman com uma 'Escola do Olhar'). A intenção do olhar ali era tomar do mundo uma primeira impressão e comunicá-la da maneira mais neutra e objetiva possível, sem outros envolvimentos e comprometimentos sem outros sentidos. Além disso, o exercício do olho explicitava uma movimentação que se dava pela superfície das coisas, designando simples presenças, simples obstáculos que só faziam aumentar, e muitas vezes atrapalhar, o sentido das distâncias percorridas, já que, como explica Barthes ${ }^{107}$ a partir da obra de Alain Robbe-Grillet: o objeto tratado pelo Nouveau Roman não tem hereditariedade.

Conhecendo o trabalho dos autores do Nouveau Roman, é fácil entender a impressão causada pelo primeiro livro de Perec: o interesse pelos objetos, a relevância dada à visualidade, a artificialidade do discurso, o papel ambíguo do narrador etc., procedimentos que naquele momento, poderiam muito bem ligar o jovem escritor a esse movimento. Perec precisou se esforçar bastante para negar esse parentesco enquanto não publicava um próximo livro. A explicação mais recorrente dada por Perec quando comparado a Robbe-Grillet, dizia que seu modo de trabalhar o objeto era diferente do que Robbe-Grillet fazia. Num dos poucos artigos voltados às questões teóricas da literatura, publicado por Perec e Burgelin ${ }^{108}$ em 1962 , e com a intenção de criticar o Nouveau Roman, os autores diziam que o mundo apresentado ali era um "mundo entre parênteses" no qual a realidade que se apresentava estava desvinculada do tempo, da história e de qualquer contexto social, no qual o homem estaria no mesmo plano das coisas, levando Perec e Burgelin a afirmar que esse homem seria então "uma pura presença, um puro objeto, dos quais só é possível descrever a aparência incompreensível". 109

Já, quanto à linguagem, Perec afirmaria em outro momento que, enquanto RobbeGrillet buscava uma neutralidade nas palavras, para que elas simplesmente designassem o objeto, ele, Perec, buscava palavras tomadas de sentido:

\footnotetext{
${ }^{106}$ BARTHES. Littérature objective. (Essais Critiques). (1954). In: 303. . Euvres Complètes, 2002b. pp. 293-

${ }^{107}$ Ibidem, p. 295.

${ }^{108}$ PEREC; BURGELIN. Le Nouveau Roman et le refus du réel. (1962). In: PEREC. L. G., 1992, pp. 25-45.

${ }^{109}[. .$.$] une pure présence, un pur objet, dont on peut seulement décrire l'incompréhensible apparence. Ibidem,$ p. 38 .
} 
Eu quis, ao contrário, que minhas palavras fossem 'injetadas' de sentido, carregadas de ressonâncias. "Carpete", por exemplo: para mim, é uma palavra que veicula todo um sistema de valores e é precisamente o sistema de valores que impõe a publicidade [...]. As palavras que emprego não designam nem objetos, nem coisas, mas signos. São imagens. ${ }^{110}$

Ainda que, tanto na proposta de Robbe-Grillet como na de Perec, pareça imperar um mesmo tipo de vazio pela falta de sentido suscitada pela relação com as coisas, o que ocorre em Les choses é diferente do que ocorre na obra de Robbe-Grillet: o consumismo dos personagens de Les choses serviu, inicialmente, como uma justificativa fácil e rápida que poderia explicar tudo no livro de Perec. Para os livros de Robbe-Grillet não era possível encontrar esse tipo de atalho.

Em outra entrevista, Perec se posiciona novamente em oposição ao que fazia RobbeGrillet, dizendo que, em Les choses, ele havia trabalhado uma linguagem "que envolve as coisas, disso que há embaixo delas, de tudo que as nutre, de tudo que se injeta nelas" ${ }^{111}$ e que para isso ele havia sentido a necessidade de apagar a presença humana para se dedicar a compor um tipo de inventário de seu tempo.

Se o distanciamento deveria impor um esfriamento da linguagem, certa neutralidade, a ironia marcaria o que seriam as posições antagônicas encontradas num mesmo texto sobre determinada questão: o personagem adotaria certas posições e/ou desempenharia determinada ação com a qual o autor não estaria exatamente de acordo, e isso também estaria colocado no texto, anulando assim a possibilidade do texto expor não só a verdade do escritor como qualquer outra verdade absoluta. Estaria aí a liberdade mencionada por Perec: um espaço de escolha para o leitor que deveria pensar sobre o assunto e poderia, ou não, tomar partido, tirando disso algum aprendizado (uma 'consciência', segundo o que Perec pensava a partir de Brecht). Em Les choses esse é o papel do narrador que, ao mesmo tempo em que conta a fábula, destaca aspectos negativos dos personagens como, por exemplo: "E, no entanto, eles se enganavam; eles estavam a caminho de se perder." ${ }^{112}$ (Lc, p. 27); "Eles eram estúpidos -

\footnotetext{
${ }^{110}$ J'ai voulu au contraire que mes mots soient "injectés" de sens, chargés de résonances. "Moquette", par exemple: pour moi, c'est un mot qui véhicule tout un système de valeurs. Et c'est précisément le système de valeurs qu'impose la publicité. Si bien qu'on peut dire que mon texte, parfois, s’identifie à un texte publicitaire [...]. Les mots que j'emploie ne désignent ni des objets ni des choses, mais des signes. Ce sont des images. PEREC. Le bonheur est un processus... on ne peut pas s'arrêter d'être heureux. (1965). In: . Entretiens et Conférences, 2003a, p. 50.

${ }^{111}$ [...] qui entoure les choses, de ce qu'il y a en dessous, de tout ce qui les nourrit, de tout ce qu'on leur injecte [...]. PEREC. Le bonheur de la modernité. (1965). In: Entretiens et conférences, 2003a, p. 60.

${ }^{112}$ Et pourtant, ils se trompaient; ils étaient en train de se perdre.
} 
quantas vezes eles repetiam para si mesmos que eram estúpidos, que não tinham razão [...]." 113. "Assim eles sonhavam, os imbecis alegres [...]." ${ }^{114}$ (Lc, p. 101).

Esse exercício de ambiguidades também está muito presente na maneira incerta como a história é contada e que mobiliza o leitor em vários momentos, devendo ele aceitar, ou não, o que é dito pelo narrador. É assim que, depois de contar que os personagens haviam deixado Paris para ir morar em Sfax (Tunísia), onde Sylvie dava aulas enquanto Jérôme lia e perambulava pela cidade, o narrador inicia o epílogo dizendo: "Tudo poderia ter continuado assim. Eles poderiam ter permanecido ali por toda a vida" ${ }^{115}$ (Lc, p. 149). Se isso induz, mas não certifica, que tudo está para mudar, o que vem a seguir só aumenta o estranhamento, pois, a partir desse momento, toda a história passa a ser contada numa velocidade estonteante com os verbos no futuro do presente:

Eles farão suas bagagens. Eles arrumarão seus livros, gravuras, as fotografias dos amigos, jogarão fora uma quantidade enorme de papéis, darão seus móveis, suas estantes mal cortadas, seus tijolos de doze buracos, despacharão suas malas. Eles contarão os dias, as horas, os minutos. ${ }^{116}$ (Lc, p. 150).

Assim, voltando a Paris, eles enviarão muitos currículos e conseguirão um emprego em Bordeaux. Antes de deixar Paris, eles começarão a fazer planos de como será essa vida nova e, na viagem de trem para assumir o novo posto, será servida ao casal uma refeição que será francamente insípida - gosto que pode ser compartilhado pelo leitor que, após tantas incertezas que acompanham a trajetória dos personagens, terá muitas dúvidas sobre a motivação real dessa aventura/leitura. Pura inconclusão.

\footnotetext{
${ }^{113}$ Ils étaient stupides - combien de fois se répétèrent-ils qu'ils étaient stupides, qu'ils avaient tort [...].

${ }^{114}$ Ainsi rêvaient-ils, les imbéciles heureux [...].

${ }^{115}$ Tout aurait pu continuer ainsi. Ils auraient pu rester là toute leur vie.

${ }^{116}$ Ils feront leurs bagages. Ils rangeront les livres, les gravures, les photographies des copains, jetteront d'innombrables papiers, donneront autour d'eux leurs meubles, leurs planches mal équarries, leurs briques à douze trous, expédieront leurs malles. Ils compteront les jours, les heures, les minutes.
} 


\subsubsection{Os modelos de Les choses}

[...] na origem desse livro, havia um projeto duplo: de início um exercício sobre as Mitologias de Barthes, quer dizer, sobre o reflexo em nós da linguagem publicitária; em seguida, a descrição aproximada de um meio que, aliás, é o meu. É talvez por isso que levei três anos, não escrevendo, mas isolando entre todas aquelas [páginas] que tinha escrito as cento e vinte páginas definitivas do meu livro. Pois tudo era problemático: era necessário dar aos personagens uma vida específica, individualizada, era necessário fazê-los dialogar e sobre o quê? Com relação aos seus personagens, um autor tem pouca liberdade: ele pode estar embaixo deles, ou ainda neles, no interior deles; eu, eu escolhi estar ao lado deles. Vão me censurar, talvez, como uma facilidade: tenho que preservar essa possibilidade que me é dada de me afastar ou de me aproximar, à vontade, deles. ${ }^{117}$

Georges Perec

Durante o exercício de escrita de Les choses, Perec enfrentaria três perguntas do exercício literário: ‘o que escrever?', 'como escrever?' e 'a partir do que escrever?'.

Sobre 'o que escrever?' Perec respondeu com uma visão crítica que tinha como modelo o livro Mitologias [Mythologies] de Roland Barthes ${ }^{118}$, além dos cursos que havia feito com o crítico na École pratique des hautes études, em especial um seminário sobre o discurso publicitário. Segundo Barthes ${ }^{119}$, "o mito é um sistema de comunicação, é uma mensagem" que pode se fixar em tudo porque não é objeto, conceito ou ideia, é uma forma que transforma a história em natureza, ou seja, o mito anula tudo o que é real e que está ligado à produção, à hereditariedade, ao esforço humano, para impor a ordem do 'é assim', 'sempre foi assim'. Como explica Barthes ${ }^{120}$ :

Passando da história à natureza, o mito faz uma economia: abole a complexidade dos atos humanos, confere-lhes a simplicidade das essências, suprime toda e qualquer dialética, qualquer elevação para lá do visível imediato, organiza um

${ }^{117}$ [...] à l'origine de ce livre, il y avait un projet double: d'abord un exercice sur les Mythologies de Barthes, c'est-à-dire sur le reflet en nous du langage publicitaire; ensuite, la description aux traits à peine appuyés d'un certain milieu, qui d'ailleurs est le mien. C'est peut-être pour cela que j'ai mis trois ans, non pas à écrire, mais à isoler parmi toutes celles que j'avais écrites les cent vingt pages définitives de mon livre. Car tout faisait problème: fallait-il donner aux personnages une vie spécifique, individualisée, fallait-il les faire dialoguer et sur quoi? Par rapport à ses personnages, un auteur a peu de liberté: il peut être au-dessus d'eux, ou bien en eux, à l'intérieur d'eux; moi, j'ai choisi d'être à leurs côtés. On me le reprochera peut-être comme une facilité: mais je tiens à préserver cette possibilité qui m'est donnée de m'éloigner ou de m'approcher, à volonté, d'eux. PEREC. Le bonheur est un processus... on ne peut pas s'arrêter d'être heureux. (1965). In: Entretiens et Conférences, 2003a, p. 48.

${ }^{118}$ Mitologias é uma série de ensaios sobre a sociedade de consumo francesa, escritos entre 1954 e 1956 , que Roland Barthes publicou na forma de livro em 1957. Cf. BARTHES. Mitologias, 2001.

${ }^{119}$ BARTHES. Mitologias, 2001, p. 131.

${ }^{120}$ Ibidem, pp. 163-164. 
mundo sem contradições, porque sem profundeza, um mundo plano que se ostenta em sua evidência, cria uma clareza feliz: as coisas parecem significar sozinhas, por elas próprias.

Assim, o mito é uma mensagem que sugere algo sobre uma mensagem que designa uma coisa. Enquanto as mensagens que designam um objeto, por exemplo, explicitam sua utilidade, seu material, sua durabilidade, seu funcionamento, sua praticidade, sua disponibilidade, sua origem e seu custo - características que poderiam ser avaliadas pelo usuário ao experimentá-lo, avaliá-lo e compará-lo com outros objetos semelhantes -, a mensagem mitológica, por meio de imagens e fantasias, atrela ao objeto certas noções de gosto, de posição social, de potência, de superioridade, etc., que, sendo puras incertezas disfarçadas de simplicidade, dão a entender que pertencem ao objeto, sendo, portanto evidentes e naturais, raramente incitando algum tipo de questionamento. Como essas imagens são extremamente atraentes aos olhos, principalmente porque parecem fáceis, disponíveis e amigáveis, o homem se apaixona por elas. Esse é o grande atrativo do consumismo: o prazer das imagens. O objeto, nessas condições, livre do que nele é matéria, forma, trabalho e funcionamento, se transforma em 'coisa' a serviço de uma fantasia que não se sabe exatamente a que $(m)$ serve.

Em Les choses o que mais atrai Jérôme e Sylvie é principalmente o que eles entendem que as coisas sugerem - que é da ordem da fantasia, do mito - e não exatamente aquilo que elas são - que é da ordem da necessidade, da funcionalidade, da durabilidade, do trabalho e do custo - e é por isso que eles fazem o possível para evitar um confronto com o real, preferindo tratar com o que tem a dimensão da utopia: "Eles poderiam falar de outra coisa, de um livro recentemente lançado, de um diretor de teatro, da guerra, ou dos outros, mas lhes parecia às vezes que suas únicas conversas verdadeiras se referiam a dinheiro, a conforto, à felicidade." $^{121}$ (Lc, p. 77).

O narrador, enquanto descreve as trajetórias dos personagens pelo caminho do consumismo, parece desempenhar o papel de promotor de estranhamento - tal como propagava Brecht - por apontar a incoerência e a inconsequência das ações dos personagens:

O amor deles pelo bem-estar, pela melhoria, se traduzia mais frequentemente por um proselitismo besta [...]. Eles se entusiasmavam por uma valise [...]. Mas os gestos, um pouco sacralizados, que tinham de se entusiasmar na frente da vitrine de um alfaiate, de uma costureira ou de um sapateiro, na maioria das vezes só servia para

${ }^{121}$ Ils pouvaient certes parler d'autre chose, d'un livre récemment paru, d'un metteur en scène, de la guerre, ou des autres, mais il leur semblait parfois que leurs seules vraies conversations concernaient l'argent, le confort, le bonheur. 
torná-los um pouco ridículos. ${ }^{122}$ (Lc, pp. 23-24).

[...] Muito frequentemente, eles não amavam, nisso que chamavam de luxo, outra coisa a não ser o dinheiro que havia por trás dele. Eles sucumbiam aos símbolos da riqueza: amavam a riqueza antes de amar a vida. ${ }^{123}$ (Lc, p. 25).

As ideias de Brecht justificam as várias maneiras como Perec vai empregar o efeito de distanciamento em seu livro: o mutismo dos personagens, os tempos verbais incomuns, a voz dissonante do narrador que analisa, critica, julga e que serve para quebrar o fluxo da narrativa, impedir alguma empatia com os personagens e colocar o leitor em dúvida: quem tem razão?

Agora, sobre a pergunta 'como escrever?' o modelo mais importante - e que Perec citava sempre que precisava falar de Les choses - é tirado de L'Éducation sentimentale [A Eduação Sentimental], de Flaubert ${ }^{124}$. Perec chega mesmo a dizer que a razão mais forte pela qual ele se aproximou dessa obra era de 'querer ser Flaubert' e fazer um pastiche de seu texto $^{125}$. Ele resume o uso que faz dessa obra para escrever seu livro em duas entrevistas que se seguiram ao lançamento do livro. Na primeira Perec trata do estilo: "Eu precisava de um modelo e eu não recuso influências. Sob meu ponto de vista, o estilo de Flaubert é dos mais frios e essa frieza era necessária para mim." ${ }^{126}$ E na segunda ele trata de três maneiras práticas através das quais fez uso da obra de Flaubert:

Minha utilização de Flaubert se faz em três níveis: inicialmente pelo ritmo ternário, que se tornou em mim um tipo de tique; em seguida, eu tomei de Flaubert certas figuras exemplares, certos elementos bem organizados, um pouco como as

${ }^{122}$ Leur amour du bien-être, du mieux-être, se traduisait le plus souvent par un prosélytisme bête [...]. Ils s'enthousiasmaient pour une valise [...]. Mais les gestes, un peu sacralisés, qu'ils avaient pour s'enthousiasmer devant la vitrine d'un tailleur, d'une modiste ou d'un chausseur, ne parvenaient le plus souvent qu'à les rendre un peu ridicules.

${ }^{123}$ Trop souvent, ils n'aimaient, dans ce qu'ils appelaient le luxe, que l'argent qu'il y avait derrière. Ils succombaient aux signes de la richesse: ils aimaient la richesse avant d'aimer la vie.

${ }^{124}$ Cf. FLAUBERT. L'Éducation sentimentale, 2007.

Nas entrevistas de Perec logo após a publicação de Les choses, ele também mencionaria como seus 'modelos literários': La Conspiration [A Conspiração], de Paul Nizan, e L’Espèce humaine [A Espécie Humana], de Robert Antelme. O primeiro livro é sobre um casal de jovens que se envolve em um malogrado plano revolucionário e o segundo trata da passagem do autor por um Campo de Concentração. Essas duas referências sumiriam futuramente e Perec passaria a falar apenas sobre os três modelos que cito neste item. Essas obras continuam sendo importantes para a escrita de Les choses (mas não apenas elas) porque Perec retirou delas várias frases que incluiria em seu livro (esse foi um exercício de ‘colagem' que Perec continuaria a aprimorar ao longo da sua obra). Cf. PEREC. En dialogue avec l'époque. (1979). In:

Entretiens et Conférences, 2003b, p. 62.

${ }^{125}$ Cf. PEREC. $\underline{A}$ propos des Choses. (1981). In: Entretiens et Conférences, 2003b, p. 269.

${ }^{126}$ J'avais besoin d'un modèle et ne refuse pas les influences. À mes yeux, le style de Flaubert est le plus glacial qui soit et cette froideur m'était nécessaire. PEREC. Georges Perec, lauréat du "Renaudot". (1965). In: . Entretiens et conférences, 2003a, p. 44. 
cartas de tarô: a viagem de navio, a manifestação das ruas, o leilão... Enfim, frases recopiadas, transcritas pura e simplesmente. ${ }^{127}$

É por essa obra de Flaubert, um clássico do romance de formação, que Perec constrói a trajetória do casal de Les choses, com a diferença que, no livro de Perec, praticamente não existem conflitos nem entre os personagens, nem de ordem psíquica e/ou moral. No livro de Perec a formação dos personagens se dá pela relação que eles estabelecem com as coisas, o que permite dizer que Les choses é um 'Livro de Formação do Gosto' - porque o 'gosto', motivado pelo dinheiro, é a única variável que o próprio narrador reconhece como 'em processo de amadurecimento', como ele sugere, por exemplo, nesses momentos: “O gosto deles se formou lentamente, mais confiante, mais ponderado. Os desejos deles tiveram o tempo de amadurecer; a cobiça deles se tornou menos agressiva." ${ }^{128}$ (Lc, p. 26); "Pela primeira vez, eles ganharam algum dinheiro. [...] De ano em ano, ele os transformou." 129 (Lc, p. 35); "Eles mudavam, eles se tornavam outros. [...] Mas o dinheiro - esse tipo de comentário é inevitavelmente banal - suscitava necessidades novas." ${ }^{130}$ (Lc, p. 38).

Já, para responder 'a partir do que escrever?', Perec deu dois tipos de resposta: na primeira ele afirmou que o ponto de partida era a experiência pessoal, não para compor uma escrita autobiográfica, como eu escrevi anteriormente, nem para relatar e/ou resgatar qualquer tipo de problemática interior, psicológica, subjetiva, mas para propor uma perspectiva, um ponto de vista particular de quem se esforçava em compreender seu tempo. Já, na segunda resposta, ele trata do acervo de informações que precisou para compor, não só a vida de seus dois personagens, mas de toda uma geração que vivia a mesma coisa que eles, essas informações ele encontrou tanto no suplemento feminino do periódico L'Express: Madame Express, sua 'enciclopédia de mitologias contemporâneas', como em outras publicações semelhantes, por exemplo: Elle, Votre Maison etc. Era para esses mundos que ele olhava enquanto também lia Mitologias, de Barthes.

\footnotetext{
${ }^{127}$ Mon utilisation de Flaubert se fait à trois niveaux: d'abord le rythme ternaire, qui était devenu chez moi une sorte de tic; ensuite, j'ai emprunté à Flaubert certaines figures exemplaires, certains éléments tout organisés, un peu comme des cartes de tarot: le voyage en bateau, la manifestation de rues, la vente aux enchères... Enfin, des phrases recopiées, retranscrites purement et simplement. PEREC. Le bonheur est un processus... on ne peut pas s'arrêter d'être heureux. (1965). In: Entretiens et Conférences, 2003a, p. 48.

${ }^{128}$ Leur goût se forma lentement, plus sûr, plus pondéré. Leurs désirs eurent le temps de mûrir; leur convoitise devint moins hargneuse.

${ }^{129}$ Pour la première fois, ils gagnèrent quelque argent. [...] D'année en année, il les transforma.

${ }^{130}$ Ils changeaient, ils devenaient autres. [...] Mais l'argent - une telle remarque est forcément banale suscitait des besoins nouveaux.
} 
Se essas publicações serviam de modelo a Perec para indicar quais seriam as melhores iscas que, jogadas sobre os personagens, poderiam atraí-los para o consumo, no interior do livro de Perec é L'Express que domina. No caminho do consumo L'Express deveria servir aos personagens como um guia de viagem, ou talvez, como um manual de conduta, como reforçam as falas do narrador: “ $L$ 'Express era sem dúvida o semanário que eles mais valorizavam. [...] L'Express, e só ele, correspondia à arte de viver deles; eles encontravam nele, cada semana [...] as preocupações mais corriqueiras da vida deles de todo dia." ${ }^{131}$ (Lc, p. 45); "Eles não buscavam esconder: eram as pessoas para L'Express. Eles precisavam, sem dúvida, que a liberdade, a inteligência, a alegria e a juventude deles fossem, sempre, em todos os lugares, convenientemente significadas. Eles se deixavam tomar sob sua responsabilidade [...]." ${ }^{132}$ (Lc, pp. 46-47); “L'Express oferecia a eles todos os signos do conforto [...]. Eles sonhavam, baixinho, com sofás Chesterfield. L'Express também sonhava com isso." ${ }^{133}$ (Lc, p. 47).

\subsection{O objeto na obra}

O Nouveau Réalisme [Novo Realismo], movimento artístico surgido na França no início dos anos sessenta, introduz algumas transformações importantes no panorama artístico francês que seriam posteriormente consideradas deflagradoras do que hoje entendemos por Arte Contemporânea ${ }^{134}$. Das alterações mais importantes que interessam a esta pesquisa estão: em primeiro lugar, a incorporação do objeto ao campo da expressão artística e a mudança da postura do artista perante aquilo que ele nos apresenta como obra.

${ }^{131}$ L'Express était sans doute l'hebdomadaire dont ils faisaient le plus grand cas. [...] l'Express, et lui seul, correspondait à leur art de vivre; ils retrouvaient en lui, chaque semaine [...] les préoccupations les plus courantes de leur vie de tous les jours.

${ }^{132}$ Ils ne s'en cachaient pas: ils étaient des gens pour l'Express. Ils avaient besoin, sans doute, que leur liberté, leur intelligence, leur gaieté, leur jeunesse soient, en tout temps, en tous lieux, convenablement signifiées. Ils le laissaient les prendre en charge [...].

${ }^{133}$ L'Express leur offrait tous les signes du confort [...]. Ils rêvaient, à mi-voix, de divans Chesterfield. L'Express y rêvait avec eux.

${ }^{134}$ O Nouveau Réalisme foi um movimento artístico liderado pelo crítico Pierre Restany e contava com treze artistas, entre os quais: Yves Klein, Arman e César. Na Declaração Constitutiva do movimento está escrito: "Os novos realistas tomaram consciência de sua singularidade coletiva. Novo realismo = novas aproximações perceptivas do real." (Les nouveaux réalistes ont pris conscience de leur singularité collective. Nouveau réalisme $=$ nouvelles approches perceptives du réel.). FRANCBLIN. $\underline{\text { Chronologie }}$ 1945-1970. In: Les Nouveaux Réalistes, 1997, p. 73. 
O novo estatuto do objeto nos anos sessenta retoma alguns questionamentos no campo epistemológico da arte surgidos no início do século, principalmente com Duchamp e a ideia de ready-made ${ }^{135}$. Com o Nouveau Réalisme o objeto não se apresentava como figura única, emblemática, separada do mundo que lhe daria sentido e também não era simples deslocamento, transposição. Havia sempre ali, junto ao objeto, a presença de um estranhamento, de uma obsessão, de um procedimento, de uma crítica que se faziam visíveis pela repetição e pela veemência explícita com a qual o artista efetivava sua proposição.

$\mathrm{O}$ aspecto desse movimento artístico que interessa aqui é a maneira como esses artistas se voltam para o real em busca do que Pierre Restany chama de 'um novo senso moderno da natureza urbana'. Para efetivar uma relação direta, os artistas deixam seus ateliês, se lançam pelos espaços da cidade e põem em prática um exercício de apropriação do objeto tomado do real urbano e doméstico que resultará em colagens e assemblages ${ }^{136}$ de vários tipos. Para esses artistas, não se tratava de reaproveitar ou de transformar o objeto por meio de procedimentos que positivassem ou valorizassem algo que, na origem, era uma negatividade a ser sinalizada. A intenção agora era exacerbar uma constatação que não permitisse outra projeção, outro tempo, outro espaço ou outro significado que não fosse o confronto presente do observador com o real. $O$ que se passava entre a obra e o observador ocorria simultaneamente e no mesmo nível das relações que o observador estabelecia com o seu real próximo e particular - a fonte mais potente de assombros de uma sociedade que vivia um período chamado 'Trinta anos Gloriosos' (1945-1975) no qual se experimentavam os primeiros momentos de abundância após o grande desastre da Segunda Grande Guerra.

Os objetos que atraíam a atenção dos artistas franceses não eram os mesmos que, naquele momento, enchiam os olhos de um público seduzido por novas tecnologias, novas formas e cores que surgiam numa quantidade e diversidade crescentes. Muito pelo contrário, as escolhas, os procedimentos e as ações dos artistas do Nouveau Réalisme, antes de louvarem, criticavam, provocavam e até mesmo acusavam uma presença incômoda e invisível à maioria.

\footnotetext{
${ }^{135}$ READY-MADE: termo criado por Marcel Duchamp na segunda década do século XX para designar objetos do cotidiano produzidos industrialmente, os quais ele tomava do espaço onde eram comercializados para expôlos diretamente em espaços de arte. Essa maneira de incluir o objeto cotidiano no universo da arte pode ser entendida como um deslocamento efetuado para chamar a atenção do observador às convenções, hábitos e preconceitos que participariam da concepção do objeto e/ou fato artístico. Cf. BATCHELORD. "Essa Liberdade e essa ordem": A arte na França após a Primeira Guerra Mundial. In: FER; BATCHELORD; WOOD. Realismo, Racionalismo, Surrealismo, 1998, pp. 35-39.

${ }^{136}$ ASSEMBLAGE: colagem tridimensional feita com todo tipo de material e/ou objeto.
} 
Nesse novo tipo de configuração da obra, deixa de ser particular e único o modo como a obra se apresenta ao olhar do público porque ela é apenas um modelo que deve ser repetido inúmeras vezes até ser esgotado. Quanto ao novo objeto apresentado pelo artista e que não é o simples objeto subtraído da realidade, nem uma escultura que duplica de modo direto o objeto do cotidiano, é agora um exemplar de um gênero novo. Como escreve Maurice Eschapasse: "A obra deixa de ser o autógrafo insubstituível: simples protótipo, ela pode ser editada sob a forma de múltiplos; destruída, ela é reconstituível se os ingredientes de base estão sempre disponíveis" ${ }^{137}$. O imediatismo dos gestos, a presença do artista no contexto dos atos do cotidiano e a precariedade e instabilidade dos materiais utilizados - incapazes de configurar algo como 'percebível artisticamente' - provocavam no público embaraços e/ou indiferença.

O maior problema na proposta dos artistas do Nouveau Réalisme é que, ao trazerem o objeto para o âmbito da obra, eles acabaram enfraquecendo o caráter autossuficiente da obra. O 'ser-obra' da obra precisava então de novos indícios que caracterizassem uma permanência capaz de dotar a obra de uma autossuficiência. Isso teria que se dar, não anulando o 'serobjeto' do objeto - já que a intenção desses artistas era que o objeto fosse reconhecido como tal -, mas acrescentando outras informações que agregassem à obra uma potência - a potência instauradora de um mundo, diria Heidegger ${ }^{138}$. É assim que, para enfatizar a sua ação como um gesto expressivo, o artista passava a preparar estratégias que chamassem a atenção do público não só para aquilo que ele indicava como relevante no real, como também para si próprio enquanto agente dessa ação. No universo da materialidade da obra, passava agora a ser significativo acompanhar de perto o gesto do artista, fotografando-o, filmando-o e entrevistando-o. Quanto mais o gesto/obra do artista se aproximava do real, maior relevância teria o que preparava, executava e apresentava o resultado das suas ações.

Maurice Eschapasse ${ }^{139}$ nota que, para esses artistas, o que é singular não é tanto o resultado final - suas montanhas de objetos, máquinas, engrenagens, sucata, detritos - , mas um tipo de ação sistemática que parece simular o próprio exercício de fabricação. O particular do artista agora é a sua obsessão por um tipo específico de material, de objeto ou de procedimento (ou uma variação entre eles). Eschapasse, ao invés de designar cada uma das tentativas do artista como 'obras', prefere designá-las como 'peças' - componentes de um

\footnotetext{
${ }^{137}$ L'oeuvre cesse d'être l'autographe irremplaçable: simple prototype, elle peut être éditée sous forme de multiples; détruite, elle est reconstituables si les ingrédients de base sont toujours disponibles. ESCHAPASSE. L'avènement de l'objet. In: Douze ans d'art contemporain en France, 1972, p. 61.

${ }^{138}$ Cf. HEIDEGGER. A origem da obra de arte, 2004.

${ }^{139}$ ESCHAPASSE. Op. cit., p. 66.
} 
grupo maior que ele chama de 'série'. Essas peças alcançam algum sentido e indicam uma direção nos esforços do artista por meio da execução repetitiva do empreendimento e do encadeamento das várias unidades: é assim que Arman passa a ser reconhecido como 'o artista das acumulações', ou seja, mais que um artista de uma forma ou de um tema, ele foi o artista de um procedimento, não importando exatamente o tipo, tamanho, lugar ou origem dos objetos que utilizava. E o próprio Perec, em função da sua participação no OuLiPo e pelo uso que fazia de modelos/estruturas/regras de escrita, também se notabilizou algumas vezes, mais por alguns dos procedimentos adotados para escrever um livro do que exatamente pela obra que dali resultava ${ }^{140}$.

\subsubsection{Arman, um coletor do seu tempo} Eu sempre fui atraído pelo que é multiplicado [...]. Eu gosto de vitrines de lojas de
máquinas fotográficas ou de vitrines de lojas de ferramentas ou de brinquedos.
Quando eu tirava fotografias, eu gostava de repetir as mesmas imagens. ${ }^{141}$

Arman

Os objetos e as acumulações sempre fizeram parte da vida de Arman (Armand Pierre Fernandez, 1928-2005) - um 'coletor do seu tempo'. Ele criou sua primeira acumulação em 1959, quando colocou uma placa de poliéster sobre uma gaveta cheia de um mesmo tipo de lâmpadas, pintou as laterais da gaveta de preto e colocou a gaveta na posição vertical. O artista repetia o que parece ter sido uma mania familiar: guardar (acumular) muitas coisas em gavetas, caixas, armários etc.

\footnotetext{
${ }^{140}$ Exemplo disso é seu livro La disparition, célebre por não conter nem uma única letra 'e'. Cf. item 2.2.

${ }^{141}$ J'ai toujours été attiré par ce qui est multiplié [...]. J'adore les vitrines des magasins d'appareils photo ou les vitrines des magasins d'outillage ou de jouets. Quand je faisais de photographies, j'aimais répéter les mêmes images. ARMAN apud FRANCBLIN. Propos recueillies par l'auteur, mai 1996. In: Nouveaux Réalistes, 1997, p. 48.
} 
O exercício artístico de Arman nunca se voltou para o exercício autobiográfico, muito pelo contrário, os objetos que usava não traziam qualquer marca pessoal (mesmo que saíssem de suas próprias gavetas). Ele acabou mesmo se consagrando pelo uso obsessivo, repetitivo, mecânico e profícuo de todo tipo de objetos do cotidiano, em configurações que dizem respeito às etapas do processo de produção industrial: a automação, o exercício em série, à impessoalidade, à obsolescência e, finalmente, ao descarte final. Resulta que a acumulação, ou, a 'poética da quantidade', se tornou sua marca pessoal e ali tudo era superlativo: o número de objetos utilizados, as ações repetitivas, as séries, a rapidez da execução, o exercício irônico ao nomear os trabalhos etc.

O modo como Arman incorporava os objetos aos seus trabalhos nunca foi um simples exercício de apropriação e apresentação porque, como escreve Catherine Francblin: “os objetos falam [...]. Ainda é necessário levá-los a deixar o silêncio, quer dizer, fazê-los passar por um mínimo de tratamento favorecendo a expressão deles." ${ }^{142}$ Para Arman, não era possível devolver o objeto para o real da mesma maneira como o havia encontrado, pois, segundo Francblin: "se for mesmo evocador, um objeto deve ser preparado, provocado e constrangido a se revelar" 143 .

$\mathrm{O}$ artista se afastava ainda mais da ideia de humanização do objeto quando falava que sua ideia de comprimir os objetos em caixas cobertas por Plexiglas e expô-las na vertical objetivava transformar o aglomerado de objetos em um padrão uniforme e plano. Agora, cada objeto funcionaria como o ponto de uma granulação que cobriria toda a tela - o equivalente a pensar no ponto de uma retícula numa página impressa, ou, num pixel de uma tela de computador - para compor uma abstração visual de um único objeto, como Arman explica num texto de 1961:

[...] o objeto não é escolhido em função de critérios dadaístas ou surrealistas: não se trata aqui de descontextualizar um objeto de seu substrato utilitário, industrial ou outro qualquer para dá-lo, por uma escolha de apresentação ou uma inclinação do seu aspecto, uma determinação completamente oposta à sua; por exemplo: antropomorfismo, analogia, reminiscências, etc., mas, muito pelo contrário, é questão de recontextualizá-lo nele mesmo, em uma superfície sensibilizada $x$ vezes pela sua presença duplicada; lembremo-nos da frase histórica: mil metros quadrados de azul são mais azuis que um metro quadrado de azul, eu digo então que mil conta-gotas são mais conta-gotas que um único conta-gotas.

Além disso, nessas superfícies, eu digo mesmo superfícies, pois mesmo nas minhas composições volumétricas, minha vontade é sempre mais pictórica que

${ }^{142}$ Les objets parlent [...]. Encore faut-il les amener à sortir de leur silence, c'est-à-dire leur faire subir un minimum de traitement favorisant leur expression. FRANCBLIN. Les Nouveaux Réalistes, 1997, p. 90.

${ }^{143}$ [...] si évocateur soit-il, un objet doit être apprêté, provoqué et contraint de se révéler. Ibidem, p. 91. 
escultórica, quer dizer que eu desejo ver minhas proposições tomadas pela ótica da superfície mais que uma realização em três dimensões. Portanto, nessas superfícies, a escolha de um único elemento resulta numa proclamação tanto monotípica quanto plural pelo seu número [...].

O lado obsessivo e articulável da multiplicidade de um objeto faz dele algo semelhante à granulação unida, expressão da consciência coletiva desse mesmo objeto. $^{144}$

No caso das acumulações de Arman, a repetição do objeto na composição de um padrão não indica apenas a sua intensificação, ela também simula o próprio processo industrial de fabricação do objeto, como afirma Arman no mesmo texto de 1961: "Esse procedimento de trabalho tem relação com os métodos atuais: automação, trabalho em cadeia e também o descarte em série, criando estratos e camadas geológicas plenas de toda a força do real." ${ }^{145} \mathrm{O}$ objeto aqui se faz "coisa' de duas maneiras: pelo objeto fantasiado - fusão de fragmentos de objeto - e por aquilo que nesses objetos é pura matéria - destroços de exobjetos, puro refugo, lixo urbano.

A obra Malheur aux barbus [Azar dos barbudos] de Arman (fig. 1) é um exemplo típico dos trabalhos que compõe a primeira fase da série Acumulações, executadas na década de sessenta ${ }^{146}$ : ela contém um grande número de exemplares de um mesmo tipo de objeto do cotidiano, comprimidos em uma caixa coberta por uma placa de Plexiglas e apresentada na vertical, na forma de uma vitrine. O que também é padrão nesses trabalhos é a presença de um título que não trata exatamente da classificação dos objetos amontoados, nem de um objeto em particular, mas que poderá, ou não, ajudar a identificá-los. Curiosamente, o título do

144 [...] l'objet choisi ne l'est pas en fonction des critères dada ou surréalistes: il ne s'agit pas là de décontextualiser un objet de son substrat utilitaire, industriel ou autre pour lui donner par un choix de présentation ou une inclinaison de son aspect, une détermination tout autre que la sienne propre; par exemple: anthropomorphisme, analogie, réminiscences, etc., mais il est question bien au contraire de le recontextualiser en lui-même dans une surface sensibilisée x fois par sa présence dupliquée; rappelons la phrase historique: mille mètres carrés de bleu sont plus bleus qu'un mètre carré de bleu, je dis donc que mille compte-gouttes sont plus compte-gouttes qu'un seul compte-gouttes. / De plus, dans ces surfaces, je dis bien surfaces car même dans mes compositions volumétriques, ma volonté est toujours picturale plus que sculpturale, c'est-à-dire que je désire voir mes propositions prises dans l'optique d'une surface plus que d'une réalisation en trois dimensions. Dans ces surfaces donc, l'élément unique dans son choix se trouve être une proclamation monotypique bien que plurale par son nombre [...].

Le côté obsessionnel et profératoire de la multiplicité d'un objet le rend pareil à une granulation unie, expression de la conscience collective de ce même objet. ARMAN. Réalisme des accumulations. (1961). In: Arman. 2010, p. 251.

${ }^{145}$ Ce procédé de travail est en corrélation avec les méthodes actuelles: automation, travail à la chaîne et aussi mise au rebut en série, créant des strates et des couches géologiques pleines de toute la force du réel. Ibidem.

${ }^{146} \mathrm{O}$ artista continuaria a produzir Acumulações ao longo de toda a sua carreira, concomitantemente a outras séries como, por exemplo: Poubelles [Lixeiras] - acumulação de detritos; Portrait-robots [Retratos falados] - acumulação de objetos pertencentes a uma única pessoa; Colères [Cóleras] - objetos, móveis, carros, apartamentos, etc., destruídos; Combustions [Combustões] - objetos, móveis carbonizados; Coupés [Cortes] - objetos fatiados etc. 
trabalho escolhido por Arman era o mesmo de uma série cômica radiofônica de grande sucesso dos anos cinquenta ${ }^{147}$ (fig. 2) e que havia se transformado em história em quadrinho com o título Signé Furax ${ }^{148}$ [Assinado: Furax]. As duas séries contavam a história do comissário Socrate e dos detetives 'Black and White' que perseguiam Edmond Furax, perigoso sequestrador de barbudos parisienses.

Se num primeiro momento, Malheur aux barbus de Arman pode ter tido um sentido cômico por apresentar o que poderia ser o espólio dos barbudos mortos por Furax, muito rapidamente o cômico se transformaria em irônico e se aproximaria do trágico, primeiro, em função das outras séries executadas por Arman - de caráter mais crítico e agressivo -, e segundo, em função de novas referências que o trabalho desse artista suscitava ${ }^{149}$.

Ainda que pertençam a uma mesma categoria, os objetos reunidos na acumulação de Arman não são todos iguais e também não se encontram nas mesmas condições: alguns parecem conservados, mas vários apresentam desgastes e outros se resumem ao que parece ser apenas uma ou outra parte do objeto. A dificuldade de identificação do tipo de objeto - e, portanto, da sua funcionalidade -, a impossibilidade de ter-se acesso físico a eles e a condição de desgaste/dano/abandono desses objetos acaba por caracterizá-los como coisas, no sentido do que está ‘aquém do objeto’ (Cf. item 1.1.2.).

${ }^{147}$ Entre 1951 e 1952, Francis Blanche (1921-1974) e Pierre Dac (1893-1975) criam e apresentaram um seriado cômico radiofônico de grande sucesso chamado Malheur aux barbus. Disponível em: <http://claudemesplede.com/2009/02/pierre-dac-roi-du-feuilleton-loufoque/>. Acesso em 29 set. 2011. Agradeço essa indicação a Ana Amélia Barros Coelho.

${ }^{148}$ Entre 1956 e 1960, a antiga série Malheur aux barbus voltou para o rádio com o nome de Signé Furax [Assinado: Furax], sendo também transformada em tiras cômicas desenhadas por Henry Blanc (1921) e publicadas diariamente no France-Soir entre 1957 e 1960. Disponível em: <http://www.coolfrenchcomics.com/furax.htm. Acesso em 29 set. 2011.

${ }^{149} \mathrm{O}$ exercício da citação que traz para as artes visuais referências vindas de mídias voltadas à cultura popular como a TV, o rádio, a publicidade e as histórias em quadrinho, ficará mais evidente a partir da produção dos artistas ligados à Arte Pop, como será o caso de parte da obra de Joe Brainard, artista cuja produção será abordada no próximo capítulo. 


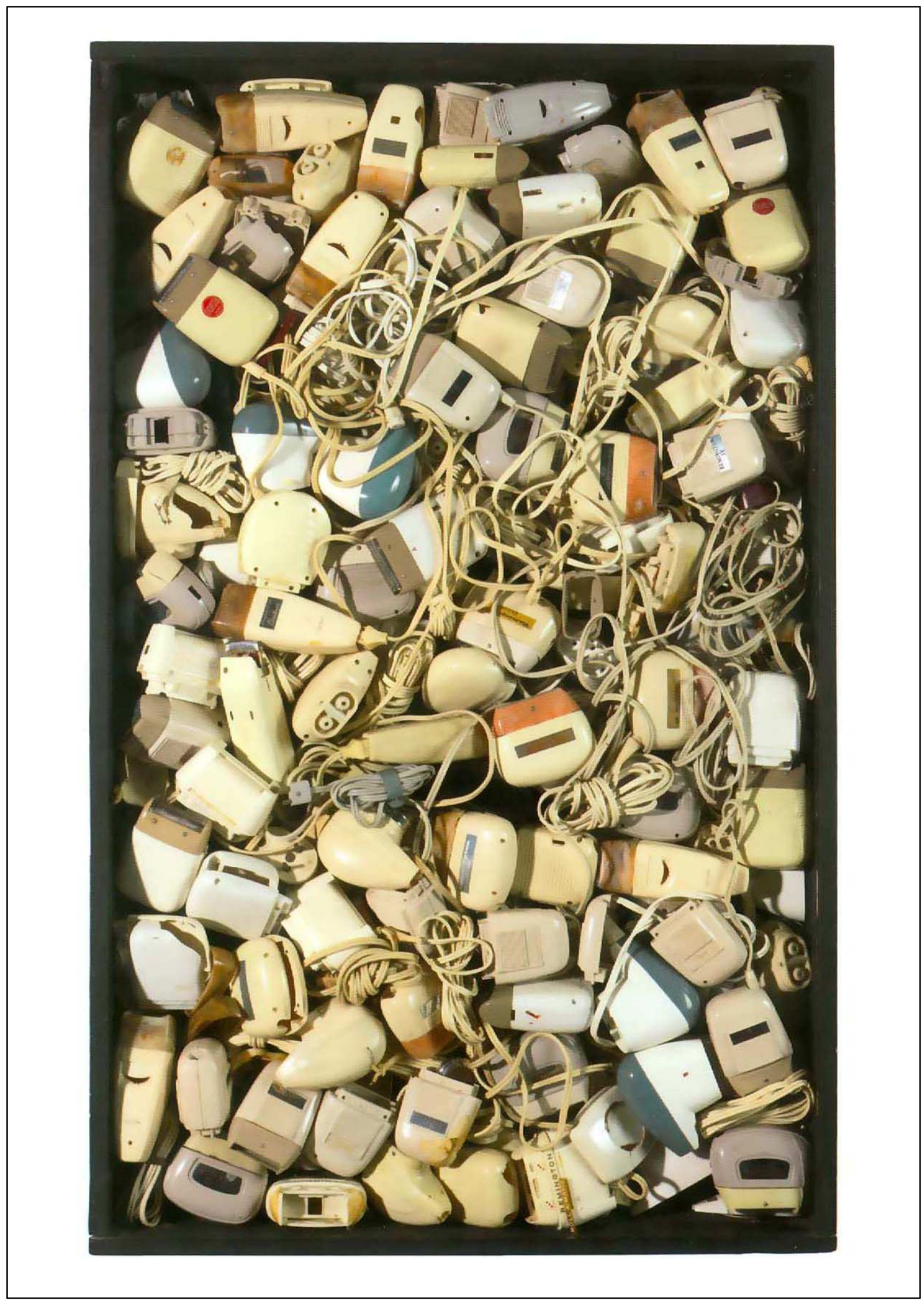

Figura 1 - Arman. Malheur aux barbus [Azar dos barbudos], (1960). Acumulação de barbeadores elétricos em caixa de madeira e Plexiglas, $101 \times 60,5 \times$ [?] $\mathrm{cm}$. 
Pelo tipo de objeto - um barbeador -, pela quantidade inúmeros -, e pelo estado em que se encontram - com marcas de usura -, o trabalho de Arman remete imediatamente o observador de Malheur aux barbus a outra forma coletiva que seria a própria razão de ser desses exemplares: os barbudos do título. Sem passado, sem justificativa e sem futuro, a maneira como Arman apresenta esses 'objetos defeituosos' configura um estado permanente de imobilidade, impedimento, inutilidade e falta, que parece fazer referência a uma morte - não das coisas que permanecem ali, observando e sendo observadas,

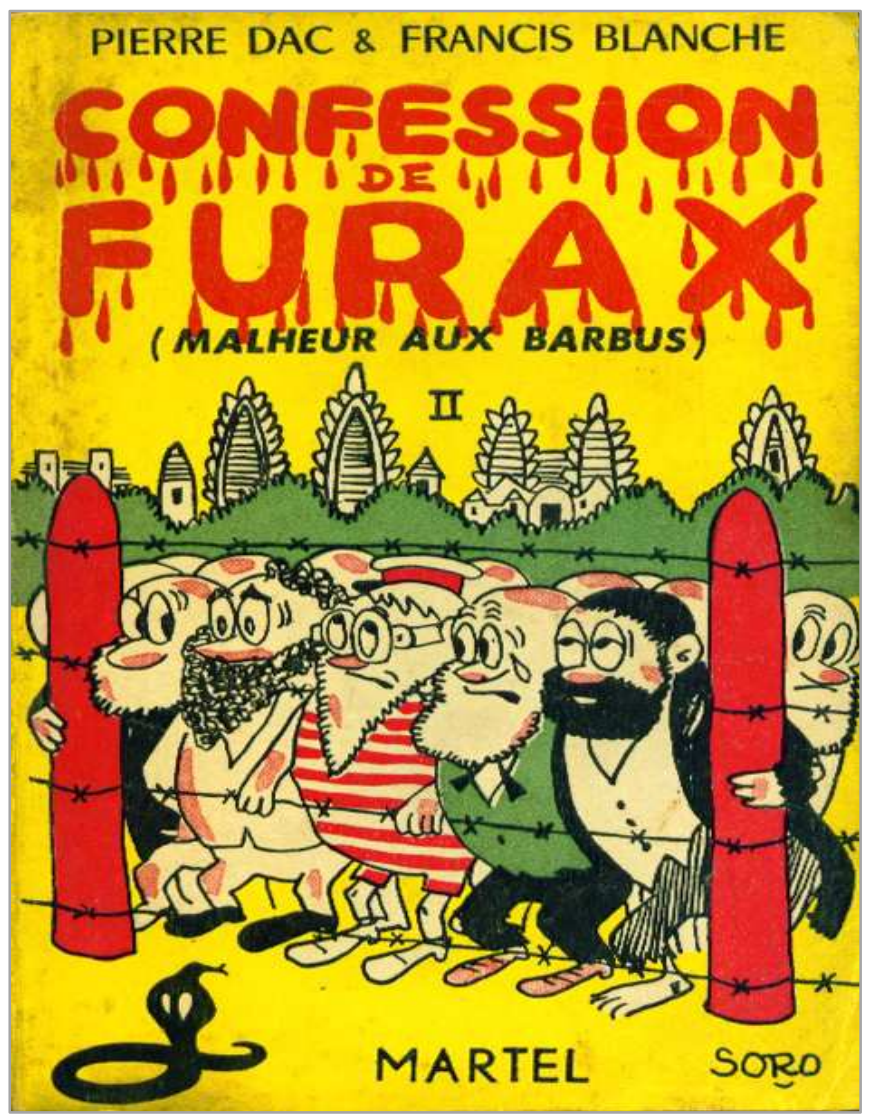

Figura 2 - Pierre Dac, Francis Blanche. Confession de Furax [Confissão de Furax], (Malheur aux barbus), vol. 2, 1952. Texto da série radiofônica.

mas de uma coletividade que dava sentido a elas. Mas esses objetos não são pura negatividade e as marcas de usura também podem sugerir que eles corresponderam às expectativas dos seus usuários, foram exaustivamente empregados e que houve entre os dois - objeto e usuário momentos de felicidade (sem que saibamos se a razão para isso foi de ordem prática/funcional, ou de simples ordem consumista).

Outra dualidade importante que Catherine Francblin ${ }^{150}$ reconhece como perturbadora nessa Acumulação está na diferença entre o espírito sistemático e artificial que concebe o conjunto e o desarranjo humano e casual do amontoado interno dos elementos.

Outros tipos de coletividades aparecem indicados em outras acumulações do artista, como, por exemplo: La vie à pleines dents [A vida cheia de dentes] (1960): acumulação de dentaduras - referência aos idosos; Home, Sweet Home [Lar, Doce Lar] (1960): acumulação de máscaras de gás - referência aos soldados; e Madison Avenue (1962): acumulação de sapatos femininos - referência às mulheres.

\footnotetext{
${ }^{150}$ FRANCBLIN. Les Nouveaux Réalistes, 1997, p. 92.
} 


\subsection{As coisas como 'o aquém' e 'o além' do objeto} As coisas nos descrevem. Podemos descrever os seres através dos objetos,
através do ambiente que os circunda e a maneira pela qual se movimentam nesse
ambiente. ${ }^{151}$

Georges Perec

Para entender a relação do homem com as coisas no interior das obras de Perec e Arman, é necessário tocar em algumas noções gerais de como isso se dá na sociedade contemporânea. $\mathrm{O}$ objeto contemporâneo é fundamentalmente um produto industrializado e, enquanto circula pelas instâncias mais amplas da sociedade (indústria, comércio etc.), ele é um mediador impessoal - resultado de uma infinidade de forças que agem sob o comando de uma figura institucional (uma marca, por exemplo), com a finalidade de servir a um coletivo de usuários anônimos. Isso é diferente do que ocorria com o objeto artesanal - mediador personalizado -, resultado de um estreitamento de relações entre o produtor e seu cliente.

Violette Morin ${ }^{152}$, numa publicação que, na década de sessenta, reuniu um grupo importante de autores para pensar o objeto, propõe por meio de uma esquematização bastante sucinta dividir os objetos do cotidiano em dois grandes grupos: o primeiro ela chama de 'objeto biográfico' e o segundo de 'objeto protocolar'. Se o objeto biográfico faz parte de uma relação que se prolonga no tempo e está ligada a certas vivências do usuário, o objeto protocolar é um objeto circunstancial, que serve a uma necessidade essencialmente prática. Todo objeto industrializado é por natureza protocolar e o fato dele se transformar em biográfico, ou não, dependerá principalmente da maneira como o indivíduo lida com ele. $\mathrm{O}$ exercício puro e simples que põe em prática a funcionalidade do objeto não faz dele um objeto biográfico: não é porque uma cafeteira preparou cafés ao longo de 30 anos que ela passa a ser tida como um objeto mais biográfico do que outra recém adquirida. $\mathrm{O}$ 'biográfico' do objeto independe das suas características físicas, funcionais e de durabilidade.

Na relação do sujeito com o objeto biográfico, Violette Morin reconhece um percurso e um espelhamento no qual tanto o objeto quanto o usuário vivem em sincronia, transformando-se em testemunhas de um processo de envelhecimento mútuo. Como duplicadores da vivência do usuário, os objetos biográficos contribuiriam para ocupar e limitar o espaço concreto do usuário, marcar seu habitat, aprofundar seu enraizamento e

${ }^{151}$ Les choses nous décrivent. Nous pouvons décrire les êtres à travers les objets, à travers le milieu qui les entoure et la manière dont ils se déplacent dans ce milieu. PAWLIKOWSKA. Entretien Georges Perec / Ewa Pawlikowska. (1981). In: PEREC. Entretiens et Conférences, 2003b, p. 203.

${ }^{152}$ MORIN. L'objet biographique. In: Communications, 1969, pp. 131-139. 
determinar os limites de segurança do viver abrigado, ou seja, o ambiente onde se desenvolve a intimidade ativa do usuário.

Um exemplo de como o objeto biográfico incorpora o tempo e acompanha os passos do seu proprietário pode ser dado de maneira singela e breve pelo poema Gesso de Manuel Bandeira $^{153}$ :

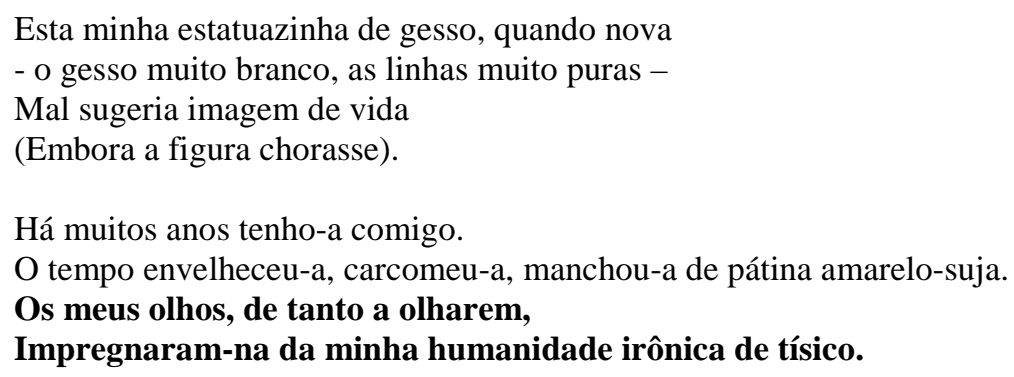

Um dia mão estúpida

Inadvertidamente a derrubou e partiu.

Então ajoelhei com raiva, recolhi aqueles tristes fragmentos, recompus a figurinha que chorava.

E o tempo sobre as feridas escureceu ainda mais o sujo mordente da pátina...

\section{Hoje este gessozinho comercial}

É tocante e vive, e me fez agora refletir

Que só é verdadeiramente vivo o que já sofreu.

O 'gessozinho comercial' de Bandeira, comum e banal, se humaniza - contaminado pelos olhos irônicos do poeta tísico -, e sofre agora tanto quanto ele: se a figurinha antes chorava por chorar, agora, marcada pelas vicissitudes da vida do seu proprietário/usuário/companheiro - a queda, o dano físico, as marcas do tempo -, passou a ter motivos de sobra para chorar de verdade e por dois. O poema de Bandeira é um exemplo para o que Violette Morin vê no objeto biográfico: a projeção das experiências vividas pelo usuário e, exatamente por isso, reveladoras de uma identidade. Como duplicadores da vivência do usuário, esses objetos contribuem para ocupar e limitar o espaço concreto do usuário, marcar seu habitat, aprofundar seu enraizamento e determinar os limites de segurança do viver abrigado - "um lugar retraído do resto do mundo" ${ }^{154}$, seu Umwelt ${ }^{155}$, sua "cotidianidade feito coisa" 156 .

${ }^{153}$ BANDEIRA. Gesso. In: Estrela da vida inteira, 1986, pp. 87-88.

${ }^{154}$ [...] un lieux retranché du reste du monde [...]. MORIN. L'objet biographique. In: Communications, 1969, p. 136.

${ }^{155}$ UMWELT: este é um conceito importante que acompanha as ideias de Martin Heidegger (1889-1976) em Ser e Tempo. Traduzido geralmente como 'meio ambiente', Roy Elveton esclarece que se trata de tudo que cerca e diz respeito ao indivíduo em sua vida cotidiana, no que há ali de acessível e necessário - incluindo aí equipamentos e ferramentas - para o desempenho das suas atividades normais do dia a dia. In: ELVETON, 
O que o objeto biográfico tem de poroso e absorvente na relação com o usuário, o objeto protocolar tem de liso e refratável. O objeto protocolar deve servir a uma necessidade específica e qualquer tentativa de acalentá-lo não melhora em nada o seu desempenho. Esse é um objeto que não lança raízes no espaço do usuário porque deverá deixar seu posto com a mesma rapidez com que surgiu e/ou desempenhou suas funções. Normalmente, é um objeto tecnológico, mas também pode ser um 'objeto da moda', que deve ser usado até o momento que surge outro modelo mais potente e/ou atualizado e/ou valorizado, não podendo ser acumulado porque só amplia um sentido de desconforto para o usuário: é anacrônico e assinala uma defasagem entre o que se tem e o que se quer para acompanhar uma necessidade que vai sendo incrementada por um sistema no qual o usuário raramente tem o poder/oportunidade de interferir. Se o destino do objeto biográfico é ser usado e envelhecer com o usuário, o objeto protocolar se deteriora, se esgota, se torna obsoleto e deve ser rapidamente trocado - como bem indica a obra de Arman.

Se essas duas denominações servem para tratar da relação do objeto com o indivíduo, agora é a vez de especificar o que se passa do indivíduo para com seus objetos (biográficos e protocolares). Abraham Moles ${ }^{157}$ subdivide o período dessa relação - que chamarei aqui de 'Escala de Vida dos Objetos' -, em sete etapas que se sucedem na seguinte ordem: (1) o desejo, (2) a aquisição, (3) o descobrir, (4) o afeiçoar-se, (5) o habituar-se, (6) a manutenção e (7) a troca. Para tornar mais claro o que se passa com os objetos utilizados por Arman eu faço uma alteração no nome da última etapa definida por Moles e ainda acrescento mais uma, ficando assim: (7) a morte (que é a perda definitiva do objeto e que pode ocorrer pelo seu descarte ou pela sua troca) e (8) a lembrança.

A escala só seria utilizada na sua amplitude maior de etapas se o tipo de objeto estudado fosse o biográfico, como em nenhuma das obras estudadas pela pesquisa existem dados que permitam pensar o que se passa em cada uma das etapas intermediárias, o interesse aqui deverá se limitar aos extremos da escala. Se em Les choses, as relações com os objetos estão basicamente estagnadas na primeira etapa - a do desejo -, quando ainda não foi possível estabelecer uma experiência real particular com eles, em Malheur aux barbus, de Arman, a relação direta com o objeto também não se efetiva porque está proibida, já que os objetos

Roy. Umwelt. The Literary Encyclopedia. First published 22 April 2005. The Literary Encyclopedia. Disponível em: $\lfloor$ http://www.litencyc.com/php/stopics.php?rec=true\&UID=1542>. Acesso em 04 out. 2011.

${ }^{156}$ [...] sa quotidienneté faite chose [...]. MORIN. L'objet biographique. In: Communications, 1969, p. 137.

${ }^{157}$ MOLES Théorie des objets, 1972, p. 96. 
estão fechados nas caixas cobertas por vidro, e o que se dá a experimentar é a etapa (7), a da morte do objeto, quando só cabe ao indivíduo velar pelos objetos dos outros.

\subsubsection{Perec e a aurora do desejo}

[...] sempre haverá mais coisas num cofre fechado do que num cofre aberto. A verificação faz as imagens morrerem. Imaginar será sempre maior que viver.

Gaston Bachelard ${ }^{158}$

Ainda que inicialmente o leitor possa tomar os personagens de Les choses como preguiçosos ou incapazes por não investirem de maneira mais objetiva na realização de seus sonhos, a frase de Bachelard - "imaginar será sempre maior que viver" - ressoa com força nas atitudes e nos esforços periféricos e frágeis dos personagens - e que não seriam apenas deles, mas de todos aqueles que se deixam levar pelas fantasias propostas pelo universo da publicidade e do consumo. Era nesse universo dos possíveis que Jérôme, Sylvie e seus amigos viviam e onde não precisavam se preocupar com restrições, limites ou constrangimentos, podendo fazer, comer, beber, ler, escrever, ver e rever o que pretendiam, como aponta o narrador: "E às vezes, mergulhando mais e mais nesses sonhos coletivos, sem se preocupar em despertar, mas se relançando neles sem cessar com uma cumplicidade tácita, eles acabavam por perder todo contato com a realidade." 159 (Lc, p. 55).

Maneira curiosa de o autor explorar o 'realismo': tratando das imagens de quem vive sonhando e não traz os pés no chão. É por tudo isso que a relação do casal de personagens com os objetos permanece o tempo todo na primeira etapa da escala proposta por Moles: (1) o desejo. Mas não é que eles estejam ali como estariam outros indivíduos: tomando um impulso para se lançar para a segunda etapa da escala, ou seja: a (2) a aquisição -, os personagens de Perec parecem tirar prazer por estar no estágio mais inicial dessa etapa, e que Baudrillard identifica como aquilo que a publicidade oferece: uma 'aurora de desejo', um canal de forças

\footnotetext{
${ }^{158}$ BACHELARD. A poética do espaço, 2000, p. 100.

${ }^{159}$ Et parfois, se plongeant de plus en plus dans ces rêves collectifs, sans chercher à s'en éveiller, mais les relançant sans cesse avec une complicité tacite, ils finissaient par perdre tout contact avec la réalité.
} 
que fantasiam não apenas o objeto, como todas as possibilidades de prazer que podem advir dessa relação.

Ao tratar da publicidade em Le Système des Objets [O Sistema dos Objetos], Baudrillard explica que: "os signos publicitários nos falam dos objetos, mas sem explicá-los em vista de uma práxis [...]: de fato, eles direcionam aos objetos reais como a um mundo ausente. Eles são literalmente 'legendas', quer dizer que eles estão ali desde o início para serem lidos." ${ }^{160}$ Como abstrações, esses signos têm o papel de assinalar a falta do que designam e por causa disso a leitura está organizada num 'sistema específico de satisfação' onde tudo contribui para um sentido de prazer e realização, mas que ao mesmo tempo deve explicitar a falta do real - o que é um motivo perpétuo de frustração. A imagem publicitária, avisa Baudrillard, cria um vazio intencional.

Como atrativo maior para convencer o consumidor a aceitar o jogo de imagens da publicidade, o objeto de consumo na forma de legenda dissipa a 'polissemia angustiante do mundo' simplificando a complexidade das relações e reduzindo ao mínimo o número de elementos participantes. O jogo do consumo é ardiloso e sedutor, fácil de entrar e difícil de sair, onde práticas sociais e mitológicas se misturam com tanta intensidade que do objeto mesmo só reconhecemos o que nele é 'coisa' porque todo o resto não é dado pela materialidade do objeto, mas pelos sentidos (segredos?) que passam a cercar um 'nome' como, por exemplo, o sofá Chesterfield, um dos sonhos de consumo do casal sonhador de Les choses ${ }^{161}$. É isso o que configura então o 'objeto de desejo': uma coisa que tem por base uma fantasia e por qualidade um prazer, onde não existe qualquer materialidade ou possibilidade de comprovação, já que toda a relação com esse objeto se efetiva no campo das imagens e não do real.

${ }^{160}$ Les signes publicitaires nous parlent des objets, mais sans les expliquer en vue d'une praxis [...]: en fait, ils renvoient aux objets réels comme à un monde absent. Ils sont littéralement "légende", c'est-à-dire qu'ils sont d'abord là pour être lus. BAUDRILLARD. Le système des objets, 1981, p. 208.

${ }^{161}$ Ao longo do livro de Perec o leitor entra em contato com uma grande quantidade de nomes que designam objetos, lugares, profissões, obras de arte, autores, acontecimentos, endereços, etc., que são, muitas vezes, verdadeiros enigmas quanto ao que significam. O estranhamento talvez não fosse tão grande para os leitores franceses no início dos anos sessenta, quando 'as coisas' do título serviam para indicar principalmente um agrupamento de objetos heterogêneos que fazia parte do dia-a-dia do francês contemporâneo à narrativa. Outros leitores, afastados daquele contexto, encontrariam dificuldades para entender o que aqueles nomes designavam exatamente. Prova disso é que em 1969 (mesmo ano do lançamento do livro no Brasil), é publicada em Moscou uma versão do livro - em francês - acompanhada de uma longa sequência de notas explicativas que parecem compor uma 'enciclopédia' de Les choses. Cf. GROMOVA, T. Notes. In: PEREC. Les choses, 1969, pp. 156-178. 
Jean Baudrillard ${ }^{162}$ também explica que, na sociedade de consumo, não são os objetos materiais que são consumidos, eles são apenas o que efetiva a necessidade e a satisfação, pois o consumo se caracteriza por ser 'uma atividade de manipulação sistemática de signos'. Na transformação do objeto em signo, o que muda não é apenas o estatuto do objeto, que perde sua materialidade, muda também a relação do homem com os objetos, visto que ela se torna abstrata e deixa de ser vivida: o que é consumido aqui não é o objeto, mas a relação. Como produção abstrata tudo pode ser vendido, comprado, propagandeado, valorizado ou desqualificado e, ainda segundo Baudrillard: "hoje todos os desejos, os projetos, as exigências, todas as paixões e todas as relações se abstraem (ou se materializam) em signos e em objeto para serem compradas e consumidas" 163.

O desejo é a grande força de mobilização que incita imagens de felicidade e conforto presentes em Les choses e é uma força que movimenta a narrativa. Se no início do livro, o uso do futuro do pretérito pode ser identificado com a 'aurora do desejo' - desejo que deverá ser constantemente frustrado ao longo da narrativa -, no final do livro, quando a história passa a ser contada no futuro, já se pode pensar em um desejo em vias de realização que, se é que vai se realizar, deverá se realizar mais à frente, ou seja, fora do tempo/espaço do livro.

Como exemplo de uma linguagem sedutora que introjeta mensagens cifradas ao longo da narrativa, insinuando a presença de um mito, está, por exemplo, a presença marcante de elementos referentes à cultura anglo-saxônica, e que surgem como algo normal, corriqueiro mesmo, como, por exemplo, a epígrafe do livro: uma citação que Perec identifica apenas como sendo de Malcolm Lowry ${ }^{164}$, em inglês:

Incalculable are the benefits civilization has brought us, incommensurable the productive power of all classes of riches originated by the inventions and discoveries of science. Inconceivable the marvelous creations of the human sex in

${ }^{162}$ BAUDRILLARD. Le système des objets, 1981, p. 233.

163 [...] aujourd'hui tous les désirs, les projets, les exigences, toutes les passions et toutes les relations s'abstraient (ou se matérialisent) en signes et en objet pour être achetées et consommées. Ibidem, p. 234.

${ }^{164}$ Malcolm Lowry (1909-1957): escritor inglês, autor de À sombra do vulcão (1947) - livro de onde Perec retirou a citação. Perec possuía em sua biblioteca a edição inglesa desse livro: Under the volcano, Penguin, 1963. Cf. Le Catalogue de la Bibliothèque de Georges Perec. Disponível em: <http://associationgeorgesperec.fr/spip.php?rubrique13>. Acesso em 21 set. 2011.

Essa simples citação guarda inúmeras referências dispostas em várias camadas de significados - exercício de intertextualidade que Perec exploraria sobremaneira em suas obras - e que passam despercebidas à maioria dos seus leitores. Perec já havia utilizado a mesma citação no início de um artigo publicado em Partisans Cf. PEREC. L'univers de la science-fiction. (1963). In: L. G., 1992 p. 115. A citação do livro de Lowry, segundo Bellos, trata de uma paródia de Homero que o personagem do livro de Lowry (o cônsul) ouve em espanhol (como é falado no México) pelo rádio, e tenta traduzir rapidamente para o inglês - daí certo estranhamento no texto. Cf. BELLOS. Georges Perec, 1994, p. 325. 
order to make men more happy, more free, and more perfect. Without parallel the crystalline and fecund fountains of the new life which still remains closed to the thirsty lips of the people who follow in their griping and bestial tasks. ${ }^{165}$ (Lc, p. 7).

Depois vão surgindo objetos, autores, modos de vida, costumes, de uma vida que poderia ser:

- mais requintada: "Um grande leito inglês ocuparia todo o fundo." ${ }^{166}$ (Lc, p. 11);

- mais elegante: “[...] um par de navalhas inglesas e seu estojo de couro verde [...]; a cama seria coberta por um manto escocês." ${ }^{167}$ (Lc, p. 12);

- mais prática: "Eles se entusiasmavam por uma mala - dessas malas minúsculas, extraordinariamente chatas, em couro preto ligeiramente granulado, que se vê na vitrine nas lojas da Madeleine, e que parecem concentrar nelas todos os prazeres presumidos em viagens relâmpago, a Nova York ou a Londres." ${ }^{168}$ (Lc, pp. 2324);

- mais culta: “[...] eles assimilaram o vocabulário e os sinais, os truques que faziam bem: [...] uma certa maneira de citar, nos momentos oportunos, Wright Mills, William Whyte, ou, melhor ainda, Lazarsfeld, Cantril ou Herbert Hyman, dos quais eles não tinham lido nem três páginas." ${ }^{169}$ (Lc, p. 32);

- mais atualizada: "Eles voltavam da rue Mouffetard, todos juntos, braços carregados de mantimentos [...], por cestos cheios, de vinho, de porto, de água mineral, de Coca-Cola." ${ }^{170}$ (Lc, p. 57);

${ }^{165}$ Incalculáveis são os benefícios que a civilização nos trouxe, incomensurável é o poder produtivo de todos os tipos de riquezas gerados pelas descobertas e invenções da ciência. Inconcebíveis as maravilhosas criações do sexo humano para fazer os homens mais felizes, mais livres e mais perfeitos. Sem paralelos as fontes cristalinas e fecundas da nova vida ainda fechadas aos sedentos lábios do povo que permanece submisso a tarefas bestiais e ingratas. LOWRY. À sombra do vulcão, Trad. Leonardo Fróes, 1992, p. 331.

${ }^{166}$ Un grand lit anglais en occuperait tout le fond.

${ }^{167}$ [...] une paire de rasoirs anglais et leur fourreau de cuir vert [...]; le lit serait recouvert d'un plaid écossais.

${ }^{168}$ Ils s'enthousiasmaient pour une valise - ces valises minuscules, extraordinairement plates, en cuir noir légèrement grenu, que l'on voit en vitrine dans les magasins de la Madeleine, et qui semblent concentrer en elles tous les plaisirs supposés des voyages éclair, à New York ou à Londres.

${ }^{169}$ [...] ils assimilèrent le vocabulaire et les signes, les trucs qui faisaient bien: [...] une certaine manière de citer, aux moments opportuns, Wright Mills, William Whyte, ou, mieux encore, Lazarsfeld, Cantril ou Herbert Hyman, dont ils n'avaient pas lu trois pages.

${ }^{170}$ Ils revenaient de la rue Mouffetard, tous ensemble, les bras chargés de victuailles [...], par casiers entiers, de vin, de porto, d'eau minérale, de Coca-Cola. 
- mais civilizada: "Eles teriam gostado de viver na Inglaterra, onde a polícia tem a reputação de ser respeitosa com as pessoas." ${ }^{171}$ (Lc, p. 85);

- mais tradicional: "Depois eles voltariam para casa e preparariam para si chá com torradas, como os ingleses [...]." ${ }^{172}$ (Lc, p. 120).

Quanto ao tipo de objeto que predomina na narrativa, é o protocolar ${ }^{173}$ porque, como salienta Violette Morin ${ }^{174}$, ele deve servir a todos: ele é projetado de tal maneira que, ao se antecipar em tudo aquilo que pode oferecer de agradável e útil ao consumidor, faz crer que está cumprindo com todas as suas necessidades e anseios, tendo sido feito exatamente por isso e exclusivamente para esse consumidor.

Desfeito o encantamento, restam a matéria, a falência, a inadequação e a obsolescência apontadas pela obra de Arman.

${ }^{171}$ Ils auraient aimé vivre en Angleterre, où la police a la réputation d'être respectueuse de la personne humaine.

${ }^{172}$ Puis ils rentreraient, ils se prépareraient du thé et des toasts, comme les Anglais [...].

${ }^{173}$ Não é possível falar da presença de objetos biográficos em Les choses porque ali não há qualquer vestígio que permita pensar nas transformações e nas ligações pessoais dos personagens com seus objetos. Mesmo o portulano, que aparece em três situações distintas (Lc, pp. 9, 21 e 127), aparece apenas para marcar lugar e contribuir para compor o que Barthes chamou de 'efeito de real'. (Cf. item 3.1.2.).

${ }^{174}$ MORIN. L'objet biographique. In: Communications, 1969, p. 133. 


\subsubsection{Arman e a morte do objeto $(+)$}

Como já foi visto anteriormente, a última etapa da relação do indivíduo com o objeto enquanto ainda é possível contar com a sua materialidade -, é a 'morte' (provocada pela troca, descarte ou perda do objeto) (fig. 3).

O que Arman estava mostrando pela primeira vez era o resultado final de todo processo de industrialização: o futuro/destino de todo objeto. Mas nesse momento isso apenas começava a ser visível no ambiente urbano, ainda não era um problema e não tinha a mesma visibilidade das ofertas que enchiam lojas e supermercados. A proposta de Arman, como é assinalada por Catherine Francblin ${ }^{175}$ e Benjamin Buchloh ${ }^{176}$, era inquietante por misturar prazer com dor numa escala que ainda não havia sido explorada. Que o objeto com indícios de uso - índice de um contato humano e, portanto, de uma 'falta' -, já havia sido largamente explorado por muitos artistas, isso não era novidade, mas agregar a isso o valor da quantidade, da generalidade e do anonimato, isso era desestabilizador $^{177}$. Se

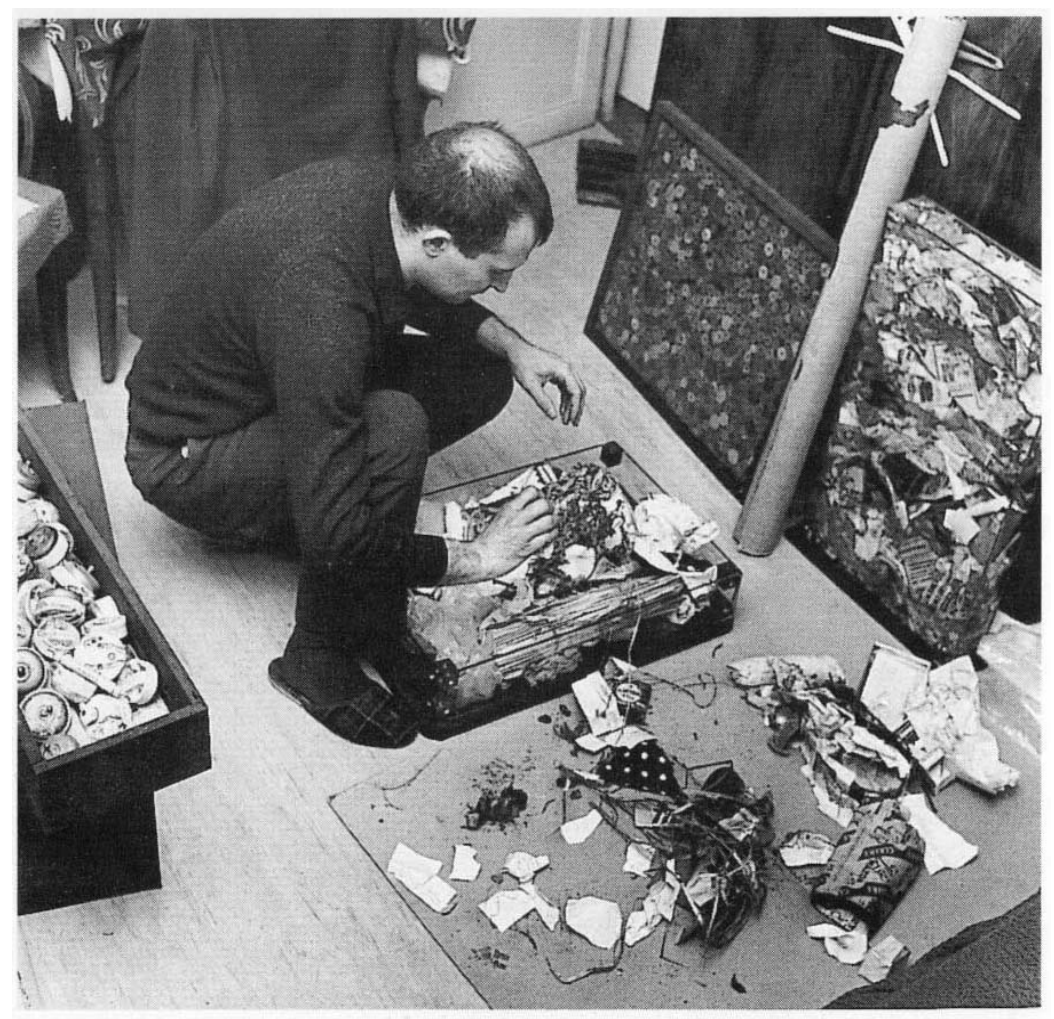

Figura 3 - Arman realizando Poubelle des Halles [A lixeira de Halles] (1961), tendo à esquerda uma caixa com acumulações.

\footnotetext{
${ }^{175}$ FRANCBLIN. Les Nouveaux Réalistes, 1997, pp. 91-92.

${ }^{176}$ BUCHLOH. Plenty or Nothing: from Yves Klein's le Vide to Arman's Le Plein. In: Premises, 1998, pp. 8699.

${ }^{177}$ Nos trabalhos da série Accumulations [Acumulações], feitos pelo agrupamento de um único tipo de objeto, não existem indicações que permitam ligar determinado objeto a um determinado indivíduo. Isso seria feito na série que Arman também iniciaria nos anos sessenta e que ele chamou de Portrait-robots [Retratos falados]. Ali seriam agrupados, de maneira desordenada e bastante condensada, objetos heteróclitos pertencentes a uma única pessoa como, por exemplo: Portrait-robot de Daniel Spoerri (1962), ou, Portraitrobot de Phillipe Durand-Durel (1965), e vários outros.
} 
havia no trabalho do artista algo de premonitório que sugeria às pessoas um novo olhar para o que se passava ao redor, percebendo assim o ritmo alucinado como os objetos do cotidiano começavam a ser descartados e substituídos (quer por melhorias tecnológicas, quer por defeitos técnicos, quer por imposições da moda e/ou caprichos particulares), havia também algo nos trabalhos de Arman que incitava as pessoas a buscar relações com algo que lhes era ainda muito próximo e que tinha a ver com impressões de quantidade e sofrimento: isso era encontrado nos números decorrentes da Segunda Guerra Mundial.

Dez anos após o final dessa tragédia, Alain Resnais lançou em 1955 o documentário Nuit et Brouillard [Noite e Neblina] (fig. 4) que, por meio do cinema, trazia imagens chocantes dos campos de concentração - espaço de segregação, sofrimento e morte -, que boa parte da população francesa e de outras nações ainda não conhecia. Essas imagens conferiam uma visibilidade e uma materialidade a algo que até aquele momento era puro silêncio e esquecimento, e que era representado por um único tipo de código: o numérico.

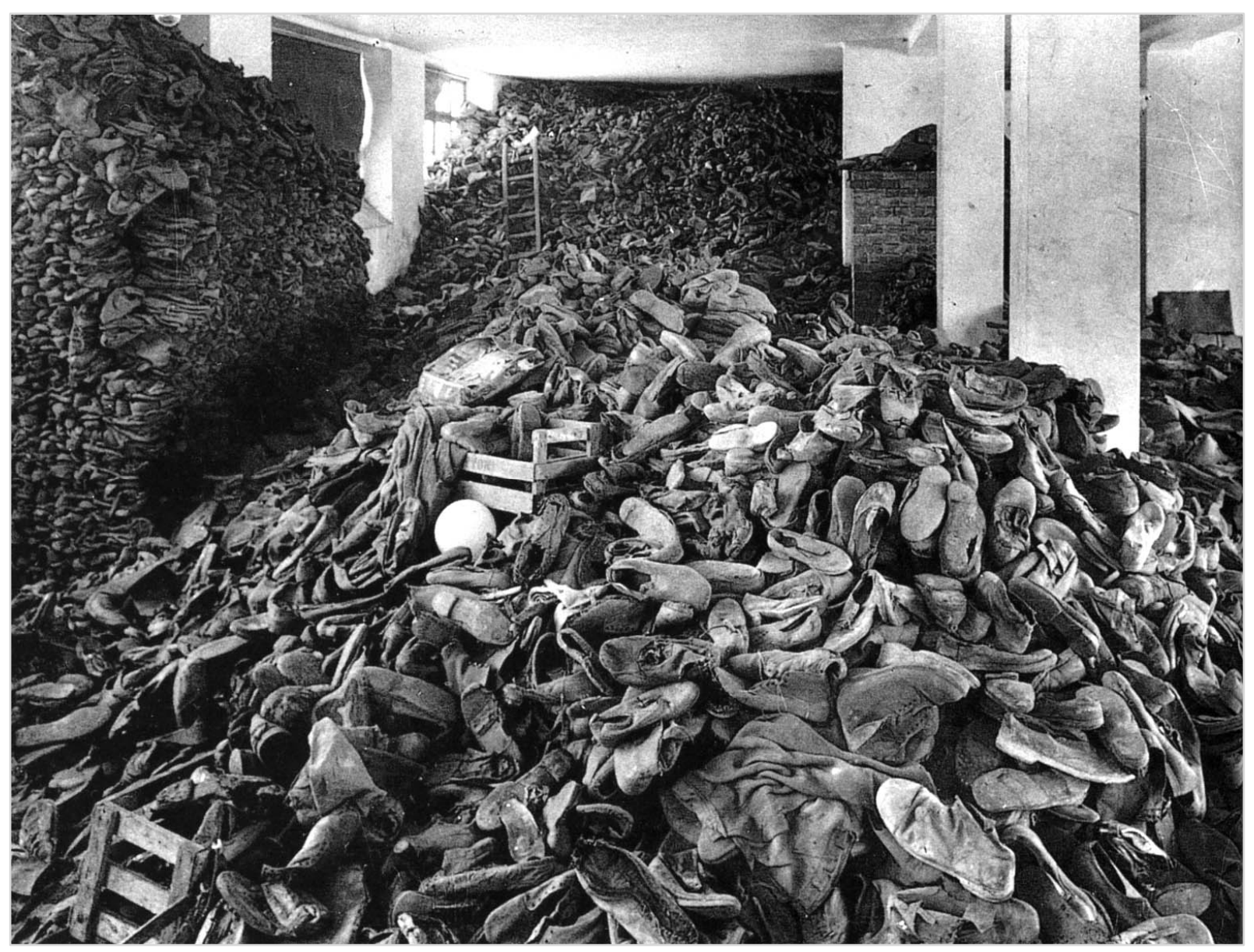

Figura 4 - Alain Resnais. Sapatos encontrados em um Campo de Concentração. Fotograma do filme: Nuit et brouillard (1955). 
O filme inicia apresentando o estado atual dos terrenos onde foram construídos alguns campos de concentração dando ênfase à vastidão desses espaços. Num segundo momento são apresentadas imagens do fluxo de pessoas que eram trazidas aos campos em vagões superlotados utilizados para o transporte de animais e mercadorias. Após uma narração que descreve o funcionamento dos campos e a relação desses espaços com as áreas ao redor onde 'a vida era normal e tudo transcorria em paz', começa a ser mostrado o que ocorria no interior desses campos: são imagens que surpreendem pelo desmesurado, pela desumanidade e pelo anonimato: os prisioneiros são identificados por números tatuados em seus braços. Multidões vão sendo mostradas numa escala decrescente de civilidade e humanidade: primeiro são cidadãos com estrelas bordadas nas roupas circulando pelas cidades ocupadas; depois são mostrados prisioneiros uniformizados no interior dos campos de concentração; após isso, os prisioneiros são homens e mulheres nus, muito magros e com as cabeças raspadas; até que, no momento derradeiro de (des)humanidade, são apresentados amontoados inacreditáveis de corpos degradados, de membros avulsos, de óculos, de pentes, de pincéis de barba, de tigelas, de roupas, de cabelos etc. Francblin assinala que Arman nunca chegou a mencionar esse filme ou a relacionar seus trabalhos ao que fora mostrado no documentário, explicando que sua obsessão por objetos e pelo exercício da quantidade era algo pessoal e familiar. Mas naquele momento, quando as imagens do documentário eram a própria expressão da quantidade, os objetos enclausurados de Arman, subtraídos de qualquer funcionalidade e configurados em imagens, entravam para o campo da transgressão (cf. item 1.1.2.), onde a relação/intermediação com o real tomava o que estava disponível naquele momento enquanto imagem emblemática e que poderia conferir sentido ao esforço do artista: o humor presente em Malheur aux barbus só amplificava a ironia do seu significado e um mal-estar. Com a continuação da obra de Arman, as imagens de acumulações ligadas aos campos de concentração dariam lugar a novas imagens que apontariam, indiscutivelmente, para outro tipo de degradação: a urbana. Ainda que as pessoas se esquecessem do Holocausto, dos barbeadores elétricos Remington 60, da Segunda Grande Guerra, a obra desse artista continuaria irradiando novas possibilidades de significação.

Quanto a Perec, ainda que existam em sua obra várias referências aos campos de concentração ${ }^{178}$, a referência que me parece mais marcante é quando Perec foi apresentado a essa realidade pela primeira vez. Ele relata isso na autobiografia de sua infância: $W$ ou le

\footnotetext{
${ }^{178}$ No livro La boutique obscure - 124 rêves [A loja escura - 124 sonhos) (1973), uma coleção de sonhos transcritos por Perec entre maio de 1968 e agosto de 1972, o primeiro e último sonhos trazem referências explícitas a campos de concentração. Cf. PEREC. La boutique obscure - 124 rêves, 1993.
} 
souvenir d'enfance [W ou a lembrança da infância] ${ }^{179}$ (1975). Perec tinha nove anos de idade e havia acabado de voltar a Paris para viver com a família da irmã de seu pai (ele ainda não sabia o que ocorrera com sua mãe - presa em 23 de janeiro de 1943 e deportada para o Campo de Concentração de Auschwitz-Birkenau). O relato de Perec é frio e distante, desprovido de qualquer emoção, indicando o distanciamento do menino em relação àquela realidade ainda distante. Naquele momento, o que chamava sua atenção (e ele continuará a ter olhos basicamente para isso) era o que lhe era próximo e imediato como, por exemplo, os detalhes insignificantes de uma região da cidade de Paris que ele ainda não conhecia:

[Dias depois de ter retornado a Paris, em 1945,] eu fui com minha tia ver uma exposição sobre os campos de concentração. Ela acontecia ao lado de La MottePicquet-Grenelle (nesse mesmo dia, eu descobri que existiam metrôs que não eram subterrâneos, mas aéreos). Eu me lembro das fotos mostrando as paredes dos fornos dilacerados pelas unhas dos sufocados por gás e de um jogo de damas fabricado com bolinhas de pão. ${ }^{180}$ (W, p. 215).

\subsection{O que não para de aumentar}

Segundo Catherine Francblin: "na acumulação o objeto desaparece como indivíduo em proveito da sua eclosão como espécie, da sua reaparição sob a forma universal de objeto genérico. Transformando o particular em geral, a acumulação é, portanto, uma operação de abstração." 181

Passados mais de cinquenta anos que Perec e Arman apresentaram suas obras, suas acumulações nunca deixaram de aumentar, mesmo depois de seus objetos terem ficado velhos e se tornado obsoletos. Depois de todas as inovações tecnológicas e de design, muito dificilmente alguém inteessado em novidades se sentiria atraído por um dos barbeadores de Arman, ou pelo sofá Chesterfield tão desejado por Jérôme e Sylvie. Mas existiam algumas

\footnotetext{
${ }^{179}$ Embora o tradutor brasileiro de W ou le souvenir d'enfance tenha preferido a palavra 'memória' [mémoire] à 'lembrança' [souvenir], eu prefiro manter a palavra 'lembrança' por sua recorrência e reverberação na obra perequiana (como se verá mais adiante). Cf. PEREC. W ou a memória da infância, 1995.

${ }^{180}$ [...] je suis allé avec ma tante voir une exposition sur les camps de concentration. Elle se tenait du côté de La Motte-Picquet-Grenelle (ce même jour, j'ai découvert qu'il existait des métros qui n'étaient pas souterrains mais aériens). Je me souviens des photos montrant les murs des fours lacérés par les ongles des gazés et d'un jeu d'échecs fabriqués avec des boulettes de pain.

${ }^{181}$ [...] dans l'accumulation l'objet disparaît comme individu au profit de son émergence comme espèce, de sa réapparition sous la forme universelle d'objet générique. Transformant le particulier en général, l'accumulation est donc une opération d'abstraction. FRANCBLIN. Les Nouveaux Réalistes, 1997, p. 48.
} 
aberturas nas obras desses artistas que permitiriam que, mantidas as condições que caracterizam uma acumulação, alguns exemplares fossem trocados ou então que se acrescentassem ali novos exemplares, sem que isso afetasse o sentido geral da obra. Se em Les choses de Perec, é possível reconhecer vários tipos de acumulações, o exercício de acumulação de Arman, mesmo que aqui se apresente concentrado em um único trabalho, não se resume unicamente a ele, devendo ser pensado, como indica Eschapasse (Cf. item 1.3.), como uma 'peça' parte de uma 'série'.

Em termos gerais, o exercício de acumulação é um gesto compulsivo que visa a desestabilizar o quantificável para deixar eclodir o inumerável, o muito, o que é impossível ou difícil de numerar - uma forma de designar o infinito. E por que isso? Porque qualquer série que é, ou que pareça ser quantificável expõe um limite, uma completude, um esgotamento, uma finalização, o que nunca interessou a esses artistas das acumulações e que, de certa maneira, Perec confirma aqui ao tratar de seu primeiro livro: "Les choses é um romance que quer dizer muitas coisas, essas coisas serão diferentes seguindo isso que traz consigo o leitor, quer dizer, o livro não tem significação por si." 182

Se junto às obras de Arman acumulamos nossas angústias, talvez, nossos fracassos, nossos desastres, com Les choses acumulamos nossos desejos, nossas fantasias, nossos mitos.

As portas abertas deixadas por Perec em Les choses serviriam tanto para o leitor pensar a sua posição com relação àquilo que lhe era apresentado, como também permitiriam ao escritor continuar transitando pelo campo incerto das coisas, onde o exercício acumulativo se mostraria uma prática de possibilidades infinitas. Um aspecto evidente disso está na lista de obras que ele esperava ainda escrever e que termina em reticências:

[...] minha ambição de escritor seria de percorrer toda a literatura de meu tempo sem nunca ter o sentimento de voltar sobre meus passos ou de voltar a andar sobre meus próprios traços, de escrever tudo o que é possível a um homem de hoje escrever: livros grandes e livros curtos, romances e poemas, dramas, libretos de ópera, romances policiais, romances de aventura, romances de ficção científica, folhetins, livros para crianças... ${ }^{183}$

${ }^{182}$ Les Choses est un roman qui veut dire plusieurs choses, ces choses seront différentes suivant ce qu'apporte le lecteur, c'est-à-dire [que] le livre n'a pas de signification en soi. PRUNIER. Entretien Georges Perec / Patricia Prunier. (1967). In: PEREC. Entretiens et conférences, 2003a, p. 75.

${ }^{183}$ [...] mon ambition d'écrivain serait de parcourir toute la littérature de mon temps sans jamais avoir le sentiment de revenir sur mes pas ou de remarcher dans mes propres traces, et d'écrire tout ce qui est possible à un homme d'aujourd'hui d'écrire: des livres gros et des livres courts, des romans et des poèmes, des drames, des livrets d'opéra, des romans policiers, des romans d'aventures, des romans de sciencefiction, des feuilletons, des livres pour enfants... PEREC. Notes sur ce que je cherche. (1978). In:

Penser / Classer, 2003c, p. 11. 


\section{A coleção, ou, o que ainda falta}

\subsection{As coisas comuns}

[Lembrança $\left.\mathrm{n}^{\circ}\right] 9$

Eu me lembro de Ploum ploum tra la la. ${ }^{184}$ (Jms, p. 15)

Um ‘eu me lembro’ não é interessante sozinho. Acumulados, o fato de haver
quatrocentos $($ sic $){ }^{185}$ dá, restitui uma época a partir desses pequenos buracos, desses
pequenos esquecimentos recuperados.

Após a 'acumulação' em Les choses, agora é a vez de tratar da 'coleção' em Je me souviens. A partir desse momento, as obras de Perec a serem apresentadas dispensam fábulas e personagens, o que é dado é o resto: fragmentos e desimportâncias apreendidos no real. A obra toca o desinteressante e, exatamente por isso, é tão importante.

Tudo começa com um vasto programa de escrita autobiográfica que deveria ocupar o escritor por doze anos, mas que foi abandonado após seis. Esse projeto se chamava Lieux e será tratado no capítulo seguinte. Esta pesquisa não segue uma apresentação cronológica da obra de Perec e damos um salto até 1978 quando ele publica Je me souviens, o primeiro volume de um conjunto de quatro obras, que deveria tratar das 'coisas comuns' - tema central deste capítulo.

Não vamos direto à obra, é necessário dar uma volta e passar por outras complexidades até chegar a ela e assim entender o quanto a sua simplicidade é apenas aparente. Deveremos primeiro dar uma passada rápida sobre o que compunha esse vasto programa autobiográfico para entender a opção do escritor pelo campo do cotidiano e do coletivo. Então, apresento a tradução completa do editorial que Perec escreveu para a revista Cause commune - um manifesto a favor das coisas comuns, do endótico -, importante para o entendimento da concepção de infraordinário que domina parte significativa da obra de Perec. Depois, trato de um sistema de regras - as contraintes [restrições] - adotado originalmente

\footnotetext{
${ }^{184}$ [Souvenir $\mathrm{n}^{\circ}$ ] 9 / Je me souviens de Ploum ploum tra la la.

${ }^{185}$ Os 'eu me lembro' contidos em Je me souviens não se limitam a quatrocentos, mas a quatrocentos e oitenta.

${ }^{186}$ Un “je me souviens” n'est pas intéressant en soi. Accumulés, le fait qu'il y en ait quatre cents (sic) donne, restitue une époque à partir de ces petits trous, de ces petits oublis retrouvés. PEREC. En dialogue avec l'époque. (1979). In: Entretiens et Conférences, 2003b, p. 62.
} 
para a elaboração textual e que Perec aprendeu e desenvolveu no OuLiPo, mas que ele levaria consigo - tal como uma variação do procedimento de distanciamento de Brecht - para direcionar suas ações no real e assim ter acesso ao que se esconde sobre o véu do banal e do habitual.

Ao mesmo tempo em que Perec se preocupava com as 'coisas comuns' e o cotidiano, nos Estados Unidos, a Arte Pop, através da colagem e do exercício da citação, também se interessava pelo cotidiano urbano, pelo banal, fazendo uso da repetição e da coleta do que podia ser apreendido diretamente no real e trazido para o espaço da obra. Para entender como esses 'coletores de objetos' sistematizavam o que encontravam e/ou produziam, vou tratar do que é característico no formato da coleção - maneira organizada de agrupar objetos tendo como polo centralizador a figura do colecionador. Só aí chegaremos às obras de Joe Brainard e Georges Perec: as duas com o mesmo título e o mesmo estatuto de coleção, mas se a primeira explora afetos e acontecimentos marcantes a partir do pessoal, a segunda se fixa no banal e no desimportante do coletivo.

\subsubsection{Os projetos de escrita}

Perec, ao longo de sua carreira, escrevia frequentemente sobre seus projetos literários. Essa era sua maneira de repensar antigos esforços, orientar e questionar ideias, antecipar iniciativas e comunicar aos outros o que fazia, bem como receber orientações e/ou comentários. No início, isso se dava por meio de bilhetes que podiam ajudá-lo a orientar seu trabalho de escrita em meio a suas atividades normais do dia a dia, quando ele dividia seus esforços entre a literatura e o trabalho como arquivista do $\mathrm{CNRS}^{187}$. Depois, conforme sua produção se avolumava e se tornava mais complexa, ele começou a escrever 'projetos de escrita' nos quais ele estabelecia, entre outras coisas, os vários elementos, procedimentos, temas, interesses que ele deveria abordar na construção de uma única obra ou num grupo delas $^{188}$.

\footnotetext{
${ }^{187}$ Perec trabalhou como documentaliste [arquivista] no Laboratório Associado 38 do CNRS (Centre national de la recherche scientifique), unidade especializada em neurofisiologia, por dezessete anos (1961 a 1978). Ele só deixou esse emprego após ter publicado La Vie mode d'emploi, quando pôde, enfim, se dedicar integralmente à literatura.

${ }^{188}$ Philippe Lejeune reconhece que no campo da produção perequiana, o 'projeto' ou 'programa' de escrita poderiam ser considerados um micro gênero literário, já que muitas vezes deixavam o universo dos escritos
} 
Perec desenvolveu simultaneamente vários projetos de escrita que, quando não resultavam em publicações, serviam de subsídio ou se desmembravam em novos projetos de escrita. É por isso que, para tratar do projeto que ele denominou Les choses communes [As coisas comuns], é necessário entender um projeto mais abrangente no qual ele pretendeu compor um vasto grupo autobiográfico, mas que ele encontraria dificuldades para levar adiante. Perec acabaria recompondo suas prioridades e levaria adiante uma literatura que, mesmo fundada em experiências pessoais, acabaria por tratar do que é comum a um grupo, a uma comunidade, a uma cidade, a uma geração, dando continuidade ao que ele havia começado em Les choses.

Em 1969, Perec escreve uma carta a Maurice Nadeau, seu editor, para especificar os trabalhos em curso e suas ideias para projetos futuros ${ }^{189}$. Ele tratava então de um amplo conjunto autobiográfico composto por quatro livros: L'Arbre - Histoire d'Esther et de sa famille [A Árvore - História de Esther e de sua família] ${ }^{190}$; Lieux [Lugares] ${ }^{191}$; Lieux où j’ai dormi [Lugares onde dormi] ${ }^{192}$; e $W^{193}$. O prazo para a escrita dessas quatro obras era dado pelo prazo necessário para escrever Lieux - projeto ambicioso de escrita que demandaria do autor visitas mensais ao longo de doze anos a cada um de doze lugares escolhidos na cidade de Paris e que ele pretendia acompanhar o 'envelhecimento'.

Claude Burgelin e Philippe Lejeune concordam com a centralidade do que se pode chamar de 'conflito autobiográfico' presente na obra de Perec. Sem poder afirmar que a

particulares do autor (manuscritos e cartas) para virarem artigos avulsos ou para serem incorporados em obras maiores. Cf. LEJEUNE. La mémoire et l'oblique, 1991, p. 16.

Esse tipo de iniciativa de Perec guardaria muitas semelhanças com o que vinham fazendo na mesma época os artistas conceituais que, algumas vezes, por meio da simples enunciação de uma intervenção no real, já davam por concluído o gesto criativo. O livro de Édouard Levé EEuvres - uma grande lista de projetos de obras que o artista pensou e não realizou -, e uma aproximação da Arte Conceitual são assuntos do próximo capítulo.

${ }^{189}$ PEREC. Lettre à Maurice Nadeau. (1969). In: .Je suis né, 2006, pp. 51- 66.

${ }^{190}$ Perec pretendia, a partir de uma estrutura em árvore, descrever em minúcias as várias conexões e histórias das três famílias que compunham seu grupo familiar: a família de seu pai, a de sua mãe e a de sua tia (irmã do seu pai, encarregada de cuidar de Perec após o falecimento dos pais).

191 Tratarei desse projeto em mais detalhes no próximo capítulo.

${ }^{192}$ Perec pensava compor com essa obra algo como uma 'autobiografia vesperal' através da descrição minuciosa dos quartos onde havia dormido.

${ }^{193}$ Nesse momento, Perec pensava fazer desse livro um romance de aventuras. Ele seria escrito a partir de uma lembrança da infância no momento em que ele fazia sua primeira psicoterapia: tratava-se de uma história que ele havia inventado quando tinha doze ou treze anos sobre uma ilha chamada 'W', situada em algum lugar da Terra do Fogo e onde vivia uma civilização de atletas que usava em suas roupas a marca do nome da ilha. 
autobiografia esteja evidente o tempo todo e em toda parte, Burgelin ${ }^{194}$ prefere dizer que ela se insinua o tempo todo, sempre deslocada, esquiva e disfarçada, tal como um personagem que é descrito e sobre o qual todos falam, ainda que nunca se apresente por inteiro, de verdade, com um mínimo de autonomia. A escrita autobiográfica de Perec acabou se dando por desvios, maneira encontrada pelo autor para evitar um choque frontal com o drama de uma infância traumática. A autobiografia para esse autor não era um fim, mas um dos seus campos de pesquisa e cultivo. No estudo sobre o exercício autobiográfico na obra de Perec, Philippe Lejeune escreve: “[...] a escrita autobiográfica não foi para Perec nem uma atividade constante [...] nem uma atividade 'terminal' [...], mas que ela corresponde a uma fase mediana, a uma crise, a uma metamorfose, depois da qual ela se apagou, se voltou ao segundo plano." 195

\title{
2.1.2. Um novo rumo para as coisas
}

\begin{abstract}
Tanto as coisas quanto as palavras foram para ele sinais de questionamento, pontos de amarra que não fizeram falta. As palavras o salvaram. Mas sem dúvida, as coisas também. Toda a sua obra testemunha sua gratidão a respeito desses sinais materiais - objetos, imagens, quadros, etc. - que, geralmente, duram mais que os humanos e carregam um testemunho sobre eles, sobre suas vidas e seus desejos. A atenção generosa com relação às palavras implica a mesma atenção generosa com relação às coisas. ${ }^{196}$

Claude Burgelin
\end{abstract}

Em 1973 ocorre uma reorientação do trabalho de Perec no que se refere ao conjunto autobiográfico citado na carta a Nadeau: agora, ao invés de destacar os aspectos relacionados ao passado, ao tempo e à sua interioridade, ele passava a explorar aspectos voltados ao presente, ao espaço e ao cotidiano urbano (ainda que a autobiografia continuasse a reverberar em todos esses campos). O projeto de Lieux, por exemplo, que seria abandonado

${ }^{194}$ BURGELIN. Georges Perec, 2002, p. 19.

195 [...] l'écriture autobiographique n'a pas été pour Perec ni une activité constante [...] ni une activité "terminale" [...], mais qu'elle correspond à une phase médiane, à une crise, à une métamorphose, après laquelle elle s'est effacée, est revenue au second plan. LEJEUNE. La mémoire et l'oblique, 1991, p. 16.

${ }^{196}$ Les choses autant que les mots ont été pour lui des signes à interroger, des points d'attache qui n'ont pas fait défaut. Les mots l'ont sauvé. Mais sans doute aussi les choses. Toute son æeuvre témoigne de sa gratitude à l'égard de ces signes matériels - objets, images, tableaux, etc. - qui, souvent, durent davantage que les humains et portent témoignage sur eux, sur leurs vies et leurs désirs. L'attention bienveillante aux mots implique la même attention bienveillante aux choses. BURGELIN. Op. cit., pp. 11-12. 
definitivamente em 1975 e que tinha uma estrutura dividida entre descrições e lembranças, impulsionaria Perec a escrever, além de vários textos curtos, os livros: Espèces d'espace [Espécies de espaço] (1974), Tentative d'épuisement d'un lieu parisien [Tentativa de esgotamento de um lugar parisiense] (1975) e Je me souviens [Eu me lembro] (1978); já, quanto aos outros projetos autobiográficos, eles serviriam para que Perec retomasse $W-$ obra que ele havia publicado em capítulos como uma novela de aventuras em La quinzaine littéraire (1969-1970) - para reescrevê-la na forma de duas narrativas paralelas e intercaladas: uma ficcional, que mantinha mais ou menos o mesmo conteúdo da primeira versão, e outra autobiográfica, que tratava da infância do autor até completar dez anos de idade, com o título ampliado para Wou le souvenir d'enfance [W ou a lembrança da infância] (1975).

Agora, ao invés de se voltar para os momentos de exceção - que são o interesse maior da História com agá maiúsculo, Perec se voltava para a história com agá minúsculo, aquela que anda de mãos dadas com o habitual e as coisas comuns ${ }^{197}$.

O título do projeto de escrita Choses communes nos propõe uma ligação entre o primeiro livro de Perec - Les choses - com a revista Cause commune [Causa comum], revista que duraria de 1972 a 1974 e que ele seria convidado a criar junto com Paul Virilio - vindo da École Spéciale d'Architecture -, e Jean Duvignaud - antigo professor de filosofia de Perec, seu primeiro mentor. Nessa revista, eles pretendiam tratar do que chamavam de uma 'sociologia da vida cotidiana', como é detalhado no editorial do primeiro número:

\footnotetext{
Cause commune não é uma revista: é uma tribuna aberta a todos aqueles que queiram participar no seu esforço, um lugar de pesquisas e discussões onde não se imporá nenhuma ideologia particular, nenhuma doutrina a procura de um absoluto improvável...

Essa publicação se propõe vários objetivos:

Criar raízes e recolocar em questão as ideias e as crenças sobre as quais repousa o funcionamento de nossa civilização, de nossa cultura, empreender visto que se pode fazer uma antropologia do homem contemporâneo,

[...]

empreender uma investigação da vida cotidiana em todos os seus níveis, nas suas dobras ou nas suas cavernas geralmente desdenhadas ou recalcadas, analisar os objetos oferecidos à satisfação dos nossos desejos - obras de arte, obras de cultura, produtos de consumo - na relação deles com nossa vida e as realidades de nossa experiência comum $\left[\ldots . . .{ }^{198}\right.$
}

197 “A História com seu grande agá”, afirma Perec em W ou le souvenir d'enfance, seria a responsável por ele não ter lembranças da infância e, assim, não ser capaz de escrever sua própria história - essa, com agá minúsculo. Às perguntas que o menino judeu fazia sobre sua infância, a única resposta que ele podia receber da História dizia respeito à guerra e aos campos de concentração. Cf. PEREC. W ou le souvenir d'enfance, 2003d, p. 17.

${ }^{198}$ Cause commune n'est pas une revue: c'est une tribune ouverte à tous ceux qui veulent participer à son effort, un lieu de recherches et de discussions où ne s'imposera aucune idéologie particulière, aucune doctrine en quête d'un introuvable absolu. . . I Cette publication se propose plusieurs buts: / Prendre à leur racine et 
Vem daí o sentido ambíguo que Perec dava à palavra 'commune’ [comum], que tanto significa o desimportante como o que está disponível a todos e, portanto, pode ser compartilhado. Na obra de Perec, as coisas comuns representam tanto um campo de reflexões sobre o cotidiano como um projeto de escrita do qual fariam parte várias de suas obras.

Suas ideias sobre essas coisas comuns estão expostas em Approches de quoi? [Aproximações de quê?] ${ }^{199}$, editorial com ares de manifesto que ele escreveu para a revista Cause commune a favor de um interesse mais cuidadoso no sentido de reconhecer o que seria o ruído de fundo, que é o mesmo que o infraordinário, e que Perec define como "isso que acontece quando não acontece nada" 200 - a própria noção de cotidiano.

Mas “o cotidiano escapa”, Maurice Blanchot repete várias vezes ao longo de A fala cotidiana $^{201}$ para reforçar o quanto é difícil tentar se aproximar dele e tomá-lo de alguma forma. É que, para Blanchot, o cotidiano pertence à insignificância do que sempre esteve ali e não permite um primeiro encontro ou uma descoberta, uma estreia. "O cotidiano escapa" também porque não tem sujeito, não expõe nomes e se ali alguns falam e outros ouvem, não é possível saber quem faz o quê, só se sabe que ali se fala alguma coisa: o ruído de fundo.

O cotidiano é o próprio território da ambiguidade, da incerteza, dos desvios e dos emaranhados. "No cotidiano", escreve Blanchot ${ }^{202}$, "não temos mais nome, temos pouca realidade pessoal e quase não temos uma figura, [...] o cotidiano dissolve as estruturas e desfaz as formas [...]." Não podendo ser assumido por um sujeito verdadeiro, já que o cotidiano é o nível da vida sem lugar para o que é único, distintivo, objetivo, com começo e fim - "o cotidiano", avisa Blanchot ${ }^{203}$, "tende sem cessar a entorpecer-se em coisas".

Está aí a maior dificuldade em querer enfrentar o corriqueiro sem fazer disso um ato extraordinário, que anularia por completo o valor inicial do que se procura: revelar o banal, o

remettre en question les idées et les croyances sur lesquelles repose le fonctionnement de notre civilisation, de notre culture, entreprendre autant que faire se peut une anthropologie de l'homme contemporain, / [...] / entreprendre une investigation de la vie quotidienne à tous ses niveaux, dans ses replis ou ses cavernes généralement dédaignés ou refoulés, / analyser les objets offerts à la satisfaction de nos désirs - auvres d'art, auvres de culture, produits de consommation - dans leur rapport avec notre vie et les réalités de notre expérience commune [...]. PEREC. Complément I - Cause commune: éditorial du premier numéro. (1972). In: Entretiens et Conférences, 2003a, p. 133.

${ }^{199}$ Cf. item 2.1.2.1.

${ }^{200}[\ldots]$ ce qui se passe quand il ne se passe rien [...]. PEREC. Ce qu'il se passe quand il ne se passe rien. (1978). In: Entretiens et Conférences, 2003a, p. 214.

${ }^{201}$ BLANCHOT. A fala cotidiana. In: A conversa infinita, 2007, p. 237.

${ }^{202}$ Ibidem, p. 241.

${ }^{203}$ Ibidem, p. 244. 
sempre assim. A tarefa proposta por Perec é se afastar do exótico e fundar uma nova antropologia, uma ciência preocupada com o que ele chamou de 'o endótico'.

Também no campo dos questionamentos do infraordinário, Perec publicaria no ano seguinte (1974) uma obra que ampliaria bastante o espectro das suas preocupações sobre o infraordinário: é Espèces d'espaces. Ali, Perec teve a oportunidade de ampliar seus questionamentos sobre as coisas comuns - a matéria, os objetos, as ferramentas, os hábitos -, e poder pensar num tipo de territorialidade que acolhe as coisas e que define lugares, edifícios, cidades, etc. Sobre seu propósito, Perec escreveu na orelha do livro: "o problema não é de inventar o espaço, menos ainda de reinventá-lo [...] mas de interrogá-lo, ou, mais simplesmente ainda, de lê-lo; já que isso que chamamos de cotidianidade não é evidência, mas opacidade: uma forma de cegueira, uma maneira de anestesia" ${ }^{204}$ (Ee).

\subsubsection{Tradução: Aproximações de quê?}

Editorial da $5^{\mathrm{a}}$ edição da revista Cause commune $(1973) .{ }^{205}$

O que nos informa, me parece, é sempre o acontecimento, o insólito, o extraordinário: cinco colunas por uma, grandes manchetes. Os trens não começam a existir a não ser quando descarrilam, e quanto mais passageiros mortos há, mais os trens existem; os aviões não alcançam a existência senão quando são desviados; os carros têm por único destino se chocarem contra os plátanos: cinquenta e dois fins de semana por ano, cinquenta e dois balanços: tanto mais mortos e tanto melhor para a informação se os números não deixam de aumentar! É necessário que haja por detrás do acontecimento um escândalo, uma ferida, um perigo, como se a vida só se revelasse através do espetacular, como se o ser falante, o significativo fosse sempre anormal: cataclismos naturais ou perturbações históricas, conflitos sociais, escândalos políticos...

$\mathrm{Na}$ nossa precipitação para medir o histórico, o significativo, o revelador, não deixemos de lado o essencial: o verdadeiramente intolerável, o verdadeiramente inadmissível: o escândalo não é o grisu, é o trabalho nas minas. As "doenças sociais" não são "preocupantes" em período de greve, elas são intoleráveis vinte e quatro horas sobre vinte e quatro, trezentos e sessenta e cinco dias por ano.

Os maremotos, as erupções vulcânicas, as torres que desmoronam, os incêndios de florestas, os túneis que desabam, Publicis que queima e Aranda que fala! Horrível! Terrível! Monstruoso! Escandaloso! Mas onde está o escândalo? O verdadeiro

${ }^{204}$ Le problème n'est pas d'inventer l'espace, encore moins de le ré-inventer [...] mais de l'interroger, ou, plus simplement encore, de le lire; car ce que nous appelons quotidienneté n'est pas évidence, mais opacité: une forme de cécité, une manière d'anesthésie.

205 PEREC. Approches de quoi? (1973). In: L'infra-ordinaire, 1989, pp. 9-13. 
escândalo? O jornal nos disse outra coisa: fique tranquilo, você bem sabe que a vida existe, com seus altos e baixos, você bem sabe que as coisas acontecem.

Os jornais falam de tudo menos do cotidiano. Os jornais me chateiam, não me ensinam nada; o que eles contam não me diz respeito, não me questiona e não responde mais às perguntas que eu faço ou que eu gostaria de fazer.

Isso que acontece de verdade, isso que vivemos, o resto, todo o resto, onde ele está? Isso que acontece cada dia e que volta a acontecer a cada dia, o banal, o cotidiano, o evidente, o comum, o ordinário, o infraordinário, o ruído de fundo, o habitual, como nos darmos conta dele, como interrogá-lo, como descrevê-lo?

Interrogar o habitual. Mas justamente, nós estamos habituados a ele. Nós não o interrogamos, ele não nos interroga, parece que não constitui problema, nós o vivemos sem pensar nele, como se ele não veiculasse nem perguntas nem respostas, como se ele não carregasse qualquer informação. Nem é mais o condicionamento, é a anestesia. Nós dormimos nossa vida de um sono sem sonhos. Mas onde ela está, nossa vida? Onde está nosso corpo? Onde está nosso espaço?

Como falar dessas "coisas comuns", como persegui-las mais precisamente, como desemboscá-las, arrancá-las do invólucro onde estão coladas, como dar a elas um sentido, uma língua: que elas falem enfim do que é, do que somos.

Talvez se trate de fundar enfim nossa própria antropologia: aquela que falará de nós, que irá procurar em nós isso que nós por muito tempo pilhamos dos outros. Não mais o exótico, mas o endótico.

Interrogar isso que parece de tal maneira sair de nós que até nos esquecemos da sua origem. Reencontrar alguma coisa de surpreendente que poderia marcar Jules Verne ou seus leitores em face de um aparelho capaz de reproduzir e de transportar os sons. Pois ele existiu, esse assombro, e milhares de outros, e foram eles que nos modelaram.

Isso que se trata de interrogar, é o tijolo, o concreto, o vidro, nossas maneiras à mesa, nossos utensílios, nossas horários, nossos ritmos. Interrogar isso que parece ter acabado para sempre de nos surpreender. Vivemos, é verdade, respiramos, é verdade; andamos, abrimos as portas, descemos as escadas, nos sentamos a uma mesa para comer, deitamos em uma cama para dormir. Como? Onde? Quando? Por quê?

\section{Descreva sua rua. Descreva outra. Compare.}

Faça o inventário dos seus bolsos, da sua sacola. Se interrogue a respeito da procedência, o uso e o futuro de cada um dos objetos que você retirar dali.

Questione suas colherinhas.

O que há sob o seu papel de parede?

Quantos gestos são necessários para discar um número de telefone? Por quê?

Porque não encontramos cigarros nas mercearias? Porque não?

Pouco me importa que essas questões sejam, aqui, fragmentárias, apenas indicativas de um método, quanto muito de um projeto. É muito importante para mim que elas pareçam triviais e fúteis: é precisamente isso que faz delas, senão mais, 
essenciais que tantas outras através das quais nós realmente tentamos captar nossa verdade. $^{206}$

${ }^{206}$ Approches de quoi?

Ce qui nous parle, me semble-t-il, c'est toujours l'événement, l'insolite, l'extra-ordinaire: cinq colonnes à la une, grosses manchettes. Les trains ne se mettent à exister que lorsqu'ils déraillent, et plus il y a de voyageurs morts, plus les trains existent; les avions n'accèdent à l'existence que lorsqu'ils sont détournés; les voitures ont pour unique destin de percuter les platanes: cinquante-deux weekends par an, cinquantedeux bilans: tant de morts et tant mieux pour l'information si les chiffres ne cessent d'augmenter! Il faut qu'il y ait derrière l'événement un scandale, une fissure, un danger, comme si la vie ne devait se révéler qu'à travers le spectaculaire, comme si le parlant, le significatif était toujours anormal: cataclysmes naturels ou bouleversements historiques, conflits sociaux, scandales politiques... / Dans notre précipitation à mesurer l'historique, le significatif, le révélateur, ne laissons pas de côté l'essentiel: le véritablement intolérable, le vraiment inadmissible: le scandale, ce n'est pas le grisou, c'est le travail dans les mines. Les "malaises sociaux" ne sont pas "préoccupants" en période de grève, ils sont intolérables vingt-quatre heures sur vingt-quatre, trois cent soixante-cinq jours par an. / Les raz-de-marée, les éruptions volcaniques, les tours qui s'écroulent, les incendies de forêts, les tunnels qui s'effondrent, Publicis qui brûle et Aranda qui parle! Horrible! Terrible! Monstrueux! Scandaleux! Mais où est le scandale? Le vrai scandale? Le journal nous a-t-il dit autre chose que: soyez rassurés, vous voyez bien que la vie existe, avec ses hauts et ses bas, vous voyez bien qu'il se passe des choses. / Les journaux parlent de tout, sauf du journalier. Les journaux m'ennuient, ils ne m'apprennent rien; ce qu'ils racontent ne me concerne pas, ne m'interroge pas et ne répond pas davantage aux questions que je pose ou que je voudrais poser. / Ce qui se passe vraiment, ce que nous vivons, le reste, tout le reste, où est-il? Ce qui se passe chaque jour et qui revient chaque jour, le banal, le quotidien, l'évident, le commun, l'ordinaire, l'infra-ordinaire, le bruit de fond, l'habituel, comment en rendre compte, comment l'interroger, comment le décrire? / Interroger l'habituel. Mais justement, nous y sommes habitués. Nous ne l'interrogeons pas, il ne nous interroge pas, il semble ne pas faire problème, nous le vivons sans y penser comme s'il ne véhiculait ni question ni réponse, comme s'il n'était porteur d'aucune information. Ce n'est même plus du conditionnement, c'est de l'anesthésie. Nous dormons notre vie d'un sommeil sans rêves. Mais où est-elle, notre vie? Où est notre corps? Où est notre espace? / Comment parler de ces "choses communes", comment les traquer plutôt, comment les débusquer, les arracher à la gangue dans laquelle elles restent engluées, comment leur donner un sens, une langue: qu'elles parlent enfin de ce qui est, de ce que nous sommes. / Peut-être s'agit-il de fonder enfin notre propre anthropologie: celle qui parlera de nous, qui ira chercher en nous ce que nous avons si longtemps pillé chez les autres. Non plus l'exotique, mais l'endotique. I Interroger ce qui semble tellement aller de soi que nous en avons oublié l'origine. Retrouver quelque chose de l'étonnement que pouvaient éprouver Jules Verne ou ses lecteurs en face d'un appareil capable de reproduire et de transporter les sons. Car il a existé, cet étonnement, et des milliers d'autres, et ce sont eux qui nous ont modelés. / Ce qu'il s'agit d'interroger, c'est la brique, le béton, le verre, nos manières de table, nos ustensiles, nos outils, nos emplois du temps, nos rythmes. Interroger ce qui semble avoir cessé à jamais de nous étonner. Nous vivons, certes, nous respirons, certes; nous marchons, nous ouvrons des portes, nous descendons des escaliers, nous nous asseyons à une table pour manger, nous nous couchons dans un lit pour dormir. Comment? Où? Quand? Pourquoi? / Décrivez votre rue. Décrivez-en une autre. Comparez. / Faites l'inventaire de vos poches, de votre sac. Interrogez-vous sur la provenance l'usage et le devenir de chacun des objets qu; vous en retirez. I Questionnez vos petites cuillers. / Qu'y a-t-il sous votre papier peint? / Combien de gestes faut-il pour composer un numéro de téléphone? Pourquoi? / Pourquoi ne trouve-t-on pas de cigarettes dans les épiceries? Pourquoi pas? IIl m'importe peu que ces questions soient, ici, fragmentaires, à peine indicatives d'une méthode, tout au plus d'un projet. Il m'importe beaucoup qu'elles semblent triviales et futiles: c'est précisément ce qui les rend tout aussi, sinon plus, essentielles que tant d'autres au travers desquelles nous avons vainement tenté de capter notre vérité. 


\subsection{Perec e sua máquina de texto}

Eu quero dizer que as contraintes funcionam como... Para mim, no interior do sistema de escrita, as contraintes são um pouco como a dinamite que eu coloco sob o sistema para fazê-lo explodir. As contraintes de base de 'A Vida manual de instruções, ${ }^{207}$ é uma máquina de fabricar ficção. ${ }^{208}$

$[\ldots]$ eu me dou regras para ser totalmente livre. ${ }^{209}$

Georges Perec

Para que Perec pudesse se desviar disso que na aproximação do cotidiano é puro impedimento - e que repete a litania de Blanchot: "o cotidiano escapa"! -, ele precisaria quebrar os paradigmas que dão o cotidiano como pura evidência e ainda achar uma maneira de dar a esse exercício uma língua e um sentido. Perec recorreu então a um procedimento de distanciamento que, à maneira de Brecht, lhe permitiu: 1) se descondicionar; 2) se surpreender; e ainda 3) compartilhar - condição indispensável para o reconhecimento do que é 'comum'. O procedimento se chama contrainte [restrição] ${ }^{210}$, e sua escola foi o OuLiPo.

Se no início os sinais materiais presentes em Les choses indicavam ao leitor aquilo que era puro desejo no mundo da sociedade do consumo, muito rapidamente Perec passou a identificar o próprio ofício de escrever como um exercício de sedução entre o escritor e o leitor no qual a palavra seria a matéria, o texto seria o objeto e a motivação seria sua necessidade de tentar recompor e contar sua história. "O projeto de escrever minha história se formou quase ao mesmo tempo em que meu projeto de escrever" ${ }^{211}$, é o que afirma Perec em $W$ (p. 45), sua autobiografia fraturada: duas narrativas paralelas que não se encontram nunca, reverberando o trauma da perda dos pais na infância.

\footnotetext{
${ }^{207}$ Embora o título da edição brasileira seja 'A Vida modo de usar', eu prefiro traduzi-lo como 'A Vida manual de instruções'. Ainda que as expressões sejam sinônimas, eu entendo que a expressão 'manual de instruções' resulte em algo mais próximo do que Perec entendia compor os mecanismos artificiais que ele havia criado para a elaboração de seu livro, ou seja, uma máquina de escrever histórias.

${ }^{208}$ Je veux dire que les contraintes fonctionnent comme... Pour moi, à l'intérieur du système d'écriture, les contraintes sont un peu comme de la dynamite que je mets en dessous du système pour le faire exploser. Les contraintes de base de La Vie mode d'emploi, c'est une machine à fabriquer de la fiction. PEREC. Création et contraintes dans la production littéraire. (1981). In: Entretiens et Conférences, 2003b, p. 321.

${ }^{209}$ [...] je me donne des règles pour être totalement libre. PEREC. Georges Perec: "des règles pour être libre”. (1977). In:__. Entretiens et Conférences, 2003a, p. 208.

${ }^{210}$ Para esta pesquisa eu optei por adotar o termo original em francês, sem traduzi-lo, visto que esse é um termo consagrado na literatura francesa, indicador de regras, procedimentos e estruturas formais na composição de textos literários.

${ }^{211}$ Le projet d'écrire mon histoire s'est formé presque en même temps que mon projet d'écrire.
} 
Foi para continuar seduzindo seu leitor que Perec buscou renovar/atualizar sua escrita, se aliando ao que Jacques Roubaud chamou de "o demônio da forma, um demônio criador e disciplinado" 212 e assim poder se livrar de outro demônio: "o demônio mau, o demônio vadio por excelência que assombra o romancista contemporâneo: o hábito" ${ }^{213}$.

A vida material, a autobiografia, a sedução do leitor e o jogo da forma - tudo ao mesmo tempo - parecem campos muito distantes para fazer parte de um único projeto de escrita de um único escritor, mas é esse o caso de Perec, que levou adiante essa proposta a partir do momento que foi aceito como membro do OuLiPo em 1967.

O OuLiPo - Ouvroir de littérature potentielle [Oficina de literatura potencial] - é um grupo que foi criado em 1960 por Raymond Queneau e François Le Lionnais com o intuito de explorar, recompor, desenvolver e propor um arsenal de formas e estruturas novas que permitissem aos escritores escrever suas obras sem estar na dependência da volubilidade das forças naturais da genialidade e/ou de algum tipo de inspiração na indicação do caminho a seguir. Inicialmente o grupo era formado por escritores e matemáticos que buscavam meios de estabelecer uma aproximação entre esses dois campos do saber bradando sempre uma frase de Claude Berge, lembrada por Marcel Bénabou: “o Oulipo é o anti-acaso” 214.

No centro dos trabalhos oulipianos está a contrainte, que pode ser entendida como uma série de regras e/ou procedimentos de escrita. Isso que o termo 'contrainte' indica no campo literário já era empregado há séculos antes do OuLiPo visto que todo texto literário devia se adequar a uma série de regras relacionadas ao uso do vocabulário, da gramática, do gênero, da forma da métrica, etc. O que muda com o OuLiPo é que, se antes o procedimento técnico/formal contribuía para reforçar algum aspecto ligado ao sentido do texto, a partir do OuLiPo, a contrainte também passou a ser usada como uma criadora de sentido.

Longe de representar um bloqueio ou um cerceamento da criatividade, os oulipianos encontravam nas limitações da contrainte um estímulo à imaginação, um exercício de descondicionamento através da suspensão das censuras do autor. Claude Burgelin, em

\footnotetext{
${ }^{212}[\ldots]$ le démon de la forme, un démon créateur et discipliné [...]. ROUBAUD. Le démon de la forme. In: Magazine littéraire, 1993, p. 65.

${ }^{213}[\ldots]$ le mauvais démon, le démon oisif par excellence qui hante le romancier contemporain, l'habitude. Ibidem.

${ }^{214}$ [...] "l'Oulipo, c'est l'anti-hasard". Claude Berge apud BÉNABOU. Quarante siècles d'Oulipo. In: Magazine littéraire, 2001, p. 21.

Para entender os propósitos e os trabalhos desenvolvidos pelo OuLiPo, cf. o artigo em português: PINO. $\underline{A}$ ressignificação do mundo. In: Cult, 2001, pp. 45-53.
} 
Estética e ética do Oulipo ${ }^{215}$, ressalta que o emprego da contrainte, mesmo não dando espaço ao acaso, resultava em algo que parecia chegar àquilo do que teria fugido: 'uma improvisação inesperada'. Além disso, longe de ser um exercício protocolar e impessoal, a simples escolha da contrainte pelo autor, já era por si só comprometedora e reveladora de sentidos e cabia, portanto, ao autor estabelecer essa pertinência. "A fixação sobre uma modalidade de obsessão é [já] uma assinatura" ${ }^{216}$, afirma Burgelin.

Era também comum aos trabalhos do OuLiPo tomar como ponto de partida, ou, como matéria a ser transformada/reciclada/atualizada, a obra de outros autores e para isso eles recorriam, entre outros procedimentos, ao plágio, à paródia e ao trabalho de continuação. Ao final dos seus exercícios, os oulipianos também citavam qual havia sido a matéria de base utilizada, permitindo, não só, que fossem comparados os resultados obtidos com o original, como também, questionando as noções de criação, apropriação, citação, releitura etc.

O próprio Perec expôs em vários momentos que seu interesse e sua relação com a palavra eram de ordem física e do trabalho prático:

A palavra que me parece a mais correta quando eu me esforço em me definir e definir o trabalho que faço não é nem romancista, nem mesmo escritor, mas homem de letras: um homem que tem as letras, o alfabeto, como seu objeto de trabalho: meu trabalho não se faz com ideias, sentimentos, imagens. ${ }^{217}$

Esse tipo de envolvimento fazia com que ele sentisse a necessidade de definir, desde o início do seu processo de criação, uma forma, um sistema, uma estrutura. Sobre a relação da invenção com a forma, Perec escreve:

\footnotetext{
A invenção para mim parte sempre de uma invenção formal.

No início, há uma necessidade traçada de escrever e essa necessidade de escrever encontra sua fonte em uma experiência pessoal ou em alguma coisa que me acontece e que em seguida é transformada por meio de uma invenção formal. ${ }^{218}$
}

\footnotetext{
${ }^{215}$ BURGELIN. Esthétique et éthique de l'Oulipo. In: Magazine littéraire, 2001, pp. 36- 39.

${ }^{216}$ La fixation sur une modalité d'obsession est une signature. Ibidem, p. 38.

${ }^{217}$ Le mot qui semble le plus juste lorsque je m'efforce de me définir et de définir le travail que je fais n'est ni romancier ni même écrivain, mais homme de lettres: un homme dont le travail a pour objet les lettres, l'alphabet: mon travail ne se fait pas avec des idées, des sentiments, des images. PEREC. Notes sur ce que je cherche. In: PEREC, Paulette (Éd.). Portrait(s) de Georges Perec, 2001, p. 113. (Versão diferente da publicada em Le Figaro (1978).e encontrada in: PEREC. Notes sur ce que je cherche. In: Penser / Classer, 2003c, pp. 9-12).

${ }^{218}$ L'invention part toujours pour moi d'une invention formelle.

Au départ, il y a un besoin tracé d'écrire et ce besoin d'écrire trouve sa source dans une expérience personnelle ou dans quelque chose qui m'arrive et qui ensuite est transformé au moyen d'une invention
} 
Mas isso não se dava sem conflitos e Perec reconhecia o pouco caso do sistema literário institucional para com as tentativas daqueles que se interessavam pelas questões formais da literatura:

Unicamente preocupada com suas grandes maiúsculas (a Obra, o Estilo, a Inspiração, a Visão do Mundo, as Opções fundamentais, o Gênio, a Criação etc.), a história literária parece ignorar deliberadamente a escrita como prática, como trabalho, como jogo. [...] As contraintes são aí tratadas como aberrações, monstruosidades patológicas da língua e da escrita; as obras que elas suscitam não têm direito ao estatuto de obra $[. ..]{ }^{219}$

Jean-Yves Pouilloux ${ }^{220}$ assinala que, no trabalho com a contrainte, existem dois tipos de trabalho: o primeiro é um trabalho fácil e se resume em obedecê-la e respeitá-la (o que já suscitaria muitas críticas pela vacuidade do procedimento); já, o outro tipo de trabalho é um trabalho difícil e para isso o autor deve se preparar para 'habitá-la, dar a ela um sentido e fazêla falar'. É isso que Perec buscou fazer ao tomar contraintes que servissem às suas necessidades e obsessões:

Essa palavra 'contrainte', já nos repreenderam várias vezes que isso introduzia alguma coisa que é muito pejorativo, do tipo... de uma obrigação, uma regra muito dura. De fato, essa contrainte, nós não a percebemos como uma provação, e de maneira alguma como uma restrição. [...] De fato, isso que procuramos, é algo que vai estimular nossa criatividade, é algo que vai funcionar um pouco como uma bomba, uma bomba aspiradora aonde, através do exercício da contrainte, chegaremos a produzir alguma coisa. ${ }^{221}$

Até ingressar no OuLiPo, o procedimento de escrita sobre o qual Perec falava com frequência era a colagem, que ele definia como "um esquema, uma promessa e uma condição

formelle. PAWLIKOWSKA. Entretien Georges Perec / Ewa Pawlikowska. (1981). In: PEREC. Entretiens et Conférences, 2003b, p. 201.

${ }^{219}$ Uniquement préoccupée de ses grandes majuscules (l'Euvre, le Style, l'Inspiration, la Vision du Monde, les Options fondamentales, le Génie, la Création, etc.), l'histoire littéraire semble délibérément ignorer l'écriture comme pratique, comme travail, comme jeu. [...] Les contraintes y sont traitées comme des aberrations, des monstruosités pathologiques du langage et de l'écriture; les æuvres qu'elles suscitent n'ont pas droit au statut d'œuvre [...]. PEREC. Histoire du lipogramme. In: OULIPO. La littérature potentielle, 2003a, p. 75.

${ }^{220}$ POUILLOUX. Histoires d'E. In: Magazine littéraire, 1983, pp. 24-25.

${ }^{221}$ Ce mot de contrainte, on nous a souvent reproché que ça introduisait quelque chose qui est assez péjoratif, du genre... une obligation, une règle très dure. En fait, cette contrainte, on ne la perçoit pas du tout comme une épreuve, et pas du tout comme une restriction. [...] En fait, ce qu'on cherche, c'est quelque chose qui va stimuler notre créativité, c'est quelque chose qui va fonctionner un peu comme une pompe, une pompe aspirante où, à travers l'exercice de la contrainte, on va arriver à produire quelque chose. PEREC. Création et contraintes dans la production littéraire. (1981). In: p. 309. Entretiens et Conférences, 2003b, 
da descoberta" 222 através da qual ele recopiava e/ou reescrevia frases inteiras de outros autores para incluí-las em suas narrativas ${ }^{223}$. Com isso, ele acreditava que sua obra, e de outros autores, estavam prestes a configurar 'un art citationnel' [uma arte citacional]. Perec acreditava que através desse procedimento, "animamos assim nosso museu pessoal, e reativamos nossas reservas literárias" ${ }^{224}$ e que seria possível, a partir do que outros antes dele haviam escrito, propor uma nova obra que se localizaria na continuidade da literatura do passado $^{225}$. Em outro momento, Perec amplia o âmbito das pesquisas que se faziam no campo da 'arte citacional' ao dar como exemplo o que também faziam os artistas da Arte Pop americana naquele momento (1967):

Logo, podemos chegar a uma espécie de literatura que podemos chamar de experimental, que podemos chamar de... citacional, por exemplo. [...] Enfim, o que há de interessante, são as relações dessa nova literatura com outras formas estéticas. Eu penso que esse tipo de literatura parece, enfim, tem, ou estabelece relações com a arte pop, com certa forma de arte pop, onde só se trata de pintar alguma coisa que já foi pintada $\left[\ldots . .{ }^{226}\right.$

Com o ingresso no OuLiPo, Perec não deixou de trabalhar com a colagem, mas passou a reconhecer a contrainte como um procedimento de escrita mais produtivo e instigante. Ao se referir à contrainte como 'máquina' e não como 'ferramenta', Perec designava aquele

${ }^{222}$ [Le collage, pour moi, c'est comme] un schème, une promesse et une condition de la découverte. PEREC. Le bonheur est un processus... on ne peut pas s'arrêter d'être heureux. (1965). In: Entretiens et Conférences, 2003a, p. 49.

${ }^{223}$ Perec falava abertamente que em Les choses (1965) ele havia incluído frases inteiras retiradas de Gustave Flaubert (L'Éducation sentimentale), Robert Antelme (L'Espèce humaine) e Paul Nizan (La Conspiration). Cf. Ibidem. Já para Un homme qui dort [Um homem que dorme] (1967) - terceiro livro seu publicado - ele havia recorrido a mais de uma dezena de autores, entre os quais: Kafka (Le Procès), Melville (Bartleby), Dante (L'Enfer), Joyce (Ulysse), e outros. Cf. BELLOS. Georges Perec, 1994, p. 382.

${ }^{224}$ On anime ainsi son musée personnel, on réactive ses réserves littéraires. PEREC. Op. cit., p. 49.

${ }^{225}$ Bertelli e Ribière, para esclarecer o que Perec chama de 'colagem', citam o que Aragon escreve de forma muito clara em Les Collages (pp. 123-124) - publicação contemporânea à fala de Perec - e que é apropriado repetir aqui: “[...] se prefiro a designação 'colagem' àquela de 'citação', é que a introdução do pensamento de outro, de um pensamento já formulado, nisso que escrevo, toma aqui, não mais valor de reflexo, mas de ato consciente, de passo decidido, para ir além desse ponto de onde eu parto, que era o ponto de chegada do outro." ([...] si je préfère l'appellation de collage à celle de citation, c'est que l'introduction de la pensée d'un autre, d'une pensée déjà formulée, dans ce que j'écris, prend ici, non plus valeur de reflet, mais d'acte conscient, de démarche décidée, pour aller au-delà de ce point d'où je pars, qui était le point d'arrivée d'un autre.) BERTELLI; RIBIÈRE. Nota 7. In: PEREC. Le bonheur est un processus... on ne peut pas s'arrêter d'être heureux. (1965). In: Entretiens et Conférences, 2003a, p. 49.

${ }^{226}$ Donc, on peut arriver à une espèce de littérature qu'on peut appeler expérimentale, qu'on peut appeler... citationnelle, par exemple. [...] Enfin, ce qu'il y a d'intéressant, c'est les relations de cette nouvelle littérature avec d'autres formes esthétiques. Je pense que ce type de littérature ressemble, enfin, a, ou entretient des rapports avec le pop art, avec une certaine forme du pop art, où il n'est jamais question que de peindre quelque chose qui a déjà été peint [...]. PEREC. Pouvoirs et limites du romancier français contemporain. (1967). In: Entretiens et conférences, 2003a, p. 86. 
procedimento como um mecanismo portador de certa autonomia, um aparato que, escolhido, programado e acompanhado, distanciava o escritor do resultado final e mudava seu estatuto enquanto produtor, deixando então de ser 'artesão' para se tornar 'operário'. Segundo Bernard Magné $^{227}$, a 'máquina', seguindo uma definição tirada do dicionário, é um objeto fabricado destinado a transformar a energia e a utilizar essa transformação. Designar a contrainte como 'máquina' é conferir a ela a tarefa de transformar um material por meio de um processo calculável e programável em um objeto novo. No caso da obra perequiana, explica Magné, a matéria que abastece a contrainte e que deverá ser transformada é a língua através da sua dimensão material: "é, antes de qualquer coisa, o aspecto gráfico, a letra, a marca tipográfica [...]. Daí o interesse de Perec pelo lipograma ${ }^{228}$, pelo palíndromo ${ }^{229}$, pelo tautograma ${ }^{230}$, e, mais genericamente, pelo anagrama ${ }^{231}$ sob todas as suas formas [...]" 232.

Foi durante as reuniões do OuLiPo, quando se discutia o uso de contraintes ao longo da história da literatura, que Perec se interessou pelo lipograma, sendo informado que a produtividade dessa contrainte (como de outros tipos de processos restritivos) estava relacionada à escolha que se fazia da letra a ser excluída para a sua construção: quanto mais presente essa letra estivesse na língua na qual o lipograma seria escrito, mais desafiador e produtivo seria a aventura em realizá-lo. No caso da língua francesa, a letra que é usada com mais frequência é a letra 'e'. E Perec decidiu assumir esse desafio.

${ }^{227}$ MAGNÉ. Textus ex machina (de la contrainte considérée comme machine à écrire dans quelques textes de Georges Perec). In: Perecollages, 1989, pp. 219-229.

${ }^{228}$ LIPOGRAMA: poema ou prosa composto de maneira a evitar o uso de uma ou mais letras. Cf. GORP et al.. Dictionnaire des Termes Littéraires, 2005, p. 278. Uma variação do lipograma é o monovocalisme [monovocalismo] praticado por Perec: um lipograma de onde foram retiradas todas as vogais, com exceção de uma. Cf. Monovocalismo em 'a' in: PEREC. What a man! In: OULIPO. Atlas de littérature potentielle, 2003b, pp. 214-216.

${ }^{229}$ PALÍNDROMO: forma particular de anagrama, palavra ou texto que pode ser lido indiferentemente da esquerda para a direita como no sentido inverso conservando o mesmo sentido. Cf. GORP et al.. Op. cit., p. 344. O grande palíndromo escrito por Perec com mais de 5000 letras tem por título: 9691 Edna d'Nilu O. Mú, Acéré. Pseg Roeg. Cf.: PEREC. Palindrome. In: OULIPO. La littérature potentielle, 2003a, pp. 97-102; PEREC. Palindrome. In: La clôture et autres poèmes, 1980, pp. 43-53.

${ }^{230}$ TAUTOGRAMA: poema em que todas as palavras se iniciam com a mesma letra. HOUAISS, Dicionário Eletrônico, 2009.

${ }^{231}$ ANAGRAMA: construção que inverte ou troca as letras de uma palavra ou de um grupo de palavras para tirar daí um sentido novo. Cf. GORP et al.. Op. cit., pp. 32-33. Um exemplo de anagrama é Ulcérations [Ulcerações]: uma série de 399 variações da palavra 'ulcérations', escrita e publicada por Perec pela primeira vez em 1974 como parte da Bibliothèque oulipienne. Cf. PEREC. Ulcérations. In: . $\mathrm{La}$ clôture et autres poèmes, 1980, pp. 55-67.

${ }^{232}[\ldots]$ c'est avant tout l'aspect graphique, la lettre, le caractère typographique [...]. D'où l'intérêt de Perec pour le lipogramme, le palindrome, le tautogramme, et plus généralement pour l'anagramme sous toutes ses formes [...]. MAGNÉ. Op. cit., p. 220. 
Inicialmente, ele adotou essa contrainte como um jogo no qual ele desafiava seus amigos a compor suas falas nas mais diversas situações e locais excluindo sempre a letra 'e'. Segundo Bellos ${ }^{233}$, conforme Perec foi se entusiasmando com a receptividade daqueles que tomavam contato com seu desafio, ele começou a levantar todo um léxico, pequenos relatos e também algumas 'traduções lipogramáticas' de poemas famosos que poderiam ser usados em um novo livro que acabaria se chamando La disparition [O desaparecimento].

A fábula contada em $\mathrm{La}$ disparition é o desaparecimento de um homem chamado 'Anton Voyl' - cujo sobrenome faz pensar na palavra francesa 'voyelle' [vogal]. Agora, na escrita do livro, além de seguir à risca as regras do lipograma, Perec também fez uso da colagem, não mais como forma de continuação de uma tradição literária, mas para incluir em seu texto as contribuições (na forma de textos e 'traduções') que ele havia recebido de amigos e colegas do OuLiPo (sem nunca citar o nome desses contribuidores).

Como exemplo dessa 'escrita da falta', apresento aqui as duas últimas páginas de $L a$ disparition (fig. 5) com tradução de Carlos Spilak - que segue à risca a contrainte original do livro:

Sim, afirmou Aloysius Swann, agora atingimos o final, a última palavra, do sinuoso circuito labiríntico no qual caminhamos com um passo sonâmbulo. Cada um proporcionou sua contribuição, sua participação. Cada um, avançando no mais profundo do obscuro do não-dito, urdiu ao máximo, a configuração dum discurso o qual, ao dilatar pouco a pouco, só abolia o acaso do outrora pagando o custo dum futuro surgindo insoluto, como um fanal iluminando só por um curto lapso a porção dum caminho, proporcionando assim ao fugitivo só uma marca mínima, um fio d'Ariana rompido ainda uma volta, autorizando só um passo por turno. Franz Kafka outrora já falara disso: há um alvo, mas não há caminho algum: chamamos caminho nossas dúvidas. Avançamos todavia, aproximávamo-nos a cada hora do ponto final, pois havia obrigação dum ponto final. Numa ou noutra ocasião, supúnhamos possuir a luz: havia dum modo continuado um "isso" para garantir um "Qual?", um "outrora", um "agora", um "ainda", justificando um "Quando?", um "pois" dando a razão dum "Por qual motivo?".

Mas sob uma ou outra solução transluzia ainda a ilusão duma cognição total, da qual fui probo procônsul, a qual nunca supôs o patrimônio único dum ou outro, ou dos protagonistas, ou do autor, ou d'mim próprio, forçando-nos assim a discursar dum modo infindo, nutrindo a narração, urdindo o próprio fio idiota, dilatando o próprio blablablá inútil, nunca atingindo o insultador ponto cardinal, a linha horizontal, o infinito no qual tudo insinuava a união total, no qual havia ilusão duma solução,

mas aproximando-nos, dum passo, dum micron, dum angström, do lapso fatal, no qual,

não dispondo mais para nós do ambíguo concurso dum discurso o qual, tudo junto, nos unia, nos constituía, nos traía,

o óbito,

o óbito com dígitos brônzios,

${ }^{233}$ BELLOS. Georges Perec, 1994, pp. 420-421. 
o óbito com dígitos frouxos,

o óbito no qual vai afundando a inscrição,

o óbito, o qual garantiu, ao infinito, a imaculação dum Álbum o qual um bufão um dia imaginou possuir habilitação para turvar,

o óbito nos ditou o fim da narração.

- Ainsi donc, dit la Squaw, voici sonnant l'instant du Finis Coronat Opus? Voici la fin du roman? Voici son point final?

Oui, affirma Aloysius Swann, voici parcouru jusqu'au bout, jusqu'au fin mot, l'insinuant circuit labyrinthal où nous marchions d'un pas somnambulant. Chacun, parmi nous, offrit sa contribution, sa participation. Chacun, s'avançant plus loin dans l'obscur du non-dit, a ourdi jusqu'à sa saturation, la configuration d'un discours qui, au fur qu'il grandissait, n'abolissait l'hasard du jadis qu'au prix d'un futur apparaissant sans solution, à l'instar d'un fanal n'illuminant qu'un trop court instant la portion d'un parcours, lors n'offrant au fuyard qu'un jalon minimal, fil d'Ariana toujours rompu, n'autorisant qu'un pas à la fois. Franz Kafka l'a dit avant nous : il y a un but, mais il n'y a aucun parcours; nous nommons parcours nos dubitations.

Nous avancions pourtant, nous nous rapprochions à tout instant du point final, car il fallait qu'il y ait un point final. Parfois, nous avons cru savoir : il y avait toujours un "ça" pour garantir un "Quoi?", un "jadis", un "aujourd'hui", un "toujours", justifiant un "Quand?", un "car" donnant la raison d'un "Pourquoi ?".

Mais sous nos solutions transparaissait toujours l'illusion d'un savoir total qui n'appartint jamais à aucun parmi nous, ni aux protagons, ni au scrivain, ni à moi qui fus son loyal proconsul, nous condamnant ainsi à discourir sans fin, nourrissant la narration, ourdissant son fil idiot, grossissant son vain charabia, sans jamais aboutir à l'insultant point cardinal, l'horizon, l'infini où 304

tout paraissait s'unir, où paraissait s'offrir la solu-

\author{
mais nous approchant, d'un pas, d'un micron, \\ d'un angström, du fatal instant, où, \\ n'ayant plus pour nous l'ambigu concours d'un \\ discours qui, tout à la fois, nous unissait, nous \\ constituait, nous trahissait, \\ la mort, \\ la mort aux doigts d'airain, \\ la mort aux doigts gourds, \\ la mort où va s'abîmant l'inscription, \\ la mort qui, à jamais, garantit l'immaculation d'un \\ Album qu'un histrion un jour a cru pouvoir noir- \\ cir, \\ la mort nous a dit la fin du roman.
}

Figura 5 - Georges Perec. La disparition, 2004b, pp. 304-305.

Nesse trabalho, além de ter uma pequena amostra da invisibilidade da contrainte, também é possível acompanhar o trabalho do escritor com a materialidade do texto (fig. 5). Quando chegamos ao final da página 304, o fluxo do texto é interrompido após a vírgula, sendo retomado na página seguinte, não como uma nova frase, mas como a continuação do parágrafo anterior, já que a palavra está em letras minúsculas. Conforme o texto avança, surgem novos espaços em branco que, pelo fluxo do texto, passam a explicitar que ocorre ali uma série de desaparecimentos: as palavras estão sumindo! O surpreendente é que essa série de desaparecimentos não abala a formatação/passividade geral do bloco de texto, nem mesmo quando surge à esquerda um empilhamento com a palavra 'mort' [morte], traduzida por 
Spilak por 'óbito'. As palavras sumiram ao mesmo tempo em que 'a morte' se fez presente e o romance continuou seu fluxo em direção ao ponto final: o fim.

Esse era o tipo de destaque que Perec conferia à materialidade da palavra para ir, citando uma frase do próprio texto: "avançando no mais profundo do obscuro do não-dito". 234

Todas as falas de Perec sobre o livro publicado em 1969 só faziam pensar no grande desafio linguístico que ele havia realizado: compor uma narrativa com 305 páginas sem o uso da letra 'e'. Numa conferência, ele aborda assim esse feito:

O livro sem "e" fala de um livro sem "e"; o assunto do livro sem "e", é o desaparecimento do "e". [...] eu parti da impossibilidade de escrever uma frase sem "e". [...] um inglês tinha feito, era necessário reascender a chama, e assim era necessário tentar. Era impossível. Então, se começa por fazer exercícios de tradução. O domínio da tradução é um domínio realmente fácil, já que se tem um guia, enfim, eu quero dizer, tem-se toda uma série de coisas que estão lá para ajudálo. ${ }^{235}$

O livro deveria aguardar ainda alguns anos para que fosse possível aos leitores reconhecer ali novos significados. Pouilloux ${ }^{236}$ reconhece em La disparition o primeiro trompe-l'œil ${ }^{237}$ realizado por Perec e que só se revelaria como tal - como uma obra ambígua ligada à biografia do autor e que tinha na virtuosidade um disfarce - após a publicação de outros dois livros do escritor.

A obsessão pela letra 'e' seria reapresentada aos leitores, agora de maneira oposta ao que ele havia feito em La disparition, quando Perec publica em 1972 Les revenentes [As aparições], um texto de 127 páginas que mistura romance policial com romance erótico, que é

${ }^{234}$ [Chacun,] s'avançant plus loin dans l'obscur du non-dit [...]. PEREC. La boutique obscure, 1993, p. 304.

${ }^{235}$ Le livre sans "e” parle d'un livre sans "e”, le sujet du livre sans "e”, c'est la disparition du "e”. [...] je suis parti de l'impossibilité d'écrire une phrase sans " $e$ ”. [...] un Anglais l'avait fait, il fallait relever le flambeau, et puis il fallait essayer. C'était impossible. Donc on commence par faire des exercices de traduction. Le domaine de la traduction est un domaine tout à fait facile, puisqu'on a un guide, enfin, je veux dire, on a toute une série de choses qui sont là pour vous aider. PEREC. À propos de la description. (1981). In: RENIER. Espace \& Représentation, 1989, p. 339.

${ }^{236}$ POUILLOUX. Histoires d'E. In: Magazine littéraire, 1983, p. 25.

${ }^{237}$ TROMPE-L'CEIL: “A definição de um trompe-l'œeil é aparentemente simples: é um jeito de pintar uma coisa de maneira que essa coisa não pareça pintada, mas verdadeira; ou, se preferimos, é uma pintura que se esforça em imitar a ponto de enganar o real." (La définition d'un trompe-l'œil est apparemment simple: c'est une façon de peindre quelque chose de manière que cette chose ait l'air non peinte, mais vraie; ou, si l'on préfère, c'est une peinture qui s'efforce d'imiter à s'y méprendre le réel.). PEREC; WHITE, 1987, s/ nº p.. 
um lipograma envolvendo as letras 'a', 'i', 'o', 'u' e que, exatamente por isso, é todo escrito com uma única vogal, exatamente a letra 'e' ${ }^{238}$.

Mas é em 1975, com $W$, que Perec dá um sentido para as contraintes que envolviam a supressão (a morte) do(s) 'E'(s). Nesse livro, Perec trata pela primeira vez da morte trágica dos pais durante a sua infância: Icek Judko Perec morre no campo de batalha na Polônia e Cyrla Szulewicz morre num campo de concentração. Na dedicatória do livro, Perec escreveu: "pour E” [para E] - onde a letra 'e' aparece em maiúscula e sem o ponto final. Bernard Magné explica assim essa convergência entre as três obras:

Escrever sem E, viver sem 'eles" ${ }^{239}$ : a dedicatória de $W$ ou a lembrança da infância ("Para E”) sugerirá mais tarde essa equivalência homofônica. O lipograma em E, é a contrainte do órfão, aquela que bane toda a presença do "pai" ${ }^{240}$ e da "mãe" ${ }^{241}$, na narrativa que indica portanto uma saga familiar. ${ }^{242}$

Eu ampliaria o espectro do que Magné chama de 'contrainte do órfão' para o que poderia ser uma 'contrainte do fantasma' ou 'contrainte do espírito' salientando que, sem a letra 'e', estavam proibidas tanto as palavras 'pai' e 'mãe', como o próprio nome do escritor. Esse apagamento total do 'nome da pessoa' se efetivaria em 1982, quando Georges Perec morre sem deixar descendentes. O que permanece é o nome do escritor.

O ano de 1975 é marcante para Perec, pois é quando ele esgota sua necessidade de recuperar uma infância/um passado/um amor perdidos: ele publica $W$, encerra seu terceiro período de análise ${ }^{243}$, abandona definitivamente o projeto de Lieux, deixa para trás os grandes

${ }^{238}$ É importante notar que Perec escreve a palavra 'revenantes' com a grafia errada, trocando a letra 'a' por 'e', fazendo com que ela esteja escrita na maneira como se fala. O livro está repleto desses desvios ortográficos. Antes do início da narrativa, o autor incluiu uma contrainte de leitura - o que pode ser entendido como um 'manual de isntruções do leitor', composto por três regras: “1. 'Qu' se escreve 'Q' [...] (Decisão do OuLiPo, sessão de 7 de março de 1972); 2. Usos [...] raros de 'Y' serão tolerados [...]; 3. Diversos tipos de distorções [...] serão mais ou menos progressivamente admitidos no curso do texto." (1. "Qu" s'écrit " $Q$ " [...] (Décision de l'OuLiPo, séance du 7 mars 1972); 2. Des rares [...] emplois du "Y” seront tolérés [...]; 3. Divers types de distorsions [...] seront plus ou moins progressivement admis au cours du texte.) Cf. PEREC. Les revenentes. In: Romans \& Récits, 2004c, p. 567.

${ }^{239} \mathrm{O}$ pronome tônico na terceira pessoa do plural em francês se escreve 'eux' [eles] e sua pronúncia é semelhante à da vogal 'e'.

${ }^{240}$ A palavra 'pai' em francês é 'père'.

${ }^{241}$ A palavra 'mãe' em francês é 'mère'.

${ }^{242}$ Écrire sans E, vivre sans eux: la dédicace de W ou le souvenir d'enfance ("Pour E”) suggérera plus tard cette équivalence homophonique. Le lipogramme en E, c'est la contrainte de l'orphelin, celle qui bannit toute présence du "père" et de la "mère", dans le récit qui relève pourtant d'une saga familiale. MAGNÉ. Notice. (La Disparition). In: PEREC. Romans \& Récits, 2004c, p. 308.

${ }^{243}$ Georges Perec fez análise em três momentos de sua vida: primeiro com Françoise Dolto (1949), depois com Michel de M’Uzan (1956) e, por fim, com Jean-Baptiste Pontalis (entre 1971 e 1975). 
projetos autobiográficos e inicia a escrita de La Vie mode d'emploi - seu grande 'romance(s) ${ }^{244}$ - e o primeiro volume do projeto 'As coisas comuns': Je me souviens.

Antes de passar diretamente à produção perequiana referente às coisas comuns, eu volto o foco da pesquisa para explorar a correspondência que Perec fazia entre o que ele chamava de 'literatura citacional' e a Arte Pop americana. É no território americano onde encontro a obra de Joe Brainard e sua maneira de lidar com a memória, com o refugo urbano, com a colagem e com um novo tipo de sistematização do material apreendido do mundo contemporâneo: a coleção.

\subsection{As coisas do Pop, ou, um objeto de segunda mão}

A Arte Pop é gostar de coisas. Andy Warhol ${ }^{245}$

Ao mesmo tempo em que os artistas franceses do Nouveau Réalisme se voltavam para o espaço urbano e para os objetos do cotidiano, frutos da indústria de massa, vários artistas na Inglaterra e nos Estados Unidos também buscavam novas maneiras de se referir à realidade imediata vivenciada nas grandes cidades da era industrial, observando, se apropriando e explorando diferentes aspectos do folclore, da paisagem e do cotidiano urbano.

O termo 'Pop Art' [Arte Pop] havia surgido na Inglaterra nos anos cinquenta, servindo para indicar os produtos da comunicação de massa, mas acabou sendo utilizado pela crítica para designar uma grande variedade de iniciativas de artistas em tratar da sociedade de consumo como tema e/ou objeto para, como afirma Restany ${ }^{246}$, "desenvolver um novo senso da natureza moderna, industrial e urbana". De maneira diversa ao que ocorreu na França, onde

\footnotetext{
${ }^{244} \mathrm{O}$ gênero de La Vie mode d'emploi foi definido pelo próprio autor como 'Romans' [Romances]. Cf. PEREC. La Vie mode d'emploi, 1994b, p. 7.

${ }^{245}$ Andy Warhol apud LIPPARD. $O$ “Pop” de Nova Iorque. In: LIPPARD et al.. Arte Pop, 1976, p. 93.

${ }^{246}$ RESTANY. A Pop'Art. In: Os novos realistas, 1979, p. 131.
} 
o Nouveau Réalisme se configurava como grupo que produzia manifestos e tinha preocupações sociológicas, as iniciativas anglófonas eram mais autônomas e avessas a comentários sociais.

Mesmo tendo origem na Inglaterra, esse movimento se expandiu e se afirmou como linguagem artística madura nos Estados Unidos - em especial em Nova York -, onde, distante das consequências nefastas da Segunda Grande Guerra, podia-se usufruir de maneira positiva o crescimento econômico e a efervescência do consumo, já que ali não havia a preocupação em reconstruir ou suprir a falta do que havia sido perdido/subtraído anos antes.

Da mesma maneira que na França, a aproximação do real feita pela Arte Pop se dava em oposição ao expressionismo abstrato, chamado por Restany ${ }^{247}$ de 'arte da evasão' - força que lidava com as pulsões do indivíduo e seu mundo interiorizado -, e se voltava para uma 'arte da participação', na qual era possível compartilhar impressões e conhecimentos da vida do dia a dia. Na aproximação do real, também o artista americano recolhia ali 'pedaços de vida' para levá-los ao espaço da arte através de assemblages - expressão que guardava traços tanto da Vida (pelas marcas de usura) quanto da Arte (pelas referências a expressões mais antigas) e que no início parecia ser a própria manifestação Pop.

Fora esse primeiro exercício comum com a assemblage, a Arte Pop se distanciaria muito cedo do Nouveau Réalisme. Ainda que essas duas expressões trabalhassem com a descoberta de um folclore urbano, ensaiassem uma aproximação técnica/expressiva do universo industrial e não estivessem interessadas em desenvolver uma nova figuração, o que parecia fundamentar suas iniciativas era muito distinto. Se os Novos Realistas tinham um interesse sociológico, trabalhavam o estranhamento do objeto e exploravam com certa angústia o peso da história - chamado por Lippard ${ }^{248}$ de "sugestão de mistério", a Arte Pop estava interessada pelos artefatos de uma civilização industrial orientada pelo luxo, pela diversidade, pela quantidade e por uma imagem cinematográfica de felicidade que vinha há anos sendo configurada para ser o que se denominou 'The American Way of Life'. Através da Arte Pop os americanos descobriam a verdadeira natureza moderna americana - diferente do que ocorria em qualquer outro lugar e pleno de valores que os americanos reconheciam como seus. Lucy Lippard ${ }^{249}$ toma a obra de Warhol como exemplo do que se passava com vários artistas ligados a esse movimento:

\footnotetext{
${ }^{247}$ RESTANY. A Pop'Art. In: ___. Os novos realistas, 1979, p. 141.

${ }^{248}$ LIPPARD. Europa e Canadá. In: LIPPARD et al.. Arte Pop, 1976, p. 191.

${ }^{249}$ LIPPARD. O “Pop” de Nova Iorque. In: Ibidem, pp. 102-103.
} 


\begin{abstract}
Após a Segunda grande Guerra, as glândulas lacrimais do mundo secaram devido ao seu uso excessivo. É deste mundo que Warhol se faz porta-voz [...]. Talvez o motivo de os humanismos visuais da última década se terem grandemente malogrado, com a sua retirada horrorizada, o seu expressionismo atormentado ou o protesto de vítimas mutiladas, se deva ao fato de as suas bases supostamente universais não serem de modo algum partilhadas pela audiência. Uma vez que "toda a gente" compreende o processo de desumanização vivida e impessoalmente descrito por Warhol, a sua obra origina, muito provavelmente, uma atitude mais positiva do que a indignação justa daqueles que são 'contra' tudo o que se verifica no presente, e 'a favor' apenas de uma vaga, antiquada nostalgia.
\end{abstract}

Nesse exercício de aproximação de um real compartilhável e disponível a todos, os artistas Pop trabalhavam de maneira a encurtar as distâncias entre aquilo que faziam e o que podia ser visto e experimentado pelo público. É assim que, ao invés de inaugurar imagens que poderiam causar estranhamentos e demandariam certo tempo para serem apreendidas, esses artistas trabalhavam com imagens prontas, de reconhecimento imediato, tomadas dos meios de comunicação de massa como cartazes, outdoors, embalagens, reportagens impressas,

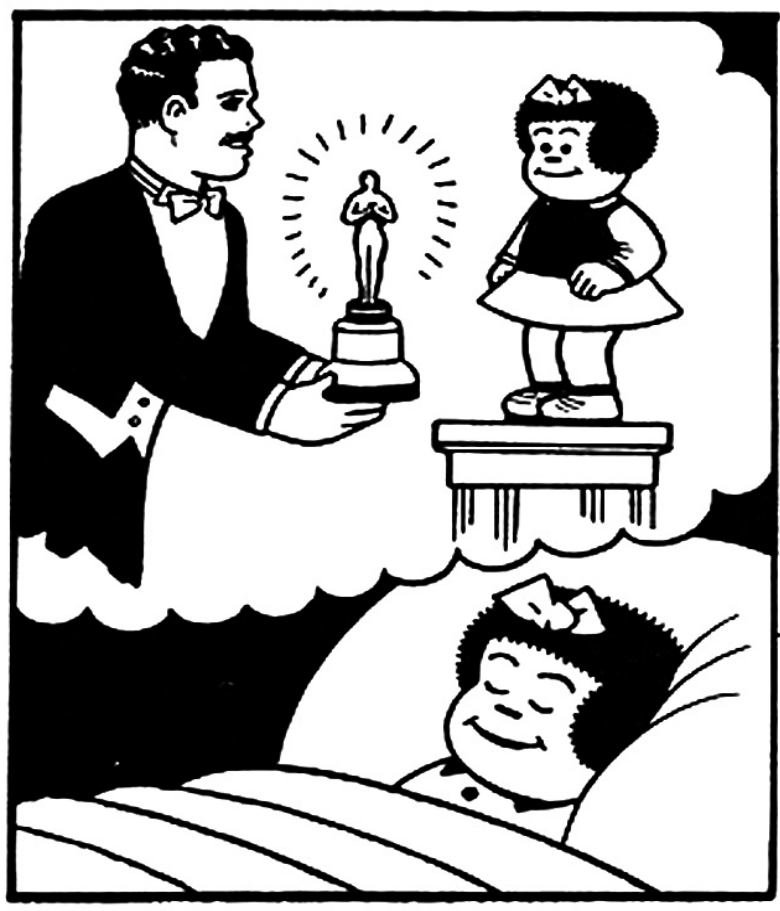

Figura 6 - Ernie Bushmiller. Nancy (detalhe) (23/04/1961).

fotografias de celebridades, histórias em quadrinho etc. Um exemplo disso é o trabalho de Andy Warhol, artista que Restany ${ }^{250}$ classificava como um dos 'paginadores da natureza moderna'. Isso pode ser observado num dos primeiros trabalhos de apropriação feitos por Warhol de figuras de histórias em quadrinhos: 'Nancy' - personagem criada por Ernie Bushmiller (1905-1982). Para comparar o que é o trabalho do artista nesse exercício de apropriação, cópia e exploração, apresento na fig. 6 um exemplo do trabalho de Bushmiller através do quadro de uma tira de uma de suas histórias publicada em 23/04/1961, e depois, na fig. 7, uma pintura feita por Warhol no mesmo ano. 
Aí o artista explorava, entre outras coisas, alguns procedimentos que seriam depois desenvolvidos por vários artistas ligados à Arte Pop: o exercício da cópia - o trabalho não era uma assemblage, mas a ampliação de um fragmento; o uso de um objeto absolutamente banal - uma tira de história em quadrinho - como modelo; e o comentário irônico presente na maneira de trabalhar a cor (conflitante com a natureza do objeto copiado), uma provável alusão à obra de Willem de Kooning - artista ligado ao expressionismo abstrato e um dos mais valorizados pelo sistema institucional da arte naquele momento.

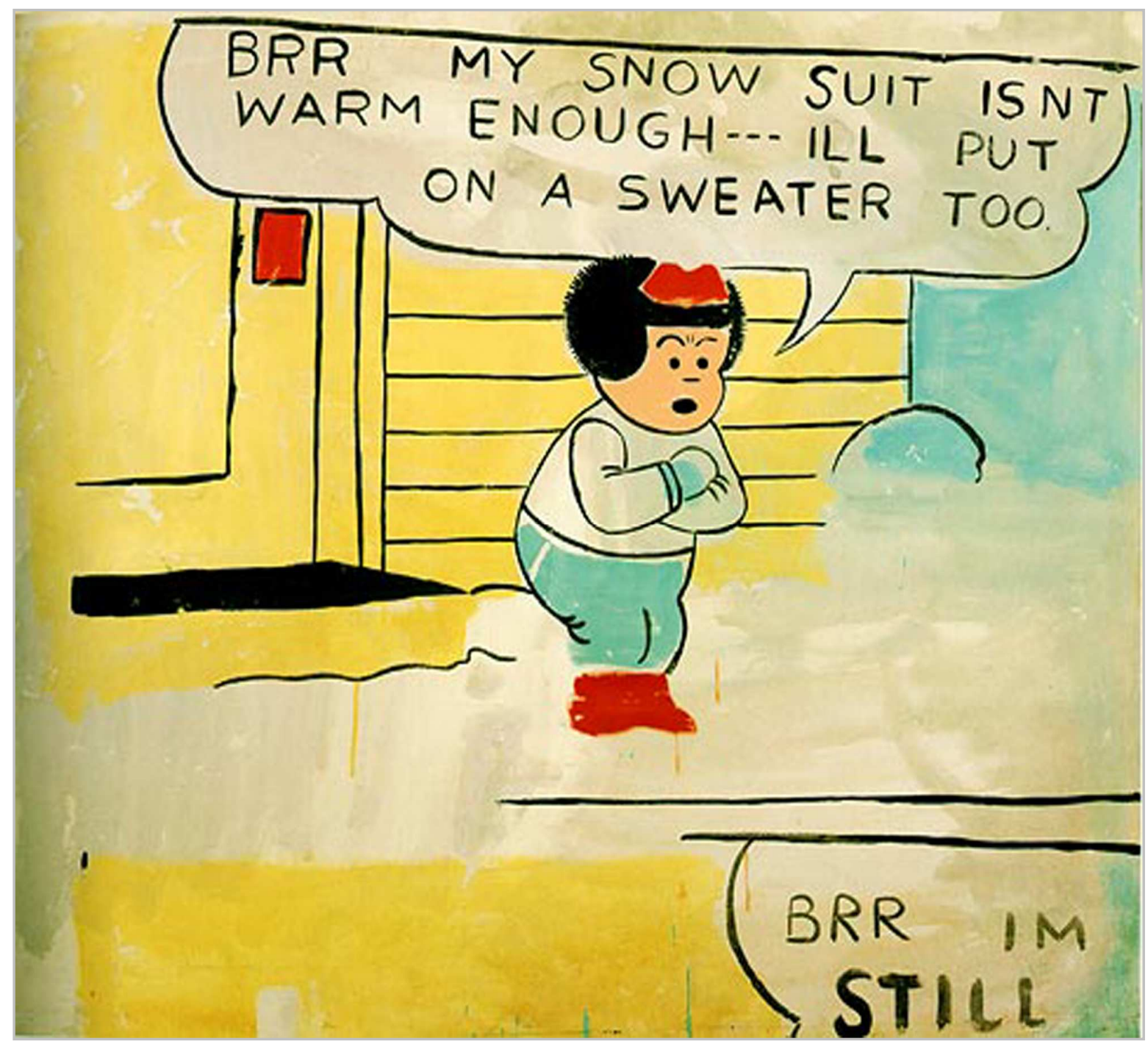

Figura 7 - Andy Warhol. Nancy (1961). Pintura c/ polímero sintético sobre tela. $101 \times 135 \mathrm{~cm}$. 
Esses artistas exploravam o que Restany ${ }^{251}$ chamou de 'ready-mades visuais', ou seja, imagens tomadas dos meios de comunicação de massa e tidas como elementos de uma linguagem inerente à cultura americana. Através delas, os artistas punham em prática alguns procedimentos que seriam incorporados definitivamente no campo da arte contemporânea como, por exemplo: o interesse pelo banal, o exercício da cópia, a transformação do objeto apreendido do real em modelo que seria amplificado e repetido à exaustão, além do recurso da ironia que servia tanto para criticar as instâncias oficiais/institucionais da arte naquele momento, como para questionar o valor e o interesse dos conteúdos da própria produção dos artistas Pop.

Mais adiante, os artistas Pop passaram a evitar o trabalho com objetos e materiais que trouxessem marcas de experiências anteriores ou que indicassem um tipo de aproximação pessoal particular, preferindo explorar aquilo que ali ainda estava por ser consumido. Dessa maneira eles se afastavam do que foi chamado no capítulo anterior de 'objeto biográfico' ${ }^{252}$, interessando-se por aquilo que Violette Morin ${ }^{253}$ chamou de 'objetos protocolares', ou ainda, de 'objets cosmocentrés' [objetos cosmocentrados]: objetos que haviam sido concebidos para um indivíduo-em-potencial, ou, um indivíduo-modelo, e não para um indivíduo-particular. Esse tipo de objeto, ainda segundo essa autora, era previsto para ter uma forma e uma eficiência que servissem e se adaptassem ao maior número de pessoas - essa seria a própria natureza do objeto moderno industrializado, seu grande trunfo. Além disso, segundo a mesma Morin, se o objeto biográfico era utilizado para demarcar e, portanto, limitar o espaço concreto do usuário, o espaço que caracterizaria o objeto protocolar seria da ordem do ilimitado e da liberdade - algo ainda por ser conquistado.

Agora, a imagem-objeto que os artistas Pop apresentavam ao observador sugeria algo da mesma ordem do que poderia ser encontrado no objeto protocolar, ou seja, uma 'imagem de desejo' - uma experiência semelhante àquela definida no primeiro estágio da 'Escala de Vida do Objeto' de Abraham Moles (apresentada no primeiro capítulo). Para isso, essas imagens-objeto passavam por um tratamento que reforçaria algumas características do objeto protocolar como, por exemplo: a impessoalidade, a atualização tecnológica, a condição de ser novo, a reprodutibilidade e a familiaridade.

\footnotetext{
${ }^{251}$ RESTANY. A Pop'Art. In: Os novos realistas, 1979, p. 135.

${ }^{252}$ Lucy Lippard cita uma explicação dada por Jim Dine para deixar de se preocupar com objetos achados: "havia neles demasiado mistério dos antigos proprietários". Cf. LIPPARD. O "Pop" de Nova Iorque. In: LIPPARD et al.. Arte Pop, 1976, p. 80.

${ }^{253}$ MORIN. L'objet biographique. In: Communications, 1969, pp. 136-137.
} 
O aspecto simples, os conteúdos divertidos, reconhecíveis e, de alguma forma, repousantes tratados pelos artistas Pop ajudavam a explicar, segundo Lippard, boa parte do sucesso da identificação do público com o movimento. Os artistas do Pop olhavam para o real, mas ao invés de se interessarem pela vida que transcorria ali, eles tomavam o que nos objetos era espelho e representação e que poderia ser encontrado tanto numa tira de quadrinhos quanto numa lata de sopa ou numa caixa de sabão em pó.

\subsubsection{Brainard: quando o material faz tudo}

O que mais me influenciou foram as vitrines de Nova York. Joe Brainard 254

Joe Brainard (1942-1994) chegou a Nova York no início dos anos sessenta vindo de Tulsa (Oklahoma) e foi muito marcado por duas exposições: The Art of Assemblage [A Arte da Assemblage] no Museu de Arte Moderna (1961) e New Realists [Novos Realistas] na galeria de Sidney Janis (1962). Nessas duas exposições era possível confrontar as maneiras como artistas norte-americanos e europeus enfrentavam a nova realidade urbana ${ }^{255}$. Brainard se identificou tanto com o que faziam os artistas ligados à assemblage e à colagem que ele também passou a praticar essas técnicas. Mesmo não fazendo parte de qualquer grupo ou movimento artístico, seus interesses iniciais coincidiam em muitos aspectos com o que seria chamado de Arte Pop e, poucos anos depois, seus trabalhos já eram incluídos em várias mostras dedicadas a esse movimento.

Tudo na obra de Brainard é estonteantemente diversificado e excessivo: ele era fascinado pelo mundo material da cultura popular e, além de trabalhar compulsivamente com assemblages e colagens, ele também desenhava, pintava e escrevia. Ele nunca se limitava a

\footnotetext{
${ }^{254}$ I think what influence me most are the shop windows in New York. PADGETT, R.; PADGET, P. An Interview with Joe Brainard. (1967). In: LEW ALLEN. Joe Brainard, 2001, p. 96.

${ }^{255}$ Os artistas franceses do Nouveau Réalisme estiveram representados nas duas exposições. Pierre Restany entende que a exposição de 1962 foi de suma importância para todos os artistas envolvidos na construção de uma nova cultura urbana e explica que foi, após essa exposição, que se formou o verdadeiro American New Realism, primeiro passo para o que configuraria a Arte Pop - um estilo verdadeiramente americano. Essa exposição, ainda segundo o crítico, teria sido essencial para que os artistas franceses pudessem entender e tomar consciência da amplidão de tudo o que envolvia a exploração da nova realidade urbana bem como do quanto era singular e importante o trabalho do Nouveau Réalisme. Cf. RESTANY. O Encontro Paris - Nova York. In: Os Novos Realistas, 1979, pp. 123-127.
} 
trabalhar uma única técnica, com um único tipo de material ou numa única série e, paralelamente ao seu trabalho pessoal, ele também ilustrava e fazia capas para livros.

Como característica importante do seu trabalho inicial, cito seu interesse pelo pequeno e pelo insignificante que o artista colhia nas ruas. Para Carter Ratcliff :

\begin{abstract}
Brainard retratou seu mundo em detalhes tão minuciosos que só leva um pouco de tempo para perceber que seu objetivo é celebrar a pura ideia do detalhe, do particular na sua inexaurível particularidade. Ele recomenda que nós nos sintamos à vontade no meio das coisas, não apenas de objetos produzidos em série como frascos de xampu, como de objetos produzidos por mãos despretensiosas. [...] Atraído pela imagem, Brainard se satisfazia às vezes apenas duplicando-a com uma precisão afetuosa. Geralmente, ele reformava as imagens que encontrava num material impresso e na rua, ou dava a elas novos ambientes em suas colagens. [...] $\mathbf{O}$ mundo de Brainard tem um sabor doméstico, um aconchego que de vez em quando se abre para vistas ilimitadas. ${ }^{256}$
\end{abstract}

Além desse trabalho com as artes visuais, ele também escrevia junto com seus amigos poetas e aproveitava para utilizar fragmentos dos manuscritos que escreviam para compor novas colagens. Seus amigos poetas faziam parte da Escola de Nova York e, segundo Constance M. Lewallen ${ }^{257}$, compartilhavam uma mesma metodologia: nunca partir de uma ideia preconcebida e seguir aquilo que, através do acréscimo de palavras e/ou matérias, pode ser entendido como a indicação de um trajeto. Brainard pensava o seguinte sobre isso:

Eu não tenho uma ideia. O material faz tudo. Você tem uma figura e uma flor e você acrescenta uma vista da cidade e a história está pronta. Você tem o controle se quiser, mas isso é uma coisa que nunca me interessou muito. Quero dizer que, se surgisse uma história, eu até poderia segui-la, mas eu nunca me interesso por ler ou fazer deliberadamente uma história. Na verdade, acho que não conseguiria. É o mesmo problema que eu teria se quisesse escrever um romance. Eu sei que nunca estabeleceria um plano porque o único tipo de plano, em qualquer sentido dessa palavra, tanto para a escrita quanto para a pintura, que eu alguma vez fui capaz de apresentar surgiu nele mesmo a partir de uma palavra para a próxima ou de uma coisa para a próxima. ${ }^{258}$

${ }^{256}$ Brainard pictured his world in such minute detail that it takes only a little while to realize that its guiding purpose is to celebrate the very idea of detail, of the particular in its inexhaustible particularity. He recommends that we take lively comfort in the sheer profusion of things, not only mass-produced objects like bottles of shampoo but objects produced by unpretentious hands. [...] / Attracted by an image, Brainard was sometimes content simply to replicate it with fond precision. Usually, he revamped the images he found in the media and the street, or gave them new settings in his collages. [...] Brainard's world has a domestic flavor, a coziness that now and then opens onto boundless vistas. RATCLIFF. Attending to the ordinary. In: Art in America, 1997, p. 74.

${ }^{257}$ LEWALLEN. Acts of Generosity. In: ___ Joe Brainard, 2001, p. 12.

${ }^{258}$ I don't have an idea. The material does it all. You have a figure and a flower and you add a cityscape and it makes the story. You have control if you want to take it but that's something I never wanted to do much. I mean if a story came out I'd sort of follow it, but I never want to read or make a story deliberately. In fact I 
Desse modo, sem projeto, o artista tinha como ponto de partida o objeto/imagem apropriado do real e jogado ali. Por causa disso, Brainard precisava guardar consigo uma quantidade enorme de material para que, iniciada a obra, ele tivesse à sua disposição o que fosse necessário para a continuação de um trabalho que se insinuava a partir dos objetos a sua frente. É assim que uma grande desordem tomava conta do seu estúdio (fig. 8) - definido por Brad Gooch como "“um cesto de reciclagem' de detritos urbanos”. ${ }^{259}$

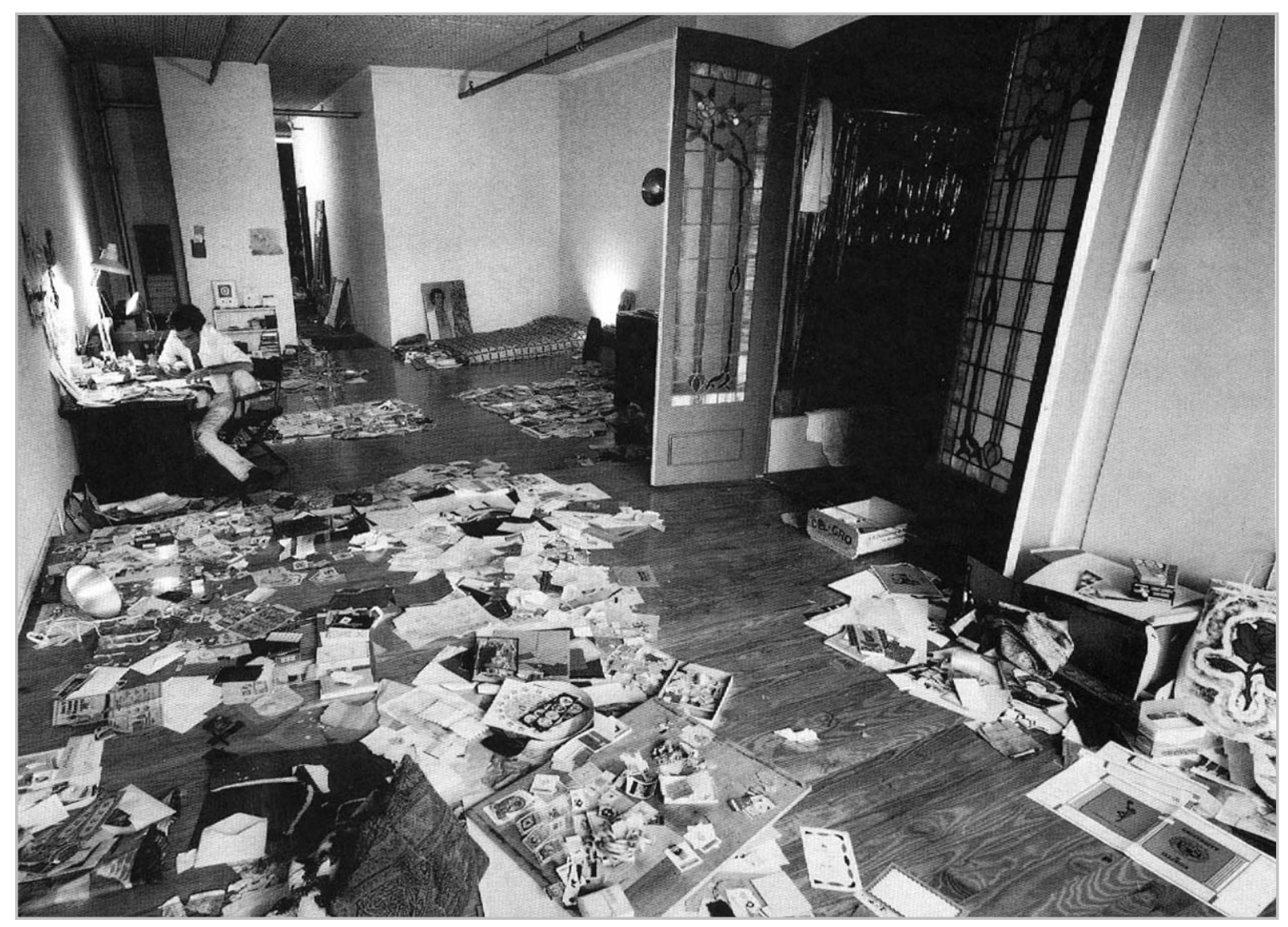

Figura 8 - Joe Brainard em seu apartamento, Nova York (1975).

Apesar de um início bastante promissor junto à Arte Pop nos anos sessenta, seu trabalho na década seguinte ainda permanecia preso aos primórdios do movimento, principalmente por sua insistência em continuar fazendo colagens que, junto com a assemblage, já haviam sido abandonadas por boa parte dos artistas. Essas duas técnicas eram anacrônicas com a expressão do novo, do tecnológico e do impessoal, forças instigadoras de

don't think I could. It's the same trouble I'd have if I wanted to write a novel. I know I would never plan a plot because the only kind of plot in any sense of the word in either writing or painting that I've ever been able to present has come in itself from one word to the next or one thing to the next. WALDMAN. $\underline{A n}$ interview with Joe Brainard. (1979). In: LEWALLEN. Joe Brainard, 2001, p. 102.

${ }^{259}$ A “recycle bin” of urban detritus. GOOCH. Nancy ideas. In: Artforum International, 2001, p. 126. 
desejo no observador/consumidor, tão propagadas pelo Pop. O produto apresentado por Brainard estava carregado não só de vestígios de um passado particular, como ainda expunha um manuseio acanhado da matéria, no qual se revelava um fazer doméstico, muito longe dos trabalhos de outros artistas que faziam pensar numa linha de produção industrial e o exercício da fábrica.

Brainard nunca se importou em definir e/ou respeitar limites para a sua produção criativa. É assim que ele sempre transitou entre os meios literários e artísticos nova-iorquinos com igual interesse e isso pode ter sido determinante para as escolhas feitas pelo artista que, se o afastaram da Arte Pop, acabaram por aproximar sua produção do que Georges Perec e seus colegas da revista Cause commune estavam propondo no início dos anos setenta na França: uma maneira de ter acesso ao infraordinário, ao cotidiano.

Brad Gooch, poeta e escritor que conheceu Brainard nos anos setenta, indica que naquele momento o trânsito da obra de Brainard entre artes visuais e poesia parecia ser mais favorável à sua escrita do que à sua produção visual. Gooch entendia a obra desse artista como parte do 'sistema da poesia' e que Brainard "não era um pintor dos pintores; ele era um pintor dos poetas." 260

Como já indiquei anteriormente, Brainard tinha uma ligação forte com vários poetas da Escola de Nova York, em especial com Frank O’Hara (1926-1966), com quem fez vários trabalhos em parceria. Exemplo disso é a colagem sem título de 1964 (fig. 9) onde, além de explorar um tipo de estética casual das ruas que se dá pela sobreposição de diferentes camadas de informação e de matéria, também já é possível reconhecer a presença da mesma Nancy personagem de histórias em quadrinho apropriada por Warhol anos antes. Ainda que esse tipo de apropriação fosse muito comum entre os artistas Pop, a maneira de Brainard trabalhar com esse material, mantendo sua escala diminuta e colocando-o em contato com outros materiais, acompanhava mais o que faziam os poetas do que os artistas novaiorquinos mais arrojados.

\footnotetext{
${ }^{260}$ He wasn't a painter's painter; he was a poet's painter. GOOCH. Nancy ideas. In: Artforum International, 2001, p. 126.
} 


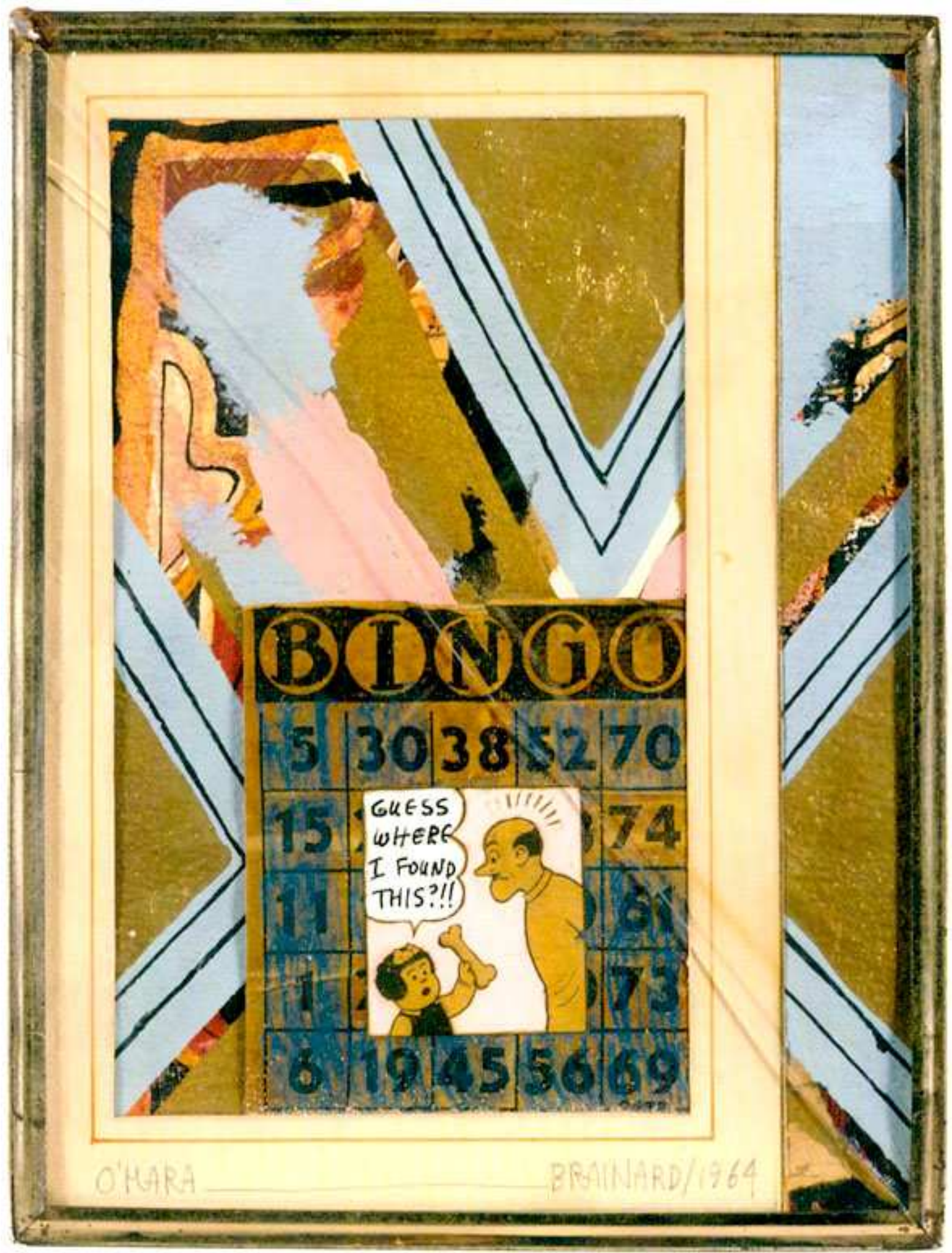

Figura 9 - Joe Brainard e Frank O'Hara. S/ título (Bingo, or "Guess where I found this?!!") [Bingo, ou "Adivinha onde eu encontrei isso?!!"], (1964). Colagem com técnica mista, $25,4 \times 20,3 \mathrm{~cm}$. 
Ann Lauterbach ${ }^{261}$, no texto que acompanha uma seleção de trabalhos de Brainard que tem Nancy como protagonista, escreve que os poetas da Escola de Nova York se movimentavam com frequência desde os anos cinquenta pelo campo das artes visuais, escrevendo críticas, incorporando referências de artistas e de obras plásticas em seus trabalhos, compartilhando também interesses e questionamentos semelhantes quanto à chamada 'cultura popular', seus elementos, seus símbolos e seus mitos. Tratando da segunda geração de poetas que havia sucedido àquela de Frank O'Hara (1926-1966), Lauterbach explica que "esses novos poetas aspiravam [...] a uma poética do cotidiano comum, imaginada como a sensibilidade da vida urbana que se passa nas ruas, com a mudança rápida de vistas, relances efêmeros e um bom humor autodepreciativo" ${ }^{262}$. Ainda, segundo Lauterbach, isso era feito por aquilo que O'Hara chamava de: "uma poesia do 'eu faço isso, eu faço aquilo",263. A obra de Brainard é um exemplo do hibridismo que frutivicava na cena artística nova-iorquina ao longo dos anos sessenta e setenta.

Assinalo ainda um trabalho de Brainard feito entre 1972 e 1975 que concentra vários dos seus interesses e que configura uma eloquente coleção de banalidades. É uma série feita em técnica mista (desenho, pintura, colagem), em dimensões que giram em torno do formato A4 (21 x 29,7 cm), na qual 'Nancy' participa de um tipo de fantasia que começa com os dizeres: “If Nancy...” [Se Nancy... $]^{264}$ (figs. 10, 11, 12 e 13).

O artista havia encontrado nela um ótimo canal de acesso ao cotidiano das pessoas: Nancy já fazia parte da vida diária dos americanos por meio de jornais e revistas há mais de três décadas, sempre envolvida em ações e acontecimentos cômicos, desimportantes e pouco complexos. Nancy não era bonita, não tinha idade definida, era gordinha, baixinha, um pouco ingênua, estava sempre sorrindo e pertencia a um lugar e tempo que poderiam ser qualquer um próximo da vida e do endereço dos seus leitores. Nancy fazia parte de um mundo no qual todo e qualquer acontecimento estava fragmentado em cenas simples, com poucos elementos, e que não durava mais do que uma passagem de olhos do leitor. A vida ali costumava ser tranquila e a finalização dos imprevistos em que ela se metia acabavam sempre com um

\footnotetext{
${ }^{261}$ LAUTERBACH. Joe Brainard \& Nancy. In: BRAINARD. The Nancy book, 2008, pp. 7-24.

${ }^{262}$ These young poets envisioned [...] a poetics of demotic dailiness, imagined as a sensibility or urban street life, quickly shifting perspectives, ephemeral glimpses, and self-deprecating good humor. Ibidem, p. 19.

263 "I do this, I do that" poetry. Ibidem, p. 19.

${ }^{264}$ Joe Brainard trabalhou com a imagem de Nancy ao longo de toda a sua carreira e a série 'If Nancy...' é a que melhor caracteriza uma 'coleção' em função do jogo que propõe, da estrutura das imagens sempre acompanhadas da mesma introdução, da regularidade do uso de certos procedimentos e tipos e dimensões do suporte das imagens.
} 
sorriso cúmplice do leitor que sabia que nada acabaria realmente ali e no dia/jornal/revista seguinte haveria sempre um pouco mais.

Lauterbach ${ }^{265}$ reconhece em Brainard um interesse particular pela miniatura e acredita que isso conferia a ele um poder especial sobre todas as coisas, já que através delas seria possível controlar e definir limites tanto para o que é transitório como para o que é visionário. É assim, como miniaturas, que essa autora entende cada uma das imagens propostas por Brainard em 'If Nancy...', onde, para garantir a clareza da mensagem, o autor precisou destilar a narrativa, congelar o tempo e delimitar o espaço.

O conteúdo de cada uma das imagens da série e a proposição de um jogo infinito decorre da perspicácia do autor que definiu a conjunção 'se' como o início das frases que dão título a cada trabalho. Lauterbach entende assim os desdobramentos disso:

O 'se' é uma palavrinha poderosa, pondo a realidade em suspensão, segurando o presente refém de um futuro consequente: 'Se isso, então aquilo'. 'Se' ergue uma pontezinha sobre o qual o presente se movimenta na direção tanto da esperança quanto do terror. [...] ' $S e$ ' liga o mundo dos desejos com o mundo dos fatos. 'Se Nancy fosse...' forneceu uma maneira para Brainard [e todos os seus leitores] negociar os limites escorregadios entre fantasia e realidade, interior e exterior, privado e público. $^{266}$

A partir dessa contrainte tão simples, todas as imagens de Nancy se tornam possíveis e o leitor/observador também poderia se sentir instigado a propor novas fantasias para a coleção de 'If $N a n c y(s)$ ' de Brainard. Mas o trabalho desse artista pode ser enganador e, no campo do 'se' - campo de todos os possíveis -, é preciso saber que entre tantas variações Brainard também incluiu trabalhos de teor pornográfico e agressivo. Nancy não poderia ser apenas uma 'boa menina'.

${ }^{265}$ LAUTERBACH. Joe Brainard \& Nancy. In: BRAINARD. The Nancy book, 2008, p. 15.

266 'If' is a powerful little word, lifting reality into suspension, holding the present briefly hostage to a consequential future: 'If this, then that'. 'If' erects a tiny bridge over which the present moves toward either promise or terror. [...] 'If' couples the world of wishes with the world of facts. 'If Nancy was...' provided a way for Brainard to negotiate the slippery boundaries between fantasy and reality, inner and outer, private and public. Ibidem, p. 20. 


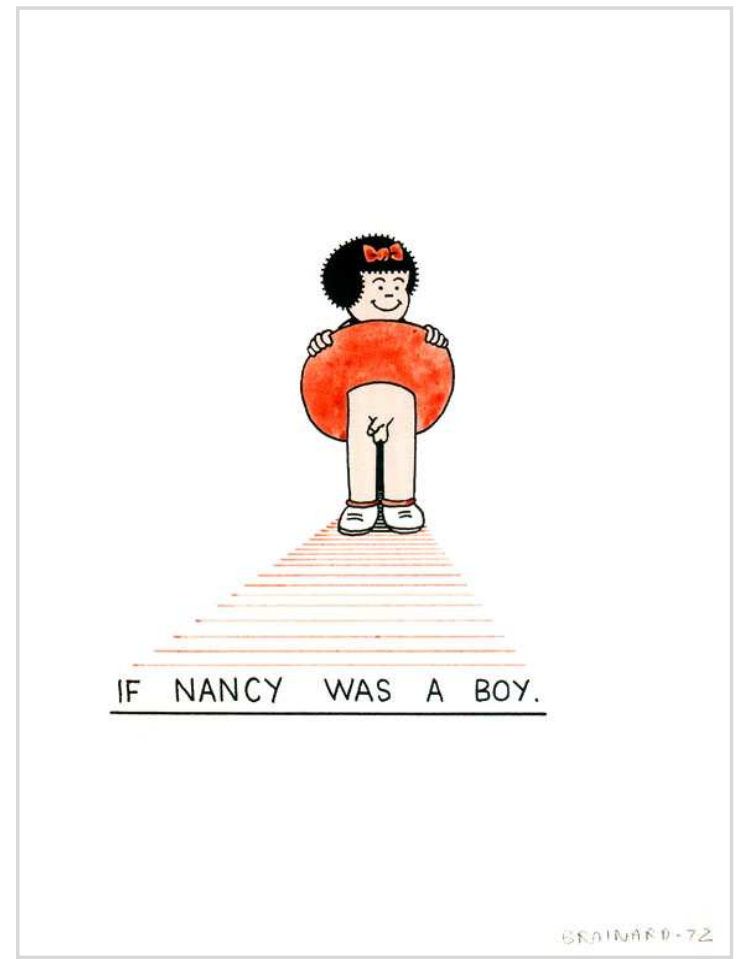

Figura 10 - Joe Brainard. If Nancy was a boy [Se Nancy fosse um menino] (1972). Guache e tinta sobre papel, $27,9 \times 20,3 \mathrm{~cm}$.

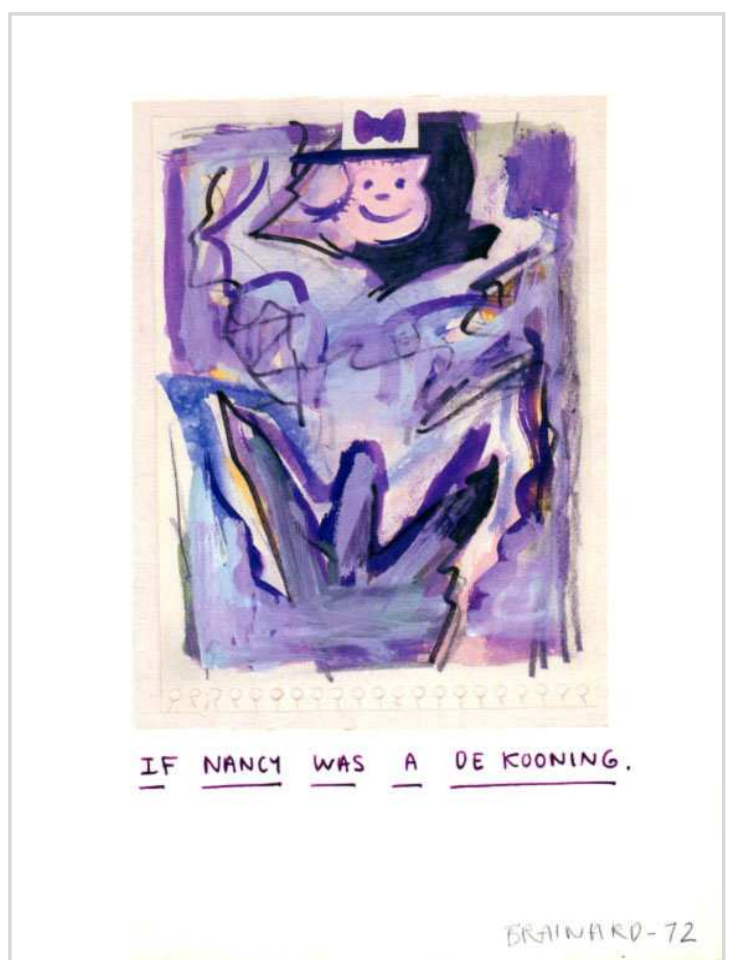

Figura 12 - Joe Brainard. If Nancy was a De Kooning [Se Nancy fosse um De Kooning] (1972). Técnica mista, 30,4 x $22,8 \mathrm{~cm}$.

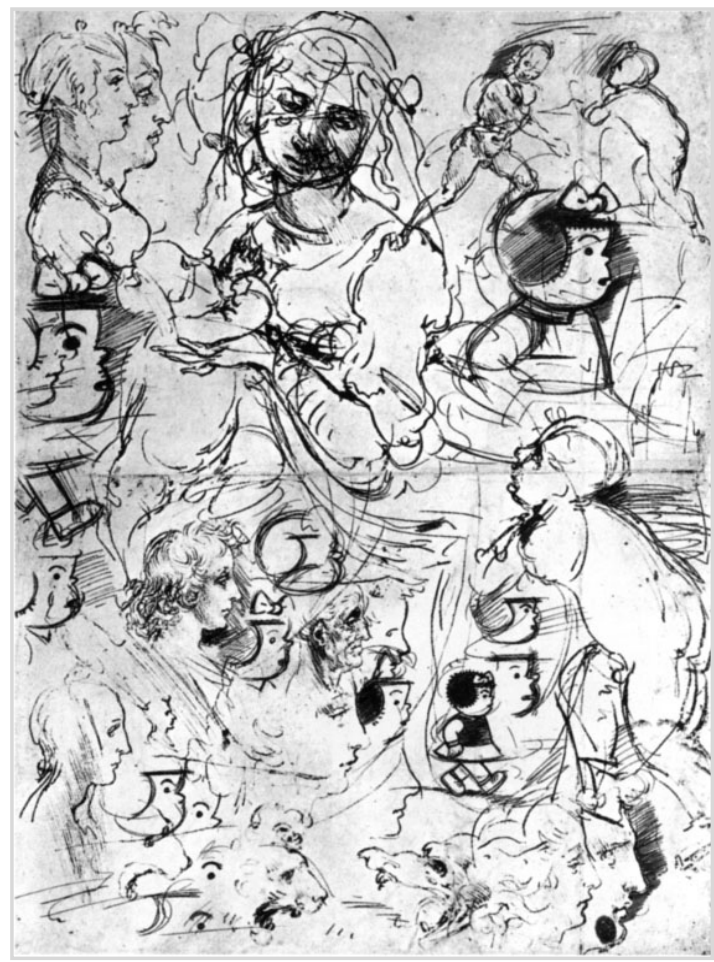

Figura 11 - Joe Brainard. If Nancy was a drawing by Leonardo da Vinci [Se Nancy fosse um desenho de Leonardo da Vinci] (1972). Tinta sobre página impressa de livro, $35,5 \times 26 \mathrm{~cm}$.

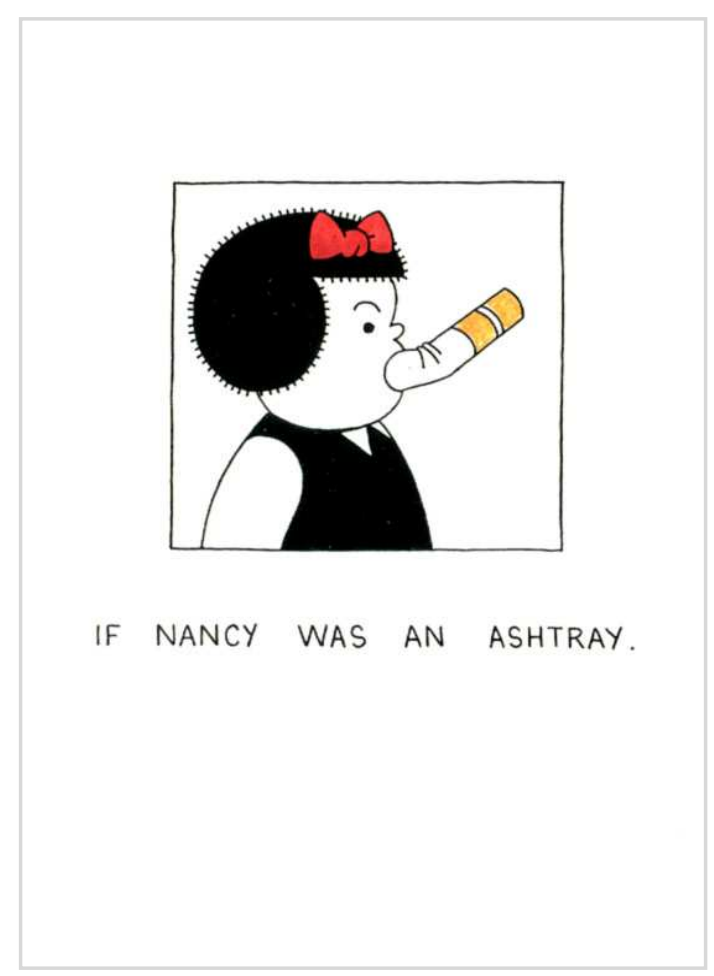

Figura 13 - Joe Brainard. If Nancy was an ashtray [Se Nancy fosse um cinzeiro] (1972). Guache sobre papel, 30,4 x 22,8 $\mathrm{cm}$. 


\subsection{O estatuto da coleção}

[...] toda paixão confina com um caos, mas a de colecionar com o das lembranças.

[...] o que é a posse senão uma desordem na qual o hábito se acomodou de tal modo que ela só pode aparecer como se fosse ordem?

Walter Benjamin ${ }^{267}$

Para tratar do que configura a coleção e como essa maneira de relacionamento com os objetos me ajuda a pensar as semelhanças/diferenças entre as produções de Perec e de Brainard, recorro às reflexões de dois interessados no assunto: Baudrillard, que nos decifra os mecanismos envolvidos no exercício de posse dos objetos, e Walter Benjamin, que discorre sobre sua própria experiência de colecionador de livros.

Baudrillard ${ }^{268}$ reconhece que muitos objetos, fora da prática que normalmente temos deles - isto é, fora do exercício da sua funcionalidade -, podem se tornar o alvo de uma paixão humana, deixando de servir a algo para servir a alguém. Ele afirma então que todo objeto tem duas funções: a de ser utilizado e a de ser possuído. O objeto prático, chamado por ele de 'utensílio', é aquele que desaparece atrás do que está programado para executar, não podendo ser possuído porque visa um fim que serve às relações e práticas compartilhadas do sujeito com a totalidade do mundo. Já o objeto possuído é aquele que, abstraído das suas funções primárias - a prática, dada pela utilidade, e a social, efetivada pelo compartilhamento - passa a ser justificado, preservado e acariciado pelo sujeito que tem nele um sentido particular, subjetivo, fantasioso e, na maior parte das vezes, oculto. Baudrillard esclarece:

[...] todos os objetos possuídos participam da mesma abstração e remetem uns aos outros na medida em que todos remetem unicamente ao sujeito. Eles se constituem em sistema graças ao qual o sujeito tenta reconstituir um mundo, uma totalidade privada. ${ }^{269}$

Daí também se entende que, para a composição e perenidade dessa abstração apaixonada, o sujeito tenha a necessidade, não de um único objeto, mas de uma variedade deles. Baudrillard explica assim essa necessidade: "só uma organização mais ou menos complexa de objetos que se remetem uns aos outros constitui cada objeto numa abstração

\footnotetext{
${ }^{267}$ BENJAMIN. Desempacotando minha Biblioteca. Um discurso sobre o colecionador. In: Escolhidas II, 2000, p. 228.

${ }^{268}$ BAUDRILLARD. Le système des objets, 1981.

${ }^{269}[\ldots]$ touts les objets possédés participent de la même abstraction et renvoient les uns aux autres dans la mesure où ils ne renvoient qu'au sujet. Ils se constituent alors en système grâce auquel le sujet tente de reconstituer un monde, une totalité privée. Ibidem, p. 14.
} 
suficiente para que ele possa ser recuperado pelo sujeito na abstração vivida que é o sentimento de possessão." ${ }^{270}$ A esse tipo de organização, Baudrillard chama de 'coleção'.

Walter Benjamin, muito antes de Baudrillard, já salientava essa ideia de 'construção de um mundo à parte pelo colecionador' num texto que trata das mudanças ocorridas na França no século XIX, quando o homem deixava a esfera social para investir no universo privado e transformá-lo em um 'refúgio a domicílio'. Benjamin ${ }^{271}$ reconhece no colecionador o verdadeiro ocupante do interior:

\footnotetext{
Ele transfigura os objetos para torná-los coisa sua. [...] O colecionador se imagina não só num mundo longínquo ou passado, mas, ao mesmo tempo, num mundo melhor, onde, sem dúvida, assim como no mundo de todos os dias, os homens não estão desprovidos do que utilizam, mas onde as coisas estão dispensadas da sobrecarga de serem úteis.
}

Sem a obrigatoriedade de seguir à risca a prescrição do objeto funcional, Benjamin ${ }^{272}$ escreve que "a existência do colecionador é uma tensão dialética entre os polos da ordem e da desordem" e que ela é dependente tanto de uma "relação muito misteriosa com a propriedade" quanto de uma relação que, descartada a serventia do objeto, passa a se desenvolver como uma fantasia, e continua assim seu raciocínio:

O maior fascínio do colecionador é encerrar cada peça num círculo mágico onde ela se fixa quando passa por ela a última excitação - a excitação da compra. Tudo o que é lembrado, pensado, conscientizado, torna-se alicerce, moldura, pedestal, fecho de seus pertences. ${ }^{273}$

$\mathrm{Na}$ atração pelos objetos que proporcionam ao sujeito uma abstração apaixonada, Baudrillard reconhece dois tipos de possessores: 1) o colecionador, propriamente dito, que é aquele que se interessa pela possibilidade de constituir uma série a partir de um jogo que pode ser jogado indefinidamente; e 2) o amador, que é aquele que, interessado pelo que há de singular no objeto, reconhece ali uma equivalência ao ser, ou seja, a si mesmo. Se o amador

\footnotetext{
${ }^{270}$ Seule une organisation plus ou moins complexe d'objets renvoyant les uns aux autres constitue chaque objet en une abstraction suffisante pour qu'il puisse être récupéré par le sujet dans l'abstraction vécue qu'est le sentiment de possession. BAUDRILLARD. Le système des objets, 1981, pp. 104-105.

${ }^{271}$ BENJAMIN. Paris, capital do século XIX. In: LIMA (org.). Teoria da Literatura em suas fontes, 2002, pp. 698-699.

272 BENJAMIN. Desempacotando minha Biblioteca. In: Obras Escolhidas II, 2000, p. 228.

${ }^{273}$ Ibidem.
} 
tem um compromisso com a 'quinta-essência qualitativa', indica Baudrillard ${ }^{274}$, o compromisso do colecionador é com a 'manipulação quantitativa'.

Arrefecendo e/ou anulando a utilidade dos objetos (aquilo que qualifica o objeto e o diferencia de uma simples coisa), e transferindo o significado do objeto do campo dos compartilhamentos sociais para o campo da subjetividade, o objeto colecionado é um tipo de coisa. A partir disso, e seguindo as ideias que foram apresentadas no primeiro capítulo desta pesquisa, identifico dois territórios distintos nos quais se dá a posse do objeto: o primeiro território está além do objeto e é onde o amador toma contato com a excepcionalidade da coisa na forma de um 'objeto-sublime', já o segundo território está aquém do objeto e é onde o colecionador toma contato com a coisa na forma de um 'objeto-matéria' que satisfaz o colecionador ao permitir variáveis num exercício infinito de fantasia que se efetiva pela posse.

É evidente que, por aquilo que Benjamin aborda, as relações de coleção que ele priorizava diziam respeito àquelas do amador. Assim, ao tratar dos livros que o encantavam, ele não se refere apenas a autores e títulos, mas salienta também a importância de outros detalhes que valorizariam e particularizariam cada exemplar. É assim que, à frente de uma caixa de livros que ainda falta ser aberta, Benjamin ${ }^{275}$ escreve:

\begin{abstract}
Afloram em mim pensamentos diversos dos que acabei de relatar. Não são pensamentos; são imagens, lembranças. Lembranças das cidades nas quais achei tantas coisas [...]. Lembranças das salas luxuosas [...]; lembranças dos recintos onde esses livros ficavam, da minha toca de estudante [...], do meu quarto em Berna [...] da solidão de Isetwald [...], e por fim do meu quarto de criança [...].
\end{abstract}

E Benjamin ${ }^{276}$ conclui afirmando o que acredita ser o valor da posse: "para o colecionador [...] a posse seja a mais íntima relação que se pode ter com as coisas: não que elas estejam vivas dentro dele; é ele que vive dentro delas". Esse tipo de interação tão intensa entre o objeto e seu proprietário é reforçado por Baudrillard ao apontar que o objeto possuído é o melhor dos espelhos já que "as imagens que ele devolve se sucedem sem se contradizer. E é um espelho perfeito, já que ele não devolve imagens reais, mas as imagens desejadas." 277

Se na maneira mais primitiva de agrupamento de objetos, que seria a simples acumulação, quase não é possível reconhecer algum critério para a sua formação, na

\footnotetext{
${ }^{274}$ BAUDRILLARD. Le système des objets, 1981, pp. 106-107.

${ }^{275}$ BENJAMIN. Desempacotando minha Biblioteca. In: Obras Escolhidas II, 2000, p. 235.

276 Ibidem.

${ }^{277}$ Les images qu'il renvoie ne peuvent que se succéder sans se contredire. Et c'est un miroir parfait, puisqu'il ne renvoie pas les images réelles, mais les images désirées. BAUDRILLARD. Op. cit., p. 108.
} 
acumulação serial de objetos idênticos e/ou semelhantes já é possível reconhecer, pela simples observação, as preferências, limitações e ordenações efetivadas pelo acumulador. Na coleção, com a possibilidade de agrupamento de objetos de todo tipo, a compreensão do que orienta esse exercício é de uma ordem muito mais complexa e dissimulada já que, como escreve Baudrillard: "a coleção é feita de uma sucessão de termos, mas o termo final é a figura do colecionador. Reciprocamente, esta [a figura do colecionador] se constitui como tal ao ser substituída sucessivamente por cada termo da coleção." 278

Mas se o que provoca a coleção é da esfera do privado - as paixões do colecionador existe na série um desejo de socialização que aproxima as coleções da cultura visto que elas reúnem valores significativos para setores específicos da sociedade. Além disso, ao expor o resultado da sua paixão, o colecionador incita um tipo de diálogo que pode lhe trazer novas possibilidades de conquista, além de afastá-lo, ainda que por um breve período, da paranoia de fantasias solitárias. Se existe uma motivação serial interna que é do universo privado do colecionador - no qual a posse está ligada ao prazer -, à medida que a coleção avança e se adensa ela também configura uma motivação serial externa, que é como se entende o jogo proposto pelo colecionador para continuar colecionando. Isto está marcado, segundo Baudrillard, por aquilo que a coleção sinaliza aos outros como 'o que ainda falta':

Tanto quanto por sua complexidade cultural, é pela falta, pelo inacabado que a
coleção se afasta da acumulação pura. A falta é sempre, com efeito, uma
exigência definida, aquela de tal ou tal objeto ausente. E essa exigência, traduzida
como pesquisa, paixão e mensagem aos outros, é suficiente para quebrar o
encantamento mortal da coleção na qual o sujeito se perde em fascinação
pura.

Tendo então a 'falta' como marca principal, a coleção é uma maneira produtiva de sinalizar o vazio como um espaço a ser ocupado ou preenchido, ao invés de ver ali apenas o que foi definitivamente perdido.

\footnotetext{
${ }^{278}$ La collection est faite d'une succession de termes, mais le terme final en est la personne du collectionneur. Réciproquement, celle-ci ne se constitue comme telle qu'en se substituant successivement à chaque terme de la collection. BAUDRILLARD. Le système des objets, 1981, p. 109.

${ }^{279}$ En même temps que par sa complexité culturelle, c'est par le manque, l'inachèvement que la collection s'arrache à l'accumulation pure. Le manque est toujours en effet une exigence définie, celle de tel ou tel objet absent. Et cette exigence, se traduisant comme recherche, passion, message aux autres, suffit à briser l'enchantement mortel de la collection, où le sujet s'abîme en fascination pure. Ibidem, p. 126.
} 


\subsection{O que eles se lembram, ou, o exercício da coleção}

\subsubsection{I remember}

Eu me lembro de "A Coisa". (Ir, p. 14)

A primeira versão do livro I remember de Joe Brainard (1942-1994) foi publicada em 1970. Em 1972 o autor publicou More I remember e em 1973 publicou mais dois volumes da mesma série: More I remember more e I remember Christmas. Em 1975 foi publicado um volume que sintetiza todos os anteriores e ainda contém um material inédito, recebendo o título do primeiro volume: 'I remember' - essa é a versão que continua sendo publicada ainda hoje.

O livro é composto por 1472 micronarrativas que não ultrapassam, cada uma delas, um parágrafo, e começam pelas mesmas palavras: 'I remember' [Eu me lembro] como, por exemplo:

\footnotetext{
Eu me lembro quando a pólio era a pior coisa no mundo. ${ }^{280}$ (Ir, p. 7)

Eu me lembro do dia que John Kennedy foi morto. ${ }^{281}$ (Ir, p. 9)

Eu me lembro de giz. ${ }^{282}$ (Ir, p. 28)
}

Eu me lembro de um remédio líquido vermelho para cortes em um vidrinho marrom que "não vai arder", mas que ardia sempre. ${ }^{283}$ (Ir, p. 100)

O conjunto é configurado por dois tipos de contraintes: uma formal e uma semântica. A contrainte formal que estabelece que todos os parágrafos comecem pelas mesmas palavras é uma forma tradicional chamada de 'anáfora' ${ }^{284}$. Já, a contrainte semântica se refere à maneira como Brainard definiu o conteúdo da obra: cada parágrafo comporta uma lembrança

\footnotetext{
${ }^{280}$ I remember when polio was the worst thing in the world.

${ }^{281}$ I remember the day John Kennedy was shot.

282 I remember chalk.

${ }^{283}$ I remember a red liquid medicine for cuts in a little Brown bottle that "won't Sting” but it always did.

${ }^{284}$ ANÁFORA: é uma figura de repetição que consiste em começar versos, frases ou conjuntos maiores sempre pelas mesmas palavras ou sintagmas. Cf. GORP et al.. Dictionnaire des termes littéraires, 2005, p. 34.
} 
avulsa, pessoal ou não, que é sem explicação, encadeamento, cronologia, interpretação e argumentação.

Essas lembranças trazem descrições, impressões, desejos e posicionamentos que tanto podem ser pessoais como podem se referir a manias, modas e/ou ideias que fazem e/ou faziam parte da da vida de um grupo maior de indivíduos. Há textos curtos, compostos por uma única frase e poucas palavras como, por exemplo: "Eu me lembro de beliches." 285 (Ir, p. 27), como também há textos mais longos compostos de várias frases, como:

Eu me lembro quando tudo estava coberto de neve, lá fora, logo cedo de manhã: uma surpresa realmente clara. Só nevava duas vezes por ano em Tulsa e, como eu me lembro agora, geralmente durante a noite. Assim, eu me lembro mais da "neve" do que de "nevar". ${ }^{286}$ (Ir, p. 117)

Ron Padgett, escritor e amigo de infância de Brainard, escreve no posfácio de $I$ remember que Brainard, no momento em que começou a escrever suas lembranças, estava muito entusiasmado com a poesia de Gertrude Stein ${ }^{287}$. Sobre o período de gestação de $I$ remember, Padgett cita uma carta de Brainard a [Anne] Waldman:

\begin{abstract}
Ainda estou lendo [Stein] [...] e ainda a acho muito difícil e pensava como seria bom ouvir Gertrude Stein em voz alta... Estou trabalhando esses dias numa peça que continuo escrevendo chamada I Remember. Eu me sinto como Deus escrevendo a bíblia. Quero dizer, me sinto como se não estivesse realmente escrevendo isso, mas é por minha causa que isso está sendo escrito. Também sinto que ela é sobre todo mundo da mesma maneira que é sobre mim. E isso me agrada. Quero dizer, me sinto como se fosse todo mundo. E esse é um sentimento bom. Isso não durará. Mas estou aproveitando enquanto posso. ${ }^{288}$
\end{abstract}

\footnotetext{
${ }^{285}$ I remember bunk beds.
}

${ }^{286}$ I remember when everything is covered with snow, out the window, first thing in the morning: a really clear surprise. It only snowed about twice a year in Tulsa and, as I remember now, usually during the night. So, I remember "snow" more than I remember "snowing".

${ }^{287}$ Gertrude Stein (1874-1946). Escritora e poeta americana que viveu ativamente a vanguarda francesa nas três primeiras décadas do século XX, e que produziu uma obra poética marcada pela repetição de palavras, longas listas e uma forma compulsiva de lidar com a linguagem até esgarçá-la, dificultando a tentativa de compor um discurso nítido e completo, valorizando mais a sonoridade das palavras do que exatamente o significado delas.

${ }^{288}$ I am still reading [Stein] [...] and I still find her very difficult and I was thinking how great it would be to hear Gertrude Stein out loud... I am way, way up these days over a piece I am still writing called I Remember. I feel very much like God writing the bible. I mean, I feel like I am not really writing it but that it is because of me that is being written. I also feel that it is about everybody else as much as it is about me. And that pleases me. I mean, I feel like I am everybody. And it's a nice feeling. It won't last. But I am enjoying it while I can. BRAINARD apud PADGETT. Afterword. In: BRAINARD. I remember, 2006, p. 171. 
Se para o trabalho com a linguagem, Brainard tomava como referência alguns aspectos da obra de Stein, era a obra de Andy Warhol, afirma Padgett, que indicava para Brainard a maneira mais contemporânea de lidar com a repetição e ainda manter um distanciamento do trabalho.

Ainda que de uma concepção muito simples, a escrita de I remember não ocorria de forma simples, direta e sequencial para Brainard, e precisou ser refeita muitas vezes até satisfazer seu autor (os manuscritos completos ultrapassavam seiscentas páginas ${ }^{289}$ ). Para a edição que englobaria todas as anteriores, ele não só efetuou um exercício de edição, como acrescentou novas lembranças e reescreveu vários trechos que já haviam sido publicados anteriormente. Mesmo que o texto pareça ser o resultado de uma escrita automática, o artista trabalhou sobre cada lembrança, aumentando e diminuindo a fragmentação do discurso final. Para Padgett ${ }^{290}$, a opção de trabalhar individualmente com cada lembrança permitia a seu autor uma grande liberdade para pular de uma micronarrativa para outra, avançando e retroagindo no tempo e no espaço por meio de relações inusitadas.

Existe ainda nessas lembranças um grande estranhamento que surge com a fórmula adotada para a escrita: como não há hierarquias, cronologias ou mapeamentos das lembranças, tanto o que era circunstancial, como o que era o rotineiro, ou o que pertencia à intimidade, ou ainda o que era obsessivo e patológico, tudo tem o mesmo estatuto e isso é perturbador, pois apaga nuances e impede o leitor de avaliar consequências e repercussões, bem como de imaginar antecedentes ou ainda de estabelecer correlações. Nos vazios entre as lembranças da página 134 (fig. 14), por exemplo, tanto se pode pensar tudo como não se está autorizado a pensar nada:

Eu me lembro de visões horríveis daquela ilha para onde os leprosos eram enviados.

Eu me lembro da "coisa verde" dentro da minha primeira lagosta.

Eu me lembro (argh!) de sapatos brancos de enfermeira.

Eu me lembro de tentar visualizar "as viagens" da merda, depois que você dá a descarga.

Eu me lembro, quando alguém está ao seu lado numa latrina pública, o tempo que leva para você dar a "partida".

Eu me lembro de Halloween e do problema anual entre usar uma máscara ou ver. (Óculos).

\footnotetext{
${ }^{289}$ PADGETT. Afterword. In: BRAINARD, I remember, 2006, p. 173.

${ }^{290}$ Ibidem, p. 172.
} 
Eu me lembro de óculos sobre máscaras de cetim.

Eu me lembro de vizinhos que não cuidam dos seus gramados.

Eu me lembro do dia após Halloween, falar sobre portas de carro ensaboadas, e de móveis de jardim aparecendo em varandas desconhecidas.

Eu me lembro de uma garota que podia torcer completamente seu polegar para trás. E de um garoto que podia abanar uma orelha por vez.

\section{Definida}

restrição que estruturava

o texto como uma

coleção de fragmentos de memória (a contrainte), o artista podia recolher tudo o que passasse por sua cabeça sem receio de ter que se explicar/justificar depois, afinal de contas ele colecionava lembranças e não fatos, estando assim livre para se lembrar do que bem quisesse, na ordem, na quantidade e na extensão que ele considerasse relevante. Finalmente, o artista estava livre do que o atrapalhava nas colagens e que o levava a começar tantos trabalhos e a terminar poucos deles: ele não precisava agora

\section{4}

I remember horrible visions of that island where lepers were sent.

I remember "the green stuff" inside my first lobster.

I remember (ugh) white nurse shoes.

I remember trying to visualize "the travels" of shit, after you flush the toilet.

I remember, when someone is standing next to you in a public latrine, how long it can seem before you get "started."

I remember Halloween and the annual problem of whether to wear a mask or to see. (Glasses.)

I remember glasses on top of satin eye masks.

I remember next-door neighbors who don't keep up their lawns.

I remember, the day after Halloween, talk about car door windows getting soaped, and of lawn furniture appearing on unfamiliar porches.

I remember a girl who could bend her thumb all the way back. And a boy who could wiggle one ear at a time.

Figura 14 - Joe Brainard. I remember, 2006, p. 134. 
se limitar a um grupo de objetos que definiam o ponto de partida de um caminho que ele não sabia onde o conduziria.

Com I remember, Brainard alcançou uma grande liberdade em relação à maneira como trabalhava o fragmento - agora ele tinha um material que lhe permitia circular com mais liberdade do que antes. Uma liberdade que também seria do leitor, já que este poderia circular pelo seu livro como bem entendesse: sequencialmente, aos pulos, de trás para frente. Agora, qualquer que fosse o trajeto da leitura, sempre haveria a possibilidade da surpresa: é assim que, no meio de tantas lembranças ingênuas, espirituosas, tocantes, é possível encontrar outras de teor sexual, escatológico, de viés racista ou religioso.

Se no início do trabalho com as lembranças o artista parecia simular seu exercício de perambulação pela cidade de Nova York, agora, depois de trabalhar individualmente com cada um dos fragmentos para compor um todo baseado em uma única contrainte, o artista se voltava de outro modo para o campo plástico. Ele continuaria a lidar com os pedaços de real, mas ao invés de trabalhar por adição de elementos, ele passaria a recorrer ao desenho e à pintura para compor um novo campo uniformizador onde ele definiria um jogo de figuras com uma liberdade semelhante ao que fizera em I remember.

É assim que eu encontro, com surpresa, um trabalho de Brainard do início dos anos setenta (fig. 15), no qual o artista faz uso de uma técnica muito refinada de desenho e pintura que uniformiza e compõe um espaço de diálogo entre objetos tão distintos que parecem ter se encontrado por acaso. No diálogo entre eles surge um murmurinho que afirma uma presença própria do que já foi dito do ruído de fundo, do infraordinário, e que Brainard compõe em imagem o que Perec indicava em Approches de quoi? (Cf. tradução, item 2.1.2.1.): mexer nos bolsos, conversar com as colherinhas e não ter medo (ou vergonha) do que pode encontrar ali. 


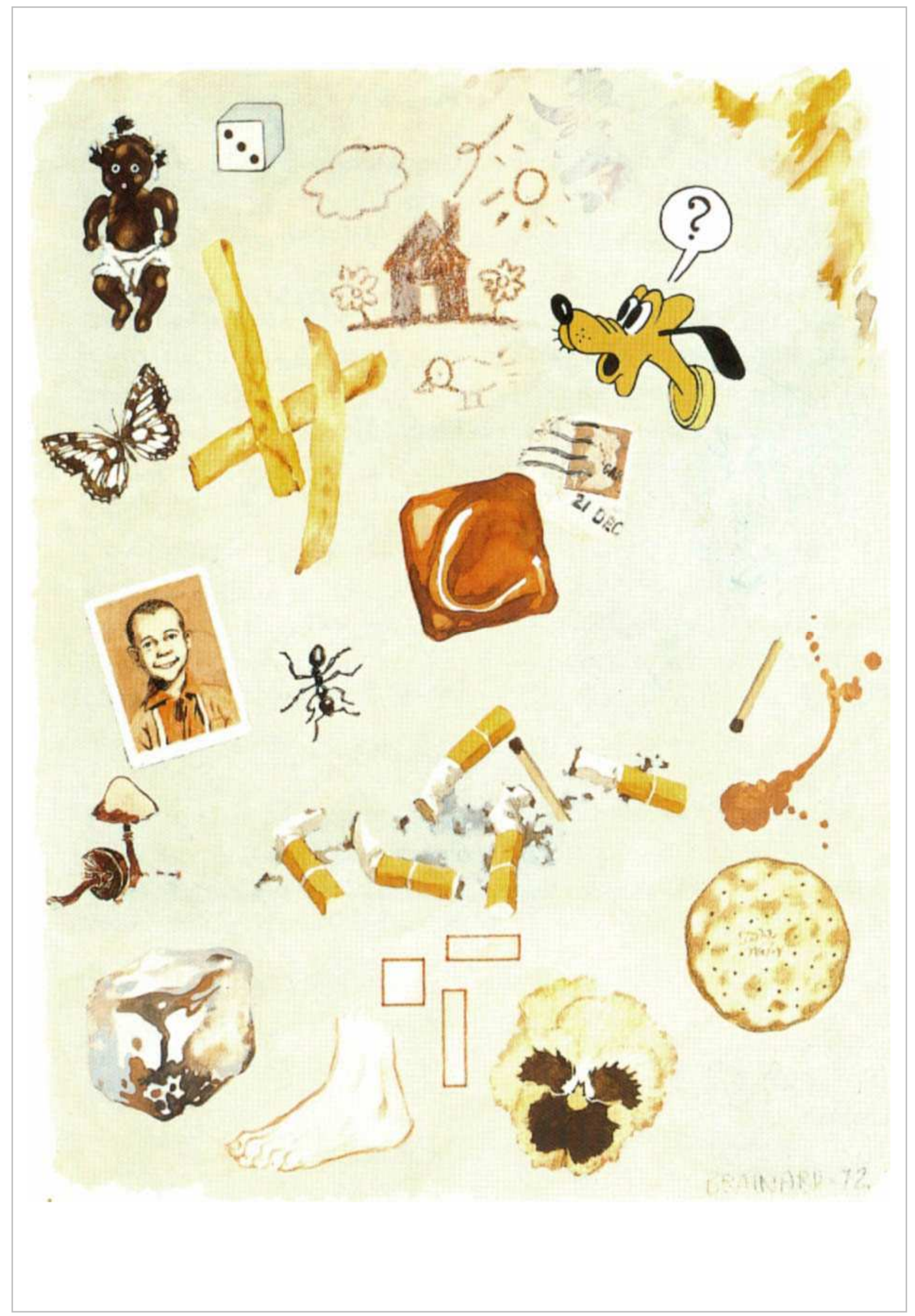

Figura 15 - Joe Brainard, Untitled (Various images) [Sem título (Várias imagens)], (1972). Guache, lápis e tinta sobre papel, $35,5 \times 27,94 \mathrm{~cm}$. 


\title{
2.5.2. Je me souviens
}

\author{
[Lembrança $\left.\mathrm{n}^{\circ}\right] 185$ \\ Eu me lembro dos buracos nos bilhetes do metrô. ${ }^{291}$ (Jms, p. 52)
}

Para Lejeune, Je me souviens - Les choses communes I [Eu me lembro - As coisas comuns I] é "uma sessão de hipnose coletiva [...]. A pequena madalena para todos..." ${ }^{292}$. Publicado em 1978, esse livro tem 480 parágrafos numerados sequencialmente, contendo cada um deles uma lembrança que se inicia sempre da mesma forma: Je me souviens [Eu me lembro]. A ideia de compor um livro por meio de uma sequência de pequenos blocos de texto que começam sempre da mesma maneira e que contém lembranças avulsas foi tomada de $I$ remember de Joe Brainard, o que já é revelado ao leitor na página que antecede o início do texto propriamente dito.

A primeira vez que Perec ouviu falar de I remember foi em 1970 - ano de lançamento do livro nos Estados Unidos - através de um novo amigo: o escritor americano Harry Mathews, que ele conhecera poucos meses antes ${ }^{293}$. Mesmo sem ter tido ainda qualquer contato direto com o livro de Brainard, Perec gostou tanto do procedimento adotado pelo americano que, segundo Bellos ${ }^{294}$, ele começou quase que imediatamente a jogar Je me souviens com amigos, estabelecendo como regras básicas que todas as lembranças deveriam ser comuns a outras pessoas e que o objeto das lembranças não poderia mais existir.

Se no livro de Brainard existem lembranças que tratam tanto da vida pessoal do autor como de aspectos diversos da cultura e da vida em sociedade - sendo então uma forma inovadora de apresentar um conteúdo autobiográfico -, no livro escrito por Perec é mais pertinente que se fale de uma 'biografia coletiva de uma época', já que suas lembranças dizem respeito àquilo que foi compartilhado por contemporâneos e conterrâneos seus. Se Perec trabalhou para apagar os sinais de uma pessoalidade nas lembranças selecionadas, seu esforço foi no sentido de descobrir nelas o que era compartilhável:

\footnotetext{
291185 / Je me souviens des trous dans les tickets de métro.

${ }^{292}$ Une séance d'hypnose collective. [...] La petite Madeleine pour tous... LEJEUNE. La mémoire et l'oblique, 1991, p. 236.

${ }^{293}$ Harry Mathews será um amigo importante para Perec e o livro Je me souviens é dedicado a ele. Em 1970, ano de publicação de I remember, de Joe Brainard, Mathews também havia publicado nos Estados Unidos um livro de poesias chamado The ring. Curiosamente, o artista responsável pela capa do livro havia sido o próprio Brainard. Em 2002 o livro de Brainard é lançado na França - I remember (Je me souviens), Éditions Actes Sud, Collection Babel - com tradução de Marie Chaix, casada atualmente com Harry Mathews.

${ }^{294}$ BELLOS. Georges Perec, 1994, p. 482.
} 
Eu acredito que tentei em Je me souviens aplicar essa rememoração sistemática a toda minha geração: escrever um fragmento de autobiografia que poderia ser aquela de todos os parisienses da minha idade. Importa pouco que essas lembranças sejam pessoais (únicas) ou gerais (coletivas), [...] isso funciona como uma grade onde cada um pode vir decifrar um fragmento de sua própria história. ${ }^{295}$

Enquanto o livro de Brainard apresenta 1472 lembranças, o livro de Perec - como foi dito inicialmente - possui apenas 480. O livro de Perec repete tanto a contrainte formal do livro de Brainard - a anáfora -, quanto as contraintes semânticas, acrescentando outras: a exclusão de lembranças pessoais e de grandes eventos, e a contrainte mais importante que seleciona apenas as lembranças desimportantes que pudessem ter sido compartilhadas, pertencendo então às coisas comuns. Ainda que nos dois livros não seja possível identificar qualquer tipo de distribuição das lembranças (nem temática, nem cronológica, nem geográfica etc.), o texto de Brainard nos fornece um número maior de informações no interior de cada lembrança, tornando possível a composição de uma micronarrativa - o que não acontece no livro de Perec. Em compensação, existe no final de Je me souviens um índice de 23 páginas que identifica temas, nomes, denominações, localidades, no interior das lembranças citadas no livro, com a possibilidade de se chegar a uma mesma lembrança através de várias entradas do índice. Esse tipo de procedimento, ainda que bastante técnico e frio, principalmente por se tratar de um livro de lembranças, permite ao leitor consultar o livro por interesses particulares já que cada número designa um lugar específico para a lembrança assinalada.

O caderno onde Perec colecionou suas lembranças é um caderno grande, com pauta como os usados para anotações comerciais -, traz na capa a palavra 'Choses' e na página de título: “1973. Choses communes. Espèces d'espaces” ${ }^{296}$. As lembranças começaram a ser anotadas em 21 de janeiro de 1973, foram escritas a mão ou coladas em pequenos pedaços de papel, numeradas sequencialmente e - de maneira diversa ao que ocorre no livro - trazem a data em que foram incluídas no caderno ${ }^{297}$. No caderno estão registradas as lembranças que

${ }^{295}$ Je pense que j'ai essayé dans Je me souviens d'appliquer cette remémoration systématique à toute ma génération: écrire un fragment d'autobiographie qui pourrait être celle de tous les Parisiens de mon âge. Il importe peu que ces souvenirs soient personnels (uniques) ou généraux (collectifs), [...] cela fonctionne comme une grille où chacun peut venir déchiffrer un fragment de sa propre histoire. LE SIDANER. Entretien avec Georges Perec. (1979). In: L’Arc, 2005, p. 30.

296 Nesse caderno estão os primeiros esboços do que seria Espèces d'espaces - publicado no ano seguinte (1974) -, e as primeiras listas de Notes de chevet (livro que Perec pensava escrever a partir da obra homônima de Sei Shônagon - que tratarei no capítulo seguinte -, mas que nunca realizou). Cf. LEJEUNE. La mémoire et l'oblique, 1991, p. 242.

${ }^{297}$ Cf. NEEFS; HARTYE. Georges Perec. Images, 1993, pp. 148-149. 
vão até o dia 16 de maio de 1977 - o que corresponde à lembrança de no 348 -, as outras 160 lembranças, segundo Lejeune ${ }^{298}$, devem ter sido anotadas em folhas avulsas e se perderam. $\mathrm{O}$ texto anotado é exatamente o mesmo do texto publicado.

Cada uma das 480 lembranças perequianas se apresenta como um fato/objeto isolado, tal como uma 'coisa' que marca um lugar e que responde unicamente a Perec e a outros da sua geração de parisienses (não existem notas explicativas ou qualquer tipo de complementação). Ainda que o próprio Perec ${ }^{299}$ considerasse seu texto como um 'trampolim para a ficção', uma espécie de empatia entre as pessoas, um jogo para se jogar com muitas pessoas, quanto mais nos afastamos do que foi resgatado pelas lembranças de Perec, mais incompreensível se torna o que ele nos indica e esse jogo agora só é possível como um 'jogo derivado’ ou um 'jogo em paralelo'. Como o leitor do século XXI (e outros que deverão segui-lo) pode lidar com tantos nomes de lugares, marcas, eventos e expressões que designam agora o que não se sabe o quê? Foi por entender que o conteúdo do livro de Perec guarda muitas informações reveladoras da vida em sociedade e da cultura francesa do pós-guerra e que agora se perderam, é que Roland Brasseur escreveu Je me souviens encore mieux de Je me souviens. Notes pour Je me souviens de Georges Perec à l'usage des générations oublieuses et de celles qui n'ont jamais su [Eu me lembro ainda melhor de Eu me lembro. Notas para Eu me lembro de Georges Perec para o uso das gerações que se esquecem e aquelas que nunca souberam]. Nesse livro, de quase 400 páginas, o autor busca trazer maiores detalhes sobre o que designavam todos os nomes citados quando eles ainda tinham alguma serventia - o que permitiria pensá-los como 'objetos'. Agora, deslocados de uma narrativa que lhes poderia dar algum sentido, esses nomes se parecem mais com coisas que têm valor apenas para seus colecionadores.

Como exemplo do estranhamento contido nessas lembranças, apresento o que encontro na página 55 (fig. 16):

[Lembrança $\left.\mathrm{n}^{\circ}\right] 196$

Eu me lembro que Marina Vlady é a irmã de Odile Versois (e que elas são as filhas do pintor Poliakoff).

[Lembrança $\left.\mathrm{n}^{\circ}\right] 197$

Eu me lembro dos filmes com o cachorro Rin-Tin-Tin, e também daqueles com Shirley Temple, e também das poesias de Minou Drouet.

\footnotetext{
${ }^{298}$ LEJEUNE. La mémoire et l'oblique, 1991, p. 244.

${ }^{299}$ PEREC. The Doing of Fiction. (1981). In: Entretiens et Conférences, 2003b, p. 259.
} 
[Lembrança $\left.\mathrm{n}^{\circ}\right] 198$

Eu me lembro do campeão de rugby da XIII Puig-Aubert, chamado "Pipeta".

[Lembrança $\left.\mathrm{n}^{\circ}\right] 199$

Eu me lembro do escândalo dos "Balés rosas" no qual foi comprometido o Presidente da Câmara, André Le Troquer.

Brasseur não
buscou estabelecer uma
relação direta entre os
dados contidos nas lembranças e a vida e/ou obra de Perec. Às vezes, isso é possível, outras não. Assim, somos informados que, entre outras observações, na lembrança $\mathrm{n}^{\mathrm{o}} 196$, Marina e Odile eram realmente irmãs e atrizes, filhas de Vladimir de Poliakoff, um emigrado russo que teve várias profissões e não tinha qualquer relação com o pintor Serge Poliakoff (um dos vários enganos que aparecem em $\mathrm{Je}$ me souviens). Na lembrança $\mathrm{n}^{\circ}$ 197, sabe-se pela simples leitura que os personagens citados são dois 'atores' e um escritor. Brasseur não faz qualquer conjectura sobre o que justificaria a reunião desses três personagens - duas crianças e um cachorro - numa mesma lembrança. Uma coisa comum aos
Je me souviens que Marina Vlady est la sœur d'Odile Versois (et qu'elles sont les filles du peintre Poliakoff).

\section{7}

Je me souviens des films avec le chien Rin-TinTin, et aussi de ceux avec Shirley Temple, et aussi des poésies de Minou Drouet.

\section{I98}

Je me souviens du champion de rugby à XIII Puig-Aubert, surnommé "Pipette ».

\section{9}

Je me souviens du scandale des "Ballets roses " dans lequel fut compromis le Président de la Chambre, André Le Troquer.

Figura 16 - Georges Perec. Je me souviens (Les choses communes I), 2004a, p. 55. 
três foi o fato de terem trabalhado bastante, feito muito sucesso e recebido muito dinheiro, estando ainda sob a tutela de alguém. Na lembrança de $\mathrm{n}^{\circ} 198$, o fato curioso parece ser a maneira como o jogador era chamado: Pipette [Pipeta]. Isso, explica Brasseur, se devia ao fato dele fumar bastante. Já, a lembrança de $n^{\circ} 199$ trata de um escândalo de desvio de menores envolvendo o Presidente da Câmara que acabou sendo acusado de atentado ao pudor em 1959.

O livro de Perec, como se viu, indica muitas coisas e revela muito pouco. Mesmo assim, nada ali chega a ser uma surpresa para o leitor visto que ele recebe esclarecimentos importantes sobre o conteúdo do livro em dois momentos: no posfácio e na quarta capa. Pelo posfácio o leitor é informado que as lembranças do livro começaram a ser anotadas em janeiro de 1973 e que só terminaram em junho de 1977 e que as lembranças se referem ao período entre 1946 e 1961, quando Perec tinha entre dez e vinte e cinco anos. Ele também reconhece que existem ali alguns erros, mas que isso não chega a incomodá-1o ${ }^{300}$.

Estão na quarta capa, no texto que Perec apresenta a obra, as informações que garantem o seu interesse:

Estes “eu me lembro" não se tratam exatamente de lembranças e, sobretudo de lembranças pessoais, mas de pequenos pedaços de cotidiano, de coisas que, tal ou tal ano, todas as pessoas de uma mesma idade viram, viveram, compartilharam, e que em seguida desapareceram ou foram esquecidas; elas não valiam a pena ser memorizadas, ela [sic] não mereciam fazer parte da História [...].

Acontece, no entanto, que elas voltam alguns anos mais tarde, intactas e minúsculas, por acaso ou porque as procuramos [...]; um gesto, ou alguma coisa ainda mais sutil, de inessencial, totalmente banal, miraculosamente arrancado da sua insignificância, encontrado por um instante, suscitando por alguns segundos uma impalpável pequena nostalgia. ${ }^{301}(\mathrm{Jms})$

${ }^{300}$ Ainda no posfácio, Perec justifica que o período dessas lembranças corresponde para ele a um período do domínio do mito (eu entendo isso como um período de muitas 'fantasias') e que, em função disso, várias das suas lembranças seriam 'objetivamente falsas' - ele mesmo reconhece e aponta um erro numa de suas lembranças. Isso amplifica a incerteza e confere um tom irônico ao livro - jogada tipicamente perequiana. Um exemplo desse jogo-duplo (a favor e contra o leitor) está na inclusão de um sinal de interrogação entre parênteses no meio da lembrança $n^{\circ}$ 294: Je me souviens que le personnage central de l'Étranger se nomme Antoine (?) Meursault: il a été souvent remarqué que l'on ne se souvient pas de son nom. [Eu me lembro que o personagem central de $O$ Estrangeiro se chama Antoine (?) Meursault: foi muito observado que nós raramente nos lembramos de seu nome.] No livro de Camus, o personagem se chama simplesmente 'Meursault'. Brasseur conseguiu identificar no livro 80 erros e/ou esquecimentos e/ou enganos. Cf. BRASSEUR. J'me souviens plus très bien. Les erreurs de Perec. In: de Je me souviens, 2003, pp. 323-326. . Je me souviens encore mieux

${ }^{301}$ Ces "je me souviens" ne sont pas exactement des souvenirs, et surtout pas des souvenirs personnels, mais des petits morceaux de quotidien, des choses que, telle ou telle année, tous les gens d'un même âge ont vues, ont vécues, ont partagées, et qui ensuite ont disparu, ont été oubliées; elles ne valaient pas la peine d'être mémorisées, elle [sic] ne méritaient pas de faire partie de l'Histoire [...]. I Il arrive pourtant qu'elles reviennent, quelques années plus tard, intactes et minuscules, par hasard ou parce qu'on les a cherchées 
Mesmo que o livro de Perec pareça uma acumulação indiferenciada de banalidades, na leitura de Lejeune se passa exatamente o oposto: Je me souviens seria um trabalho muito organizado por aquilo que ele chama de "criação negativa" onde o autor, se recusando a escrever tudo o que passava por sua cabeça, se punha em estado de concentração a espera do melhor momento para agir - situação semelhante à do pescador com sua vara de pescar que, visto de longe, parece não fazer nada num lugar onde não acontece nada. Também por essa imagem seria possível reconhecer o infra-ordinário: "aquilo que acontece quando não acontece nada" ${ }^{302}$, justificando assim o subtítulo do livro que deveria compor uma série que nunca se realizou: Les choses communes $I$ [As coisas comuns I] ${ }^{303}$.

Sobre o desimportante das coisas comuns, Perec afirma:

Pensamos que nos lembramos de fatos muito importantes, mas, certamente, temos a experiência de fatos que, ainda que não tenham qualquer importância, nos dizem muito mais respeito. Talvez o mais importante seja a tomada de consciência do cotidiano. ${ }^{304}$

Sobre a realidade, a lembrança e a escrita, Perec esclarece:

Quando eu tento descrevê-lo [o cotidiano], eu tento desde o início descrever isso que eu vejo, quer dizer, a realidade. E quando eu tento me lembrar, eu tento me lembrar da realidade; mas [...] progressivamente, a realidade se transmite apenas por meio da linguagem, por meio da escritura. Isso que envolve a realidade por meio da linguagem é da ordem da ficção, e é por meio da ficção e da linguagem que as pessoas se comunicam. ${ }^{305}$

Sobre o não-dito - isso que Blanchot reconhece como o traço essencial do cotidiano: 'o que não se deixa apanhar' -, ele também está presente no livro de Perec através dos longos espaços em branco que separam cada uma das lembranças e que só são apreendidos quando se olha para a página impressa (fig. 16). Esses espaços são a própria representação do que

[...]; un geste, ou quelque chose d'encore plus mince, d'inessentiel, de tout à fait banal, miraculeusement arraché à son insignifiance, retrouvé pour un instant, suscitant pendant quelques secondes une impalpable petite nostalgie.

${ }^{302}$ PEREC. Ce qu'il se passe quand il ne se passe rien. (1978). In: Entretiens et Conférences, 2003a, p. 214.

${ }^{303}$ Tratarei dos outros livros que fariam parte da série no próximo capítulo.

${ }^{304}$ On pense que l'on se souvient de faits très importants, mais, bien sûr, on a l'expérience de faits qui n'ont aucune importance mais qui sont beaucoup plus parlants pour nous. Le plus important, c'est peut-être cette prise de conscience du quotidien. PEREC. The Doing of Fiction. (1981). In: Conférences, 2003b, p. 259.

${ }^{305}$ Quand j'essaie de le [quotidien] décrire, j'essaie d'abord de décrire ce que je vois, c'est-à-dire la réalité. Et quand j'essaie de me souvenir, j'essaie de me souvenir de la réalité; mais [...] progressivement, la réalité ne se transmet qu'à travers le langage, qu'à travers l'écriture. Ce qui entoure la réalité à travers le langage est de l'ordre de la fiction, et c'est à travers la fiction et le langage que les gens communiquent. Ibidem. 
Lejeune chamou de 'o trabalho negativo da escrita'. 'Se em Je me souviens o texto é curto, a leitura é longa', afirma Lejeune ${ }^{306}$, e não adianta o leitor querer se apressar, esse não é um livro de $(\mathrm{H})$ istórias, nem de acontecimentos. Como exercício infinito daquilo que ainda está para ser lembrado - e que eu reconheço nesta obra como a marca essencial do colecionar -, o autor indica a continuação do jogo coletivo da memória de duas maneiras: primeiro, pela indicação de continuação do exercício de lembrar:

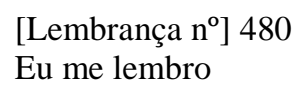

e segundo, através da nota logo após o índice:

A pedido do autor, o editor deixou na sequência desta obra, algumas páginas brancas sobre as quais o leitor poderá notar seus "Eu me lembro" que a leitura destes, nós o esperamos, terão suscitado. ${ }^{308}$ (Jms, p. 147)

Só depois de ler e reler Je me souviens, é que me dei conta que seu livro nos propõe exatamente o contrário do que anuncia: o livro não trata de lembranças, mas de esquecimentos. O esforço de Perec em dar visibilidade ao ínfimo, ao desimportante, ao banal, através da marca e do traço, fez com que tivéssemos contato com essas lembranças - que estão ali como coisas -, mas que vão sendo esquecidas na medida em que avançamos em nossa leitura. Está aí a fórmula utilizada por Perec para dar a ver o desimportante, impedindo que essas lembranças adquirissem o valor oposto: retiradas do banal pelo autor, elas não assumem o valor de acontecimento/fato/conhecimento extraordinário e voltam ao banal pela ação do leitor que, terminada a leitura, terá que se esforçar muito para se lembrar de algum fragmento do livro.

Lejeune ${ }^{309}$ nota que Perec, que começa Je me souviens por uma confissão de imitação do livro de Brainard, conclui seu livro conclamando seus leitores a fazer o mesmo, agora com seu livro. Desse modo, também será possível desemboscar outras coisas comuns dos invólucros onde estão emboscadas e silenciosas, permitindo que, vindo à luz, possam depois voltar para onde estavam por um acordo gentil com o esquecimento.

\footnotetext{
${ }^{306}$ LEJEUNE. La mémoire et l'oblique, 1991, p. 246.

307 [Souvenir $\mathrm{n}^{\circ}$ ] 480 / Je me souviens / (à suivre...)

${ }^{308}$ À la demande de l'auteur, l'éditeur a laissé à la suite de cet ouvrage quelques pages blanches sur lesquelles le lecteur pourra noter les "Je me souviens” que la lecture de ceux-ci aura, espérons-le, suscités.

${ }^{309}$ LEJEUNE. Op. cit., p. 236.
} 


\title{
2.6. O que Perec não esquece
}

\begin{abstract}
O que significam as coisas, o que significa o mundo? Toda a literatura é essa pergunta, mas é necessário acrescentar, pois é isso que faz sua especialidade: é essa pergunta menos sua resposta. Nenhuma literatura do mundo nunca respondeu à pergunta que ela fazia, e é exatamente essa indecisão que sempre a constituiu em literatura $[\ldots] .^{310}$
\end{abstract}

Roland Barthes

O editorial Approches de quoi? é um marco importante na obra de Perec por aquilo que designa do campo de questionamentos desse autor, e é difícil encontrar autores que exponham com tamanha pertinência as perguntas que projeta para sua obra, e consequentemente para seus leitores, como Perec gostava de reforçar quando provocado:

Eu estou completamente do lado das perguntas e não das respostas. É o que diz Barthes: "A verdadeira responsabilidade do escritor, não é de dar respostas, mas de fazer perguntas." Eu penso que tenho uma atitude que é questionadora perante os elementos e que não há verdade da qual eu seja detentor. ${ }^{311}$

São também os questionamentos de sua obra que me fazem perguntar: haveria um momento preciso ou um motivo particular que teriam indicado ao autor o interesse pelo desimportante? No campo intelectual é fácil lembrar a proximidade de Perec com outros autores contemporâneos que produziram obras de repercussão no campo dos estudos do cotidiano como, por exemplo: Henri Lefebvre (autor de Critique de la vie quotidienne), Edgar Morin (co-diretor, junto de Jean Rouch, do filme Chronique d'un été), Roland Barthes (autor de Mythologies), além de Paul Virilio e Jean Duvignaud, colegas seus em Cause commune.

Paul Virilio encontra um estímulo para esse interesse de Perec naquilo que marcou sua infância, semelhante a do próprio Virilio, que também era criança durante a guerra. Para essas crianças, indica Virilio, aprender a reconhecer e a entender o significado do insignificante era uma questão de sobrevivência e essa é uma lição que não se esquece:

${ }^{310}$ Qu'est-ce que les choses signifient, qu'est-ce que le monde signifie? Toute littérature est cette question, mais il faut tout de suite ajouter, car c'est ce qui fait sa spécialité: c'est cette question moins sa réponse. Aucune littérature au monde n'a jamais répondu à la question qu'elle posait, et c'est ce suspens même qui l'a toujours constituée en littérature [...]. BARTHES. Le point sur Robbe-Grillet? (1963). In: Euvres complètes, 2002 b, p. 456.

${ }^{311}$ Moi, je suis complètement du côté des questions et non de celui des réponses. C'est ce que dit Barthes: "La véritable responsabilité de l'écrivain, ce n'est pas de donner des réponses mais de poser des questions 39." Moi, je pense que j'ai une attitude qui est questionnante vis-à-vis des éléments et qu'il n'y a pas de vérité dont je serais le détenteur. SIMONY. Entretien avec Gabriel Simony. (1981). In: PEREC. Entretiens et conférences, 2003b, p. 221. 
Perec e eu éramos crianças da guerra. Crianças não tomam parte em guerras, mas elas olham - elas são voyeurs, elas são curiosas. Assim, Perec e eu fomos voyeurs da guerra. Para nós a guerra era um espetáculo enorme. Ele se refugiou nos Alpes, na região de Vercors, e eu me refugiei em Nantes. [...] Assim, nossa relação com a guerra era de pura encenação: nós assistíamos o mundo ruir. Por essa razão, aprendemos como olhar. Isso está certamente na raiz do nosso interesse pelo infraordinário - aqueles sinais e sintomas que ele e eu aprendemos a interpretar com o objetivo de sobreviver. Em minha opinião, esse é um elemento muito importante no trabalho de Perec, e também no meu. Se eu estou interessado em velocidade e guerra [...] é porque eu fui treinado a ler sinais quando não havia tempo suficiente para analisá-los. A pessoa tinha que ser muito rápida e sensível à percepção, a pessoa tinha que entender tudo num piscar de olhos. ${ }^{312}$

${ }^{312}$ Perec and I were children of the war. Children do not take part in wars, but they do look - they are voyeurs, they are bystanders. So Perec and I were voyeurs of war. For us war was an enormous spectacle. He took refuge in the Alps, in the region of Vercors, and I took refuge in Nantes. [...] So our relation to war was one of pure spectacle: we watched the world collapse. Therefore, we learnt how to look. This is certainly at the root of our interest in the infra-ordinary - those signs and symptoms that he and I learnt to interpret in order to survive. I my opinion this is a very important element of Perec's work, and also of my own. If I am interested in speed and in war [...] it is perhaps because I was trained to read signs when there was not enough time to analyze them. One had to be fast and perceptive, one had to understand everything in the blink of an eye. WALKER. Paul Virilio on Georges Perec. In: AA Files 45/46, 2001, p. 18. 


\section{0 arquivo, ou, o que está por ser feito}

\subsection{Escrever para viver, ou, viver para escrever?}

No início, tudo parece simples: eu queria escrever, e eu escrevi. [...] eu não faço nada além de escrever (senão ganhar o tempo de escrever), eu não sei fazer nada além disso, eu não quis aprender outra coisa... Eu escrevo para viver e vivo para escrever, e eu não estive longe de imaginar que a escrita e a vida poderiam se confundir completamente $\left[\ldots .\right.$. . $^{313}$

Georges Perec

Após dois anos de trabalho com o OuLiPo, Perec iniciou em 1969 uma experiência que buscava tirar o exercício da contrainte do âmbito da elaboração formal do texto literário, ou seja, do espaço da folha de papel, para utilizá-la na estruturação de uma nova relação do autor com o espaço das vivências concretas: o real.

O projeto era ambicioso e definia para o autor uma rotina de escrita que deveria durar doze anos. Antes de completar a metade do prazo inicialmente estabelecido para esse projeto, o autor já havia desistido de continuar e, ainda hoje, a maior parte do que foi produzido para esse projeto continua inédito. Qual a importância em tratar de um projeto malogrado sobre o qual muitos falam e apenas um pesquisador teve acesso?

Este capítulo é sobre aproximações e possibilidades, como é próprio do exercício com arquivos, documentos e índices. Se pelo exercício da acumulação e da coleção a obra de Perec compartilha com a Arte Contemporânea formas e procedimentos, agora, com o arquivo, o foco estará mais na ideia que dá origem ao trabalho, passando a requisitar de maneira mais enfática a participação do leitor que, para reconhecer algum sentido na obra do artista, deve aceitar a tarefa de trabalhar junto, pensando possibilidades e estabelecendo relações.

Apresento a seguir como Perec, estimulado por uma autora do século XI, teve a ideia incomum (para um escritor, pelo menos) de sair às ruas para observar o irrisório e recolher fragmentos de vida urbana para compor uma série de instantâneos. Encontro na obra de Édouard Levé (artista visual e escritor) procedimentos e obsessões semelhantes aos de Perec e para expor como isso se efetiva preciso deixar novamente e por alguns momentos o campo da obra perequiana, para visitar a obra de outros artistas, passar pela Arte Conceitual até chegar, finalmente, à exploração dos não-lugares que Perec e Levé tentaram esgotar.

\footnotetext{
${ }^{313}$ Au départ, tout semble simple: je voulais écrire, et j'ai écrit. [...] je ne fais rien d'autre qu'écrire (sinon gagner le temps d'écrire), je ne sais rien faire d'autre, je n'ai pas voulu apprendre autre chose... J'écris pour vivre et je vis pour écrire, et je n'ai pas été loin d'imaginer que l'écriture et la vie pourraient entièrement se confondre [...]. PEREC. Les gnocchis de l'automne ou Réponse à quelques questions me concernant. (1972). In: Je suis né, 2006, p. 71.
} 


\title{
3.1.1. Um projeto de vida e de morte
}

Lugares... é o lugar de um combate entre a vida e a morte. Um projeto que não realizamos, é um fracasso? Sim se ele é um projeto de vida, não se ele é um projeto de morte. Mas, e se ele é os dois? Um combate muito complicado. Ajuda para viver, obstáculo para viver, de acordo com os momentos. ${ }^{314}$

Philippe Lejeune

Em 1974, como consequência do trabalho que Perec desenvolvia na revista Cause commune e por seu interesse pela vida cotidiana e suas coisas comuns, Paul Virilio encomendou a ele um livro em que ele tratasse do espaço da mesma maneira que tratava os objetos porque, segundo o próprio Virilio: “"as coisas' tomam um lugar, da mesma forma que os acontecimentos" ${ }^{315}$. Perec escreveu então Espèces d'espaces [Espécies de espaços]. Nesse livro, misto de ensaio reflexivo e exercício poético, Perec incluiu a descrição de três projetos de escrita que abordam a relação do homem com o espaço: no capítulo la chambre [o quarto] ele apresenta Fragments d'un travail en cours [Fragmentos de um trabalho em curso], o projeto de um inventário de todos os quartos onde o autor já dormiu; no capítulo l'immeuble [o edifício] ele apresenta Projet de roman [Projeto de romance] - romance que se chamaria La Vie mode d'emploi [A Vida manual de instruções] -, e que trata de uma história que se passa em um prédio de apartamentos na cidade de Paris cuja fachada foi retirada pelo autor, deixando ver tudo o que se passa no seu interior; por último, no capítulo la rue [a rua], ele apresenta Les lieux (Notes sur un travail en cours) [Os lugares (Notas sobre um trabalho em curso)], projeto que Perec detalhava assim:

\author{
Os lugares \\ (Notas sobre um trabalho em curso)
}

Em 1969, eu escolhi, em Paris, 12 lugares (ruas, praças, cruzamentos, uma passagem) que, ou são lugares onde vivi, ou são lugares ligados a lembranças particulares.

Eu me dispus a fazer, a cada mês, a descrição de dois desses lugares. Uma dessas descrições é feita no próprio lugar e deve ser a mais neutra possível: sentado num café, ou andando pela rua, um caderno e uma caneta na mão, eu me esforço por descrever as casas, as lojas, as pessoas que encontro, os cartazes, e de uma maneira geral, todos os detalhes que atraem meu olhar. A outra descrição é feita em um ambiente diferente do lugar: eu me esforço então em descrever de memória o lugar [visitado], e em evocar a partir dele todas as lembranças que me vêm, seja do que aconteceu ali, seja das pessoas que encontrei ali. Quando acabo as descrições, eu

\footnotetext{
${ }^{314}$ Lieux... est le lieu d'un combat entre la vie et la mort. Un projet qu'on ne réalise pas, est-ce un échec? Oui s'il est projet de vie, non s'il est projet de mort. Mais s'il est les deux ? Un combat très compliqué. Aide à vivre, obstacle à vivre, selon les moments. LEJEUNE. La mémoire et l'oblique, 1991, p. 146.

315 [...] because 'things' take place, just as events do. WALKER. Paul Virilio on Georges Perec. In: AA Files 45/46, 2001, p. 16.
} 
as coloco em um envelope que lacro com cera. Em várias ocasiões, eu fui aos lugares que descrevia acompanhado por um amigo(a) fotógrafo que, seja livremente, seja sob minhas indicações, tirava fotos que eu então incluí, sem vê-las (à exceção de uma) nos envelopes correspondentes; eu também acabei incluindo nesses envelopes diversos elementos que poderão servir mais tarde como testemunhos como, por exemplo, bilhetes de metrô, ou ainda notas de consumação, ou entradas de cinema, ou panfletos etc.

Eu recomeço essas descrições a cada ano, tomando cuidado para, graças a um algoritmo [...] (biquadrado latino ortogonal de ordem 12), primeiramente, de descrever cada um desses lugares em um mês diferente do ano, e em segundo lugar, de nunca descrever no mesmo mês a mesma dupla de lugares.

Essa tarefa que, no seu princípio, lembra as "cápsulas do tempo", se estenderá por doze anos, até que todos os lugares tenham sido descritos duas vezes doze vezes. [...] o que eu espero, efetivamente, não é nada além que o traço de um envelhecimento triplo: aquele dos próprios lugares, aquele das minhas lembranças, e aquele da minha escrita. ${ }^{316}$ (Ee, pp. 76-77).

Dos três projetos de escrita apresentados por Perec em Espèces d'espace, o único a ser publicado seria La Vie mode d'emploi (1978), mas tanto esse romance, como Espèces d'espaces (1974), Tentative d'épuisement d'un lieu parisien (1975), W ou le souvenir d'enfance (1975) e Je me souviens (1978), todas essas obras devem muito ao que Perec começou a preparar em Lieux e não conseguiu/quis concluir.

No momento que Perec publica Espèces d'espaces e expõe publicamente o projeto de Lieux, essa obra já estava quase que definitivamente abandonada: o primeiro texto escrito para o projeto é de 27 de janeiro de 1969 e o último é de 27 de setembro de 1975. Dos 288 textos previstos (ou 'lugares', como dizia Perec), em que 144 são 'lembranças' - descrições de

316 Les lieux

(Notes sur un travail en cours)

En 1969, j’ai choisi, dans Paris, 12 lieux (des rues, des places, des carrefours, un passage), ou bien dans lesquels j'avais vécu, ou bien auxquels me rattachaient des souvenirs particuliers. / J'ai entrepris de faire, chaque mois, la description de deux de ces lieux. L'une de ces descriptions se fait sur le lieu même et se veut la plus neutre possible: assis dans un café, ou marchant dans la rue, un carnet et un stylo à la main, je m'efforce de décrire les maisons, les magasins, les gens que je rencontre, les affiches, et, d'une manière générale, tous les détails qui attirent mon regard. L'autre description se fait dans un endroit différent du lieu: je m'efforce alors de décrire le lieu de mémoire, et d'évoquer à son propos tous les souvenirs qui me viennent, soit des événements qui s'y sont déroulés, soit des gens que j’y ai rencontrés. Lorsque ces descriptions sont terminées, je les glisse dans une enveloppe que je scelle à la cire. A plusieurs reprises, je me suis fait accompagner sur les lieux que je décrivais par un ou une ami(e) photographe qui, soit librement, soit sur mes indications, a pris des photos que j'ai alors glissées, sans les regarder (à l'exception d'une seule) dans les enveloppes correspondantes; il m'est arrivé également de glisser dans ces enveloppes divers éléments susceptibles de faire plus tard office de témoignages, par exemple des tickets de métro, ou bien des tickets de consommation, ou des billets de cinéma, ou des prospectus, etc. I Je recommence chaque année ces descriptions en prenant soin, grâce à un algorithme [...] (bi-carré latin orthogonal, celui-ci étant d'ordre 12), premièrement, de décrire chacun de ces lieux en un mois différent de l'année, deuxièmement, de ne jamais décrire le même mois la même couple de lieux. / Cette entreprise, qui n'est pas sans rappeler dans son principe les "bombes du temps", durera donc douze ans, jusqu'à ce que tous les lieux aient été décrits deux fois douze fois. [...] ce que j'en attends, en effet, n'est rien d'autre que la trace d'un triple vieillissement: celui des lieux eux-mêmes, celui de mes souvenirs, et celui de mon écriture. 
memória - e 144 são 'reais' - descrições feitas in situ -, Perec realizou apenas 133. Desses textos, Perec chegou a publicar cinco séries de 'reais' e nenhuma 'lembrança' ${ }^{317}$. Mas antes de abordar os desdobramentos suscitados por essa obra, que tornaram possível um texto como Tentative d'épuisement d'un lieu parisien (que tratarei mais adiante), vou apontar algumas características desse projeto que fazem dele um empreendimento tão instigante.

Lieux é um projeto que, desde o início dos trabalhos de Perec esteve envolto em silêncios, a começar pela justificativa dada pelo autor para a definição dos lugares escolhidos para o projeto, bem como seus objetivos com um trabalho tão longo.

Paul Virilio, amigo do escritor, afirma: “Lieux era um projeto muito pessoal - Perec não falava muito sobre ele conosco. Ele o mencionava, nos mostrava duas ou três coisas, mas não o compartilhava de verdade conosco." ${ }^{318}$ E mesmo na carta que Perec escreveu a Nadeau em 1969 (já mencionada no capítulo 2), na qual o escritor tratava do projeto de um amplo conjunto autobiográfico e do qual Lieux fazia parte, o escritor preferia mencionar números a dizer exatamente o que faria ao final do trabalho:

Eu comecei em janeiro de 1969; eu terei acabado em dezembro de 1980! eu abrirei então os 288 envelopes lacrados, vou relê-los cuidadosamente, copiá-los, estabelecerei os índices necessários. Eu não tenho uma ideia muito clara do resultado final, mas creio que veremos ali ao mesmo tempo o envelhecimento dos lugares, o envelhecimento da minha escrita, o envelhecimento das minhas lembranças $\left[\ldots . .{ }^{319}\right.$

${ }^{317}$ Perec chamou de Tentative de description de quelques lieux parisiens [Tentativa de descrição de alguns lugares parisienses] o conjunto das cinco séries de descrições feitas in situ que compôs e publicou a partir de Lieux. Os títulos das séries e as obras nas quais foram publicadas são: Guettées [Espreitas], in: Les Lettres Nouvelles, 1977, $\mathrm{n}^{\circ} 1$; Vues d'Italie [Vistas da Itália], in: Nouvelle Revue de Psychanalyse, $\mathrm{n}^{\circ}$ 16, 1977; $\underline{\mathrm{La}}$ rue Vilin [A rua Vilin], in: L'Humanité, 11/11/ 1977, e republicada in: PEREC. L'infra-ordinaire, 1989, pp. 15-31; Allées et venues rue de l'Assomption [Idas e vindas rue de l'Assomption], in: L'Arc, n 76, 1979, pp. 77-95; Station Mabillon [Estação Mabillon], in: Action poétique, nº 8, 1980. Em 2001, com exceção da série La rue Vilin, as outras séries foram publicadas em conjunto, em inglês, com tradução de Andrew Leak in: AA Files 45/46, 2001, pp. 32-77.

As únicas descrições de memória tornadas públicas foram publicadas por Lejeune e se referem à Rue Vilin: LEJEUNE. Vilin Souvenirs. Georges Perec [Lembranças Vilin. Georges Perec], In: Genesis, 1992, pp. $127-$ 151. Alguns fragmentos das descrições de memória de Perec também aparecem in: LEJEUNE. La mémoire et l'oblique, 1991.

${ }^{318}$ Lieux was a rather personal project - Perec did not talk much about it to us. He mentioned it, showed us two or three things, but did not really share it with us at all. WALKER. Paul Virilio on Georges Perec. In: AA Files 45/46, 2001, p. 17.

319 J'ai commencé en janvier 1969; j’aurai fini en décembre 1980! j’ouvrirai alors les 288 enveloppes cachetées, les relirai soigneusement, les recopierai, établirai les index nécessaires. Je n'ai pas une idée très claire du résultat final, mais je pense qu'on y verra tout à la fois le vieillissement des lieux, le vieillissement de mon écriture, le vieillissement de mes souvenirs [...]. PEREC. Lettre à Maurice Nadeau. (1969). In: Je suis né, 2006, p. 59. 
Atencioso com os números e com a necessidade de estabelecer um índice ao final dos trabalhos, o escritor projetava para o futuro a configuração da obra, dando a entender que o importante naquele momento seria se deixar levar pelas limitações e rotinas da contrainte que ele mesmo havia estabelecido.

Embora o autor anunciasse que os doze lugares escolhidos para o projeto estariam ligados a fatos e situações de seu passado, ele nunca esclareceria o que justificava exatamente as suas escolhas. Se algumas dessas relações são evidentes, outras são dadas como possíveis por David Bellos ${ }^{320}$ e Lejeune ${ }^{321}$ :

1. Place Jussieu: é próxima de onde Perec e Paulette ${ }^{322}$ moraram entre 1960 e 1966;

2. Rue de l'Assomption: é onde Perec morou com os tios que o acolheram entre 1945 e 1960;

3. Rue Saint-Honoré: Perec morou ali nos anos 1956/57 e 1959;

4. Avenue Junot: é onde moravam sua tia Berthe Chavranski e seu primo Henri;

5. Avenue Franklin-D. Roosevelt: é para onde Perec foi ao fugir da casa dos tios em 1947;

6. Rue de la Gaîté: é próxima de onde morava o amigo Jacques Lederer nos anos cinquenta;

7. Carrefour Mabillon: tem ligação com o início do relacionamento entre Perec e Paulette;

8. Rue Vilin: é o lugar onde Perec viveu entre 1936 e 1942;

9. Place d'Italie: é onde morava seu amigo Michel e onde Perec teria datilografado, entre 1955-56, seu primeiro romance (inédito): Les errants [Os errantes];

10. L'île Saint-Louis: é onde Suzanne Lipinska, paixão do escritor em 1968, ficava hospedada quando vinha a Paris;

11. Passage Choiseul: ainda não se sabe o que atraía Perec a esse lugar;

12. Place de la Contrescarpe: é próxima de onde moravam os amigos tunisianos de Perec entre os anos 1956-57.

\footnotetext{
${ }^{320}$ BELLOS. Georges Perec, 1994, pp. 439-440.

${ }^{321}$ LEJEUNE. La mémoire et l'oblique, 1991, p. 164.

${ }^{322}$ Paulette Perec (Paulette Pétras) se casou com Perec em 1960. Os dois se separaram em 1969 e se divorciaram em 1980.
} 
Um mapa feito por Bellos (fig. 17) indica todos os lugares escolhidos por Perec e nos dá uma ideia do circuito formado por eles na cidade de Paris. Através do mapa é possível fazer um deslocamento com os olhos pelos doze lugares do projeto perequiano e seguir um percurso imaginário por essa cidade. Começaríamos nos perguntando: como faríamos? De onde se partiria? Que tempo isso levaria? O que, ou quem, se encontraria? O que se veria? Do que seria possível se lembrar? Perec propôs para si esse exercício mensal que duraria doze anos.

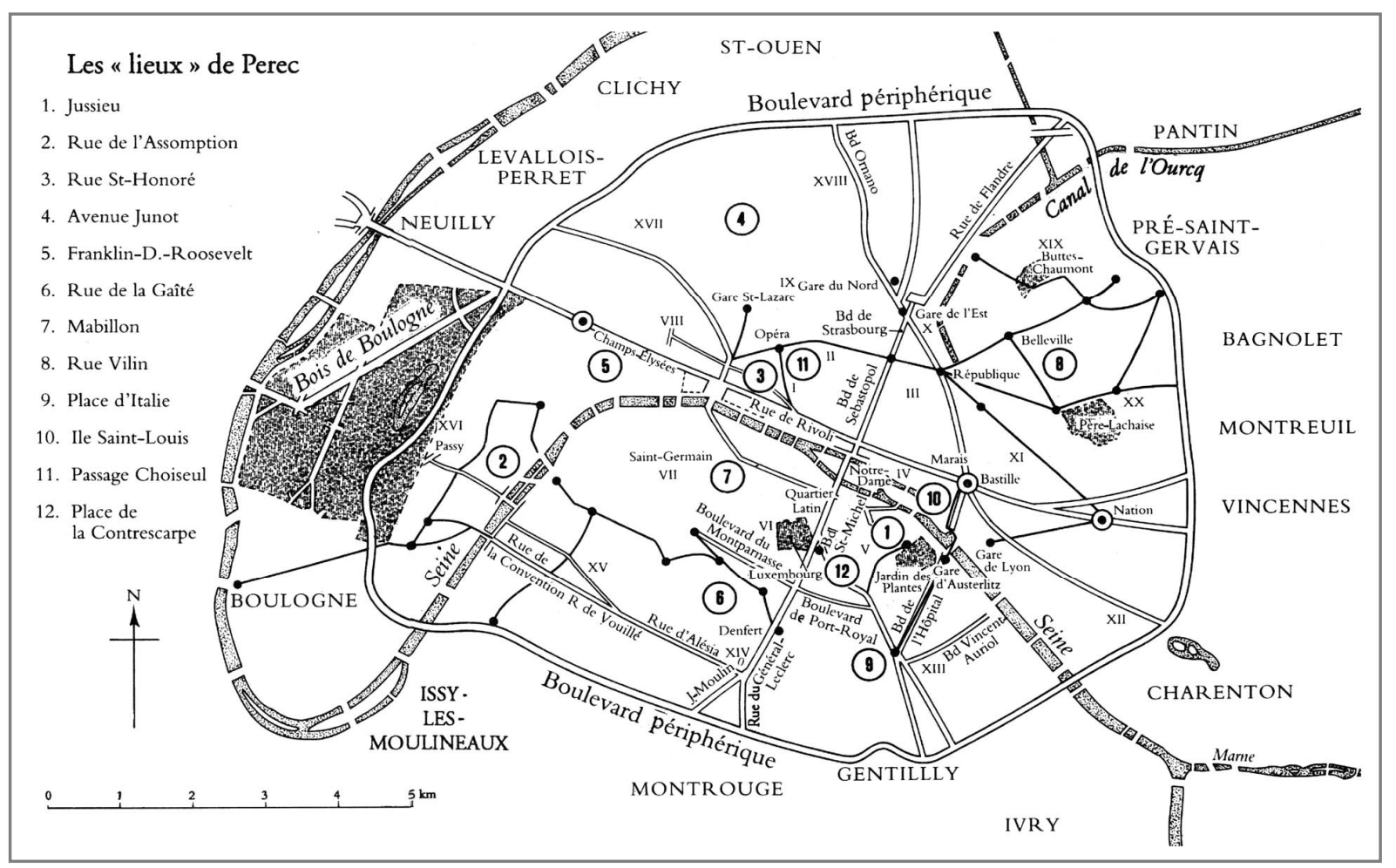

Figura 17 - Os 'lugares' de Perec.

Antes de começar esse projeto, durante as reuniões com os colegas do OuLiPo, Perec tomou conhecimento de um exercício de permutação que poderia ser feito através de fórmulas tiradas de uma ramificação da Matemática chamada 'combinatória'. Perec entrou então em contato com um matemático hindu que morava nos Estados Unidos - Indra Chakravarti - e pediu a ele que preparasse dois quadrados latinos de ordem 12, mutuamente ortogonais que Perec fundiria num único quadro (fig. 18). Perec precisava disso para ter a certeza que, ao longo de doze anos, ele nunca repetiria a mesma dupla de textos e que ele não deixaria, ao longo de um ano, de visitar e de se lembrar de todos os lugares. 
Com os dois quadrados latinos de ordem 12 em mãos, Perec definiu um número para cada um dos doze lugares. Agora, cada linha do quadro (fig. 18) representaria um ano do projeto e cada célula corresponderia a um dos doze meses do ano. No interior das células do quadro a dupla de números indicaria os dois textos (a 'lembrança' e o 'real') que Perec deveria escrever (cf. o projeto completo

\begin{tabular}{|l|l|l|l|l|l|l|l|l|l|l|l|}
\hline 1,1 & 2,2 & 3,3 & 4,4 & 5,5 & 6,6 & 7,7 & 8,8 & 9,9 & 10,10 & 11,11 & 12,12 \\
\hline 2,3 & 3,4 & 4,5 & 5,6 & 6,1 & 1,2 & 8,9 & 9,10 & 10,11 & 11,12 & 12,7 & 7,8 \\
\hline 3,2 & 4,3 & 5,4 & 6,5 & 1,6 & 2,1 & 9,8 & 10,9 & 11,10 & 12,11 & 7,12 & 8,7 \\
\hline 4,11 & 5,12 & 6,7 & 1,8 & 2,9 & 3,10 & 10,5 & 11,6 & 12,1 & 7,2 & 8,3 & 9,4 \\
\hline 5,10 & 6,11 & 1,12 & 2,7 & 3,8 & 4,9 & 11,4 & 12,5 & 7,6 & 8,1 & 9,2 & 10,3 \\
\hline 6,12 & 1,7 & 2,8 & 3,9 & 4,10 & 5,11 & 12,6 & 7,1 & 8,2 & 9,3 & 10,4 & 11,5 \\
\hline 7,4 & 8,5 & 9,6 & 10,1 & 11,2 & 12,3 & 1,10 & 2,11 & 3,12 & 4,7 & 5,8 & 6,9 \\
\hline 8,6 & 9,1 & 10,2 & 11,3 & 12,4 & 7,5 & 2,12 & 3,7 & 4,8 & 5,9 & 6,10 & 1,11 \\
\hline 9,5 & 10,6 & 11,1 & 12,2 & 7,3 & 8,4 & 3,11 & 4,12 & 5,7 & 6,8 & 1,9 & 2,10 \\
\hline 10,8 & 11,9 & 12,10 & 7,11 & 8,12 & 9,7 & 4,2 & 5,3 & 6,4 & 1,5 & 2,6 & 3,1 \\
\hline 11,7 & 12,8 & 7,9 & 8,10 & 9,11 & 10,12 & 5,1 & 6,2 & 1,3 & 2,4 & 3,5 & 4,6 \\
\hline 12,9 & 7,10 & 8,11 & 9,12 & 10,7 & 11,8 & 6,3 & 1,4 & 2,5 & 3,6 & 4,1 & 5,2 \\
\hline
\end{tabular}

Figura 18 - Biquadrado latino de ordem 12. na Tabela 1).

Para que no primeiro ano do projeto não houvesse a coincidência do mesmo lugar para os dois textos (cf. a primeira linha da fig. 18), Perec definiu uma correspondência diferente dos lugares com os números (cf. Tabela 2): agora, mesmo com os números iguais no primeiro ano do projeto, eles indicariam o trabalho com lugares distintos ${ }^{323}$.

Na Tabela 1 encontra-se todo o plano de escrita do projeto onde, para cada mês, estão definidos os números em ordem cronológica dos textos que seriam escritos e guardados em envelopes, e a indicação dos lugares que deveriam ser lembrados e visitados ${ }^{324}$. Dos 160 textos previstos para o período em que o projeto de Perec esteve ativo ele escreveu efetivamente 133. O período mais longo de inatividade do projeto ocorreu entre 1973 e 1974, quando Lejeune indica que Perec deixou o projeto por 18 meses $^{325}$.

${ }^{323}$ Isso não impedia que essa coincidência ocorresse em outro momento. Exemplo disso está em outubro de 1974 (cf. Tabela 1) com os textos de no 139 e 140: os lugares ' 9 ' e ' 3 ' correspondem à lembrança e ao real da mesma Place d'Italie (cf. Tabela 2).

As Tabelas 1 e 2 foram elaboradas a partir dos dados obtidos in: LEJEUNE. La mémoire et l'oblique, 1991, pp. 153-157; e BELLOS. Georges Perec, 1994, pp. 442-443.

$324 \mathrm{Na}$ maioria das vezes, os textos de numeração impar correspondem às lembranças enquanto que os de numeração par correspondem às descrições feitas in situ. Como salienta Lejeune, isso não significava que, todo mês, Perec devesse retomar o projeto começando a escrever uma lembrança para depois se dirigir a um dos doze lugares para descrevê-lo. Perec não definiu no projeto esse tipo de procedimento. Cf. LEJEUNE. Op. cit., p. 154.

${ }^{325}$ No livro de Lejeune não estão especificados quais são exatamente os 133 textos escritos e por essa razão mantive na Tabela 1 a indicação dos 160 textos que deveriam ter sido escritos durante esse período. Desde muito cedo, Perec deixou de seguir o ritmo previsto pela contrainte inicial e começou a atrasar a escrita, principalmente dos 'reais'. Para recuperar o tempo perdido, Perec precisou em muitas ocasiões escrever em um único mês vários textos atrasados. Ainda que esse procedimento não atrapalhasse a ordem dos textos escritos, isso aumentava o risco da coincidência de se ter, num mesmo mês, que trabalhar os 'reais' e as 'lembranças' de um mesmo lugar - o que de início o autor queria evitar. Cf. EE, pp. 76-77. 


\begin{tabular}{|c|c|c|c|c|c|c|c|c|c|c|c|c|}
\hline & \multicolumn{12}{|c|}{ Tabela 1} \\
\hline & \multicolumn{12}{|c|}{ Distribuição dos textos do projeto Lieux } \\
\hline & jan & fev & mar & $a b r$ & mai & jun & jul & ago & set & out & nov & dez \\
\hline \multirow{2}{*}{$\begin{array}{l}\text { ○े } \\
\text { જે }\end{array}$} & $\begin{array}{c}\text { Textos } \\
1,2 \\
\end{array}$ & $\begin{array}{c}\text { Textos } \\
3,4\end{array}$ & $\begin{array}{c}\text { Textos } \\
5,6\end{array}$ & $\begin{array}{c}\text { Textos } \\
7,8\end{array}$ & $\begin{array}{c}\text { Textos } \\
9,10\end{array}$ & $\begin{array}{l}\text { Textos } \\
11,12 \\
\end{array}$ & $\begin{array}{l}\text { Textos } \\
13,14 \\
\end{array}$ & $\begin{array}{l}\text { Textos } \\
15,16 \\
\end{array}$ & $\begin{array}{c}\text { Textos } \\
17,18 \\
\end{array}$ & $\begin{array}{l}\text { Textos } \\
19,20 \\
\end{array}$ & $\begin{array}{l}\text { Textos } \\
21,22 \\
\end{array}$ & $\begin{array}{l}\text { Textos } \\
23,24 \\
\end{array}$ \\
\hline & $\begin{array}{c}\text { Lugares } \\
1,1 \\
\end{array}$ & $\begin{array}{c}\text { Lugares } \\
2,2 \\
\end{array}$ & $\begin{array}{c}\text { Lugares } \\
3,3\end{array}$ & $\begin{array}{c}\text { Lugares } \\
4,4\end{array}$ & $\begin{array}{c}\text { Lugares } \\
5,5\end{array}$ & $\begin{array}{c}\text { Lugares } \\
6,6\end{array}$ & $\begin{array}{c}\text { Lugares } \\
7,7\end{array}$ & $\begin{array}{c}\text { Lugares } \\
8,8\end{array}$ & $\begin{array}{c}\text { Lugares } \\
9,9\end{array}$ & $\begin{array}{c}\text { Lugares } \\
10,10\end{array}$ & $\begin{array}{c}\text { Lugares } \\
11,11 \\
\end{array}$ & $\begin{array}{c}\text { Lugares } \\
12,12 \\
\end{array}$ \\
\hline \multirow{2}{*}{ 六 } & $\begin{array}{l}\text { Textos } \\
25,26 \\
\end{array}$ & $\begin{array}{l}\text { Textos } \\
27,28 \\
\end{array}$ & $\begin{array}{l}\text { Textos } \\
29,30 \\
\end{array}$ & $\begin{array}{l}\text { Textos } \\
31,32 \\
\end{array}$ & $\begin{array}{c}\text { Textos } \\
33,34 \\
\end{array}$ & $\begin{array}{l}\text { Textos } \\
35,36\end{array}$ & $\begin{array}{c}\text { Textos } \\
37,38\end{array}$ & $\begin{array}{c}\text { Textos } \\
39,40\end{array}$ & $\begin{array}{l}\text { Textos } \\
41,42\end{array}$ & $\begin{array}{c}\text { Textos } \\
43,44\end{array}$ & $\begin{array}{l}\text { Textos } \\
45,46\end{array}$ & $\begin{array}{c}\text { Textos } \\
47,48\end{array}$ \\
\hline & $\begin{array}{c}\text { Lugares } \\
2,3 \\
\end{array}$ & $\begin{array}{c}\text { Lugares } \\
3,4 \\
\end{array}$ & $\begin{array}{c}\text { Lugares } \\
4,5 \\
\end{array}$ & $\begin{array}{c}\text { Lugares } \\
5,6 \\
\end{array}$ & $\begin{array}{c}\text { Lugares } \\
6,1 \\
\end{array}$ & $\begin{array}{c}\text { Lugares } \\
1,2 \\
\end{array}$ & $\begin{array}{c}\text { Lugares } \\
8,9 \\
\end{array}$ & $\begin{array}{c}\text { Lugares } \\
9,10 \\
\end{array}$ & $\begin{array}{c}\text { Lugares } \\
10,11 \\
\end{array}$ & $\begin{array}{c}\text { Lugares } \\
11,12 \\
\end{array}$ & $\begin{array}{c}\text { Lugares } \\
12,7 \\
\end{array}$ & $\begin{array}{c}\text { Lugares } \\
7,8 \\
\end{array}$ \\
\hline \multirow{2}{*}{ ત્ન } & $\begin{array}{l}\text { Textos } \\
49,50 \\
\end{array}$ & $\begin{array}{c}\text { Textos } \\
51,52 \\
\end{array}$ & $\begin{array}{c}\text { Textos } \\
53,54 \\
\end{array}$ & $\begin{array}{c}\text { Textos } \\
55,56 \\
\end{array}$ & $\begin{array}{c}\text { Textos } \\
57,58 \\
\end{array}$ & $\begin{array}{c}\text { Textos } \\
59,60 \\
\end{array}$ & $\begin{array}{l}\text { Textos } \\
61,62 \\
\end{array}$ & $\begin{array}{l}\text { Textos } \\
63,64 \\
\end{array}$ & & $\begin{array}{c}\text { Textos } \\
67,68 \\
\end{array}$ & $\begin{array}{l}\text { Textos } \\
69,70 \\
\end{array}$ & $\begin{array}{l}\text { Textos } \\
71,72 \\
\end{array}$ \\
\hline & $\begin{array}{c}\text { Lugares } \\
3,2 \\
\end{array}$ & $\begin{array}{c}\text { Lugares } \\
4,3 \\
\end{array}$ & $\begin{array}{c}\text { Lugares } \\
5,4 \\
\end{array}$ & $\begin{array}{c}\text { Lugares } \\
6,5 \\
\end{array}$ & $\begin{array}{c}\text { Lugares } \\
1,6 \\
\end{array}$ & $\begin{array}{c}\text { Lugares } \\
2,1 \\
\end{array}$ & $\begin{array}{c}\text { Lugares } \\
9,8 \\
\end{array}$ & $\begin{array}{c}\text { Lugares } \\
10,9 \\
\end{array}$ & $\begin{array}{c}\text { Lugares } \\
11,10 \\
\end{array}$ & $\begin{array}{c}\text { Lugares } \\
12,11 \\
\end{array}$ & $\begin{array}{c}\text { Lugares } \\
7,12 \\
\end{array}$ & $\begin{array}{c}\text { Lugares } \\
8,7 \\
\end{array}$ \\
\hline \multirow{2}{*}{ Nิ } & $\begin{array}{l}\text { Textos } \\
73,74 \\
\end{array}$ & $\begin{array}{l}\text { Textos } \\
75,76\end{array}$ & $\begin{array}{l}\text { Textos } \\
77,78\end{array}$ & $\begin{array}{l}\text { Textos } \\
79,80 \\
\end{array}$ & $\begin{array}{l}\text { Textos } \\
81,82\end{array}$ & $\begin{array}{l}\text { Textos } \\
83,84\end{array}$ & $\begin{array}{l}\text { Textos } \\
85,86\end{array}$ & $\begin{array}{c}\text { Textos } \\
87,88\end{array}$ & $\begin{array}{l}\text { Textos } \\
89,90\end{array}$ & $\begin{array}{l}\text { Textos } \\
91,92 \\
\end{array}$ & $\begin{array}{l}\text { Textos } \\
93,94\end{array}$ & $\begin{array}{l}\text { Textos } \\
95,96\end{array}$ \\
\hline & $\begin{array}{c}\text { Lugares } \\
4,11 \\
\end{array}$ & $\begin{array}{c}\text { Lugares } \\
5,12 \\
\end{array}$ & $\begin{array}{c}\text { Lugares } \\
6,7 \\
\end{array}$ & $\begin{array}{c}\text { Lugares } \\
1,8 \\
\end{array}$ & $\begin{array}{c}\text { Lugares } \\
2,9 \\
\end{array}$ & $\begin{array}{c}\text { Lugares } \\
3,10 \\
\end{array}$ & $\begin{array}{c}\text { Lugares } \\
10,5 \\
\end{array}$ & $\begin{array}{c}\text { Lugares } \\
11,6 \\
\end{array}$ & $\begin{array}{c}\text { Lugares } \\
12,1 \\
\end{array}$ & $\begin{array}{c}\text { Lugares } \\
7,2 \\
\end{array}$ & $\begin{array}{c}\text { Lugares } \\
8,3 \\
\end{array}$ & $\begin{array}{c}\text { Lugares } \\
9,4 \\
\end{array}$ \\
\hline \multirow{2}{*}{$\stackrel{\text { M }}{\stackrel{-}{-}}$} & $\begin{array}{l}\text { Textos } \\
97,98 \\
\end{array}$ & $\begin{array}{c}\text { Textos } \\
99,100 \\
\end{array}$ & $\begin{array}{c}\text { Textos } \\
101,102\end{array}$ & $\begin{array}{c}\text { Textos } \\
103,104 \\
\end{array}$ & $\begin{array}{c}\text { Textos } \\
105,106 \\
\end{array}$ & $\begin{array}{c}\text { Textos } \\
107,108 \\
\end{array}$ & $\begin{array}{c}\text { Textos } \\
109,110 \\
\end{array}$ & $\begin{array}{c}\text { Textos } \\
111,112 \\
\end{array}$ & & & & $\begin{array}{c}\text { Textos } \\
119,120 \\
\end{array}$ \\
\hline & $\begin{array}{c}\text { Lugares } \\
5,10 \\
\end{array}$ & $\begin{array}{c}\text { Lugares } \\
6,11 \\
\end{array}$ & $\begin{array}{c}\text { Lugares } \\
1,12 \\
\end{array}$ & $\begin{array}{c}\text { Lugares } \\
2,7 \\
\end{array}$ & $\begin{array}{c}\text { Lugares } \\
3,8 \\
\end{array}$ & $\begin{array}{c}\text { Lugares } \\
4,9 \\
\end{array}$ & $\begin{array}{c}\text { Lugares } \\
11,4 \\
\end{array}$ & $\begin{array}{c}\text { Lugares } \\
12,5 \\
\end{array}$ & $\begin{array}{c}\text { Lugares } \\
7,6 \\
\end{array}$ & $\begin{array}{c}\text { Lugares } \\
8,1 \\
\end{array}$ & $\begin{array}{c}\text { Lugares } \\
9,2 \\
\end{array}$ & $\begin{array}{c}\text { Lugares } \\
10,3 \\
\end{array}$ \\
\hline \multirow{2}{*}{ ホ̊ } & $\begin{array}{c}\text { Textos } \\
121,122\end{array}$ & $\begin{array}{c}\text { Textos } \\
123,124\end{array}$ & $\begin{array}{c}\text { Textos } \\
125,126\end{array}$ & $\begin{array}{c}\text { Textos } \\
127,128\end{array}$ & $\begin{array}{c}\text { Textos } \\
129,130\end{array}$ & $\begin{array}{c}\text { Textos } \\
131,132\end{array}$ & $\begin{array}{c}\text { Textos } \\
133,134\end{array}$ & $\begin{array}{c}\text { Textos } \\
135,136\end{array}$ & $\begin{array}{c}\text { Textos } \\
137,138\end{array}$ & $\begin{array}{c}\text { Textos } \\
139,140\end{array}$ & $\begin{array}{c}\text { Textos } \\
141,142\end{array}$ & $\begin{array}{c}\text { Textos } \\
143,144\end{array}$ \\
\hline & $\begin{array}{c}\text { Lugares } \\
6,12 \\
\end{array}$ & $\begin{array}{c}\text { Lugares } \\
1,7 \\
\end{array}$ & $\begin{array}{c}\text { Lugares } \\
2,8 \\
\end{array}$ & $\begin{array}{c}\text { Lugares } \\
3,9 \\
\end{array}$ & $\begin{array}{c}\text { Lugares } \\
4,10 \\
\end{array}$ & $\begin{array}{c}\text { Lugares } \\
5,11 \\
\end{array}$ & $\begin{array}{c}\text { Lugares } \\
12,6 \\
\end{array}$ & $\begin{array}{c}\text { Lugares } \\
7,1 \\
\end{array}$ & $\begin{array}{c}\text { Lugares } \\
8,2 \\
\end{array}$ & $\begin{array}{c}\text { Lugares } \\
9,3 \\
\end{array}$ & $\begin{array}{c}\text { Lugares } \\
10,4 \\
\end{array}$ & $\begin{array}{c}\text { Lugares } \\
11,5 \\
\end{array}$ \\
\hline \multirow{2}{*}{ م } & $\begin{array}{c}\text { Textos } \\
145,146\end{array}$ & $\begin{array}{c}\text { Textos } \\
147,148 \\
\end{array}$ & $\begin{array}{c}\text { Textos } \\
149,150\end{array}$ & $\begin{array}{c}\text { Textos } \\
151,152 \\
\end{array}$ & $\begin{array}{c}\text { Textos } \\
154,154 \\
\end{array}$ & $\begin{array}{c}\text { Textos } \\
155,156\end{array}$ & $\begin{array}{c}\text { Textos } \\
157,158 \\
\end{array}$ & $\begin{array}{c}\text { Textos } \\
159,160 \\
\end{array}$ & $\begin{array}{c}\text { Textos } \\
161,162\end{array}$ & $\begin{array}{c}\text { Textos } \\
163,164\end{array}$ & $\begin{array}{c}\text { Textos } \\
165,166\end{array}$ & $\begin{array}{c}\text { Textos } \\
167,168\end{array}$ \\
\hline & $\begin{array}{c}\text { Lugares } \\
7,4\end{array}$ & $\begin{array}{c}\text { Lugares } \\
8,5 \\
\end{array}$ & $\begin{array}{c}\text { Lugares } \\
9,6\end{array}$ & $\begin{array}{c}\text { Lugares } \\
10,1 \\
\end{array}$ & $\begin{array}{c}\text { Lugares } \\
11,2 \\
\end{array}$ & $\begin{array}{c}\text { Lugares } \\
12,3 \\
\end{array}$ & $\begin{array}{c}\text { Lugares } \\
1,10 \\
\end{array}$ & $\begin{array}{c}\text { Lugares } \\
2,11 \\
\end{array}$ & $\begin{array}{c}\text { Lugares } \\
3,12\end{array}$ & $\begin{array}{c}\text { Lugares } \\
4,7 \\
\end{array}$ & $\begin{array}{c}\text { Lugares } \\
5,8\end{array}$ & $\begin{array}{c}\text { Lugares } \\
6,9 \\
\end{array}$ \\
\hline \multirow{2}{*}{$\begin{array}{l}\stackrel{0}{\hat{~}} \\
\stackrel{-}{-}\end{array}$} & $\begin{array}{c}\text { Textos } \\
169,170 \\
\end{array}$ & $\begin{array}{c}\text { Textos } \\
171,172 \\
\end{array}$ & $\begin{array}{c}\text { Textos } \\
173,174\end{array}$ & $\begin{array}{c}\text { Textos } \\
175,176 \\
\end{array}$ & $\begin{array}{c}\text { Textos } \\
177,178 \\
\end{array}$ & $\begin{array}{c}\text { Textos } \\
179,180 \\
\end{array}$ & $\begin{array}{c}\text { Textos } \\
181,182\end{array}$ & $\begin{array}{c}\text { Textos } \\
183,184 \\
\end{array}$ & $\begin{array}{c}\text { Textos } \\
185,186 \\
\end{array}$ & $\begin{array}{c}\text { Textos } \\
187,188 \\
\end{array}$ & $\begin{array}{c}\text { Textos } \\
189,190 \\
\end{array}$ & $\begin{array}{c}\text { Textos } \\
191,192 \\
\end{array}$ \\
\hline & $\begin{array}{c}\text { Lugares } \\
8,6 \\
\end{array}$ & $\begin{array}{c}\text { Lugares } \\
9,1 \\
\end{array}$ & $\begin{array}{c}\text { Lugares } \\
10,2 \\
\end{array}$ & $\begin{array}{c}\text { Lugares } \\
11,3 \\
\end{array}$ & $\begin{array}{c}\text { Lugares } \\
12,4 \\
\end{array}$ & $\begin{array}{c}\text { Lugares } \\
7,5 \\
\end{array}$ & $\begin{array}{c}\text { Lugares } \\
2,12 \\
\end{array}$ & $\begin{array}{c}\text { Lugares } \\
3,7 \\
\end{array}$ & $\begin{array}{c}\text { Lugares } \\
4,8 \\
\end{array}$ & $\begin{array}{c}\text { Lugares } \\
5,9 \\
\end{array}$ & $\begin{array}{c}\text { Lugares } \\
6,10 \\
\end{array}$ & $\begin{array}{c}\text { Lugares } \\
1,11 \\
\end{array}$ \\
\hline \multirow{2}{*}{$\underset{\text { مે }}{\hat{\sigma}}$} & $\begin{array}{c}\text { Textos } \\
193,194 \\
\end{array}$ & $\begin{array}{c}\text { Textos } \\
195,196 \\
\end{array}$ & $\begin{array}{c}\text { Textos } \\
197,198 \\
\end{array}$ & $\begin{array}{c}\text { Textos } \\
199,200 \\
\end{array}$ & $\begin{array}{c}\text { Textos } \\
201,202 \\
\end{array}$ & $\begin{array}{c}\text { Textos } \\
203,204 \\
\end{array}$ & $\begin{array}{c}\text { Textos } \\
205,206\end{array}$ & $\begin{array}{c}\text { Textos } \\
207,208 \\
\end{array}$ & $\begin{array}{c}\text { Textos } \\
209,210\end{array}$ & $\begin{array}{c}\text { Textos } \\
211,212 \\
\end{array}$ & $\begin{array}{c}\text { Textos } \\
213,214 \\
\end{array}$ & $\begin{array}{c}\text { Textos } \\
215,216 \\
\end{array}$ \\
\hline & $\begin{array}{c}\text { Lugares } \\
9,5 \\
\end{array}$ & $\begin{array}{c}\text { Lugares } \\
10,6 \\
\end{array}$ & $\begin{array}{c}\text { Lugares } \\
11,1 \\
\end{array}$ & $\begin{array}{c}\text { Lugares } \\
12,2 \\
\end{array}$ & $\begin{array}{c}\text { Lugares } \\
7,3 \\
\end{array}$ & $\begin{array}{c}\text { Lugares } \\
8,4 \\
\end{array}$ & $\begin{array}{c}\text { Lugares } \\
3,11 \\
\end{array}$ & $\begin{array}{c}\text { Lugares } \\
4,12 \\
\end{array}$ & $\begin{array}{c}\text { Lugares } \\
5,7 \\
\end{array}$ & $\begin{array}{c}\text { Lugares } \\
6,8 \\
\end{array}$ & $\begin{array}{c}\text { Lugares } \\
1,9 \\
\end{array}$ & $\begin{array}{c}\text { Lugares } \\
2,10 \\
\end{array}$ \\
\hline \multirow{2}{*}{ 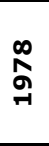 } & $\begin{array}{c}\text { Textos } \\
217,218 \\
\end{array}$ & $\begin{array}{c}\text { Textos } \\
219,220 \\
\end{array}$ & $\begin{array}{c}\text { Textos } \\
221,222 \\
\end{array}$ & $\begin{array}{c}\text { Textos } \\
223,224 \\
\end{array}$ & $\begin{array}{c}\text { Textos } \\
225,226 \\
\end{array}$ & $\begin{array}{c}\text { Textos } \\
227,228 \\
\end{array}$ & $\begin{array}{c}\text { Textos } \\
229,230 \\
\end{array}$ & $\begin{array}{c}\text { Textos } \\
231,232 \\
\end{array}$ & $\begin{array}{c}\text { Textos } \\
233,234 \\
\end{array}$ & $\begin{array}{c}\text { Textos } \\
235,236 \\
\end{array}$ & $\begin{array}{c}\text { Textos } \\
237,238 \\
\end{array}$ & $\begin{array}{c}\text { Textos } \\
239,240 \\
\end{array}$ \\
\hline & $\begin{array}{c}\text { Lugares } \\
10,8 \\
\end{array}$ & $\begin{array}{c}\text { Lugares } \\
11,9 \\
\end{array}$ & $\begin{array}{c}\text { Lugares } \\
12,10 \\
\end{array}$ & $\begin{array}{c}\text { Lugares } \\
7,11 \\
\end{array}$ & $\begin{array}{c}\text { Lugares } \\
8,12 \\
\end{array}$ & $\begin{array}{c}\text { Lugares } \\
9,7 \\
\end{array}$ & $\begin{array}{c}\text { Lugares } \\
4,2 \\
\end{array}$ & $\begin{array}{c}\text { Lugares } \\
5,3 \\
\end{array}$ & $\begin{array}{c}\text { Lugares } \\
6,4 \\
\end{array}$ & $\begin{array}{c}\text { Lugares } \\
1,5 \\
\end{array}$ & $\begin{array}{c}\text { Lugares } \\
2,6 \\
\end{array}$ & $\begin{array}{c}\text { Lugares } \\
3,1 \\
\end{array}$ \\
\hline \multirow{2}{*}{ م્ } & $\begin{array}{c}\text { Textos } \\
241,242\end{array}$ & $\begin{array}{c}\text { Textos } \\
243,244\end{array}$ & $\begin{array}{c}\text { Textos } \\
245,246\end{array}$ & $\begin{array}{c}\text { Textos } \\
247,248\end{array}$ & $\begin{array}{c}\text { Textos } \\
249,250\end{array}$ & $\begin{array}{c}\text { Textos } \\
251,252 \\
\end{array}$ & $\begin{array}{c}\text { Textos } \\
253,254\end{array}$ & $\begin{array}{c}\text { Textos } \\
255,256 \\
\end{array}$ & $\begin{array}{c}\text { Textos } \\
257,258 \\
\end{array}$ & $\begin{array}{c}\text { Textos } \\
259,260 \\
\end{array}$ & $\begin{array}{c}\text { Textos } \\
261,262\end{array}$ & $\begin{array}{c}\text { Textos } \\
263,264\end{array}$ \\
\hline & $\begin{array}{c}\text { Lugares } \\
11,7 \\
\end{array}$ & $\begin{array}{c}\text { Lugares } \\
12,8 \\
\end{array}$ & $\begin{array}{c}\text { Lugares } \\
7,9 \\
\end{array}$ & $\begin{array}{c}\text { Lugares } \\
8,10 \\
\end{array}$ & $\begin{array}{c}\text { Lugares } \\
9,11\end{array}$ & $\begin{array}{c}\text { Lugares } \\
10,12 \\
\end{array}$ & $\begin{array}{c}\text { Lugares } \\
5,1 \\
\end{array}$ & $\begin{array}{c}\text { Lugares } \\
6,2 \\
\end{array}$ & $\begin{array}{c}\text { Lugares } \\
1,3 \\
\end{array}$ & $\begin{array}{c}\text { Lugares } \\
2,4\end{array}$ & $\begin{array}{c}\text { Lugares } \\
3,5 \\
\end{array}$ & $\begin{array}{c}\text { Lugares } \\
4,6 \\
\end{array}$ \\
\hline \multirow{2}{*}{$\begin{array}{l}\stackrel{\circ}{\circ} \\
\stackrel{\leftrightarrow}{-}\end{array}$} & $\begin{array}{c}\text { Textos } \\
265,266\end{array}$ & $\begin{array}{c}\text { Textos } \\
267,268\end{array}$ & $\begin{array}{c}\text { Textos } \\
269,270\end{array}$ & $\begin{array}{c}\text { Textos } \\
271,272\end{array}$ & $\begin{array}{c}\text { Textos } \\
273,274\end{array}$ & $\begin{array}{c}\text { Textos } \\
275,276\end{array}$ & $\begin{array}{c}\text { Textos } \\
277,278\end{array}$ & $\begin{array}{c}\text { Textos } \\
279,280\end{array}$ & $\begin{array}{c}\text { Textos } \\
281,282 \\
\end{array}$ & $\begin{array}{c}\text { Textos } \\
283,284\end{array}$ & $\begin{array}{c}\text { Textos } \\
285,286 \\
\end{array}$ & $\begin{array}{c}\text { Textos } \\
287,288\end{array}$ \\
\hline & $\begin{array}{c}\text { Lugares } \\
12,9 \\
\end{array}$ & $\begin{array}{c}\text { Lugares } \\
7,10 \\
\end{array}$ & $\begin{array}{c}\text { Lugares } \\
8,11 \\
\end{array}$ & $\begin{array}{c}\text { Lugares } \\
9,12 \\
\end{array}$ & $\begin{array}{c}\text { Lugares } \\
10,7 \\
\end{array}$ & $\begin{array}{c}\text { Lugares } \\
11,8 \\
\end{array}$ & $\begin{array}{c}\text { Lugares } \\
6,3 \\
\end{array}$ & $\begin{array}{c}\text { Lugares } \\
1,4 \\
\end{array}$ & $\begin{array}{c}\text { Lugares } \\
2,5 \\
\end{array}$ & $\begin{array}{c}\text { Lugares } \\
3,6\end{array}$ & $\begin{array}{c}\text { Lugares } \\
4,1 \\
\end{array}$ & $\begin{array}{c}\text { Lugares } \\
5,2 \\
\end{array}$ \\
\hline
\end{tabular}

\section{Textos:}

indica a distribuição das duplas de textos do projeto Lieux indica os textos a serem escritos:

- o primeiro é uma descrição de memória - a lembrança;

o segundo é uma descrição feita in situ. - o real.

(para a identificação dos lugares, consultar a Tabela 2) 
Quanto aos textos escritos ao longo do projeto, Perec explica na carta que escreveu a Nadeau que trabalhava de maneira distinta os dois tipos de texto. Para os textos referentes às descrições feitas in situ ele escreve:

[...] eu descrevo 'isso que eu vejo' da maneira o mais neutra possível, eu enumero as lojas, alguns detalhes de arquitetura, alguns microacontecimentos (uma viatura de bombeiros que passa, uma senhora que amarra seu cachorro antes de entrar numa salsicharia, uma mudança, cartazes, pessoas etc.) ${ }^{326}$

Já, para as descrições feitas de memória, o procedimento de Perec era diferente: “[...] não importa onde (na minha casa, no café, no escritório) eu descrevo o lugar de memória, eu evoco as lembranças que são ligadas a ele, as pessoas que eu conheci ali etc." 327

Nessas duas situações, o próprio exercício físico da escrita era diferente para cada tipo de texto: se para as descrições feitas in situ, Perec tinha que escrever muitas vezes em pé e em movimento, tendo que prestar atenção a tudo o que se passava a sua volta (como acontece com qualquer pedestre), produzindo textos que dão uma impressão de afobação e se compõem de conjuntos de fragmentos, para as descrições de memória, ele podia escrevê-las onde preferisse e sem limitação de tempo.

Segundo Lejeune, as descrições feitas in situ funcionam como um 'diário do presente', já que o autor está no próprio local que descreve e passa para o papel o que vê à sua frente. Sobre isso, Lejeune escreve: "estamos nos lugares, temos algo preciso para fazer; a matéria a tratar [...] está sob seus olhos; o começo e o fim do texto, sua ordem, são

\begin{tabular}{|c|c|c|}
\hline \multicolumn{3}{|c|}{ Tabela 2 } \\
\hline \multicolumn{3}{|c|}{ Correspondência lugares / números } \\
no projeto Lieux \\
\hline $\mathbf{n} \mathbf{0}$ & lembrança & real \\
\hline $\mathbf{1}$ & Jussieu & Mabillon \\
\hline $\mathbf{2}$ & Assomption & Vilin \\
\hline $\mathbf{3}$ & Saint-Honoré & Italie \\
\hline $\mathbf{4}$ & Junot & Saint-Louis \\
\hline $\mathbf{5}$ & Franklin & Choiseul \\
\hline $\mathbf{6}$ & Gaîté & Contrescarpe \\
\hline $\mathbf{7}$ & Mabillon & Assomption \\
\hline $\mathbf{8}$ & Vilin & Saint-Honoré \\
\hline $\mathbf{9}$ & Italie & Jussieu \\
\hline $\mathbf{1 0}$ & Saint-Louis & Franklin \\
\hline $\mathbf{1 1}$ & Choiseul & Gaîté \\
\hline $\mathbf{1 2}$ & Contrescarpe & Junot \\
\hline
\end{tabular}

${ }^{326}[. .$.$] je décris 'ce que je vois' de la manière la plus neutre possible, j'énumère les magasins, quelques détails$ d'architecture, quelques micro-événements (une voiture de pompiers qui passe, une dame qui attaché son chien avant d'entrer dans une charcuteries, un déménagement, des affiches, des gens, etc.). PEREC. Lettre à Maurice Nadeau. (1969). In: Je suis né, 2006, pp. 58-59.

${ }^{327}$ [...] n'importe où (chez moi, au café, au bureau) je décris le lieu de mémoire, j'évoque les souvenirs qui lui sont liés, les gens qu j’y ai connus, etc. Ibidem, p. 59. 
ditados de alguma maneira pela realidade.” ${ }^{328}$ Já, com os textos das descrições de memória, tudo se passa de outra maneira: o autor, quando vai escrevê-las, parte do nada - o local está ausente - e ele deve se concentrar bastante para encontrar algo na memória que valha a pena registrar. Mesmo que Perec, ao descrever o projeto de Lieux, tivesse apresentado de maneira tão simples o que pretendia registrar como lembranças, Lejeune, ao ler o que Perec escreveu, constatou um resultado muito diferente: para dar saída ao processo de rememoração, Perec começava por tratar de algo relacionado ao seu presente para depois se esforçar em direcionálo ao lugar definido como o foco da lembrança. O resultado disso é que esses textos contêm muitas divagações e poucas vezes abordam de maneira específica algo relacionado propriamente ao lugar que deveria ser o foco da lembrança. Se isso nunca ocorria com os textos feitos in situ, os textos das lembranças acabam por criar uma grande expectativa. Como o escritor não se lembrava e não podia consultar o que tinha escrito sobre aquele mesmo local em outras ocasiões (os textos anteriores estavam todos lacrados em envelopes), as lembranças que anotava tanto podiam resultar em repetições maçantes quanto em surpresas reveladoras, como comenta Lejeune:

Nunca sabemos se vamos ler um texto estruturado ou uma sequência rapsódica. Voltar a uma zona já explorada ou descobrir algo novo. Mergulhar no passado ou ser testemunha de crises do presente. E, sobretudo, cada "lembrança" aparece como um pedaço de um gigantesco quebra-cabeça - com a diferença que esses pedaços não foram produzidos pelo recorte de um modelo preexistente, e que eles não foram feitos para serem realmente agrupados... ${ }^{329}$

Outra característica relevante desses textos é a ideia de imediatismo e neutralidade da escrita de Perec para esse projeto. Mesmo que seus textos fossem passados a limpo antes de serem guardados nos envelopes e lacrados, Lejeune entende que o conteúdo da escrita foi preservado $^{330}$ e vê ali: "uma escrita do primeiro jato. Uma escrita, que acabou de sair da caneta ou da máquina de escrever, fixada, fetichizada, registrada como sinal do instante que a

\footnotetext{
${ }^{328}$ On est sur les lieux, on a une chose précise à faire; la matière à traiter [...] est sous vos yeux; le début et la fin du texte, son ordre, sont dictés en quelque sorte par la réalité. LEJEUNE. La mémoire et l'oblique, 1991, p. 190.

${ }^{329}$ On ne sait jamais si l'on va lire un texte structuré ou une suite rapsodique. Revenir dans une zone déjà explorée ou découvrir du nouveau. Plonger dans le passé ou être témoin des crises du présent. Et surtout chaque "souvenir" apparaît comme un morceau d'un gigantesque puzzle - à cette différence près que ces morceaux n'ont pas été produits par découpage d'un modèle préexistant, et qu'ils ne sont pas vraiment faits pour être assemblés... Ibidem, p. 192.

${ }^{330}$ Lejeune pôde comparar os rascunhos feitos in situ com as folhas passadas a limpo e guardadas nos envelopes, reconhecendo como maior diferença apenas uma clareza maior do que havia sido escrito, sem qualquer intenção de estabelecer relações ou de ampliar o sentido do que havia sido anotado.
} 
produziu, intocável, lacrada à cera. Documento, traço, relíquia...". ${ }^{331}$ Esse material coletado, segundo o mesmo Lejeune, é indicador de uma transposição do trabalho literário: como não há qualquer trabalho de elaboração estilística, o exercício do escritor deveria se voltar para o futuro quando, após a conclusão da fase de coleta, ele passaria a pensar numa maneira de (re)compor todos os textos.

Talvez em algum momento, essa escrita mínima possa ter parecido insuficiente como base para um trabalho futuro. $\mathrm{O}$ fato é que, além de passar a coletar todo tipo de impresso que recolhia/recebia nesses locais, Perec decidiu incorporar às descrições in situ, feitas entre 1970 e 1971, o trabalho de alguns fotógrafos que passaram a acompanhar suas visitas. A ideia parece ter sido estabelecer uma confrontação dupla: da escrita com a fotografia e entre as próprias fotografias ao longo dos anos. Os locais fotografados foram apenas seis: a rue Vilin (junho de 1970), a rue de la Gaîté, a avenue Junot, a rue de l'Assomption, a rue Saint-Honoré (entre setembro e dezembro de 1970) e, por fim, a île Saint-Louis (março de 1971).

Se nas apresentações públicas do projeto de Lieux, Perec parecia encontrar alguma diversão, o trabalho que ele tinha em ir aos lugares para descrevê-los in situ, e a necessidade de permanecer em Paris pelo menos um dia ao mês, todos os meses do ano, passaram a preocupá-lo. Segundo Lejeune, conforme o projeto avançava, Perec foi deixando de acompanhar o que ele havia estabelecido na contrainte inicial com as combinações de descrições. Ele passou a escrever os textos em meses diferentes daqueles pré-estabelecidos e a escrever vários deles num único mês para não atrasar mais ainda o projeto. As descrições feitas in situ foram ficando cada vez mais breves e silenciosas. Entre 1973 e 1974 Perec abandonou o projeto por 18 meses para se dedicar à filmagem de Un homme qui dort [Um homem que dorme] - trabalho de codireção do filme, feito a partir de seu livro homônimo publicado em 1967.

Talvez a maior surpresa para o leitor de Perec ao ler o estudo de Lejeune sobre Lieux seja a confirmação de que essa obra tem sua origem em uma desilusão amorosa, em um momento de abalo emocional. Lejeune encontra essa justificativa no texto $n^{o} 41$, que corresponde à lembrança da Île Saint-Louis (cf. Tabelas 1 e 2) - texto que devia ter sido escrito em setembro de 1970, mas que só foi escrito em 02 de outubro:

\footnotetext{
${ }^{331}[\ldots]$ une écriture du premier jet. Une écriture, à peine sortie de la plume ou de la machine, fixée, fétichisée, enregistrée comme signe de l'instant qui l'a produite, intouchable, cachetée à la cire. Document, trace, relique... LEJEUNE. La mémoire et l'oblique, 1991, p. 145.
} 
Eu devo evidentemente indicar que a escolha da ilha Saint-Louis entre esses doze lugares foi determinada (da mesma maneira que a concepção geral do livro) por causa da minha ruptura com S. ${ }^{332}$ em janeiro de 1969: era, ao mesmo tempo, encontrar alguma coisa para fazer, e me enraizar em Paris. [...] Passando uma vez por ano na ilha, talvez eu a reencontraria, em um ano, em cinco; o tempo terá passado, nós trocaremos algumas palavras; iremos tomar um café num bar, teremos esquecido nossas reclamações e compreendido que nós nos amávamos etc., etc. é, aliás, o que aconteceu, salvo que eu não me servi (não tive tempo) do pretexto dos "lugares". De todo modo, evocar cada ano minhas lembranças sobre a ilha, ruminar, não esquecer...

Eu não quero esquecer. Talvez seja o núcleo desse livro; guardar intacto, repetir cada ano as mesmas lembranças, evocar as mesmas imagens, os mesmos acontecimentos minúsculos, ajuntar tudo numa memória soberana, demencial. ${ }^{333}$

'Continuar a remoer as mesmas imagens', 'guardar intactas certas lembranças', talvez tenha sido exatamente isso que Perec preferiu fazer ao abandonar o projeto e deixar todas as lembranças lacradas em seus envelopes. As lembranças às quais ele daria voz seriam outras: a que está no centro de $W$ - a única lembrança possível para uma infância fraturada pela guerra , e as lembranças comuns da idade adulta presentes em Je me souviens. Lejeune ${ }^{334}$ reconhece que poderia acontecer com Lieux o mesmo que aconteceu com La disparition: uma complementaridade entre a contrainte (o jogo da linguagem) e o trabalho de luto (o fundo autobiográfico). Mas a contrainte em Lieux não foi forte o suficiente para fazer o escritor levar adiante o trabalho com a linguagem, ela também estava apoiada na vida...

É possível que nas lembranças guardadas em envelopes, cheias de segredos incômodos, a voz feminina que ressoasse não fosse dada a diálogos instigantes e questionadores. Lejeune encontra no mesmo envelope onde estava o texto $n^{\circ} 41$, um pequeno envelope com o título: Supplément inutile pour servir à l'histoire de ma vie [Suplemento inútil para servir à história da minha vida] e que contém um texto onde no final está escrito:

332 'S' é Suzanne Lipinska, proprietária do Moulin d'Andé, um velho moinho na região da Basse-Normandie, que recebia artistas, escritores e cineastas como um espaço de retiro e trabalho nos anos sessenta e setenta. Perec frequentou esse espaço entre 1966 e 1970. No início ele ia aos fins de semana ou sempre que podia se distanciar do trabalho no C.N.R.S. Quando Suzanne vinha a Paris, ficava hospedada em algum lugar da île Saint-Louis no centro de Paris. Cf. BELLOS. Georges Perec, 1994, pp. 354-357.

${ }^{333}$ Je dois évidemment noter que le choix de l'île Saint-Louis parmi ces douze lieux fut déterminé (de même que la conception générale du livre) par ma rupture avec S. en janvier 1969: c'était à la fois trouver quelque chose à faire, et m'enraciner à Paris. [...] En passant une fois par an dans l'île, peut-être la rencontrerai-je, dans un an, dans cinq ans; du temps aura passé, nous échangerons quelques mots; nous irons boire un café dans un café, nous aurons oublié nos griefs, compris que nous nous aimions, etc., etc. c'est d'ailleurs ce qui s'est passé, sauf que je ne me suis pas servi (pas eu le temps) du prétexte des "lieux”. De toute façon, évoquer chaque année mes souvenirs sur l'île, ressasser, ne pas oublier...

Je ne veux pas oublier. Peut-être est-ce le noyau de tout ce livre: garder intact, répéter chaque année les mêmes souvenirs, évoquer les mêmes visages, les mêmes minuscules événements, rassembler tout dans une mémoire souveraine, démentielle. PEREC apud LEJEUNE. La mémoire et l'oblique, 1991, p. 159.

${ }^{334}$ Ibidem, p. 158. 
"Eu não sei o que fazer, objetivamente: procurar ainda uma vez a alma gêmea (a alma mãe, para ser mais preciso) a protetora, o colo." 335

A dona da obra que apresento a seguir não trouxe qualquer consolo à vida pessoal do escritor, mas sua obra lhe apresentaria uma maneira nova de encarar o cotidiano, as coisas e a escrita, mesmo que isso se referisse a uma 'vida vivida' nove séculos antes.

\subsubsection{O verdadeiro realismo, ou, as lições de uma dama do século XI}

Sei Shônagon não classifica; ela enumera e recomeça. Um tema provoca uma lista, de simples enunciados ou de anedotas. Mais à frente, um tema quase idêntico produzirá outra lista, e assim sucessivamente; chega-se assim a séries que se pode reunir; por exemplo, as "coisas" emocionantes (coisas que fazem o coração bater, coisas que se escuta às vezes com mais emoção do que o costume, coisas que emocionam profundamente) ou ainda, na série de "coisas" desagradáveis:

Coisas desoladoras

Coisas detestáveis

Coisas contrariantes [...]. ${ }^{336}$

Georges Perec

Assim que publica Je me souviens (Les choses communes I) (1978), Georges Perec ${ }^{337}$ foi questionado sobre quais seriam suas próximas 'coisas comuns' a serem publicadas, e ele especificou: Lieux où j'ai dormi - Les choses communes $2{ }^{338}$ [Lugares onde dormi - As coisas comuns 2]; Notes de chevet - Les choses communes $3^{339}$ [Notas de cabeceira - As

335 "Je ne sais pas quoi faire, objectivement: chercher encore une fois l'âme soeur (l'âme mère plutôt) la protectrice, le giron”. LEJEUNE. La mémoire et l'oblique, 1991, p. 159.

${ }^{336}$ Sei Shônagon ne classe pas; elle énumère et recommence. Un thème provoque une liste, de simples énoncés ou d'anecdotes. Plus loin, un thème presque identique produira une autre liste, et ainsi de suite; on aboutit ainsi à des séries que l'on peut regrouper; par exemple les "choses” émouvantes (choses qui font battre le cour, choses que l'on entend parfois avec plus d'émotion qu'à l'ordinaire, choses qui émeuvent profondément) ou bien, dans la série de "choses" désagréables: / Choses désolantes / Choses détestables / Choses contrariantes [...]. PEREC. "Penser/Classer”. (1982). In: . Penser / Classer, 2003c, p. 163.

337 PEREC. Ce qu'il se passe quand il ne se passe rien. (1978). In: pp. 215-216. . Entretiens et Conférences, 2003a,

${ }^{338}$ Este é um dos vários projetos de escrita que Perec definiu muito cedo em sua carreira, citou várias vezes em entrevistas e cartas, mas que desenvolveu muito pouco. Com a descrição minuciosa dos quartos onde havia dormido, o autor pretendia compor "um tipo de autobiografia vesperal". Como referências para essa obra, ele pensava nos primeiros parágrafos da Recherche du temps perdu [Em busca do tempo perdido] de Proust, e em Nuits sans nuits [Noites sem noites], de Leiris. Perec trata desse projeto de escrita em mais detalhes no capítulo La chambre [O quarto] no livro Espèces d'espaces. O único material publicado referente a esse projeto se resume a três textos curtos. Cf. PEREC. Trois chambres retrouvées. (1977). In: Penser / Classer, 2003c, pp. 25-29.

${ }^{339}$ Perec pensava escrever um livro à maneira de Sei Shônagon. Além de notas esparsas, o único desdobramento direto desse projeto inicial é o texto: Notes brèves sur l'art et la manière de ranger ses livres [Notas breves sobre a arte e a maneira de arrumar seus livros]. Cf. PEREC. Notes brèves sur l'art et la manière de ranger ses livres. (1978). In: Penser / Classer, 2003c, pp. 31-42. 
coisas comuns 3]; e, por último, estaria Tentative de description de quelques lieux parisiens Les choses communes $4^{340}$ [Tentativa de descrição de alguns lugares parisienses - As coisas comuns 4]. Perec não completou nenhum desses projetos e, talvez por isso, as obras que serviam de base para a escrita dessa série acabaram não ganhando destaque. Esse é o caso de O livro de travesseiro de Sei Shônagon ${ }^{341}$.

Não encontrei qualquer referência sobre o momento que Perec teve o primeiro contato com essa obra, mas segundo informam Dominique Bertelli e Mireille Ribière ${ }^{342}$, ela era muito apreciada por dois autores do OuLiPo: François Le Lionnais e Raymond Queneau. Devido à maneira singular como foi escrita e ao caráter absolutamente atual do seu conteúdo para pensar/repensar várias das ideias sobre o cotidiano, é bem provável que a obra dessa autora também tivesse sido motivo do interesse dos colegas de Perec na revista Cause commune. De qualquer modo, o exercício de uma escrita neutra e fragmentária, uma base autobiográfica que mais esconde do que revela e um olhar sensível sobre o banal do cotidiano coletivo fazem de Notas de travesseiro a mais instigante obra perequiana avant la lettre.

'Sei Shônagon' é o pseudônimo de uma mulher que viveu aproximadamente entre os anos 966 e 1025 da era cristã, durante o Período Heian (794-1185), quando a corte se transferiu de Nara, a antiga capital para a nova: Quioto. Ela era uma dama da corte imperial que servia à imperatriz Teishi (ou Sadako). Nessa época os homens cultos não escreviam em sua língua nativa, mas numa forma particular de chinês que não acompanhava a oralidade. As mulheres, afastadas das atividades burocráticas do governo e sem ter acesso às mesmas condições de aprendizagem e cultura que a elite masculina, acabaram compondo uma literatura que registraria pela primeira vez o japonês tal como ele era falado, por meio de obras que abordavam o universo doméstico e o exercício das atividades cotidianas.

\footnotetext{
${ }^{340}$ Como já mencionei anteriormente, Perec deu esse título a cinco séries de descrições retiradas de Lieux e que ele publicou separadamente.

${ }^{341}$ Perec teve contato com pelo menos duas edições do livro de Sei Shônagon: a edição francesa, Notes de chevet. Trad. André Beaujard. Paris: Gallimard/UNESCO, 1969. (essa é uma edição revista da primeira tradução francesa feita em 1934); e a edição inglesa, The pillow book. Trad. Juan Morris. London: Penguin, 1971. Cf. Le catalogue de la bibliothèque de Georges Perec. Disponível em: <http://associationgeorgesperec.fr/spip.php?rubrique13>. Acesso em 18 set. 2011.

A edição consultada para esta pesquisa, e de onde foram tiradas todas as referências, é a edição brasileira: $\boldsymbol{O}$ livro de travesseiro. Trad. e Notas de Andrei S. Cunha, 2008. (As edições francesa e brasileira traduzem o título de maneira diversa e tratarei disso mais adiante).

${ }^{342}$ Cf. Nota 9. In: PEREC. Ce qu'il se passe quand il ne se passe rien. (1978). In: Conférences, 2003a, p. 216. 
No centro do livro de Sei Shônagon está, segundo Andrei dos Santos Cunha ${ }^{343}$ (tradutor dessa obra para o português), o conceito de ito wokashi - "aquilo que é belo, divertido, delicioso, elegante, sublime, de bom gosto", que se apresenta por meio de "uma sucessão de deslumbramentos estéticos e uma exaltação ao esplendor da vida na corte".

O livro inaugura o que depois configuraria um gênero: o sôshi ou zuihitsu - que significa 'notas esparsas', e “que tem por pressuposto uma ausência de plano ou desígnio por parte do autor, o qual vai anotando, literalmente 'ao correr do pincel', tudo o que lhe vem à mente ou que lhe evoca a fantasia de escrever". ${ }^{344}$ Essa maneira de escrever não pode ser tida como um diário pois não acompanha qualquer cronologia ou periodicidade, não apresentando uma estrutura formal que ordene e estabeleça relações entre suas partes. Todas essas características estariam na origem de outra forma literária importante surgida no Japão já no século XX: o "romance de mim mesmo" [watakushi-shôsetsu $]^{345}$.

Quanto ao 'livro de travesseiro' mencionado no título, Cunha cita Morris ${ }^{346}$, para explicar que se trata de um caderno ou de um conjunto de folhas soltas, mantido num ambiente privado e utilizado para fazer anotações, escrever poemas, registrar todo tipo de acontecimento relacionado à privacidade e às atividades/objetos/espaços do cotidiano ${ }^{347}$. Se já não fosse pelo conteúdo e pela forma de sua obra, a ideia desse caderno que mantém com sua autora uma relação de proximidade física tão intensa já seria, por princípio, algo altamente atrativo para Perec, um amante de cadernos que fez uso deles para as anotações de várias de suas obras.

A obra de Sei Shônagon é composta por uma série numerada de duzentas e oitenta e seis seções, todas elas com títulos e compostas por listas, relatos de experiências pessoais, cenas imaginadas e comentários diversos. Quanto às listas, elas tanto podem abordar um tema específico como, por exemplo:

\footnotetext{
${ }^{343}$ CUNHA. Notas do tradutor. In: SHÔNAGON. O livro de travesseiro, 2008, p. 10.

${ }^{344}$ Ibidem, p. 11.

${ }^{345}$ Ibidem, p. 12.
}

${ }^{346}$ MORRIS, Ivan. The world of the shining prince. New York: Penquin, 1964, p. 376. Apud CUNHA. Op. cit., p. 13.

${ }^{347}$ Se a tradução francesa optou por traduzir o título da obra como Notas de cabeceira, (com o sentido de 'livro de cabeceira'), o tradutor brasileiro optou por $O$ livro de travesseiro e sua justificativa é bem simples: um livro de cabeceira é um livro que se lê - sendo essa também uma forma para designar um livro preferido. $\mathrm{O}$ 'livro' a que a obra de Sei Shônagon faz menção não era para ser lido, mas escrito, como um diário, ou caderno de anotações. Além disso, o tradutor optou por usar a palavra 'travesseiro', ao invés de 'cabeceira', porque no Japão do século $\mathrm{X}$, o travesseiro era um objeto de madeira forrada sobre a qual as mulheres apoiavam a cabeça para dormir sem danificar seus penteados. Esses 'travesseiros' possuíam muitas vezes gavetinhas e era ali onde se guardava papel, pincel e tinta. Cf. CUNHA. Op. cit., pp. 12-13. 


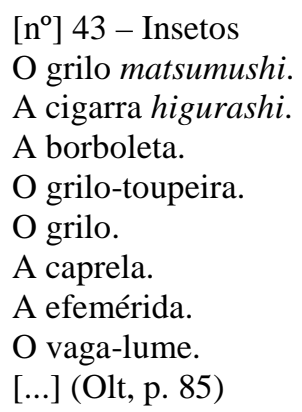

como podem agrupar elementos díspares - apresentados por uma única palavra ou por relatos longos e/ou breves - designados como 'coisas' [mono (em japonês)]. De todas as seções do livro, sessenta e nove delas tratam de 'coisas' e estão circunstanciadas em função de sentimentos, impressões e avaliações de todo tipo (cf. Lista 1), como, por exemplo:

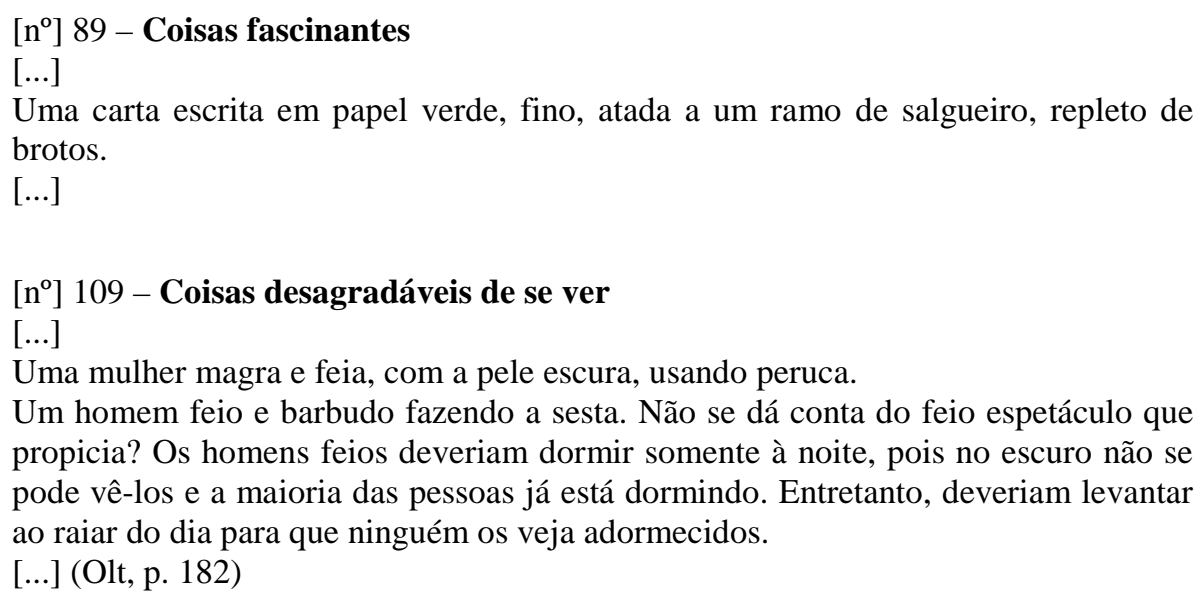

e ainda:

$\left[\mathrm{n}^{\circ}\right] 252$ - Coisas que passam

Um barco de velas içadas.

A idade das pessoas.

A primavera, o verão, o outono e o inverno. (Olt, p. 308)

É característica da escrita de Sei Shônagon a maneira como ela expõe suas descobertas e observações: sempre no interior de unidades autônomas e sem qualquer cronologia e/ou hierarquia (os números das seções parecem indicar apenas uma sequência), como se ela tomasse do vivido um fragmento que ela simplesmente cola em seu caderno. Além disso, como salienta Andrei Cunha ${ }^{348}$, há o aspecto de incompletude daquilo que é exposto - o que poderia ser atribuído ao fato de que, para Shônagon, o ato de escrever seria algo que acompanhava a própria vida, tirando dali tanto seu assunto como seu impulso. É por isso que

${ }^{348}$ CUNHA. Notas do tradutor. In: SHÔNAGON. O livro de travesseiro, 2008, p. 17. 
a seção final do livro: assertiva, explicativa e conclusiva, destoa tanto do resto do livro tomado pelo fragmentário, pela fugacidade e pelo imediatismo ${ }^{349}$.

É assim que a sua escrita, fixada no contexto das atividades cotidianas e apresentada em partes, dá ao leitor a liberdade para iniciar/retomar sua leitura em qualquer ponto, espelhando o que ocorre com os encontros/desencontros/reencontros de um cotidiano banal em que nossa atenção sempre pode ser atraída por aquilo que sempre esteve ali, mas que nunca se fez notar. Todos esses elementos fazem pensar no que Roland Barthes escreve em Efeito de real ${ }^{350}$ e ajudam a entender tanto o fascínio de Perec pela escrita dessa autora quanto pela maneira como ele - e Édouard Levé também, mais adiante - relacionaria sua escrita ao 'vivido'.

Roland Barthes, no texto citado acima, faz uma reflexão sobre a importância do desimportante na narrativa contemporânea explicando que na cultura ocidental a descrição havia surgido com o intuito de promover uma finalidade estética da linguagem (a expressão do belo) ${ }^{351}$, não estando submetida a nenhum realismo exterior ao texto já que o verossímil ali não era referencial, mas discursivo: "são as regras genéricas do discurso que impõem a lei”, escreve Barthes ${ }^{352}$. Assim, qualquer uso da linguagem que buscasse simplesmente denotar o que Barthes chama de “'real concreto' (pequenos gestos, atitudes transitórias, objetos insignificantes, palavras redundantes)", configuraria uma resistência ao sentido: "uma oposição mítica do vivido e do inteligível" ${ }^{353}$. Mas esse mesmo 'real concreto' era referência essencial para a narrativa histórica, onde se buscava relatar aquilo que realmente havia se passado. Até esse momento a distinção era clara: o verossímil é da ordem do opiniável - está sempre submetido à opinião do público e faz parte de um conhecimento que é compartilhável; já, a notação do real depende de evidências e é sempre fragmentária, particular. Com o realismo moderno surge uma ruptura entre esses dois tipos de narrativa, dando vez ao que Barthes chama de 'um novo verossímil', ou seja, "qualquer discurso que aceite enunciações

\footnotetext{
${ }^{349}$ Andrei Cunha chega a indicar que há suspeitas que o final desse livro seja apócrifo. Cf. CUNHA. Nota 14 (Notas Bibliográficas). In: SHÔNAGON. O livro de travesseiro, 2008, p. 358.

${ }^{350}$ BARTHES. O Efeito de real. (1968). In: BARTHES et al.. Literatura e realidade, 1984, pp. 87-97.

${ }^{351}$ Expressão maior disso é a ekphrasis, figura retórica que permitia a seu autor compor pequenas descrições destacáveis, que poderiam ser transferidas para diferentes contextos e que tinham como finalidade a descrição de lugares, pessoas, obras de arte etc. Segundo Barthes, com a ekphrasis surgia uma nova unidade sintagmática, o fragmento [le morceau], que podia deixar o discurso da oratória para se integrar à narrativa. Essa seria então a forma mais antiga de 'colagem' no interior da linguagem verbal. Ibidem, p. 90. / Cf. BARTHES. L’ancienne rhétorique. In: Communications, nº 16, 1970, pp. 183-187.

352 BARTHES. O Efeito de Real. Op. cit., p. 90.

${ }^{353}$ Ibidem, p. 93.
} 
creditadas apenas pelo referente" ${ }^{354}$. Nesse realismo, o verossímil continua trabalhando com os mesmos pressupostos da narrativa ficcional, incorporando também um pormenor concreto que pressupõe um vínculo direto entre um referente e um significante. Sem significado, o que prevalece ali é o referente, que se transforma no próprio significante do realismo.

A escrita de Sei Shônagon que seduzia Perec, numerada e fragmentária, composta por narrativas curtas, impressões e listas, abre mão de construir uma grande narrativa, se contentando em montar um arquivo de aspectos desimportantes do vivido - está aí o 'realismo' explicado por Barthes, mas concentrado quase que exclusivamente no pormenor concreto. Uma estrutura que se fixa no particularíssimo: lugares, personalidades, objetos, comportamentos e costumes, sem se preocupar exatamente com o sentido de tudo aquilo.

A obra de Sei Shônagon toca na obra de Perec em vários pontos e há entre elas uma complementaridade de alma-gêmea que se efetiva, primeiro pelo estranhamento que afasta essa escrita oriental antiga das formas cansadas da literatura ocidental, depois por haver ali a presença de uma voz feminina relacionada à casa, à cama, ao conforto, à contemplação, através de uma escrita que simplesmente registra e arruma o que se encontra ao redor por mãos muito delicadas, discretas e praticamente invisíveis. O resultado obtido por Perec, como ele menciona em uma entrevista, parece semelhante ao que fazia Sei Shônagon:

[...] há um período (que correspondia, aliás, a uma psicanálise) no qual eu tinha uma verdadeira fobia de esquecer. Eu publiquei em Ação Poética um texto que se chamava "Tentativa de enumeração de todos os alimentos líquidos e sólidos que eu engoli ao longo de um ano"! Eu mantinha um diário. Eu anotava minhas refeições e isso dava um resultado que era ao mesmo tempo monstruoso e completamente curioso. Era uma maneira completamente compulsiva! o medo de esquecer! Eu mantinha esse diário, eu anotava todos os acontecimentos, de maneira alguma meus pensamentos, não, apenas fatos do tipo "Eu comi uma perna de cordeiro e eu bebi uma garrafa de gigondas". ${ }^{355}$

Em Espèces d'espaces, Perec dedica um capítulo inteiro à cama e a compara a uma folha de papel. Para ele e Sei Shônagon a escrita está ligada à cama, à intimidade, ao recolhimento e ao medo de esquecer. Sobre sua relação com a cama, Perec escreve:

\footnotetext{
${ }^{354}$ BARTHES. O Efeito de Real. (1968). In: BARTHES et al.. Literatura e realidade, 1984, p. 95.

${ }^{355}$ [...] il y a un période (qui correspondait d'ailleurs à une psychanalyse) où j'avais une véritable phobie d'oublier. J'ai publié dans Action Poétique un texte qui s'appelait "Tentative d'énumération de tous les aliments liquides et solides que j'ai ingurgités au cours d'une année”! Je tenais un journal. Je notais mes repas et cela donne un résultat qui est à la fois monstrueux et tout à fait curieux. C'était une démarche tout à fait compulsive! la peur d'oublier! J'ai tenu ce journal, j'ai noté tous les événements, pas du tout des pensées, non, des faits du genre “J'ai mangé un gigot d'agneau et j'ai bu une bouteille de gigondas". VENAILLE. Le travail de la mémoire. (1979). In: PEREC. Je suis né, 2006, p. 87-88.
} 
"Eu gosto da minha cama. Eu gosto de ficar estendido na minha cama e olhar o teto com um olho plácido. Eu consagraria a ela com prazer o essencial do meu tempo [...] se ocupações reputadas mais urgentes [...] não me impedissem de fazê-lo com tanta frequência." 356 (Ee, p. 27).

Através da obra de Sei Shônagon é possível pensar a obra de Perec como um único e grande 'livro de travesseiro' - objeto biográfico que acompanha seus passos e olhares pela cidade e que perpetua o registro das coisas comuns: coisas vistas (através de relatos, listas, descrições), coisas imaginadas (através da ficção e da obra poética), coisas sonhadas (através dos seus projetos de escrita e de seus sonhos) e coisas lembradas (suas lembranças coletivas). A palavra dessa autora, preocupada em observar a vida ao seu redor e em nomear e registrar as minúcias e as banalidades do cotidiano, é professora de insignificâncias para Perec, órfão da guerra, vítima da História com 'H' maiúsculo. Por meio da obra de Sei Shônagon, Perec pôde se aproximar do que ele acreditava lhe ter sido tirado: a oportunidade de uma vida comum, com rotinas, tarefas, objetos e lugares banais, coisas que para ele haviam ficado no campo dos desejos, como nessa descrição de 'vida feliz' que Perec escreveu em $W$ (à maneira da introdução de Les choses):

Quanto a mim, eu teria gostado de ajudar minha mãe a limpar a mesa da cozinha
depois do jantar. Sobre a mesa teria havido uma toalha encerada com pequenos
quadrados azuis; sobre a mesa, teria havido uma luminária suspensa com uma
cúpula parecida com um prato, em porcelana branca ou em chapa esmaltada, e um
sistema de polias com um contrapeso em forma de pêra. Em seguida eu teria ido
procurar minha pasta, eu teria tirado meu livro, meus cadernos e meu estojo de
madeira, eu os teria colocado sobre a mesa e teria feito meus deveres. É dessa
maneira que isso se passava nos meus livros de escola. ${ }^{357}$ (W, p. 99 ).

Ao final dessa última citação, Perec trata com ironia do modelo institucional da vida comum, da normalidade saudável e do padrão a seguir presentes nos livros de escola. Já, em O livro de travesseiro, o ensinamento é de outra ordem e o maior ganho que essa obra pode ter trazido a Perec e a outros autores interessados em se aproximar do cotidiano banal, suas ações e obras, é a liberdade que a própria autora se concede ao desinvestir toda e qualquer importância sobre aquilo que escreve:

\footnotetext{
356 J'aime mon lit. J'aime rester étendu su mon lit et regarder le plafond d'un ail placide. J'y consacrerais volontiers l'essentiel de mon temps [...] si des occupations réputées plus urgentes [...] ne m'en empêchaient si souvent.

${ }^{357}$ Moi, j'aurais aimé aider ma mère à débarrasser la table de la cuisine après le dîner. Sur la table, il y aurait eu une toile cirée à petits carreaux bleus; au-dessus de la table, il y aurait eu une suspension avec un abatjour presque en forme d'assiette, en porcelaine blanche ou en tôle émaillée, et un système de poulies avec un contrepoids en forme de poire. Puis je serais allé chercher mon cartable, j'aurais sorti mon livre, mes cahiers et mon plumier de bois, je les aurais posés sur la table et j'aurais fait mes devoirs. C'est comme ça que ça se passait dans mes livres de classe.
} 


\section{$\left[n^{\circ}\right] 139$ - Coisas inúteis}

[...]

Maisena de arroz para engomar. Sei que é um assunto muito banal e que todos odiarão que eu o mencione. No entanto, faço-o do mesmo jeito. De fato, sinto-me em liberdade de incluir tudo nesta lista, até mesmo os atiçadores das fogueiras de despedida das almas. Afinal de contas, esses objetos existem em nosso mundo e todos os conhecem. Admito que não teria coragem de listá-los em um lugar onde pudessem ser vistos. Todavia, como nunca pensei que estas notas fossem lidas por alguém, exceto eu mesma, incluo nelas tudo o que acho que deva incluir, por mais estranho ou desagradável que seja.

[...] (Olt, pp. 213-214).

Esse é o conflito do exercício com o cotidiano: uma voz particular que se nivela a uma voz coletiva para dizer o que todo mundo sabe agora, sabia antes e continuará sabendo depois - quer essa voz particular se manifeste ou não. É por essa indicação que a autora se aproxima do comum e confirma outra ideia de Blanchot ${ }^{358}$ sobre o cotidiano:

O cotidiano em que vivemos como que fora do verdadeiro e do falso é um nível de vida em que o que reina é a recusa de ser diferente, a animação ainda indeterminada, sem responsabilidade e sem autoridade, sem direção e sem decisão, uma reserva de anarquia, já que repele todo começo e rejeita todo fim. É o cotidiano.

Quando Perec foi perguntado por Frank Venaille ${ }^{359}$ se ele seria um autor realista, já que aceitava submeter sua escrita ao vivido, Perec respondeu que sim e completou dizendo que, ao buscar relacionar a autobiografia com o vivido, ele preferia não abordar aquilo que pensava, por exemplo, preferindo descrever de forma minuciosa o que comia, vestia, sonhava - dando a ver o 'vivido' por aquilo que seria compartilhável e que ele identificava com o já citado 'barulho de fundo'. Para contar de maneira enviesada sua própria história - já que acreditava não ser possível contá-la de maneira objetiva -, Perec se apoiou nas coisas e buscou uma orientação particular:

Meu mestre nesse domínio é uma japonesa. Sei Shônagon, que escreveu Notes de
chevet, uma coletânea de pensamentos sobre absolutamente nada, enfim! sobre
as cascatas, as roupas, as coisas que dão prazer, as coisas que tem uma graça
refinada, as coisas sem valor etc. Para mim está aí o verdadeiro realismo: se
apoiar sobre uma descrição da realidade desvinculada de todas as suposições.

${ }^{358}$ BLANCHOT. A fala cotidiana. In: A conversa infinita, 2007, p. 242.

${ }^{359}$ VENAILLE. Le travail de la mémoire. (1979). In: PEREC. Je suis né, 2006, p. 90.

${ }^{360}$ Mon maître dans ce domaine c'est une Japonaise. Sei Shônagon, qui a écrit Notes de chevet, un recueil de pensées sur rien du tout, enfin! sur les cascades, les vêtements, les choses qui font plaisir, les choses qui ont une grâce raffinée, les choses sans valeur, etc. Pour moi c'est cela le véritable réalisme: s'appuyer sur une description de la réalité débarrassée de toutes présomptions. Ibidem, p. 89. 
Dessa forma, com a atenção voltada diretamente para as coisas - sem contexto, sem vínculos, sem hereditariedade, sem explicações ou justificativas - e talvez sem que soubesse exatamente, o interesse de Perec pela obra de Sei Shônagon o aproximava do que Alain Robbe-Grillet, em 1956, havia previsto como Une voie pour le roman futur [Um caminho para o romance futuro]:

No lugar desse universo de "significações" (psicológicas, sociais, funcionais), seria
necessário, portanto tentar construir um mundo mais sólido, mais imediato. Que seja
de início pela presença que os objetos e os gestos se imponham, e que essa presença
continue, a seguir, a dominar, acima de toda teoria explicativa que tentasse
enclausurá-los em um sistema qualquer de referência, sentimental, sociológico,
freudiano, metafísico ou outro.
Nas construções romanescas futuras, gestos e objetos estarão ali antes de ser alguma
coisa; e ainda estarão ali depois, duros, inalteráveis, presentes para sempre e como
que caçoando de seus próprios sentidos [...]. ${ }^{361}$

A escrita direta e simples dessa autora e, principalmente, seu prazer em afirmar uma vontade (teimosia) em se satisfazer com tão pouco podem ter sido os maiores atrativos nessa longa lista de coisas presentes na obra de Sei Shônagon (cf. Lista 1) ${ }^{362}$, pois é por elas que a autora fala de si, dos outros, do seu meio e do seu tempo. Enquanto Perec se aproximava dessa obra e configurava pela escrita sua aproximação do banal, alguns artistas plásticos, inquietos e questionadores, pouco idealistas e muito interessados no compartilhamento do que se vive, também se voltavam para o que lhes era próximo, imediato e comum. Para tanto, muitos deles tomaram a fotografia como meio de lidar com o que era simples evidência, banalidade e repetição, compondo o que André Rouillé ${ }^{363}$ e Paul Ardenne ${ }^{364}$ chamaram de "un art du presque-rien" [uma arte do quase-nada]: expressão que trocava a singularidade do extraordinário pela mesmice do infraordinário.

${ }^{361}$ A la place de cet univers des "significations" (psychologiques, sociales, fonctionnelles), il faudrait donc essayer de construire un monde plus solide, plus immédiat. Que ce soit d'abord par leur présence que les objets et les gestes d'imposent, et que cette présence continue ensuite à dominer, par-dessus toute théorie explicative qui tenterait de les enfermer dans un quelconque système de référence, sentimental, sociologique, freudien, métaphysique, ou autre.

Dans les constructions romanesques futures, gestes et objets seront là avant d'être quelque chose; et ils seront encore là après, durs, inaltérables, présents pour toujours et comme se moquant de leur propre sens [...]. ROBBE-GRILLET. Une voie pour le roman futur. (1956). In: Pour un Nouveau Roman, 2006, p. 20.

${ }^{362}$ Compus essa lista copiando simplesmente os títulos das seções que tratam de 'coisas' no livro de Sei Shônagon.

${ }^{363}$ ROUILLÉ. Des grands aux petits récits. In: La photographie, 2006, p. 482.

${ }^{364}$ ARDENNE. Low as high. Un art du presque rien. In: Art. L’Âge Contemporain, 2003, pp. 312350. 
Coisas desoladoras

Coisas de que se cansa ao fim

Coisas desprezíveis

Coisas detestáveis

Coisas que fazem o coração bater mais rápido

Coisas que dão saudade do passado

Coisas que alegram o coração

Coisas elegantes

Coisas que não combinam

Coisas que causam insegurança

Coisas que não podem ser comparadas

Coisas difíceis de ver

Coisas que são uma perda de tempo

Coisas de aparência agradável

Coisas que causam uma impressão triste

Coisas maravilhosas

Coisas fascinantes

Coisas que nos deixam de mau humor

Coisas que nos envergonham

Coisas que nos causam mal-estar

Coisas lamentáveis

107 Coisas que parecem intermináveis

109 Coisas desagradáveis de se ver

110 Coisas embaraçosas

115 Coisas que de vez em quando nos emocionam mais do que de costume

116 Coisas que pioram ao ser pintadas

117 Coisas que melhoram a (sic) ser pintadas

119 Coisas que nos emocionam

122 Coisas que nos fazem sentir compaixão

123 Coisas que, só de ver, dão calor

125 Coisas sem valor

137 Coisas tediosas

138 Coisas que enganam o tédio

139 Coisas inúteis

140 As coisas mais maravilhosas do mundo

145 Coisas muito feias

146 Coisas de aspecto limpo

147 Coisas ordinárias

148 Coisas angustiantes

149 Coisas meigas

150 Coisas incontroláveis

151 Coisas cujo nome é assustador

152 Coisas comuns que se tornam impressionantes se escritas em chinês

153 Coisas que parecem sujas

154 Coisas comuns que se tornam importantes em ocasiões específicas

155 Coisas que afligem

156 Coisas que provocam inveja

157 Coisas que não se agüenta esperar

158 Coisas que provocam impaciência

161 Coisas que já não servem mais, mas lembram o passado

162 Coisas em que não se pode confiar

164 Coisas distantes, ainda que próximas

165 Coisas próximas, ainda que distantes

195 Coisas encantadoras

212 Coisas para se ver

226 Coisas que são boas quando são grandes

227 Coisas que devem ser curtas

228 Coisas que cabe haver em uma casa

242 Coisas que caem do céu

248 Coisas turbulentas

249 Coisas descuidadas

252 Coisas que passam

253 Coisas que se ignora com frequência

254 Coisas sem asseio

255 Coisas apavorantes

256 Coisas que dão confiança

258 Entre as coisas mais tristes dos mundo

265 Coisas agradáveis

277 Coisas em que não se pode fiar

Lista 1 - As seções que tratam de 'coisas' em $\boldsymbol{O}$ livro de travesseiro de Sei Shônagon. 


\title{
3.2. Uma arte do desimportante
}

\begin{abstract}
O cotidiano e o ordinário constituem uma das problemáticas maiores da artefotografia nessa combinação, a fotografia, por natureza em contato direto com o mundo, terá contribuído a ancorar a arte no cotidiano, no banal, no familiar, no ordinário, na realidade a mais bruta. [...] as obras abordam zonas do real antes largamente excluídas da arte, por causa da sua grande trivialidade, sua banalidade inaceitável ou sua familiaridade indigna. ${ }^{365}$
\end{abstract}

André Rouillé

Segundo Paul Ardenne, ao longo do século XX a arte foi perdendo seu caráter sério e transcendental por meio de, basicamente, três objeções: a provocada pelo ready-made de Duchamp, que introduzia o objeto industrial banal no mundo da estética; a gerada pela Arte Pop, pelo neodadaísmo e pelo Fluxus que aproximavam e conferiam legitimidade, tanto ao que era muito elaborado e requintado, quanto ao que era simples e improvisado; e, a partir dos anos oitenta, a aceitação do kitsch como forma de arte, entendido por Ardenne como "essa apologia do não-estilo, esse extraordinário do ordinário formando o imaginário do indivíduo desindividualizado das sociedades de massa" 366 .

A essas três objeções, Ardenne acrescenta mais uma que é a síntese delas: é a descrença de que a arte seja algo importante. Surge daí uma arte que se projeta como simples, que parte de constatações e experiências do cotidiano banal e que busca materiais, formas e estratégias para se realizar mantendo o mesmo estatuto que a originou: a simplicidade.

Se a Arte Moderna havia se interessado pelo banal e se dedicado a se tornar popular, ela nunca deixou de enfatizar a singularidade do artista e de sua obra: ainda que o resultado final parecesse banal, a obra, na verdade, era de uma grande complexidade estética, fruto do grande conhecimento técnico e sensível do seu criador - que nunca era qualquer um. $\mathrm{O}$ que vai ocorrer no final do século XX é que o exercício da banalidade vem para marcar uma posição transgressora desse código: não bastava mais parecer banal, o artista e tudo o que ele fazia também teria que ser banal. Para isso, esses artistas não só tratavam de temas e

\footnotetext{
${ }^{365}$ Le quotidien et l'ordinaire constituent l'une des problématiques majeures de l'art-photographie dans cet alliage, la photographie, par nature en contact direct avec le monde, aura contribué à ancrer l'art dans le quotidien, le banal, le familier, l'ordinaire, dans la réalité la plus brute. [...] les ouvres abordent des zones du réel auparavant largement exclues de l'art, à cause de leur trop grande trivialité, de leur inacceptable banalité ou de leur indigne familiarité. ROUILLÉ. L'ordinaire, le dérisoire. In: 2006, p. 560. La photographie,

${ }^{366}$ [Le kitsch] cette apologie du non-style, cet extraordinaire de l'ordinaire formant l'imaginaire de l'individu désindividualisé des sociétés de masse. ARDENNE. Low as high. Un art du presque rien. In: L'Âge Contemporain, 2003, p. 313. Art.
} 
questionamentos do que é simples, como também se aproximavam da linguagem empregada nessas situações, buscando estabelecer canais de comunicação direta e imediata com o maior número de pessoas através de recursos como a repetição, o lugar comum e o preconceito.

No exercício desses artistas com o banal, vários deles decidem se integrar ao banal pela via do desimportante, apresentando como obra final o resultado dessa experiência. A dificuldade encontrada por esses artistas é que há aí um paradoxo que Ardenne resume assim:

[...] quanto mais próximo se está dela [da banalidade], mais longe se está dela. O ordinário, o banal, o toda-a-gente, é muito conhecido, a gente não os vê. Para ver o ordinário, é necessário apontá-lo, pô-lo em destaque - breve, torná-lo extraordinário. A banalidade só se pensa pela comparação, em função de oposições. Longe de surgir dela mesma, ela só é reconhecível uma vez que foi reconhecida, uma vez o universo restituído na sua normalidade desconcertante. ${ }^{367}$

Ardenne também aponta como marcante nessa expressão do banal, o fato desses artistas, além de trabalharem o exercício da taxonomia e do gesto comum, materializarem frequentemente suas obras diretamente no espaço coletivo - principalmente na rua - o lugar por excelência do comum compartilhado, do anonimato, das ações repetitivas e do encontro. Ainda que haja uma grande diversidade nas iniciativas de aproximação com o real, segundo esse mesmo autor, o que as torna semelhantes é o fato delas se voltarem para o mundo tal como ele é, sem outra verdade além daquela dada pela constatação imediata dos fatos. Por tudo isso, Ardenne ${ }^{368}$ vê aí um 'coisismo', uma arte movida pelas coisas e que também coisifica a arte - tudo agora se passa no real. O banal que interessa ao artista contemporâneo não visa valorizar a banalidade, mas tratar o banal enquanto tal.

É nesse universo que a fotografia passa a ser usada, não como uma técnica com uma história particular e com poéticas consagradas e repletas de refinamentos formais, mas como um procedimento/material/suporte a serviço de uma concepção artística e como um meio ágil, fácil, barato e popular de produzir imagens do real imediato: é o que André Rouillé 369 denomina de 'art-photographie' [arte-fotografia] - que é uma prática artística antes de ser fotográfica, em oposição à 'art des photographes' [arte dos fotógrafos]. A partir dos anos 90, mais do que ocorria antes, a fotografia se volta para o registro da banalidade e do

\footnotetext{
${ }^{367}[$ [...] le plus proche y est le plus lointain. L'ordinaire, le banal, le tout-venant, c'est bien connu, on ne les voit pas. Pour voir l'ordinaire, il faut le pointer, le mettre en exergue - bref, le rendre extraordinaire. La banalité ne se pense que dans la comparaison, en fonction d'oppositions. Loin de surgir d'elle-même, elle n'est repérable qu'une fois repérée, une fois l'univers redonné dans sa confondante normalité. ARDENNE. Low as high. Un art du presque rien. In: Art. L'Âge Contemporain, 2003, p. 320.

${ }^{368}$ Ibidem, p. 324.

${ }^{369}$ ROUILLÉ. La photographie, 2006, p. 449.
} 
desimportante. Esses não são temas exclusivos do campo fotográfico e perpassavam todas as modalidades artísticas que compõe a Arte Contemporânea. Segundo Dominique Baqué ${ }^{370}$, sucedendo ao pós-modernismo dominante dos anos oitenta e à ênfase dada ao luxo, à ficção e à ilusão, a arte do banal passava a ser usada para se contrapor à espetacularização das imagens e ao simulacro, e assim reivindicar a experiência do que é dado.

Fazendo uso de uma escrita fotográfica neutra, esses artistas do banal fotográfico buscaram constituir uma estética do ordinário e do mínimo fixada no cotidiano que, por meio de restrições, produz uma obra pouco assertiva que se move pelo campo da incerteza tanto do sentido e do assunto quanto da própria matéria da obra. Até o fazer da obra se apresenta como incerto já que, mesmo fazendo uso de fotografias, esses produtores não incorporam o rótulo de 'fotógrafos', dizendo que isso não corresponde ao que eles fazem, pensam e projetam.

Ao se afastar de qualquer subjetividade e se recusar a evocar uma narrativa, a arte do banal propõe ao observador o que Baqué ${ }^{371}$ chama de uma 'lição de coisas', um território ambíguo onde se lida com coisas - e não com objetos -, com gente - e não com indivíduos, e acrescento: com espaços - e não com lugares. Trabalhar com o banal é aceitar o universo do comum, do indistinto e do passageiro.

Em La passion du réel [A paixão do real], Catherine Francblin ${ }^{372}$ ressalta que quando os artistas do Nouveau Réalisme e da Arte Pop retiravam do mundo real o objeto utilizado pelas pessoas no dia a dia para incorporá-lo às suas obras, o que estava sendo apropriado pelos artistas era um real dos outros, um real do coletivo indistinto (como é exemplar na obra de Arman e de Brainard, por exemplo). Assim, no exercício de deixar o ateliê e se voltar para a cidade para colher a matéria de suas obras, os artistas do banal começavam a atuar de maneira semelhante ao que sempre haviam feito os fotógrafos, ou seja, compartilhando ainda que por uma fração de segundo - a mesma realidade das imagens registradas por seus aparelhos fotográficos, autorizando Barthes a escrever, em La chambre claire [A câmara clara], que "na fotografia jamais posso negar que a coisa esteve â̂" ${ }^{373}$. Dessa maneira, ao invés de pôr em prática o exercício do fazer, o artista do banal através da fotografia se dedicaria ao exercício do recolher, impondo a si um novo tipo de distanciamento com relação à obra. Além disso, o artista do banal, ao decidir deixar de ser aquele que observa para ser

\footnotetext{
${ }^{370}$ BAQUÉ. Photographie plasticienne, l'extrême contemporain, 2004, p. 23.

${ }^{371}$ Ibidem, p. 27.

${ }^{372}$ FRANCBLIN. La passion du réel. In: Art press, Hors Série, nº 13, 1992, pp. 35-43.

${ }^{373}$ [...] dans la Photographie, je ne puis jamais nier que la chose a été là. BARTHES. La chambre claire. In: . Euvres complètes, 2002e, p. 851.
} 
aquele que toma parte na experiência do banal, abre espaço para a presença de um novo elemento: o anonimato - condição do homem na multidão indistinta, explicada assim por Blanchot ${ }^{374}$ :

\footnotetext{
O cotidiano é o movimento pelo qual o homem se mantém como que à revelia no anonimato humano. No cotidiano não temos mais nome, temos pouca realidade pessoal e quase não temos uma figura, assim como não temos determinação social para sustentar-nos ou encerrar-nos [...], o cotidiano dissolve as estruturas e desfaz as formas $[\ldots]$.
}

Isso ocorria em função do poder de despersonalização provocado pela máquina fotográfica, um artefato entre o artista e o mundo que, nas suas versões mais simples, não exige conhecimentos técnicos específicos e está disponível a todos os interessados em reproduzir com alguma qualidade o real. É nesse momento que o artista preocupado com o real deixa de ser o centro da obra: o real agora é a obra. Para que isso acontecesse, a obra deveria apresentar um real imediato, reconhecível, evidente, sem trapaças e truques (a simples dúvida serviria para descartar a experiência como verdadeira), podendo ser, de alguma maneira, apalpado, chegando ao observador nas mesmas dimensões/condições de outras experiências já vivenciadas por ele, sendo então passível de comparação e comprovação. É assim que, por meio da neutralidade da obra, o observador se reconhece como agente que confere significado a ela, do mesmo modo que faria no curso das suas atividades diárias. Para conseguir tudo isso, o artista do real deve aceitar uma condição difícil de assumir, aquela que, inexoravelmente, conduz ao apagamento da autoria já que, segundo Francblin: "a obra a mais real é quase sempre uma obra não assinada". ${ }^{375}$

\footnotetext{
374 BLANCHOT. A fala cotidiana. In: A conversa infinita, 2007, p. 241.

${ }^{375}$ L'euvre la plus réelle est presque toujours une oeuvre non signée. FRANCBLIN. La passion du réel. In: Art press, Hors Série, nº 13, 1992, p.43.
} 


\subsection{1. Édouard Levé e o neutro}

Eu arquivo. ${ }^{376}$

Édouard Levé

Éduard Levé (1965-2007) ingressa no campo literário de maneira singular ao publicar Euvres [Obras] em $20022^{377}$. O conteúdo do livro é revelado no incipit: "[Obra nº 1 . Um livro descreve as obras as quais o autor teve a ideia, mas que não realizou." 378 (E, p. 7). Ao todo, Levé descreve 533 obras de arte através de textos que ora são muito breves - por exemplo, 'Obra $n^{\circ}$ $15^{\prime}$, com uma única linha de texto -, e ora são longos - por exemplo, 'Obra $n^{\circ} 83$ ' com oito páginas de texto. Essas obras abarcam as mais variadas modalidades artísticas: vídeo, literatura, fotografia, grafite, desenho, performance, instalação, música, arquitetura etc. No final do livro - como ocorre com diversos livros de Perec -, o autor incluiu um índice de doze páginas com a indicação do que pode ser encontrado no livro.

203. Un litre d'eau est retenu en l'air, sous forme de sphère, par des souffleries contraires.

204. Deux chênes sont plantés à une distance de trois mètres. Lorsqu'ils en mesurent cinq, leurs cimes sont attachées et greffées. Ils continuent de pousser, en lambda.

205. Dans une bibliothèque, un enfant assis à une table dessine un lion sur une feuille blanche. Il porte une mâchoire de Dracula en plastique. Photographie.

206. Un fromage humain est fabriqué à partir de lait maternel.

207. Une peinture est réalisée en donnant exclusivement des coups de brosse obliques de droite à gauche de la toile.

208. Des têtes en glaise à l'effigie d'écrivains et d'artistes servent, encore fraîches et modelables, de visages témoins lors de la reconstitution de leurs morts violentes. Puis elles sont cuites. Jean Eustache, Roland Barthes, Albert Camus, Nicolas de Staël, Pier Paolo Pasolini, Ana Mendieta, Gilles Deleuze.

87

Figura 19 - Édouard Levé. Cuvres, 2002, p. 87.

\footnotetext{
376 J'archive. LEVÉ. Autoportrait, 2008b, p. 7.

377 Esse autor teve uma carreira curta e publicou apenas quatro livros de textos: CEuvres (2002), Journal [Jornal] (2004), Autoportrait [Autorretrato] (2005) e Suicide [Suicídio] (2008). Paralelamente à sua obra literária, ele também publicou três livros de fotografias: Angoisse, Reconstitutions [Angústia, Reconstituições] (2003), Amérique [América] e Fictions [Ficções] (2006).

${ }^{378}$ 1. Un livre décrit des æuvres dont l'auteur a eu l'idée, mais qu'il n’a pas réalisées.
} 
Isso que Levé propõe em CEuvres de forma exaustiva, diversificada e interdisciplinar no campo das artes, é semelhante pelo desejo de quantidade à ambição revelada por Perec em Notes sur ce que je cherche: percorrer todos os caminhos possíveis para um escritor do seu tempo. Por interesses tão diversificados, a obra de Édouard Levé se apresenta como pura hibridação (à maneira de Joe Brainard) e, mesmo que sua produção se divida entre livros de texto e livros de fotografias, muito da sua literatura trata de questões plásticas, da mesma forma que seus ensaios fotográficos sempre envolvem questões de linguagem, com destaque para a palavra. Euvres é um exemplo do que é inquietante na sua produção e sucita a pergunta: o livro é um catálogo utópico do artista ou é o museu imaginário do escritor? Provavelmente os dois. Levé contou a Jacques Morice que, quando seu editor lhe apresentou o contrato para a publicação de Euvres e Levé precisou escolher o gênero que sua obra seria classificada para entrar no catálogo da editora, Levé não identificou nenhum gênero dizendo que "Euvres não era catalogável já que se trata de um catálogo!" 379 Decidiram então classificá-la como 'poesia', já que "no fundo, poesia, é o gênero que aceita tudo." ${ }^{380}$ Mas a incerteza de CEuvres não se limita unicamente ao seu gênero já que também é difícil entender que trabalhos tão distintos quanto os listados por Levé configurem a proposta de um único artista. Exemplo disso são as obras descritas na página 87 (fig. 19):

[Obra $\mathrm{n}^{\circ}$ ] 203. Um litro de água é mantido no ar, sob a forma de esfera, por meio de jatos contrários de ar.

[Obra $\mathrm{n}^{\circ}$ ] 204. Dois carvalhos são plantados a uma distância de três metros. Assim que eles alcançam a altura de cinco metros, seus topos são amarrados e enxertados. Eles continuam se desenvolvendo, em lambda.

[Obra $\mathrm{n}^{\circ}$ ] 205. Em uma biblioteca, um garoto sentado a uma mesa desenha um leão sobre uma folha branca de papel. Ele usa uma prótese de plástico de Drácula. Fotografia.

[Obra $\left.\mathrm{n}^{\circ}\right]$ 206. Um queijo humano é fabricado a partir de leite maternal.

[Obra $\mathrm{n}^{\circ}$ ] 207. Uma pintura é realizada dando-se exclusivamente golpes de pincel oblíquos da direita para a esquerda da tela.

[Obra $\mathrm{n}^{\circ}$ ] 208. Cabeças em argila retratando escritores e artistas servem, ainda frescas e modeláveis, de rostos testemunhas por ocasião da reconstituição de suas mortes violentas. Em seguida elas são cozidas. Jean Eustache, Roland Barthes,

\footnotetext{
${ }^{379}$ Euvres n'était pas catalogable alors que c'est un catalogue! MORICE. L'écrivain et photographe Édouard Levé est mort. 22 oct. 2007. (Télérama $\mathrm{n}^{\circ} 2888,2005$ ).

${ }^{380}$ Au fond, poésie, c'est le genre qui accepte tout. Ibidem.
} 
Albert Camus, Nicolas de Staël, Pier Paolo Pasolini, Ana Mendieta, Giles Deleuze. (E, p. 87)

A reprodução dessa página (fig. 19) também serve como exemplo de comparação para o que fizeram Perec, em Je me souviens, e Brainard em I remember - dois autores que interessavam a Levé e que também trabalhavam com coleções heteróclitas de fragmentos textuais avulsos. Quanto à linguagem, há um esforço dos três autores - e de maneira enfática por parte de Perec e Levé - em explorar o que Barthes ${ }^{381}$ chamou de 'escrita branca': um tipo de escrita que se restringisse unicamente ao que na linguagem é indicativo e instrumental, sendo então uma escrita sem segredos, transparente e direta. Se com essa estratégia Perec equiparava sua escrita em Je me souviens ao conteúdo impessoal das lembranças coletivas e das coisas comuns, Levé tomou esse recurso para compor uma linguagem de catálogo que apagasse a sua presença e concentrasse os interesses da escrita na formulação das ideias contidas em cada uma das obras. ${ }^{382}$

Ainda contrapondo as obras de Brainard, Perec e Levé, a maior diferença entre elas está no fato de Brainard e Perec se empenharem por resgatar o passado enquanto que Levé constrói um campo de possíveis (ideia que será aprofundada no item seguinte) que limita e concentra o que o autor acredita realizar.

Uma característica importante do trabalho de Levé é o uso de dois tipos de contraintes: a que ele leva para a vida, e é semelhante ao que Perec faz, por exemplo, com Lieux, e a outra é formal e trata das regras determinadas pelo artista para compor a sua obra, como é o caso do lipograma em 'e' de La disparition, também de Perec.

Perguntado por Mathilde Villeneuve se ele havia escrito Euvres para preencher uma falta, Levé respondeu que não, que essa obra não preenchia uma falta, mas que revelava uma falta, ou seja, que Euvres projetava para o futuro o que o artista ainda estava por realizar, e completava:

O livro funcionaria então como um catálogo raisonné ${ }^{383}$ pré-póstumo, um programa de vida por realizar, uma agenda até minha morte cuja totalidade das

${ }^{381}$ BARTHES. L'écriture et le silence. (1953). In: Cuvres Complètes, 2002a, pp. 216-218.

${ }^{382}$ É importante lembrar que, se no exercício da coleção a figura do autor/colecionador é o centro para o qual convergem os objetos colecionados, no exercício do arquivo, como se verá mais adiante, todas as atenções se voltarão para a relação do leitor/observador com o arquivo proposto pelo artista.

${ }^{383}$ CATÁLOGO RAISONNÉ: No campo das artes visuais é o nome dado a uma publicação que contém todo tipo de informação técnica e documental a respeito das obras realizadas por um artista, contendo fotografias, descrições, dimensões, ano, técnica etc. Ele pode ser dividido em vários volumes e organizado de diversas maneiras, como, por exemplo, segundo as técnicas e/ou procedimentos artísticos adotados pelo artista. 
páginas estaria preenchida.

Assim, certas obras são irrealizáveis. Nesse caso, a escrita preenche uma falta: ela realiza as coisas virtualmente, na falta de poder fazê-lo fisicamente. ${ }^{384}$

Levé preferia trabalhar a partir de projetos e contraintes, já que assim ele podia direcionar suas ações e criar uma rotina de trabalho, acompanhando o que o OuLiPo preconizava: pesquisar novas estruturas anti-acaso que permitissem uma independência de qualquer tipo de inspiração.

Uma das obras presentes em CEuvres que Levé põe em prática e que dialoga com o que Perec fazia em Lieux ao se deslocar aos lugares para trabalhar in situ é a seguinte:

[Obra $\mathrm{n}^{\circ}$ ] 20. Nos Estados Unidos, uma viagem é realizada para fotografar as cidades homônimas de cidades de outros países. $\mathrm{O}$ itinerário, que as une ao se passar uma única vez por cada uma delas, faz a volta do país em treze mil quilômetros. O trajeto começa por Nova York, segue a costa na direção sul, se dirige para oeste até a costa do Pacífico, sobe ao norte, beira o Canadá para reencontrar o nordeste antes de voltar ao ponto de partida. O caminho é percorrido de carro. As cidades atravessadas, por ordem alfabética, são:

AMSTERDAM, BAGDAD, BELFAST, BELGRADE, BELLEVILLE, BERLIN, BETHLEHEM, BETHUNE, BRISTOL, CALAIS, CAMBRIDGE, CANTON, CARLSBAD, CARTHAGE, CLERMONT, CUBA, DELHI, DUBLIN, FLORENCE, FRANKFORT, GLASGOW, HEIDELBERG, JERICHO, JOHANNESBURG, LIMA, LIVERPOOL, MACON, MADRAS, MADRID, MANCHESTER, MELBOURNE, MEXICO, MILAN, MILO, MONTEVIDEO, NAPLES, ODESSA, OXFORD, PANAMA, PARIS, PEKIN, POTSDAM, ROME, ROTTERDAM, SAINT-CLOUD, SEVILLE, STOCKHOLM, STUTTGART, SYRACUSE, TORONTO, TOULON, VERSAILLES.

Nessas cidades, são fotografados os lugares comuns, no duplo sentido dos lugares banais e lugares onde a comunidade se encontra. As fotografias são apresentadas acompanhadas de um título: Cuba, a prefeitura; Um bar em Berlin; Supermercado em Roma; Salão de Cabeleireiro em Paris; Uma rua de Versailles. Descritivos enganadores, sem serem falsos. ${ }^{385}$ (E, pp. 12-13)

${ }^{384}$ Le livre fonctionnerait alors comme un catalogue raisonné pré-posthume, un programme de vie à accomplir, un agenda jusqu'à ma mort dont toutes les pages seraient remplies.

Cela dit, certaines auvres sont irréalisables. Dans ce cas, l'écriture comble un manque: elle réalise les choses virtuellement, à défaut de pouvoir le faire physiquement. VILLENEUVE. Interview. In: Paris-Art, 2003.

${ }^{385}$ [Euvre $\mathrm{n}^{\circ}$ ] 20. Aux États-Unis, un voyage est accompli pour photographier des villes homonymes de villes d'autres pays. L'itinéraire, qui les relie en ne passant qu'une fois dans chacune d'elles, fait le tour du pays en treize mille kilomètres. Le trajet commence par New York, longe la côte est vers le Sud, se dirige vers l'Ouest jusqu'à la côte pacifique, remonte au Nord, longe le Canada pour rejoindre le Nord-Est avant de retourner au point de départ. Le chemin est parcouru en voiture. Les villes traversées sont, par ordre alphabétique:

AMSTERDAM, BAGDAD, BELFAST, BELGRADE, BELLEVILLE, BERLIN, BETHLEHEM, BETHUNE, BRISTOL, CALAIS, CAMBRIDGE, CANTON, CARLSBAD, CARTHAGE, CLERMONT, CUBA, DELHI, DUBLIN, FLORENCE, FRANKFORT, GLASGOW, HEIDELBERG, JERICHO, JOHANNESBURG, LIMA, LIVERPOOL, MACON, MADRAS, MADRID, MANCHESTER, MELBOURNE, MEXICO, MILAN, MILO, MONTEVIDEO, NAPLES, ODESSA, OXFORD, 
Como ocorreu com Perec em Lieux, a contrainte em Amérique deixa de coordenar unicamente as forças envolvidas na produção da obra e direciona também os passos do artista na condução de uma ação que decorre no espaço da vida do autor no período de duração do projeto. A viagem durou três meses e o artista percorreu de carro dez mil quilômetros. $\mathrm{O}$ ensaio fotográfico publicado em Amérique não incluiu todas as cinquenta e duas cidades previstas em Euvres, mas quinze delas: Florence, Berlin, Jéricho, Oxford, Stockholm, Rio, Delhi, Amsterdam, Paris, Rome, Mexico, Lima, Versailles, Calcutta e Bagdad. Ao chegar a essas cidades, Levé buscava comprovar seu deslocamento através de fotografias nas quais fosse possível ler o nome da cidade em uma placa de estrada, em um outdoor, em um cartaz, etc.. Na fotografia Entrée de Paris [Entrada de Paris] (fig. 20), por exemplo, é possível ler o nome da cidade numa plaquinha no alto de um poste: Paris. É com essas imagens que ele introduz os 'lugares comuns' - denominação com o mesmo duplo sentido dado por Perec às ‘coisas comuns' e que, na obra de Levé, designa tanto os lugares desinteressantes quanto aqueles que podem ser compartilhados por muita gente.

O livro Amérique apresenta 130 fotografias em formato quadrado, ocupando, cada uma, uma página não numerada. Além das informações bibliográficas padrão, o livro contém apenas uma folha ao final com os nomes das cidades e as legendas das fotografias. Não há qualquer informação complementar sobre o autor, a natureza do trabalho, o ano, ou mesmo a localização exata das cidades visitadas.

Levé explica o uso da contrainte para seus trabalhos fotográficos dizendo não ser da sua natureza fotografar ao acaso e que, por isso, precisa inventar restrições para ter um álibi para enfrentar a realidade (campo por excelência do imprevisível). Para Édouard Levé, as restrições da contrainte também servem como justificativa para ele se aproximar do real e de seus interlocutores sem a necessidade de estabelecer relações pessoais ou qualquer tipo de intimidade. Dessa forma, tudo - sua aproximação, a fotografia, o fotografado - ocorre no campo da neutralidade.

PANAMA, PARIS, PEKIN, POTSDAM, ROME, ROTTERDAM, SAINT-CLOUD, SEVILLE, STOCKHOLM, STUTTGART, SYRACUSE, TORONTO, TOULON, VERSAILLES.

Dans ces villes, sont photographiés des lieux communs, au double sens de lieux banals et de lieux où la communauté se retrouve. Les photographies sont présentées accompagnées d'un titre: Cuba, la mairie; Un bar à Berlin; Supermarché à Rome; Salon de coiffure à Paris; Une rue à Versailles. Descriptifs trompeurs, sans être faux. 


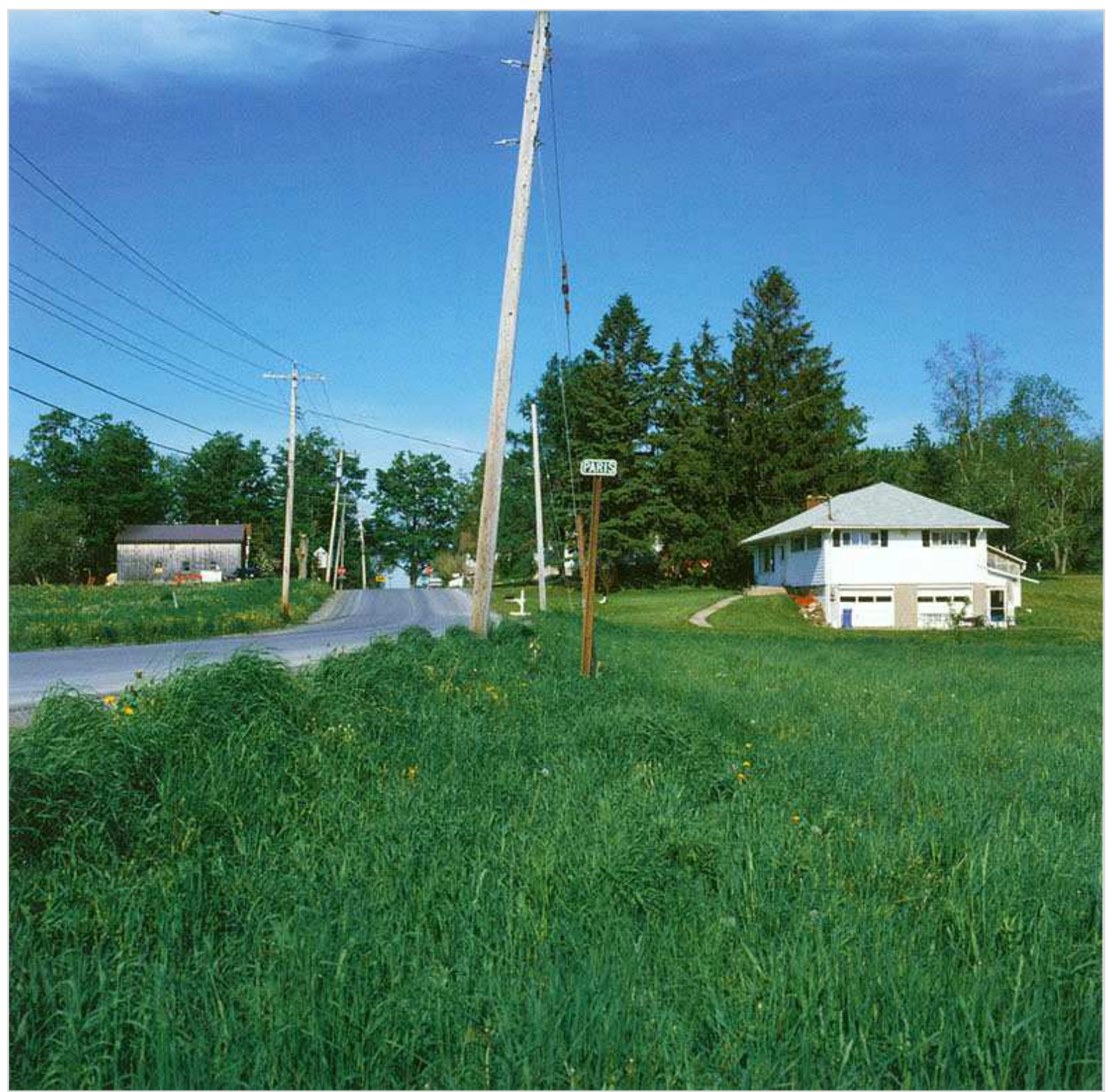

Figura 20 - Édouard Levé. Entrée de Paris [Entrada de Paris], fotografia.

Essa é a maneira desse artista abordar o comum: escolhendo meios e situações em que as marcas de vida são discretas. Na série Amérique, seus personagens são impassíveis e tudo está a serviço da composição de imagens estáticas onde persiste um sentido de repetição. Levé fotografa com tripé, a meia altura do corpo, com uma grande profundidade de campo (tudo ali está focado e nenhum plano é privilegiado); a luz é na maior parte das vezes homogênea e com poucas sombras. A composição das imagens é padronizada por uma austeridade geométrica, centralizada geralmente num único objeto, pessoa ou algum tipo de marco. Esse tipo de composição que se repete ao longo do livro através de fotografias de paisagens, do interior de um supermercado (fig. 21) ou de uma moradora de trailer (fig. 22), caracteriza o 
que Barthes chama de 'fotografia unária':

A Fotografia é unária quando ela transforma enfaticamente a "realidade", sem duplicá-la, sem fazê-la vacilar (a ênfase é uma força de coesão): nenhum duelo, nenhum indireto, nenhum distúrbio. A Fotografia unária tem tudo para ser banal, sendo a "unidade" da composição, a primeira regra da retórica vulgar (e especialmente escolar): "O assunto, diz um conselho aos fotógrafos amadores, deve ser simples, desvencilhado de acessórios inúteis; isso tem um nome: a busca da unidade." 386

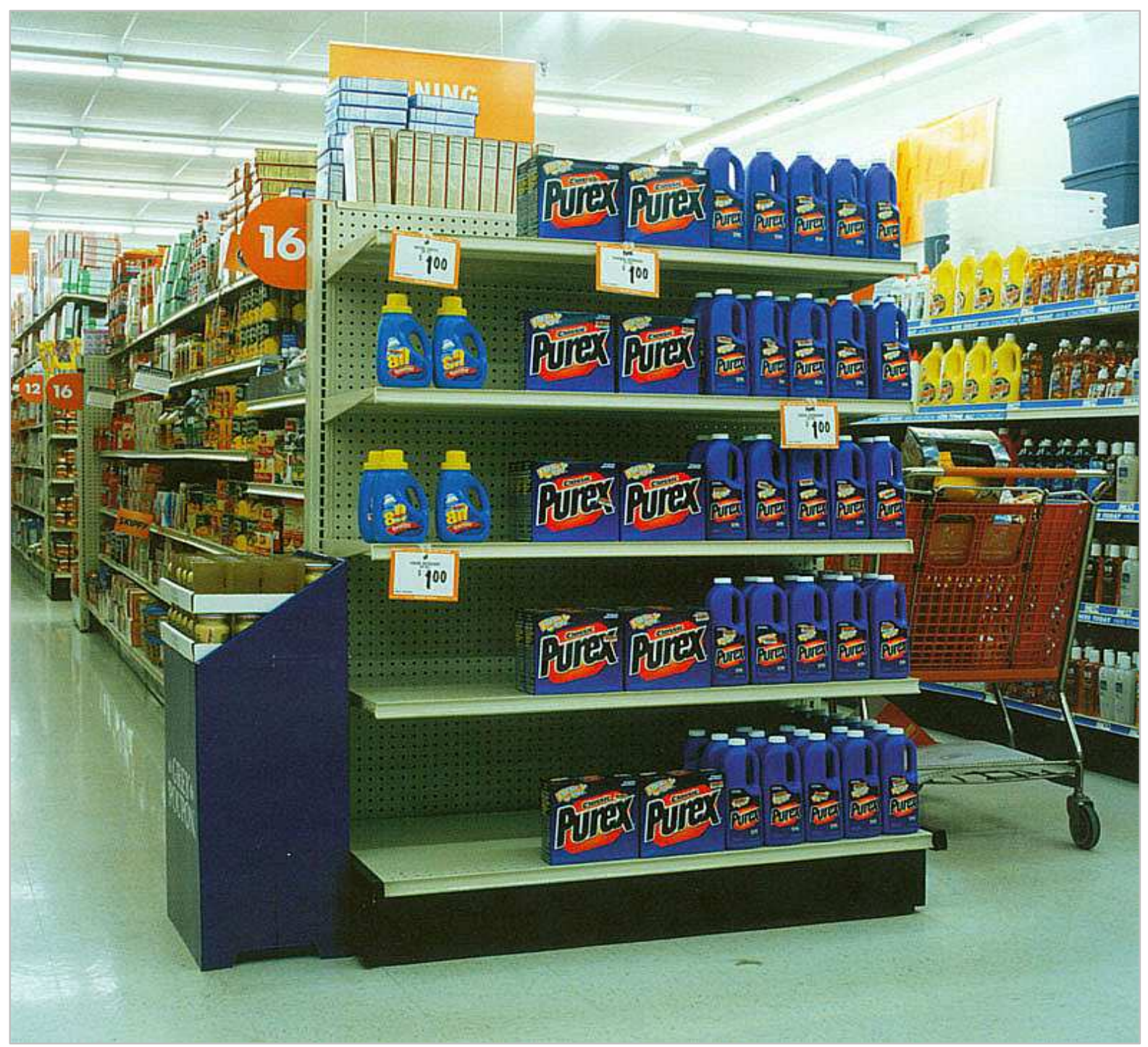

Figura 21 - Édouard Levé. Supermarché de Calcutta [Supermercado de Calcutá], fotografia.

${ }^{386}$ La Photographie est unaire lorsqu'elle transforme emphatiquement la "réalité" sans la dédoubler, la faire vaciller (l'emphase est une force de cohésion): aucun duel, aucun indirect, aucune disturbance. La Photographie unaire a tout pour être banale, l' "unité" de la composition étant la première règle de la rhétorique vulgaire (et notamment scolaire): "Le sujet, dit un conseil aux amateurs photographes, doit être simple, débarrassé d'accessoires inutiles: cela porte un nom: la recherche de l'unité." BARTHES. La chambre claire. In: Euvres complètes, 2002e, p. 821. 
Esse aspecto morno das imagens de Levé é o que enfraquece todo e qualquer gesto e/ou intenção e/ou marca do seu autor, reafirmando o que já citei de Francblin no item anterior: que "a obra a mais real é quase sempre uma obra não assinada". Mas nem essa aproximação do real nem a cotidianidade se apresentam através de imagens isoladas, esses conceitos precisam de várias imagens para se revelar.

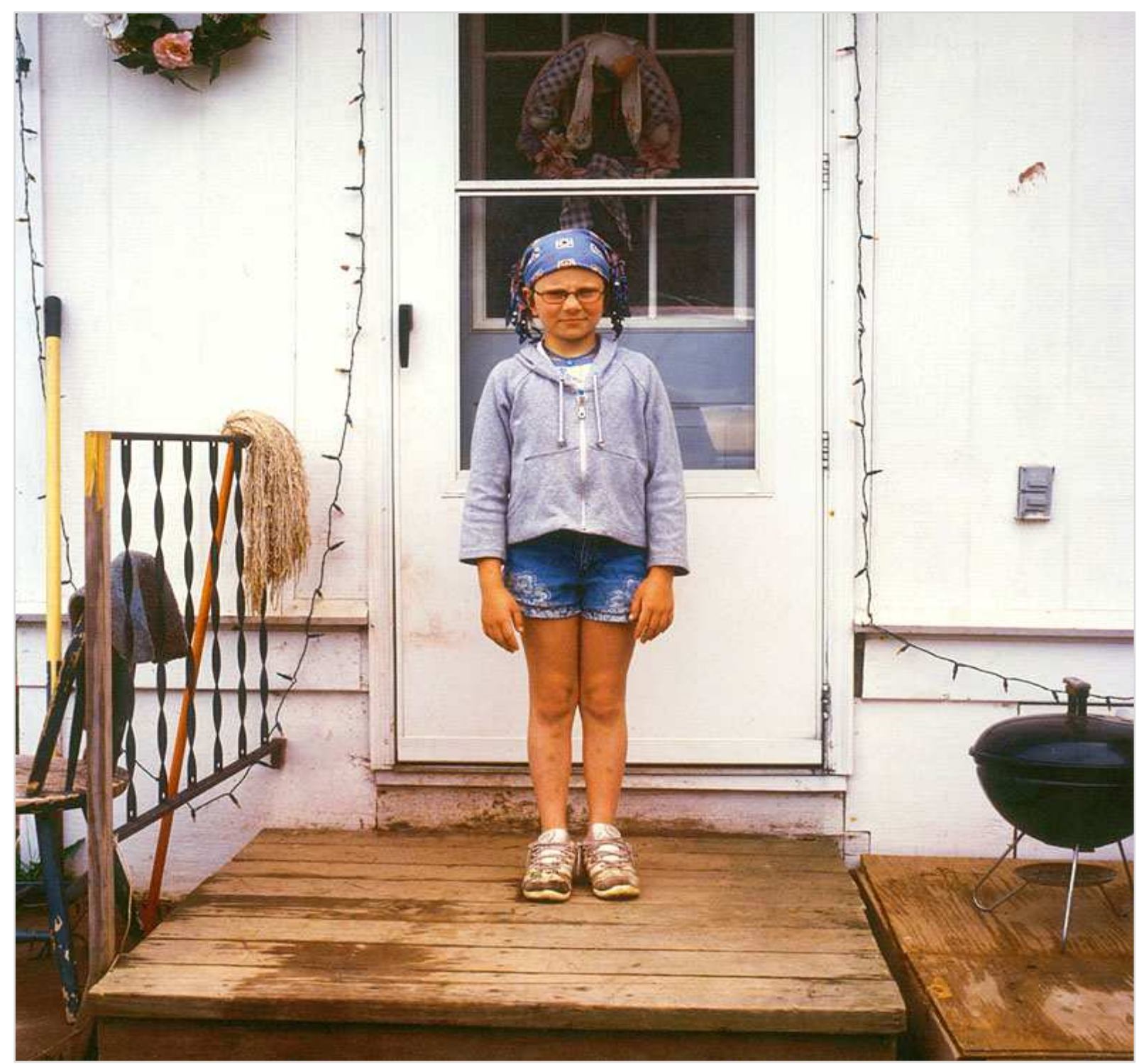

Figura 22 - Édouard Levé. Habitante de mobile home de Delhi. [Moradora de trailer de Delhi], fotografia.

Levé afirmava não produzir sequências, que é quando existe um sentido de passagem e de interdependência entre as várias imagens do grupo, criando assim uma narrativa. $\mathrm{O}$ trabalho de Levé é feito por séries - grupos de imagens autônomas sujeitas a um mesmo tema. $\mathrm{Na}$ abordagem das coisas comuns por Levé, o sentido da série ganha novo significado pelas 
palavras de Blanchot ${ }^{387}$ : “o cotidiano é aquilo que não vemos nunca uma primeira vez, mas que só podemos rever, tendo sempre já o visto por uma ilusão que é precisamente constitutiva do cotidiano." Em Amérique, o observador não se depara com novidades, mas com um estranhamento provocado por três tipos de divergência: o que se vê nas fotografias; o que se lê nas legendas das fotografias; e o que se sabe (ou se lembra) sobre o que cada nome de cidade identifica. São essas divergências que mobilizam o observador a prestar atenção àquilo que, num primeiro momento, parecia não ter nada a mostrar, e que é exatamente o que Perec nos incita a pesquisar (cf. item 2.1.2.1.).

Jean-Max Colard reconhece na obra de Levé uma 'arte do paradoxo' na qual o artista produz uma obra expressiva a partir do inexpressivo e um sentido caloroso a partir da frieza dos procedimentos que emprega, e completa:

A originalidade de sua obra se mantém à distância, já explorado por Georges Perec e outros oulipianos, entre uma série de operações frias, de protocolos estéticos, de neutralização dos afetos de um lado, mas para obter de volta imagens e textos abertos à pluralidade dos sentidos, naturalmente críticos e distantes a respeito dos meios de comunicação, ou ainda banhando em um estranho clima onírico. $^{388}$

Logo após a publicação de Euvres, Levé começou a realizar novos trabalhos que não constavam do livro de estreia. O artista descobria novas possibilidades de tratar o desimportante, desviando a atenção do leitor das obras por fazer para novas ideias de obras. Era como se Levé reordenasse os elementos contidos no índice de Euvres, fazendo surgir novas contraintes, novas relações, novos estranhamentos, novas possibilidades de aproximação do cotidiano banal. Se o exercício que relacionava essas variáveis resultou em poucas obras, ele permaneceu em aberto para que leitores/artistas atentos e interessados continuassem o que ele começou.

\footnotetext{
${ }^{387}$ BLANCHOT. A fala cotidiana. In: A conversa infinita, 2007, p. 237.

${ }^{388}$ L'originalité de son oeuvre tient à ce grand écart, déjà exploré par Georges Perec et autres oulipiens, entre une série d'opérations froides, de protocoles esthétiques, de neutralisation des affects d'un côté, mais pour obtenir en retour des images et des textes ouverts à la pluralité du sens, volontiers critiques et distants à l'égard des médias, ou encore baignant dans un étrange climat onirique. COLARD. "Ma mort ne changera rien.” In: Les Inrockuptibles, $n^{\circ}$ 621, 2007, p. 36.
} 


\subsection{A ideia como máquina de fazer arte}

Eu vou me referir ao tipo de arte com o qual estou envolvido como arte conceitual. $\mathrm{Na}$ arte conceitual a ideia do conceito é o aspecto mais importante do trabalho. Quando um artista usa uma forma conceitual de arte, isso significa que todo o planejamento e decisões são definidos anteriormente e a execução é uma questão mecânica. A ideia se transforma em uma máquina que faz arte. ${ }^{389}$

Sol Lewitt

Nos anos sessenta, enquanto muitos artistas se dedicavam a renovar formas tradicionais da arte e outros ainda se voltavam para o objeto de consumo, havia um grupo de artistas que acreditava ser mais importante questionar a linguagem da arte do que exatamente a sua forma. Desta vez, esse tipo de preocupação não se limitava a um único grupo, morador de uma única região e que agia sob influência de uma única ideologia ou a serviço de um único propósito: em várias partes do mundo, e sob diversas configurações, artistas deslocavam o foco de luz que há décadas iluminava as qualidades materiais, técnicas, formais, de representação e/ou interpretação na composição de uma obra singular para se voltar àquilo que suas ações provocavam enquanto reflexões e questionamentos.

A denominação 'Arte Conceitual' foi empregada pela primeira vez em 1967 pelo artista norte-americano Sol Lewitt no artigo Paragraphs on conceptual art [Parágrafos sobre arte conceitual], publicado na revista Artforum. Eu transcrevo aqui alguns pontos desse artigo que ajudam a esclarecer uma mudança importante que passou a orientar uma parte considerável da produção artística contemporânea. Sol Lewitt escreve:

A aparência da obra de arte não é muito importante. Ela tem que se parecer com algo
se ela tem uma forma física. Não importa que forma ela finalmente tenha, ela precisa
começar com uma ideia. É com o processo de concepção e realização que o artista
está envolvido. [...]
Trabalhar com um plano que é predefinido é uma maneira de evitar a
subjetividade. [...] Isso elimina o arbitrário, o caprichoso, e o subjetivo tanto
quanto possível. Essa é a razão para usar esse método.
[...]
Se o artista leva adiante sua ideia e faz dela uma forma visível, então todos os passos
no processo são importantes. A própria ideia, mesmo que não resulte em algo
visual, é uma obra de arte tanto quanto qualquer produto finalizado. Todos os
passos que intervém - rabiscos, esboços, desenhos, trabalho que não deu certo,

${ }^{389}$ I will refer to the kind of art in which I am involved as conceptual art. In conceptual art the idea of concept is the most important aspect of the work. When an artist uses a conceptual form of art, it means that all of the planning and decisions are made beforehand and the execution is a perfunctory affair. The idea becomes a machine that makes the art. LEWITT. Paragraphs on conceptual art. (1967). In: ALBERRO; STIMSON. Conceptual art: a critical anthology, 2000, p. 12. 
modelos, estudos, pensamento, conversas - são importantes. Aqueles que mostram o processo de raciocínio do artista são às vezes mais interessantes que o produto final. [...] Arte conceitual só é boa quando a ideia é boa. ${ }^{390}$

Como salienta Paul Ardenne ${ }^{391}$, mesmo que os artistas nunca tivessem ignorado o valor da concepção mental na proposição de suas obras, agora, isso tomava uma nova dimensão e o termo 'ideia', ligado à arte, ganhava ênfase ao identificar tanto projeto quanto proposição de sentido. Para que esse tipo de deslocamento fosse possível e a ideia recebesse o destaque devido, alguns artistas conceituais abafavam as duas pontas do processo de criação, ou seja, a presença do artista enquanto criador da obra, e a confecção da própria obra enquanto produto singular, resultado de um processo gerador de sentidos.

No início dos anos setenta, os artistas do grupo Arte \& Linguagem ${ }^{392}$ consideravam mais produtivo tirar a atenção do que preparava a obra, e se voltar para as informações e/ou sistemas que alimentavam os conteúdos que levariam à produção da obra: ao invés de autores de obras, eles preferiam ser agentes envolvidos numa prática que produzia transformações e conhecimento - o que poderia, ou não, ser chamado de 'obra'.

Aqui é importante lembrar Roland Barthes que, nessa mesma época, tratava em seus textos de questionamentos muito semelhantes àqueles dos artistas conceituais, já que não se limitavam ao campo literário e se expandiam para a linguagem. Em La mort de l'auteur [A morte do autor ${ }^{393}$, Barthes proclamava que no texto literário moderno não era o autor que falava, mas a linguagem. Ele também afirmava que o autor era apenas aquele que estava na origem do texto e que, no momento da leitura, surgia uma nova figura: a do scriptor, aquele que nascia a cada leitura junto com o texto que escrevia. A consequência disso é que o sentido de um texto não poderia ser descoberto pelo relacionamento de parentesco que unia um texto

${ }^{390}$ What the work of art looks like isn't too important. It has to look like something if it has physical form. No matter what form it may finally have it must begin with an idea. It is the process of conception and realization with which the artist is concerned. [...] / To work with a plan that is pre-set is one way of avoiding subjectivity. [...] This eliminates the arbitrary, the capricious, and the subjective as much as possible. That is the reason for using this method. / [...] / If the artist carries through his idea and makes it into visible form, then all the steps in the process are of importance. The idea itself, even if not made visual, is as much a work of art as any finished product. All intervening steps - scribbles, sketches, drawings, failed work, models, studies, thought, conversations - are of interest. Those that show the thought process of the artist are sometimes more interesting than the final product. / [...] Conceptual art is only good when the idea is good. LEWITT. Paragraphs on conceptual art. (1967). In: ALBERRO; STIMSON. Conceptual art: a critical anthology, 2000, pp. 13-16.

391 ARDENNE. Conceptualisme et Déconstruction. In: Art. L'Âge Contemporain, 2003, p. 103.

392 O Grupo Arte \& Linguagem surgiu na Inglaterra em 1968, sendo formado inicialmente por Terry Atkinson, Michael Baldwin, Harold Hurrell e David Bainbridge, todos eles professores de teoria da arte em Coventry. No início dos anos setenta o grupo também contaria com artistas de outros países.

${ }^{393}$ BARTHES. La mort de l'auteur. (1968). In: Euvres complètes, 2002c, pp. 40-45. 
a seu autor, mas na relação de proximidade que se estabeleceria a cada leitura, entre o texto e o leitor. Barthes explica:

Um texto é feito de múltiplas escritas, saídas de várias culturas e que entram umas com as outras em diálogo, em paródia, em contestação; mas há um lugar onde essa multiplicidade se ajunta, [...] é o leitor: o leitor é o próprio espaço onde se inscrevem, sem que nada se perca, todas as citações das quais é feita uma escrita; a unidade de um texto não está na sua origem, mas no seu destino [...]. ${ }^{394}$

Ao excluir a possibilidade de encontrar na origem do texto - o autor - seu sentido da leitura, Barthes abria um espaço de liberdade a todo leitor que se dispusesse a percorrer os caminhos incertos da literatura do seu tempo e apreender dali os sentidos possíveis. Barthes torna ainda mais complexa essa tarefa em De l'oeuvre au texte [Da obra ao texto] ${ }^{395}$, quando reconhece que os avanços da interdisciplinaridade já há algum tempo propunham mudanças que não se deixavam apreender pelos campos estabelecidos da ciência: não se tratava aqui de novos objetos e linguagens, mas do que Barthes chamava de glissements [deslocamentos]. É para nomear o novo objeto que surge em face da obra proposta pelos novos autores, que Barthes recorre a um termo que ele utilizava à exaustão, mas que no embate com a obra ganha novos sentidos: o Texto.

Segundo Barthes, enquanto a obra - noção tradicional que eu entendo como uma 'coisa enformada' - seria uma unidade, propriedade do seu autor, o Texto não teria materialidade, autoria, biografia ou psicologia, e seria pura pluralidade e intermediação entre vários textos se realizando sempre no sentido plural. Barthes explica:

a obra é um fragmento de substância, ela ocupa uma parte do espaço dos livros (por exemplo em uma biblioteca). O Texto é um campo metodológico. A oposição poderia lembrar (mas não reproduzir termo a termo) a distinção proposta por Lacan: a "realidade" se mostra, o "real" se demonstra; também, a obra se vê (nas livrarias, nos arquivos, nos programas de exames), o texto se demonstra, se fala segundo certas regras (ou contra certas regras); a obra tem lugar na mão, o texto tem lugar na linguagem: ele só existe no discurso [...]. ${ }^{396}$

${ }^{394}$ Un texte est fait d'écritures multiples, issues de plusieurs cultures et qui entrent les unes avec les autres en dialogue, en parodie, en contestation; mais il y a un lieu où cette multiplicité se rassemble, [...] c'est le lecteur: le lecteur est l'espace même où s'inscrivent, sans qu'aucune ne se perde, toutes les citations dont est faite une écriture; l'unité d'un texte n'est pas dans son origine, mais dans sa destinations [...]. BARTHES. La mort de l'auteur. (1968). In: Euvres complètes, 2002c, p. 45.

${ }^{395}$ BARTHES. De l'ouvre au texte. (1971). In: Euvres complètes, 2002c, pp. 908-916.

${ }^{396}$ L'auvre est un fragment de substance, elle occupe une portion de l'espace des livres (par exemple dans une bibliothèque). Le Texte, lui, est un champ méthodologique. L'opposition pourrait rappeler (mais nullement reproduire terme à terme) la distinction proposée par Lacan: la "réalité" se montre, le "réel" se démontre; de même, l'œuvre se voit (chez les libraires, dans les fichiers, dans les programmes d'examen), le texte se démontre, se parle selon certaines règles (ou contre certaines règles); l'œuvre se tient dans la main, le texte 
Acompanhando ainda as ideias de Barthes ${ }^{397}$, enquanto a obra se apresenta sob os limites do significante e tem um 'pai' - o autor -, o Texto é da ordem do simbólico e não tem 'filiação' - as suas relações se efetivam com outros textos, na horizontalidade. Usando uma metáfora, Barthes reconhece na obra um organismo e no Texto uma rede de possibilidades na qual os movimentos se efetivam por meio de desligamentos, sobreposições e variações. Surge então o maior esclarecimento de Barthes a respeito do que os autores (escritores e artistas) se empenhariam a partir dos anos sessenta e que tem na noção de 'arquivo' uma das suas consequências: enquanto a obra é convertida em objeto de consumo (e Barthes reconhece que naquele momento essa era uma qualidade da obra), o Texto se converte em condição essencial da prática artística, descrita assim por Barthes:

O Texto [...] decanta a obra (se ela o permite) do seu consumo e a recolhe como
jogo, trabalho produção, prática. Isso quer dizer que o Texto requisita que se tente
eliminar (ou pelo menos diminuir) a distância entre a escrita e a leitura, de maneira
alguma intensificando a projeção do leitor na obra, mas ligando esses dois numa
mesma prática significativa. 398

Com a amplificação do exercício interdisciplinar da arte contemporânea - em especial pela Arte Conceitual, que se aproxima de diferentes campos do conhecimento (filosofia, psicologia, antropologia, matemática etc.) -, a materialidade da obra perde relevância enquanto o Texto - tal como Barthes o define - ganha espaço. O que é escrito pelo artista é então pura indicação de um procedimento, pura marcação (traço): o trabalho de escrita do Texto (aquele que é feito pelo scriptor, para usar um termo barthesiano) caberá agora ao receptor. Como exemplos desse novo tipo de procedimento artístico e para indicar a maneira como esses artistas-escreventes (diferentes do que seriam artistas-escritores) fazem uso da palavra em suas obras, cito dois trabalhos bem distintos: I will not make any more boring art [Eu não farei mais arte chata] (1971), de John Baldessari (fig. 23), e Step piece [A peça do degrau] (1970) (figs. 24 e 25), de Vito Acconci.

se tient dans le langage: in n'existe que pris dans un discours [...]. BARTHES. De l'œuvre au texte. (1971). In: Euvres complètes, 2002c, p. 909.

${ }^{397}$ Ibidem, p. 913.

${ }^{398}$ Le texte [...] décante l'œuvre (si elle le permet) de sa consommation et la recueille comme jeu, travail, production, pratique. Cela veut dire que le Texte demande qu'on essaie d'abolir (ou tout au moins de diminuer) la distance entre l'écriture et la lecture, non point en intensifiant la projection du lecteur dans l'œuvre, mais en les liant tous deux dans une même pratique signifiante. Ibidem, p. 914. 
Em 1971, John Baldessari (1931) foi convidado a expor na Nova Scotia College of Art and Design, mas os organizadores não conseguiram levantar o dinheiro suficiente para pagar a viagem do artista. Não podendo estar presente, o artista propõe aos alunos da instituição que escrevessem nas paredes da galeria: "I will not make any more boring art”. Os alunos aceitaram a tarefa, mas ao invés de escreverem uma única vez a frase indicada por Baldessari, eles a escreveram dezenas de vezes

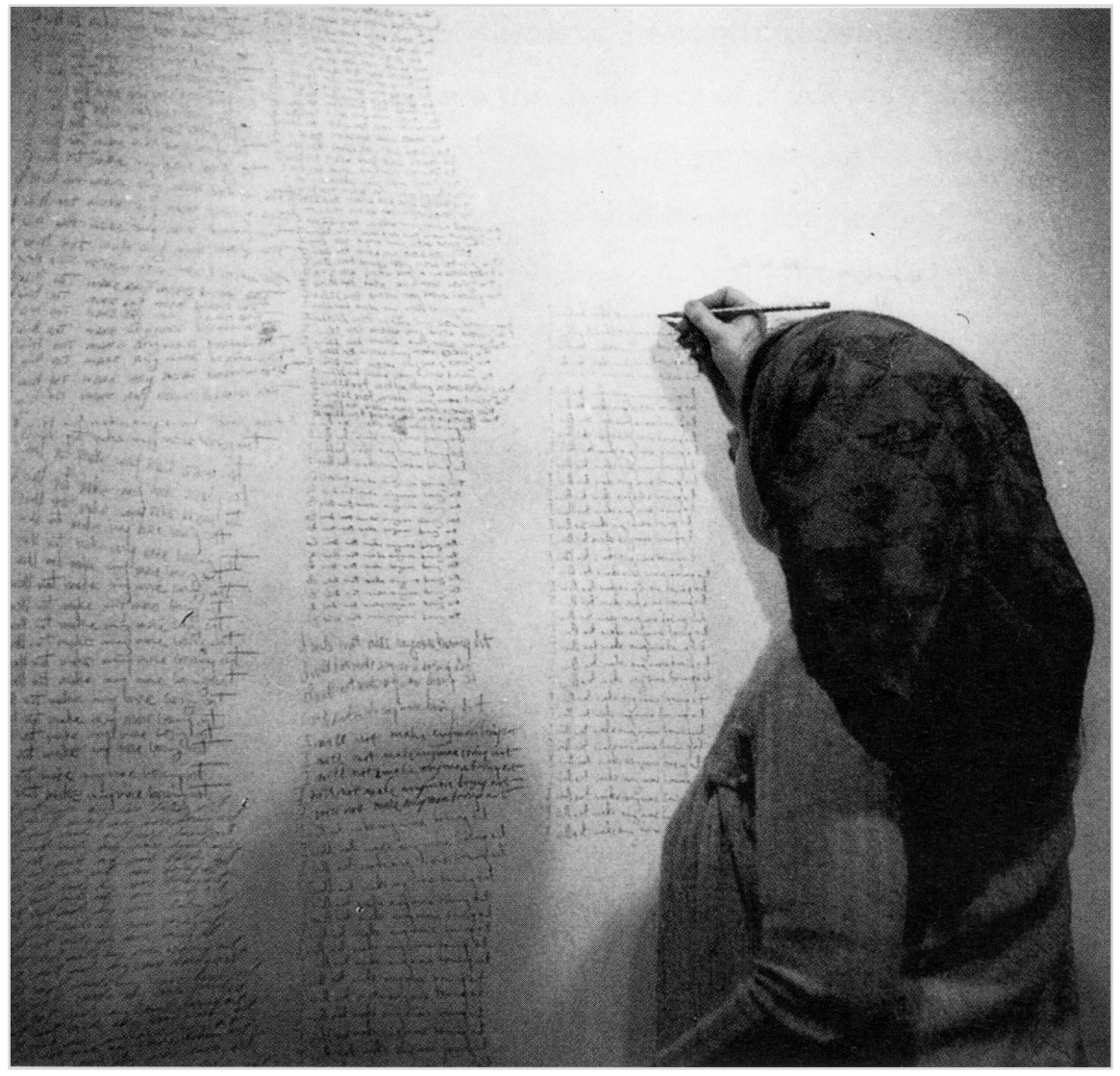

Figura 23 - Alunos de John Baldessari. I will not make any more boring art [Eu não farei mais arte chata] (1971).

até preencherem as

paredes da galeria. A mensagem apresentada pelo artista foi a indicação de uma ação e a resposta dos alunos é que deu significado a ela, primeiro por terem aceito a provocação e, segundo, pela maneira como a executaram: escrevendo a mesma frase inúmeras vezes na parede como se estivessem cumprindo um castigo em sala de aula. O resultado dessa ação também ganhava ares de protesto, visto que ela ocorria no interior de uma instituição de ensino de artes.

Já, o trabalho de Vito Acconci (1940) é de outra ordem, e trata de um ritual: o artista se propunha a subir e descer de um banquinho e a registrar o quanto ele conseguia progredir nessa ação ao longo de um período de tempo. Ele convidava as pessoas a irem até seu apartamento para vê-lo no seu exercício diário e se comprometia a enviar aos visitantes, ao final de cada mês, um relatório dos progressos alcançados. A escrita do artista aqui é uma 
carta de intenções e as fotografias, os relatórios, os convites e as cartas enviadas ao público são documentos que registram e comprovam a intenção inicial.

Tradução: A Peça do Degrau, de Vito Acconci. 399

\author{
(Cf. fig. 24)
}

Vito Acconci
Peça do Degrau

Atividade

102 Christopher Street (minha casa); quatro meses (fevereiro - abril - julho novembro), 1970; 8hs da manhã a cada dia

Um banquinho de quarenta e cinco centímetros é instalado em meu apartamento; a cada manhã ele é usado como uma ferramenta de exercício. A cada manhã, durante os meses predefinidos, eu subo e desço do banquinho à razão de trinta passos por minuto; a cada manhã, eu continuo a atividade contanto que eu o faça sem interrupções.

O treino diário traz aperfeiçoamento diário; a cada dia eu amplio o exercício. O treinamento se torna parte da vida diária. Após as folgas de um mês e de dois meses, os efeitos do treinamento persistem: o aperfeiçoamento é mais rápido do que era durante o primeiro mês de atividade. Assim, após uma folga de três meses, o treinamento começa a se desgastar: volto onde iniciei, eu preciso me preparar novamente.

(A atividade é deixada em aberto; é, em princípio, uma performance pública: anúncios são enviados ao público, que pode vir ver a atividade ser executada no meu apartamento a qualquer hora durante os meses predeterminados. Ao fim de cada mês um relatório de progressos é enviado ao público.)

${ }^{399}$ ACCONCI. Steps into Performance (And Out) (1979). In: STILES; SELZ. Theories and documents of contemporary art 1996, pp. 760-761. 
(Cf. fig. 25)

Vito Acconci

DEGRAUS (MEDIÇÃO DOS DEGRAUS)

Apartamento 6B, 102 Christopher Street, Nova York

8hs da manhã de cada dia; programação revisada: 1970: Fevereiro, Abril, Julho, Novembro...

Projeto: um banquinho de $45 \mathrm{~cm}$ é instalado no meu apartamento e usado como um degrau. A cada manhã, durante os meses predefinidos, eu subo e desço do banquinho à razão de 30 degraus por minuto; a cada manhã, a atividade dura até que eu a desempenhe sem interrupções.

Relatório de Progresso: registro diário do tempo de desempenho:

Segundo mês (abril 1970):

$\begin{array}{lll}\text { Data } & & \text { Duração } \\ \text { Abril } 1 & 7 \mathrm{~min} .30 \mathrm{seg} . \\ 2 & 6 \mathrm{~min} .4 \mathrm{seg} . \\ 3 & 9 \mathrm{~min} .40 \mathrm{seg} . \\ 4 & 8 \mathrm{~min} .35 \mathrm{seg} . \\ 5 & 8 \mathrm{~min} .52 \mathrm{seg} . \\ 6 & 9 \mathrm{~min} .24 \mathrm{seg} . \\ 7 & 10 \mathrm{~min} .8 \mathrm{seg} . \\ 8 & 11 \mathrm{~min} .46 \mathrm{seg} . \\ 9 & 13 \mathrm{~min} .10 \mathrm{seg} . \\ 10 & 14 \mathrm{~min} .22 \mathrm{seg} . \\ 11 & 15 \mathrm{~min} .54 \mathrm{seg} . \\ 12 & 16 \mathrm{~min} .30 \mathrm{seg} . \\ 13 & 17 \mathrm{~min} .28 \mathrm{seg} . \\ 14 & 18 \mathrm{~min} .10 \mathrm{seg} . \\ 15 & 18 \mathrm{~min} .42 \mathrm{seg} . \\ 16 & 19 \mathrm{~min} .20 \mathrm{seg} . \\ 17 & 20 \mathrm{~min} .6 \mathrm{seg} . \\ 18 & 21 \mathrm{~min} .40 \mathrm{seg} . \\ 19 & 22 \mathrm{~min} .52 \mathrm{seg} . \\ 20 & 23 \mathrm{~min} .18 \mathrm{seg} . \\ 21 & 24 \mathrm{~min} .0 \mathrm{seg} . \\ 22 & 24 \mathrm{~min} .34 \mathrm{seg} . \\ 23 & 25 \mathrm{~min} .20 \mathrm{seg} . \\ 24 & 26 \mathrm{~min} .54 \mathrm{seg} . \\ 25 & 28 \mathrm{~min} .0 \mathrm{seg} . \\ 26 & 24 \mathrm{~min} .16 \mathrm{seg} . \\ 27 & 25 \mathrm{~min} .0 \mathrm{seg} . \\ 28 & 27 \mathrm{~min} .50 \mathrm{seg} . \\ 30 & 26 \mathrm{~min} .14 \mathrm{seg} . \\ & 26 \mathrm{~min} .10 \mathrm{seg} . \\ & \\ & & \\ 29 & \end{array}$

Terceira série de performances: julho 1970; 8 hs da manhã de cada dia.

O público pode ver a atividade executada, no meu apartamento em qualquer manhã durante o mês da performance; sempre que eu não estiver em casa, eu executarei a atividade onde eu estiver. 
Através desses dois trabalhos, os artistas ainda efetivavam uma determinada ação no campo do real, mas para outros artistas isso não era uma condição necessária para a manifestação da arte. Sobre isso, Ardenne escreve: “a arte, na ótica conceitual, acabará eventualmente abdicando da realização, resultando apenas o projeto da obra designada a ser realizada ou, de maneira mais frequente, seu programa." ${ }^{400}$ Além disso, há ainda outro aspecto relevante apontado pelo mesmo Ardenne ${ }^{401}$ que fica implícito nesse novo tipo de proposição: a obra de arte, enquanto projeto, toma a forma de um 'contrato' que o artista subscreve e se compromete a realizar, ainda que em condições como estas descritas em Statement, 1969 [Declaração, 1969] de Lawrence Weiner:

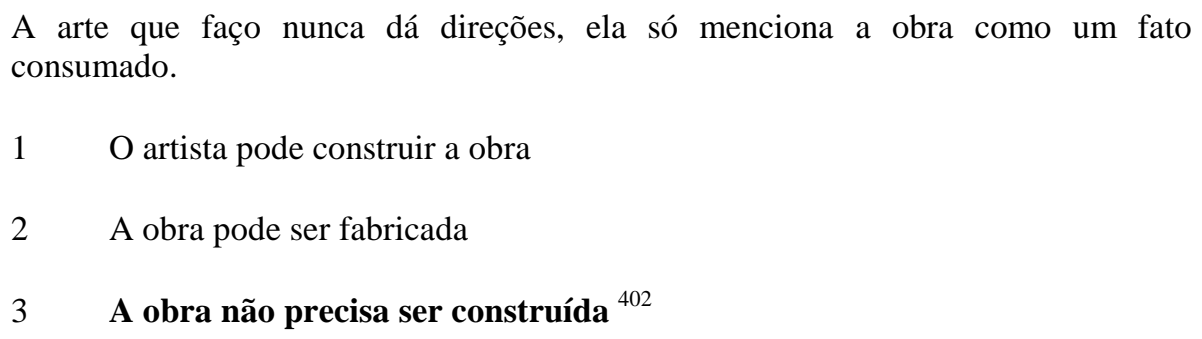

Sem a necessidade de produzir efetivamente a obra, o artista assumia o compromisso de pensar a obra e passar ao público a tarefa de compor um sentido para o que ele colocava a sua disposição. Para que ambos limitassem seus esforços ao campo das ideias, um grupo inglês decide compor um 'arquivo de pensamentos' e sugerir ao público algumas conexões. A obra só se realizaria com o aceite e a mobilização de quem, efetivamente, lesse os textos e buscasse estabelecer as relações propostas.

\footnotetext{
${ }^{400}$ L'art, dans l'optique conceptuelle, en viendra le cas échéant à se passer de la réalisation, seul restant le projet de l'œuvre appelée à être réalisée ou, de manière plus fréquente, son programme. ARDENNE. Conceptualisme et Déconstruction. In: . Art. L'Âge Contemporain, 2003, p. 103.

${ }^{401}$ Ibidem, p. 104.

${ }^{402}$ My own art never gives directions, only states the work as an accomplished fact. / 1 The artist may construct the work / 2 The work may be fabricated / 3 The work need not to be built. WEINER. Statements. (1972). In: HARRISON; WOOD. Art in theory. 1900 - 2000, 2009, p. 893.
} 

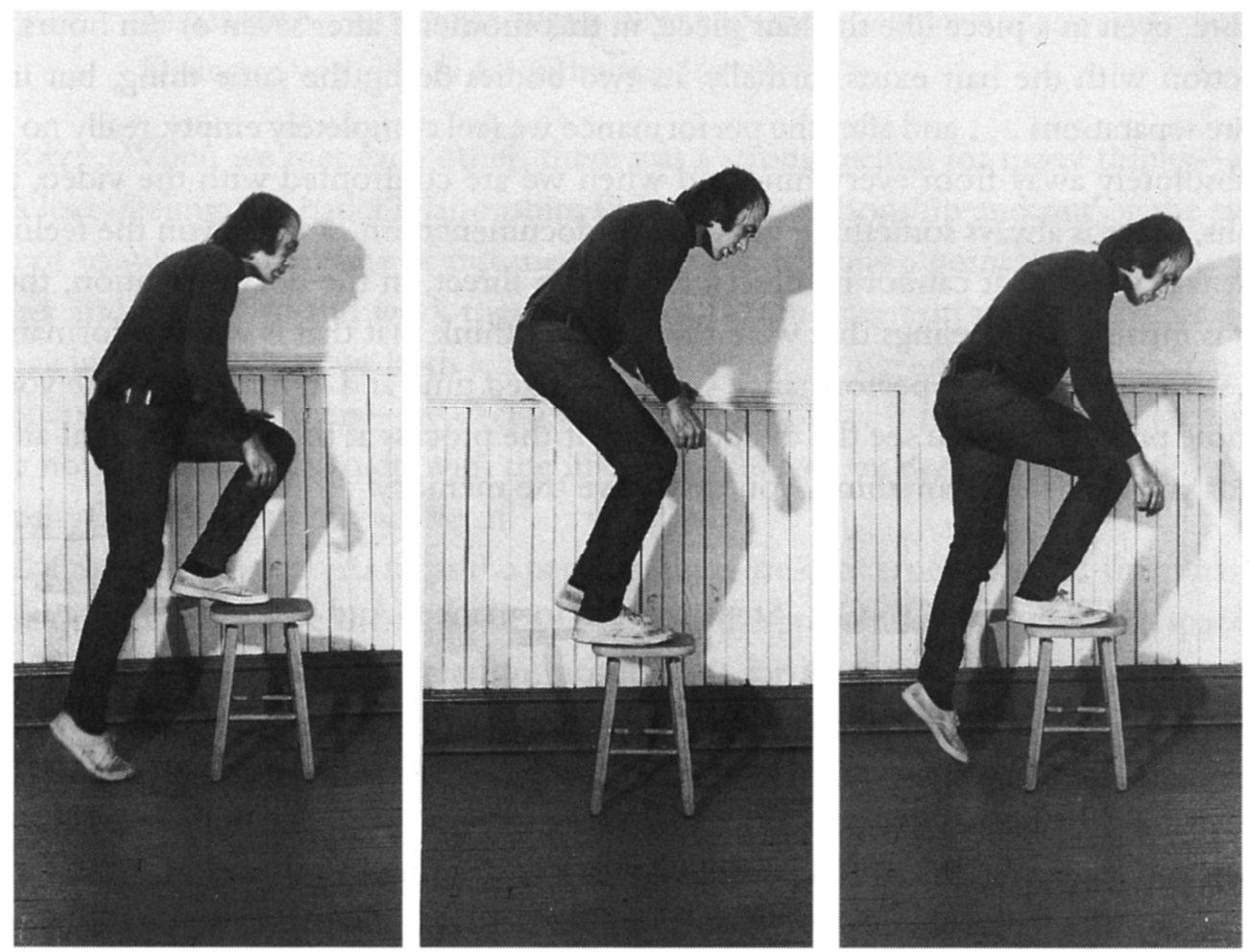

Vito Acconci, Step Piece, 1970.

Vito Acconci

STEP PIECE

Activity

102 Christopher Street (my home); four months (February-AprilJuly-November), 1970; 8AM each day

An eighteen-inch stool is set up in my apartment; each morning it is used as an excercise-tool. Each morning, during the designated months, I step up and down the stool at the rate of thirty steps a minute; each morning, I continue the activity as long as I can do it without stopping.

Daily training makes for daily improvement; each day I can do the exercise longer. The training becomes part of daily life. After the one-month and two-month lay-offs, the effects of the training persist: improvement is more rapid than it was during the first month's activity. Then, after a three-month lay-off, the training begins to wear off: I'm back where I started, I have to work myself up to it again.

(The activity is left open; it is, in principle, a public performance: announcements are sent out to the public, who can come to see the activity carried out, in my apartment, any time during the designated months. At the end of each month a progress-report is sent out to the public.)

Figura 24 - Vito Acconci. Step piece [Peça do degrau], (1970). 
Vito Acconci

STEPS (STEPPING OFF PLACE)

Apartment 6B, 102 Christopher Street, New York City.

8AM each day; revised schedule: 1970: February, April, July, November...

Project: An 18-inch stool is set up in my apartment and used as a step. Each morning, during the designated months, I step up and down the stool at the rate of 30 steps a minute; each morning, the activity lasts as long as I can perform it without stopping.

Progress Report: daily record of performance time: Second month (April 1970):

$\begin{array}{cl}\text { Date } & \\ \text { April } & 1 \\ & 2 \\ & 3 \\ & 4 \\ 5 \\ 6 \\ 7 \\ 8 \\ 9 \\ 10 \\ 11 \\ 12 \\ 13 \\ 14 \\ 15 \\ 16 \\ 17 \\ 18 \\ 19 \\ 20 \\ 21 \\ 22 \\ 23 \\ 24 \\ 25 \\ 26 \\ 27 \\ 28 \\ 29 \\ 30 \\ \end{array}$

\section{Duration}

7 min. $30 \mathrm{sec}$.

6 min. 4 sec.

9 min. $40 \mathrm{sec}$.

$8 \mathrm{~min} .35 \mathrm{sec}$.

8 min. $52 \mathrm{sec}$.

9 min. 24 sec.

$10 \mathrm{~min} .8 \mathrm{sec}$.

11 min. $46 \mathrm{sec}$.

$13 \mathrm{~min} .10 \mathrm{sec}$.

$14 \mathrm{~min} .22 \mathrm{sec}$.

15 min. $54 \mathrm{sec}$.

16 min. $30 \mathrm{sec}$.

17 min. $28 \mathrm{sec}$.

$18 \mathrm{~min} .10 \mathrm{sec}$.

$18 \mathrm{~min} .42 \mathrm{sec}$.

$19 \mathrm{~min} .20 \mathrm{sec}$.

20 min. 6 sec.

21 min. $40 \mathrm{sec}$.

22 min. 52 sec.

$23 \mathrm{~min} .18 \mathrm{sec}$.

24 min. 0 sec.

24 min. 34 sec.

$25 \mathrm{~min} .20 \mathrm{sec}$.

$26 \mathrm{~min} .54 \mathrm{sec}$.

28 min. 0 sec.

$24 \mathrm{~min} .16 \mathrm{sec}$.

25 min. 0 sec.

27 min. 50 sec.

$26 \mathrm{~min} .14 \mathrm{sec}$.

$26 \mathrm{~min} .10 \mathrm{sec}$.

Third series of performances: July 1970; 8AM each day.

The public can see the activity performed, in my apartment any morning during the performance-month; whenever I cannot be home, I will perform the activity wherever I happen to be.

Figura 25 - Vito Acconci. Step piece [Peça do degrau], (1970). 


\title{
3.3.1. O arquivo como promessa
}

Ao trabalhar a obra autobiográfica de Georges Perec, Philippe Lejeune destaca como um dos pontos relevantes da sua produção o que ele chama de 'opérabilité' [operabilidade] e que indica a necessidade de um trabalho a ser feito para que o texto adquira algum sentido:

\begin{abstract}
Esses textos [Lejeune certamente se refere aqui a Lieux e outros textos derivados desse projeto], no fundo, não representam a vida de maneira realista, não dão uma informação, não propõem um sentido, não constroem um 'eu' [...]. Eles mostram alguma coisa em vias de se fazer, que o leitor não pode agarrar a não ser que ele aceite se associar ao movimento. Não são objetos para contemplar, mas instrumentos para fazer funcionar. Eu falei de exercício espiritual. A leitura deve ser a participação a esse exercício: senão, o que sobra no papel não passa de acumulações estranhas ou cansativas, resultados que desafiam o bom senso, listas, banalidades. [...] Hipnose, feitiço, poesia. Dirão que é um trabalho "meia-boca". Não, foi feito para 'estar por fazer'. ${ }^{403}$
\end{abstract}

Lieux é um projeto inacabado e imprevisível desde o momento em que foi proposto, como atesta a carta de Perec a Nadeau ${ }^{404}$. Essa dúvida sobre o destino do trabalho também aparece em algumas das primeiras 'lembranças' escritas por Perec e pesquisadas por Lejeune como, por exemplo, no texto referente à lembrança de Gaité (28/06/1969):

Já poderíamos nos perguntar se a acumulação de textos vai produzir um texto diferente. Qual será exatamente meu trabalho no $1^{\circ}$ de janeiro de 1981 ? Reler e publicar? Estabelecer um índice? (sem dúvida). Reescrever tudo, e só usando esses textos como anotações? ${ }^{405}$

Quanto ao que poderia ter resultado de Lieux, Lejeune, depois de ler todo o material deixado pelo escritor, tem duas certezas: a primeira é que Perec não tinha a menor ideia de como seria a estrutura final do livro, de como os textos estariam organizados, suas divisões, sequências, etc., já que Perec não deixou qualquer indicação sobre isso; já, a outra certeza, diz respeito à obsessão reiterada por Perec sobre a necessidade de compor um índice para Lieux, e

${ }^{403}$ Ces textes, au fond, ne représentent pas la vie de manière réaliste, ne donnent pas une information, ne proposent pas un sens, ne construisent pas un moi [...]. Ils montrent quelque chose en train de se faire, que le lecteur ne peut saisir que s'il accepte de s'associer au mouvement. Ce ne sont pas des objets à contempler, mais des instruments à faire fonctionner. J'ai parlé d'exercice spirituel. La lecture doit être participation à cet exercice: sinon, il ne reste sur le papier que des accumulations étranges ou lassantes, des performances qui défient le bon sens, des listes, des platitudes. [...] Hypnose, envoûtement, poésie. Dira-ton que c'est “ni fait ni à faire”. Non, c'est fait pour être à faire. LEJEUNE. La mémoire et l'oblique, 1991, p. 42.

${ }^{404}$ Cf. itens 2.1.1. e 3.1.1.

${ }^{405}$ On pourrait déjà se demander si l'accumulation des textes va produire un texte différent. Quel sera exactement mon travail au ler janvier 1981? Relire et publier? Établir un index? (sans doute). Tout réécrire, en ne me servant de ces textes que comme de notes ? LEJEUNE. Op. cit., pp. 200-201. 
que Lejeune entende assim: “Os índices (pelos quais Perec tem uma predileção ${ }^{406}$ ) permitem uma circulação infinita nos textos, relativizando a estrutura aparente deles, deixando-a completamente intacta, se um dia se for editar Lieux, será necessário seguir essa indicação."407

A seguir, antes de tratar de parâmetros que fundamentam a constituição do arquivo, fui buscar no campo da Arte Conceitual, um exemplo de trabalho que também constituiu um corpus e propõe um índice para orientar um trabalho que ainda estaria por ser feito. O trabalho é Índice 011972 (figs. 26 e 27) - apresentado pelo grupo Arte \& Linguagem na Documenta $\mathrm{n}^{\circ} 5$ de Kassel, em 1972. Os artistas desse grupo, ao invés de se preocuparem em nomear um determinado objeto e/ou ação, configuraram um tipo de produção artística que Paul Wood ${ }^{408}$ chama de 'uma espécie de obra genérica'.

A instalação consistia em: oito fichários com 87 textos dos participantes do grupo e de outros autores; um índice colocado nas paredes; e um manual de instruções ${ }^{409}$. Paul Wood ${ }^{410}$ explica que através do manual de instruções o espectador/leitor tomava conhecimento de que era possível fazer três tipos de relações entre os textos: compatível (+), incompatível (-) e transformação (T) (textos não comparáveis). Esse último tipo de relação era o mais complexo e significava: "impossível comparar sem que se efetue alguma transformação nos fundamentos da comparação". A partir disso, Wood reconhece que "o critério que se utiliza para classificar o mundo teria um efeito determinante sobre o tipo de mundo que se é capaz de classificar", ou seja, por princípio, não existiria o que designaria determinada coisa como arte, por exemplo, e que só por meio da linguagem e das estruturas conceituais empregadas é que seria possível formular uma reflexão/definição sobre o assunto. Com Índice 01 1972, o espectador/leitor era incitado a se informar sobre o jogo proposto, selecionar um corpus, fazer relações e compará-las com as classificações feitas anteriormente e refletir sobre os

\footnotetext{
${ }^{406}$ Os livros de Perec que contêm índices são: Quel petit vélo à guidon chromé au fond de la cour? [Aquela bicicletinha com guidom cromado no fundo do pátio?] (1966), La Boutique obscure (1973), Espèces d'espaces (1974), Je me souviens (1978) e La Vie mode d'emploi (1978) - obra que conta com um índice com 3000 entradas.

${ }^{407}$ Les index (pour lesquels Perec a une prédilection) permettent une circulation infinie dans les textes, relativisent leur structure apparente, tout en la laissant intacte, si un jour on édite Lieux, il faudra suivre cette indication. LEJEUNE. La mémoire et l'oblique, 1991, p. 201.

${ }^{408}$ WOOD. Arte Conceitual, 2002, p. 49.

${ }^{409}$ Para um detalhamento maior a respeito dessa obra, cf. DREHER. Index Systems. In: Blurting in A \& L. (2001/2002).

${ }^{410}$ WOOD. Op. cit., p. 49.
} 
resultados. Essa era uma nova maneira de entender o evento artístico e a sua apreensão. Como

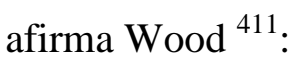

[...] essa prática de arte não teria como finalidade a produção de infinitos objetos que se colocassem a serviço do prazer estético, nem seria vista como o produto de um autor individual 'artístico'. [...] Significa, isso sim, conceber a arte como potencialmente um tipo de prática crítica, cognitiva e, acima de tudo, social, que pudesse permitir o alcance de uma autoconsciência crítica no mundo, influenciando, talvez, até mesmo, a construção de um tal mundo.

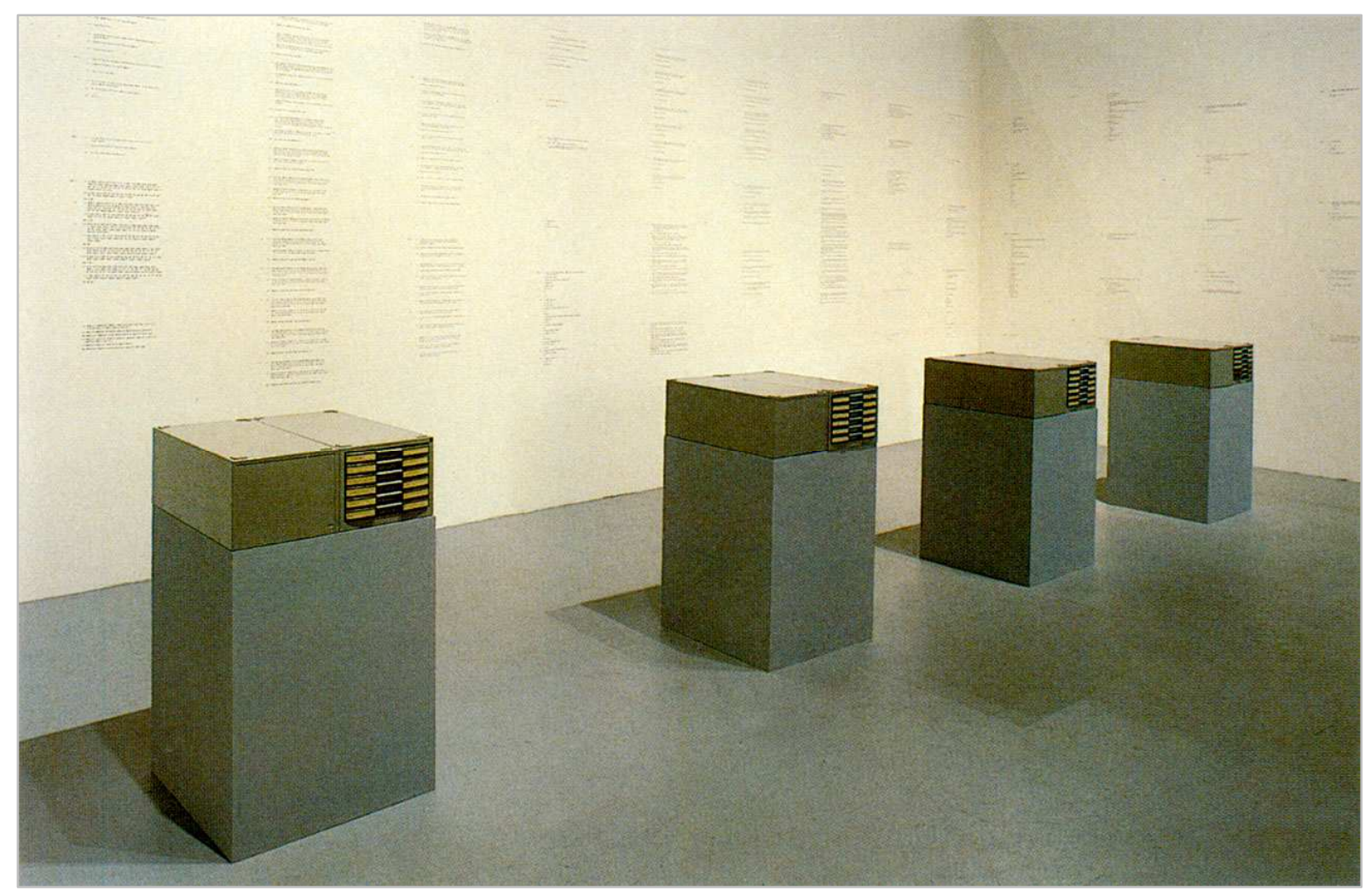

Figura 26 - Arte \& Linguagem. Índice 01 1972. Fotografia da Instalação na Galerie Nationale du Jeu de Paume, Paris, 1994.

Os artistas aqui rompiam com pelo menos três valores do que se entendia por obra de arte: primeiro, pela natureza da autoria, já que a obra era proposta por um grupo; segundo, pela natureza da obra, uma vez que eles não produziam um objeto e incitavam a produção de um Texto (para seguir a nomenclatura de Barthes indicada anteriormente); e terceiro, e mais importante, pela natureza do destinatário almejado pela iniciativa, um espectador/leitor ativo, um agente promotor de sentidos.

\footnotetext{
${ }^{411}$ WOOD. Arte Conceitual, 2002, p. 51.
} 
Derrida é um autor que, por motivações distintas daquelas que impulsionam esta pesquisa, tratou do conceito de arquivo em seu livro Mal de arquivo. Uma impressão freudiana $^{412}$. $\mathrm{Eu}$ tomo algumas dessas ideias para entender a potência dessa forma de sistematizar um conteúdo e propor algum tipo de conhecimento.

Segundo esse filósofo, o sentido de 'arquivo' vem do arkheîon grego

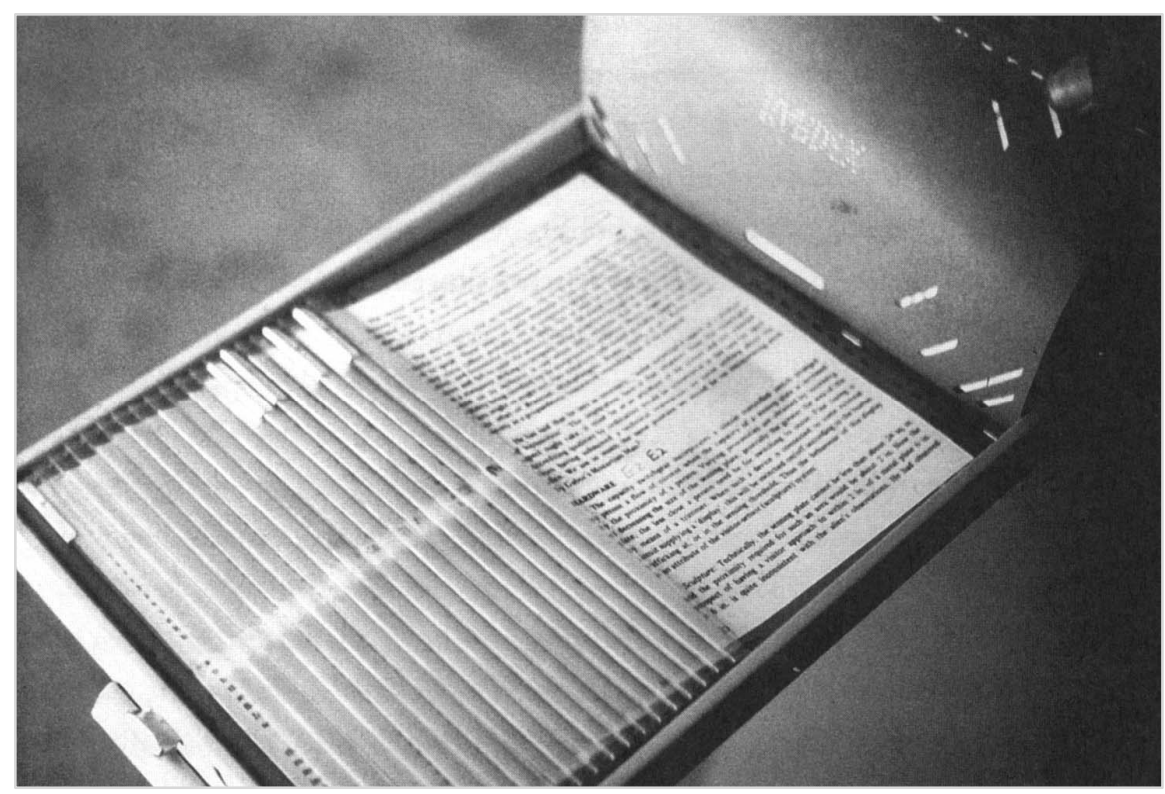

Figura 27 - Arte \& Linguagem. Índice 01 1972. Textos para consulta na gaveta do Arquivo (detalhe).

e indica a casa

onde moravam aqueles que tinham autoridade reconhecida para fazer ou representar a lei e onde se depositavam os documentos oficiais. Os arcontes, nome dos que guardavam os documentos oficiais, tinham o poder de interpretar os arquivos. Foi então nesse domicílio um lugar - e sob a responsabilidade de alguém - o arconte - que se formou a ideia de arquivo. Os documentos, ainda segundo Derrida ${ }^{413}$, habitam esse lugar por aquilo que ali é visível e invisível através da matéria e da autoridade. Mas isso ainda não é garantia do que existe em potência no arquivo: não basta haver uma acumulação de documentos sob a responsabilidade de alguém em um lugar particular, é preciso que tudo caminhe junto com o que o filósofo chama de 'consignação', ou seja, um princípio de reunião dos signos. Daí que Derrida ${ }^{414}$ afirma:

a consignação tende a coordenar um único corpus em um sistema ou uma sincronia na qual todos os elementos articulam a unidade de uma configuração ideal. Num arquivo, não deve haver dissociação absoluta, heterogeneidade ou segredo que viesse a separar [...], compartimentar de modo absoluto.

\footnotetext{
412 DERRIDA. Mal de arquivo, 2001.

${ }^{413}$ Ibidem, p. 13.

${ }^{414}$ Ibidem, p. 14.
} 
A questão do arquivo deve então lidar com esses três aspectos: o que se refere à materialidade dos documentos, o que valida a sua tutela e o que justifica o agrupamento de tudo - a 'consignação'. Mas há ainda um trabalho que está por ser feito e que irá conferir sentido a todo esse sistema: é o trabalho do pesquisador - no campo institucional - e do espectador/leitor interessado no campo da arte contemporânea. Derek Schilling ${ }^{415}$ cita duas ideias importantes de Arlette Farge ${ }^{416}$ para a compreensão do papel desses agentes externos ao arquivo: a qualidade móvel e imprevisível do arquivo em oposição à rigidez do texto impresso $^{417}$ e a condição de estar constantemente em falta do arquivo ${ }^{418}$, o que sempre exige a intervenção de um agente externo capaz de formular o que o documento não pode formular por si.

Se Perec tivesse ido até o final com Lieux, se tivesse adotado a forma de arquivo, se tivesse preparado o sonhado índice e se tivesse confiado a seus leitores a tarefa de encontrar ali algum sentido - o seu trabalho já estaria cumprido. Não foi o que ocorreu: no lugar do projeto utópico de doze anos, ele se lançou num projeto factível de três dias, ao invés de uma cápsula do tempo, ele preferiu o esgotamento de um lugar e, ao invés de um título enfático como Lieux, ele optou por uma aproximação cuidadosa: Tentative d'épuisement d'un lieu parisien [Tentativa de esgotamento de um lugar parisiense].

\footnotetext{
${ }^{415}$ SCHILLING. Mémoires du quotidien: les lieux de Perec, 2006.

${ }^{416}$ FARGE, Arlette. Le goût de l'archive. Paris: Seuil, 1989.

${ }^{417}$ FARGE. Op. cit., p. 12, apud SCHILLING. Op. cit., 172.

${ }^{418}$ FARGE. Op. cit., p. 70, apud SCHILLING. Op. cit., 172.
} 


\section{4. (Não)Lugares manual de instruções}

O cotidiano não está no calor de nossos lares, não está nos escritórios nem nas igrejas, nem tampouco nas bibliotecas ou nos museus. Está - se estiver em algum lugar - na rua.

Maurice Blanchot ${ }^{419}$

Lieux está completo apenas em estado de projeto, só nessa situação ele faz sentido, só na sua integralidade de fantasia é possível justificar as partes e compreender a ideia que lhe serve de base. Incompleto, nem seu título faz sentido, pois os textos escritos in situ por Perec e batizados como 'lugares' não chegam a identificar esses espaços como tais, são apenas campos de deambulação de onde se recolhem coisas que deverão ser guardadas em forma de escrita. Talvez isso ficasse esclarecido ao final do projeto, quando o autor poderia enfim, por meio de descrições exaustivas e muitas lembranças, designar/recompor quais eram exatamente os lugares que haviam enfim atraído ao longo de tanto tempo sua atenção, seu desejo, sua lembrança, sua repulsa.

Isso não ocorreu e Perec continuou a designar como 'lugar' outro espaço de pesquisa no qual ele buscou identificar 'o que acontece quando não acontece nada': a place SaintSulpice. Encontrei também em Euvres - o campo dos possíveis de Édouard Levé um lugar semelhante a esse de Perec: é Angoisse.

Os grandes projetos utópicos - Lieux para Perec, e Euvres para Levé - compuseram os arquivos a partir dos quais seus autores puderam realizar respectivamente Tentative d'épuisement d'un lieu parisien e Angoisse.

${ }^{419}$ BLANCHOT. A fala cotidiana. In: . A conversa infinita, 2007, pp. 241-242. 


\subsubsection{Tentative d'épuisement d'un lieu parisien: uma escrita fotográfica}

A rua é o lugar das 'coisas comuns', o viveiro da memória coletiva. ${ }^{420}$

Philippe Lejeune

Em outubro de 1974, quando Perec ainda não havia desistido do projeto de Lieux, mas para o qual ele não produzira nenhum texto havia dezoito meses, ele decide ir à place SaintSulpice (lugar que não fazia parte de Lieux) e descrevê-la ao longo de três dias seguidos (18, 19 e 20 de outubro) a partir de três cafés diferentes - seus postos de observação. Mesmo que o exercício de ir até esse lugar na cidade de Paris para descrevê-lo in situ se pareça com o que ele começara a fazer em Lieux, esse esforço não é a continuação daquele projeto, mas um desvio. Lejeune destaca que com essa nova iniciativa de Perec, ele estava desconsiderando as duas contraintes iniciais: aquela que determinava que para cada real havia também uma lembrança, e aquela que havia determinado uma contrainte temporal para o projeto. Essa nova iniciativa se resumiria a três dias - uma sexta-feira, um sábado e um domingo -, receberia o título de Tentative d'épuisement d'un lieu parisien e seria publicada primeiramente na revista Cause commune em 1975 e, posteriormente, em livro ${ }^{421}$.

Esse novo trabalho é explicado pelo autor no início do texto:

Há muitas coisas na place Saint-Sulpice, por exemplo: há uma subprefeitura, uma secretaria de finanças, um posto de polícia, três cafés sendo um deles tabacaria, um cinema, uma igreja [...], um editor, uma agência funerária, uma agência de viagens, uma parada de ônibus, um alfaiate, um hotel, uma fonte decorada com as estátuas dos grandes oradores católicos (Bossuet, Fénelon, Fléchier e Massillon), uma banca de jornais, um vendedor de objetos religiosos, um estacionamento, um salão de beleza, e muitas outras coisas ainda.

Um grande número, senão a maior parte, dessas coisas foram descritas, inventariadas, fotografadas, contadas ou recenseadas. Meu propósito nas páginas que seguem foi mais precisamente de descrever o resto: isso que geralmente não se percebe, isso que não se nota, isso que não tem importância: isso que acontece quando não acontece anda, a não ser o tempo, as pessoas, os carros e as nuvens. ${ }^{422}$ (Telp, pp. 9-10)

${ }^{420}$ La rue est le lieu des "choses communes", le vivier de la mémoire collective. LEJEUNE. La mémoire et l'oblique, 1991, p. 238.

${ }^{421}$ PEREC. Tentative d'épuisement d'un lieu parisien, 2008.

${ }^{422}$ Il y a beaucoup de choses place Saint-Sulpice, par exemple: une mairie, un hôtel des finances, un commissariat de police, trois cafés dont un fait tabac, un cinéma, une église [...], un éditeur, une entreprise de pompes funèbres, une agence de voyages, un arrêt d'autobus, un tailleur, un hôtel, une fontaine que décorent les statues des quatre grands orateurs chrétiens (Bossuet, Fénelon, Fléchier et Massillon), un kiosque à journaux, un marchand d'objets de piété, un parking, un institut de beauté, et bien d'autres choses 
É bom lembrar que esse exercício de filtragem do desimportante ou, esse exercício de "criação negativa" - como definiu Lejeune -, já vinha sendo trabalhado por Perec na escrita de Je me souviens desde 1973: filtrar tudo o que fosse pessoal e subjetivo para deixar passar e registrar unicamente o que fosse compartilhável, comum, banal, e que, no caso da praça, mesmo sendo um espaço público, deveria ainda assim ser invisível à maioria.

Para registrar esse traço do banal, a escrita não poderia ser diferente e deveria acompanhar o mesmo estatuto do que se via, ou seja, ser neutra, pura denotação, simples constatação. Para isso a escrita de Perec deveria abandonar o que Francblin reconhece como um exercício pessoal do fazer para se dedicar ao exercício anônimo do recolher - impondo a si um novo tipo de distanciamento com relação à obra.

No mesmo ano que Perec vai à place Saint-Sulpice para descrever o que vê, ele publica Espèces d'espaces - obra que é um grande e diversificado arquivo de espaços (o que também faz pensar em CEuvres, de Levé). É nesse livro que Perec apresenta um manual de instruções para interrogar o espaço, ou, ainda mais simples, para 'ler' o espaço da rua. Esse manual é chamado por Perec de: Travaux pratiques [Trabalhos práticos] e traz muitas indicações que parecem ter orientado a escrita de Tentative d'épuisement d'un lieu parisien:

\footnotetext{
Observar a rua, de tempos em tempos, talvez com uma preocupação um tanto sistemática.

Se esforçar.

$[\ldots]$

Anotar o que se vê. O que se passa de notável. Sabemos ver o que é notável? Há alguma coisa que nos atinge?

Nada nos atinge. Nós não sabemos ver.

É necessário ir à frente mais devagar, de um jeito um pouco estúpido. Se forçar a escrever o que não têm interesse, o que é o mais evidente, o mais comum, o mais terno. ${ }^{423}$ (Ee, p. 70)
}

Parece paradoxal, mas desde o início da relação de Perec com o OuLiPo, ele nunca se interessou por aquilo que era o objetivo maior do grupo: pesquisar antigas e novas estruturas que permitissem ampliar as possibilidades da literatura em potencial, e não, produzir exatamente 'literatura' (a produção literária para os oulipianos era uma consequência do

encore. / Un grand nombre, sinon la plupart, de ces choses ont été décrites, inventoriées, photographiées, racontées ou recensées. Mon propos dans les pages qui suivent a plutôt été de décrire le reste: ce que l'on ne note généralement pas, ce qui ne se remarque pas, ce qui n'a pas d'importance: ce qui se passe quand il ne se passe rien, sinon du temps, des gens, des voitures et des nuages.

${ }^{423}$ Observer la rue, de temps en temps, peut-être avec un souci un peu systématique. / S'ppliquer. Prendre son temps. / [...] / Noter ce que l'on voit. Ce qui se passe de notable. Sait-on voir ce qui est notable? Y a-t-il quelque chose qui nous frappe? / Rien ne nous frappe. Nous ne savons pas voir. / Il faut y aller plus doucement, presque bêtement. Se forcer à écrire ce qui n'a pas d'intérêt, ce qui est le plus évident, le plus commun, le plus terne. 
trabalho deles no grupo, e não um objetivo). Como salienta Bernard Magné ${ }^{424}$, o Perec oulipiano sempre privilegiou o exercício da escrita e seu trabalho físico/material em detrimento da elaboração teórica, intelectual, virtual, das contraintes, se colocando em oposição ao que François Le Lionnais, citado por Magné, pregava com insistência: "Não se esqueça [...] que o método se basta por si mesmo. Existem métodos sem exemplos. O exemplo é um prazer que se dá a mais - e que se dá ao leitor." ${ }^{425}$ Mas com Espèces d'espaces - estruturado segundo Burgelin ${ }^{426}$ como um sistema de encaixes à maneira de bonequinhas russas e que não tem qualquer relação com o trabalho com o OuLiPo - Perec chega a um campo de reflexões que lhe permitiu criar um 'método de aproximação do banal' e que tem em Tentative d'épuisement d'un lieu parisien um exercício prático .

Entre outras regras presentes em Travaux pratiques que permitem questionamentos, reflexões e uma 'escrita do espaço', eu destaco estas que parecem repercutir algumas das ideias de Sei Shônagon:

Não dizer, não escrever “etc.". Se esforçar por esgotar o assunto, mesmo que isso tenha o ar grotesco, ou fútil, ou estúpido. Ainda não vimos nada, apenas identificamos o que já havíamos identificado há muito tempo.

Obrigar-se a ver de maneira mais direta. ${ }^{427}(\mathrm{Ee}, \mathrm{p} .71)$

Nesse texto, a aproximação do cotidiano sugerida por Perec é pontual, desarticulada e minuciosa, e desenvolve o que ele já havia escrito quase na mesma época em Approches de quoi? ${ }^{428}$. A ideia é desmembrar o real, tomá-lo por partes e assim quebrar a cadeia de sentidos que faz com que no conjunto tudo se torne invisível:

\footnotetext{
${ }^{424}$ MAGNÉ. Georges Perec, l'oulibiographe. In: Magazine Littéraire, no 398, 2001, p. 53.

${ }^{425}$ N'oubliez pas [...] que la méthode se suffit à elle-même. Il y a des méthodes sans exemple. L'exemple est un plaisir que l'on se donne en plus - et que l'on donne au lecteur. François Le Lionnais apud MAGNÉ. Op. cit., p. 53.

Nessa relação dos oulipianos com a contrainte, Magné compara alguns trabalhos de Perec feitos no OuLiPo com aqueles feitos por Queneau, salientando que, enquanto Queneau apresentava a contrainte junto com algumas amostras do seu uso, deixando que o leitor continuasse por si, Perec, obsessivo no seu desejo de compor um inventário exaustivo; optava por explorar ao máximo o uso da contrainte, até que ele tomasse por encerrada aquela possibilidade de escrita e pudesse mudar de jogo - tal como um brinquedo, ou, uma máquina.

${ }^{426}$ BURGELIN. Georges Perec, 2002, p. 121.

${ }^{427} \mathrm{Ne}$ pas dire, ne pas écrire “etc.”. Se forcer à épuiser le sujet, même si ça a l'air grotesque, ou futile, ou stupide. On n'a encore rien regardé, on n'a fait que repérer ce que l'on avait depuis longtemps repéré. I S'obliger à voir plus platement.

${ }^{428}$ Cf. item 2.1.2.1.
} 
Continuar

Até que o lugar se torne improvável

até ter por um breve instante a impressão de estar em uma cidade estranha, ou, melhor ainda, até não entender mais o que acontece ou, o que não acontece, que o lugar por completo se torne estranho, que nem se saiba mais que isso se chama cidade, rua, prédios, calçadas... ${ }^{429}$ (Ee, pp. 73-74)

Ao escolher ir à place Saint-Sulpice na sexta-feira, sábado e domingo, Perec definia de modo rápido e eficiente uma variação temporal que permitia que ele se lembrasse do que havia anotado anteriormente e pudesse assim se concentrar no que ainda não havia observado/anotado. Atento e rápido, Perec precisava educar e adequar seu olhar a uma escrita ágil e econômica para que, no plano das ações simultâneas que tinha à sua frente, conseguir esquadrinhar, apreender, selecionar e registrar apenas o essencial: o infraordinário ${ }^{430}$.

De maneira diversa ao que ocorria em Lieux, quando Perec fazia geralmente suas anotações em pé e andando, em Tentative d'épuisement d'un lieu parisien o autor permaneceu quase sempre sentado e, na maioria das vezes, com o apoio de uma mesa. Apesar desse conforto, o texto apresenta um estranhamento no emprego de várias convenções da escrita como, por exemplo:

no uso arbitrário de maiúsculas e minúsculas no início de cada frase:

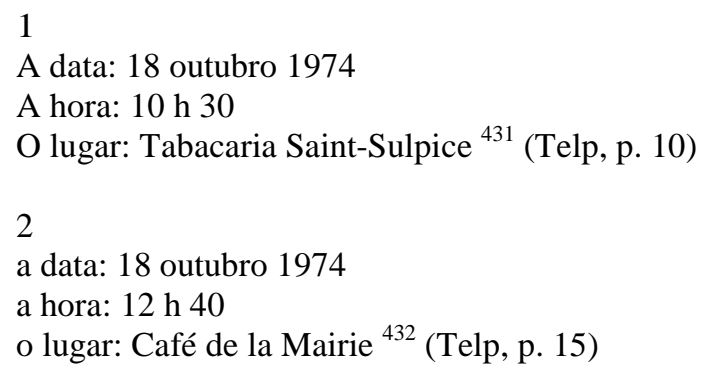

no uso irregular da pontuação e no emprego de minúscula após o ponto na primeira linha:

Um ônibus de viagem, vazio.

${ }^{429}$ Continuer / Jusqu'à ce que le lieu devienne improbable / jusqu'à ressentir, pendant un très bref instant, l'impression d'être dans une ville étrangère, ou, mieux encore, jusqu'à ne plus comprendre ce qui se passe ou ce qui ne se passe pas, que le lieu tout entier devienne étranger, que l'on ne sache même plus que ça s'appelle une ville, une rue, des immeubles, des trottoirs ...

${ }^{430}$ Cf. a tradução de um trecho de Tentative d'épuisement d'un lieu parisien no item 3.4.1.1.

Decidi incluir na pesquisa a tradução de uma seção inteira dessa obra para que o leitor tivesse um contato direto com um corpo maior desse texto, já que nenhuma citação daria a dimensão justa das variáveis, das repetições e dos estranhamentos que só uma experiência mais extensa de leitura do texto perequiano poderia propiciar.

${ }^{431} 1$ / La date: 18 octobre 1974 / L'heure: 10 h 30 / Le lieu: Tabac Saint-Sulpice

${ }^{432} 2$ /la date: 18 octobre 1974 /l'heure: 12 h 40 /le lieu: Café de la Mairie 
outros japoneses em outro carro

O 86 vai a Saint-Germain-des-Prés

Braun reproduções de arte

Acalmia (lassidão ?)

Pausa. $^{433}$ (Telp, p. 15)

na construção variada de frases longas, curtas e muito curtas, com e sem sinais gráficos para expor o mesmo conteúdo:

\author{
O 63 vai à Porte de la Muette ${ }^{434}$ (Telp, p. 12) \\ Um 63 passa. Um 87 passa. ${ }^{435}$ (Telp, p. 16) \\ Um 63 passa ${ }^{436}$ (Telp, p. 18) \\ Um $63^{437}$ (Telp, p. 18) \\ Um 63. ${ }^{438}$ (Telp, p. 22) \\ Passa um 63 quase cheio ${ }^{439}$ (Telp, p. 28) \\ Passa um 63 ele está cheio ${ }^{440}$ (Telp, p. 30) \\ Passa um $63^{441}$ (Telp, p. 44) \\ Passagem de um ônibus $63^{442}$ (Telp, p. 45) \\ Passagem de um $63^{443}$ (Telp, p. 46) \\ O $63^{444}$ (Telp, p. 48)
}

Um 63 que para excepcionalmente na esquina da rue des Canettes para deixar descer um casal de idosos ${ }^{445}$ (Telp, p. 49)

${ }^{433}$ Un car, vide. / d'autres Japonais dans un autre car / Le 86 va à Saint-Germain-des-Prés / Braun reproductions d'art / Accalmie (lassitude?) / Pause.

${ }^{434}$ Le 63 va à la Porte de la Muette

${ }^{435}$ Un 63 passe. Un 87 passe.

${ }^{436}$ Un 63 passe

${ }^{437}$ Un 63

${ }^{438}$ Un 63.

${ }^{439}$ Passe un 63 presque plein

${ }^{440}$ Passe un 63 il est plein

${ }^{441}$ Passe un 63

${ }^{442}$ Passage d'un autobus 63

${ }^{443}$ Passage d'un 63

${ }^{444}$ Le 63

445 Un 63 qui s'arrête exceptionnellement au coin de la rue des Canettes pour laisser descendre un couple de gens âgés 
na movimentação dos parágrafos com relação à margem:

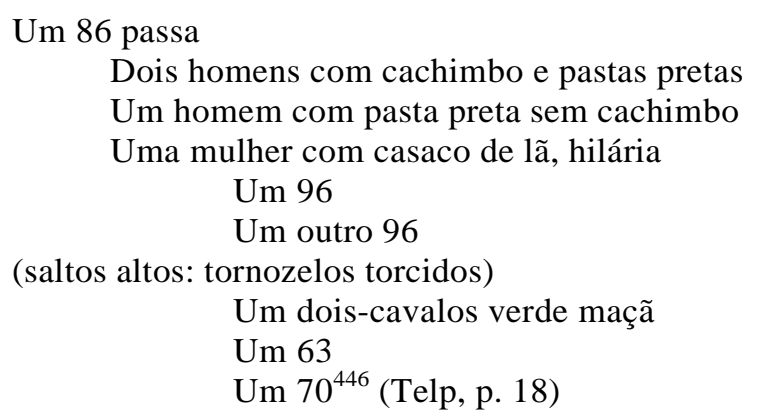

e, por fim, na variação da maneira de representar as horas misturando algarismos arábicos e palavras, além do uso irregular de minúscula e da supressão do ponto final:

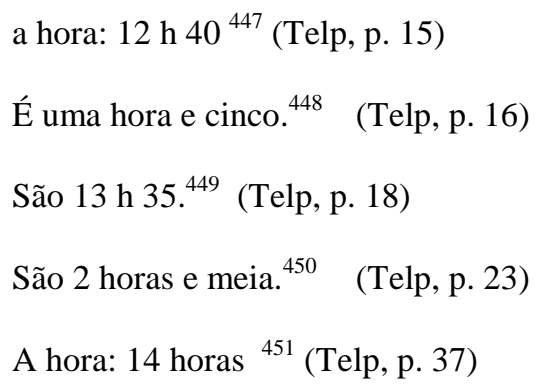

Todas essas observações absolutamente insignificantes passam despercebidas numa leitura apressada de Tentative d'épuisement d'un lieu parisien, mas à medida que tentamos enfrentar o texto de modo semelhante ao que fez Perec com relação à praça - olhando com atenção o insignificante -, descobrimos (e compartilhamos) a sua experiência de perceber: “isso que geralmente não se percebe, isso que não se nota, isso que não tem importância: isso que acontece quando não acontece anda [...]." (já citado no início deste item). Da mesma forma que Perec se colocava em diferentes pontos da praça para observar 'o que acontece quando não acontece nada' e assim identificar o irrisório, o leitor também pode simular essa experiência ao reconhecer diferentes aspectos na materialidade do texto (mesmo

\footnotetext{
${ }^{446}$ Un 86 passe / Deux hommes à pipe et sacoches noire / Un homme à sacoche noire sans pipe / Une femme en veste de laine, hilare / Un 96 / Un autre 96 / (talons hauts: chevilles tordues) / Une deuxchevaux vert pomme / Un 63 / Un 70

447 l'heure: 12 h 40

${ }^{448}$ Il est une heure cinq.

${ }^{449}$ Il est 13 h 35.

${ }^{450}$ Il est 2 heures et demie

${ }^{451}$ L'heure: 14 heures
} 
num evento repetitivo, como é a passagem dos ônibus, existe a interferência de outras forças sobre a apreensão/registro do fato observado). Esse texto, tomado por fragmentos estranhos, passa a ser a fenda pela qual se ingressa no universo do comum, pois, como afirma Perec: "Para ver alguma coisa no cotidiano, é necessário um rasgo" ${ }^{452}$. E todas essas insignificâncias na materialidade do texto - um tipo de real concreto - podem ser entendidas como um efeito de banal na criação de um trompe-l'œeil textual do banal cotidiano ${ }^{453}$.

Ainda sobre a materialidade do texto de Perec, é fácil notar que ele é tomado pelo que é numerável: datas, horários, códigos (números de ônibus, por exemplo), quantidades, números das seções do livro, páginas etc. Pela Tabela 3 é possível identificar a quantidade de páginas de texto (segundo o livro impresso) que Perec produziu em cada um dos dias: na sexta-feira (dia útil) foram vinte e três páginas; já, no sábado (dia misto) foram onze páginas; e, por fim, no domingo (dia de descanso) foram apenas seis. Isso evidencia que o texto de Perec está atrelado àquilo que é móvel e, portanto, passageiro, daí sua atenção aos ônibus, carros e pessoas que cruzam a praça em maior movimento na sexta-feira - Perec não se interessa em observar e descrever detalhadamente os aspectos físicos da praça, da fonte, da igreja ou mesmo dos edifícios ao redor já que, como ele escreve na introdução, isso já havia sido feito.

A opção de Perec é esclarecedora para o que ele compõe com seu texto e que, em primeiro lugar, não é da ordem do lugar, mas do espaço. E porque não é lugar? Segundo Michel de Certeau ${ }^{454}$ um lugar é onde impera a condição do que é 'próprio': “os elementos considerados se acham uns ao lado dos outros, cada um situado no lugar 'próprio' e distinto que define. Um lugar é portanto uma configuração instantânea de posições. Implica uma indicação de estabilidade”. Ainda que seja possível entender a place Saint-Sulpice como um

452 Pour voir quelque chose dans le quotidien, il y faut une déchirure. PEREC. ___ • "Pour Georges Perec, le banal est explosif." (1979). In: Entretiens et Conférences, 2003b, p. 83.

${ }^{453}$ Perec era fascinado pelas possibilidades de enganar o observador através do trompe-l'œil. Para que isso pudesse ser plenamente realizado, Perec nota que não seria unicamente por meio de uma técnica apuradíssima onde tudo estaria em ordem e seguisse os mais altos padrões de correção e beleza que o truque do real poderia efetivamente se concretizar: para enganar o observador faltaria ainda incorporar ao plano da fantasia e da técnica algo que trouxesse o trabalho para o mesmo plano da vida, ou seja, para o plano da imperfeição. Os artistas que conseguiam isso sabiam incorporar às suas obras o que também designa a desordem, o gasto, a usura e o imperfeito. Cf. PEREC; WHITE. L'oeil ébloui, 1987, s/ nº p..

${ }^{454}$ CERTEAU. A invenção do cotidiano, 2009, p. 184. 
lugar muito 'próprio', visto que é demarcado, estável e localizável, não é para isso que Perec olha e não é isso o que ele constrói com seu texto: além de mudar sua posição de observação várias vezes ao longo dos três dias, a maior parte das coisas que chamam sua atenção também se encontra em movimento: olhando para a praça, Perec só vê o que não é praça. Já, quanto ao espaço, Certeau afirma que o espaço existe sempre que são levados em conta vetores de direção, quantidades de velocidade e a variável tempo. "O espaço", escreve Certeau 455 , "é um cruzamento de móveis", ou ainda: "o espaço é um lugar praticado", salientando que existem tantos espaços quantas experiências individuais forem realizadas com o mundo.

\begin{tabular}{|c|c|c|c|c|c|}
\hline \multicolumn{6}{|c|}{ Tabela 3} \\
\hline \multicolumn{6}{|c|}{ As seções de Tentative d'épuisement d'un lieu parisien } \\
\hline & Seção & Dia & Hora & Posto de observação & páginas \\
\hline \multirow{4}{*}{ 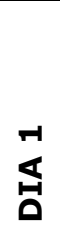 } & 1 & 18 out. 1974 & $10: 30$ hs & Tabac Saint-Sulpice & $10-15$ \\
\hline & 2 & 18 out. 1974 & $12: 40$ hs & Café de la Mairie & $15-23$ \\
\hline & 3 & 18 out. 1974 & $15: 20$ hs & Fontaine Saint-Sulpice (café) & $23-27$ \\
\hline & 4 & 18 out. 1974 & $17: 10$ hs & Café de la Mairie & $27-33$ \\
\hline \multirow{3}{*}{$\begin{array}{l}N \\
\mathbb{S}\end{array}$} & 5 & 19 out. 1974 & $10: 45$ hs & Tabac Saint-Sulpice & $33-36$ \\
\hline & 6 & 19 out. 1974 & $12: 30$ hs & banco & $36-37$ \\
\hline & 7 & 19 out. 1974 & $14: 00$ hs & Tabac Saint-Sulpice & $37-44$ \\
\hline \multirow{2}{*}{$\stackrel{m}{\mathbb{M}}$} & 8 & 20 out. 1974 & $11: 30$ hs & Café de la Mairie & $44-48$ \\
\hline & 9 & 20 out. 1974 & $13: 05$ hs & Café de la Mairie & $48-50$ \\
\hline
\end{tabular}

Com relação à place Saint-Sulpice, Perec desenvolve basicamente uma relação voyeurística, sem que se perceba ali qualquer cumplicidade ou intimidade, muito pelo contrário, ali ele parece se comportar como um viajante curioso. Encontro então em outro autor, Marc Augé ${ }^{456}$, uma definição que traz melhores esclarecimentos sobre a natureza do que Perec observa na place Saint-Sulpice e que diz respeito ao que fazem outros artistas interessados pelo banal do cotidiano: o trabalho com o 'não-lugar'. Em oposição ao 'lugarantropológico', que tem por características comuns ser identitário, relacional e histórico, e que eu entendo como um correlato do objeto-biográfico definido por Violette Morin, Marc Augé

\footnotetext{
${ }^{455}$ CERTEAU. A invenção do cotidiano, 2009, p. 184.

${ }^{456}$ AUGÉ. Não-Lugares, 2001.
} 
chama de 'não-lugar' o lugar que não traz nenhuma dessas características (ele também esclarece que esse tipo de polaridade nunca é total).

O arquétipo do não-lugar, ainda sob o ponto de vista de Augé, é exatamente o espaço do viajante e pode ser reconhecido por duas realidades complementares distintas: são espaços constituídos em relação a certos fins (transporte, trânsito, comércio, lazer) e são espaços constituídos pela relação que os indivíduos em estado de movimento mantêm com esses espaços. O que é possível dizer agora sobre Tentative d'épuisement d'un lieu parisien é que a place Saint-Sulpice não é um não-lugar por si, mas que é tratada por Perec, que só tem olhos para o que ali é móvel e passageiro, como um não-lugar lugar de passagem, do movimento e da desatenção, do uso coletivo anônimo, espaço das ambiguidades e do informe. "Assim é o confuso cotidiano", como escreve Blanchot ${ }^{457}$.

Por último, existe ainda
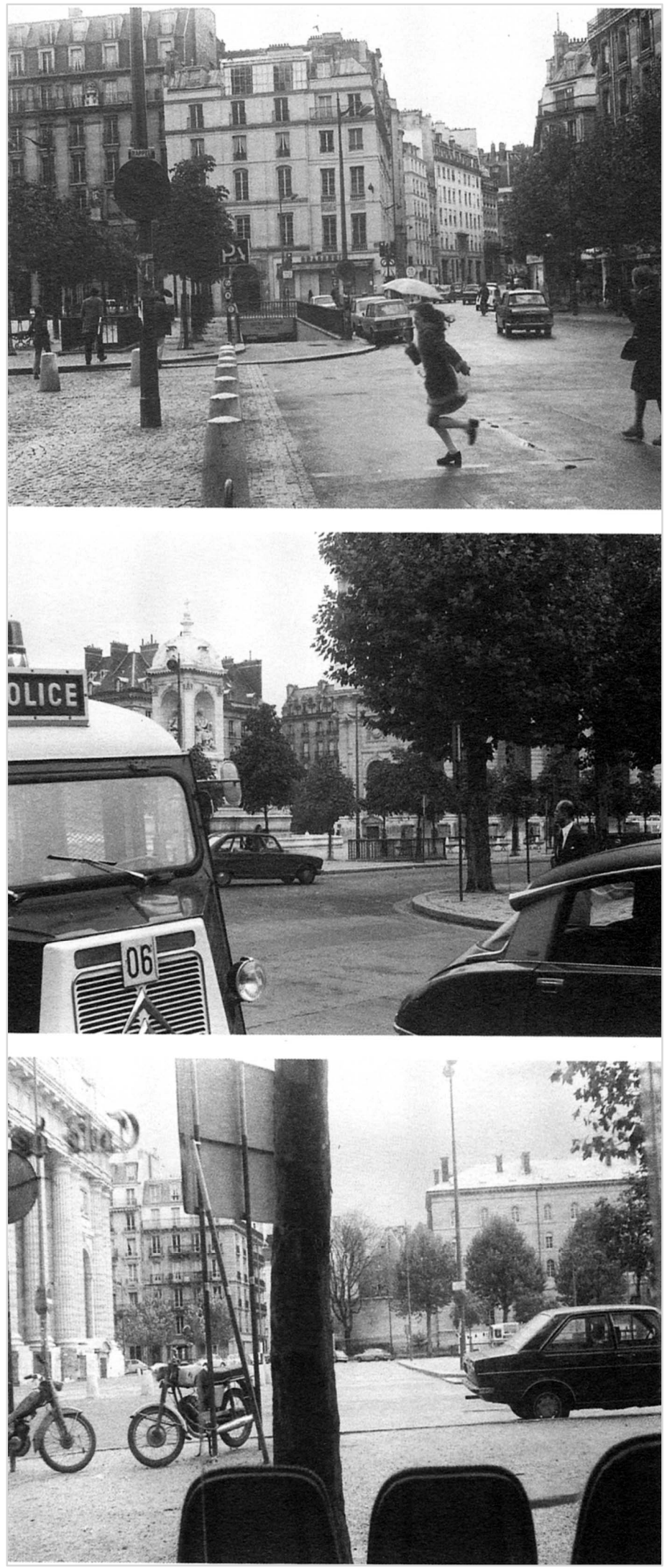

Figura 28 - Pierre Getzler. Place Saint-Sulpice, 1974, (fotografias).

${ }^{457}$ BLANCHOT. A fala cotidiana. In: A conversa infinita, 2007, p. 240. 
algo da forma adotada por Perec para seu texto que tomo como relevante para o entendimento da sua aproximação com o banal: é a presença subliminar da fotografia.

A fotografia está presente nesse trabalho de duas maneiras: como registro e como simulação na apreensão do mesmo real.

Ainda que as duas edições de Tentative d'épuisement d'un lieu parisien - a de 1975 na revista Cause commune, e a de 1982, como livro - não tragam qualquer imagem, no momento mesmo que Perec ia à place SaintSulpice durante três dias em 1974, seu amigo Pierre Getzler o acompanhava para fotografar ${ }^{458}$. O resultado é uma série de fotografias feitas ao redor da praça (fig. 28) e algumas fotografias de Perec trabalhando (fig. 29). Getzler afirma que havia sido chamado por Perec para fotografar as pessoas, os carros e tudo o mais que passava pela praça no momento em que ele escrevia, sem precisar que uso
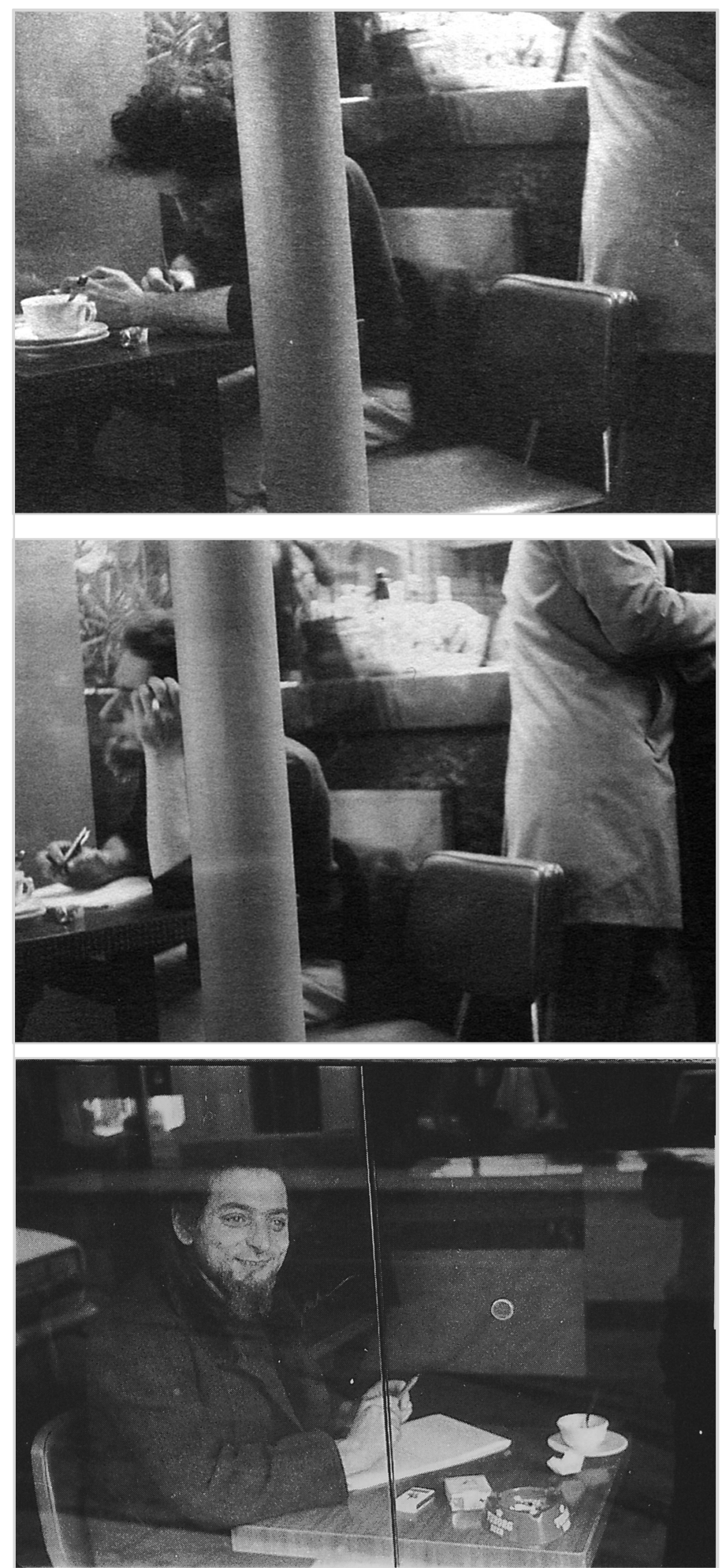

Figura 29 - Pierre Getzler, 'Café de la Mairie', place Saint-Sulpice, 1974, (fotografias).

${ }^{458}$ Pierre Getzler, amigo de muitos anos de Perec, é artista plástico e fotografou a pedido do amigo alguns dos lugares que faziam parte do projeto de Lieux, bem como acompanhou Perec à place Saint-Sulpice para fotografar o que se passava ali. O livro Espèces d'espaces é dedicado a ele. Cf. DEPAULE. $\underline{A}$ City in words and numbers. A conversation between Jean-Charles Depaule \& Pierre Getzler. In: AA Files 45/46, 2001, pp. 117-128. 
faria posteriormente desse material. Ele também autorizou Getzler a fotografá-lo enquanto escrevia e, mesmo sem ter qualquer comprovação do que Perec pretendia com isso, é possível entender essa forma paralela de registro como uma maneira de confirmar seu gesto de estar lá e de estar escrevendo (trabalhando). Desde os anos sessenta, muitos artistas envolvidos com experiências diretas com o real concreto buscavam confirmar seus gestos por algum tipo de registro, pois como enfatiza Arthur Danto ${ }^{459}$ : “quanto maior o grau de realismo pretendido maior a necessidade de indicadores externos de que se trata de arte e não de realidade, os quais se tornam tanto menos necessários quanto menos a obra é realista."

Nesse grupo de imagens que registram o trabalho do escritor - a efetivação da ideia a imagem que melhor explicita o que poderia ser uma tentativa de compor um simulacro fotográfico por meio da escrita é aquela em que Perec aparece olhando diretamente para o exterior do café. Ali, ele está sentado no interior do café e tem, entre ele e a praça, uma lâmina de vidro que faz o papel de janela: é o que se passa nesse plano - limite entre o dentro e o fora, superfície de projeção tanto das ações externas como das internas -, de onde Perec copia o que vê para depois transformar em escrita. Esse procedimento é explicado assim por Barthes:

Toda descrição literária é uma vista. Diríamos que o enunciador, antes de descrever, se coloca à janela, não exatamente para ver bem, mas para constituir o que ele vê por meio da sua moldura: o vão faz o espetáculo. Descrever é assim colocar a moldura vazia que o autor realista sempre carrega consigo [...], à frente de uma coleção ou um contínuo de objetos inacessíveis à palavra sem essa operação maníaca [...]; para poder falar do real, é necessário que o escritor, por um rito inicial, transforme antes de tudo, o "real" em objeto pintado (emoldurado); após o quê ele pode dependurar esse objeto, extraí-lo de sua pintura: em uma palavra: despintá-lo [...]. Desse modo o realismo [...] consiste, não em copiar o real, mas em copiar uma cópia (pintada) do real: esse famoso real [...]. ${ }^{460}$

É essa cópia-segunda que, no caso de Perec, passa por um processo de apagamento (tal como se fosse a antiga 'revelação do filme') que retira da imagem tudo o que ali é excepcional e extraordinário, deixando intacto apenas o ruído de fundo. Desse modo, a cada

\footnotetext{
${ }^{459}$ DANTO. A transfiguração do lugar-comum, 2005, p. 62.

${ }^{460}$ Toute description littéraire est une vue. On dirait que l'énonciateur, avant de décrire, se poste à la fenêtre, non tellement pour bien voir, mais pour fonder ce qu'il voit par son cadre même: l'embrasure fait le spectacle. Décrire, c'est donc placer le cadre vide que l'auteur réaliste transporte toujours avec lui [...], devant une collection ou un continu d'objets inaccessibles à la parole sans cette opération maniaque [...]; pour pouvoir en parler, il faut que l'écrivain, par un rite initial, transforme d'abord le "réel" en objet peint (encadré); après quoi il peut décrocher cet objet, le tirer de sa peinture: en un mot: le dépeindre [...]. Ainsi le réalisme [...] consiste, non à copier le réel, mais à copier une copie (peinte) du réel: ce fameux réel [...]. BARTHES. S/Z. In: Euvres Complètes, 2002c, pp. 163-164.
} 
novo posto de observação, com dia e hora marcada, e fazendo uso dos seus instrumentos de escrita, Perec compunha novas imagens por meio da sua escrita fotográfica. Como afirma Barthes em La chambre claire: “A vidência do Fotógrafo não consiste em 'ver', mas em se encontrar ali". 461

\subsubsection{Tradução: Seção 4, 18/10/1974, 17 h 10, Café de la Mairie}

A data: 18 de outubro 1974

A hora: $17 \mathrm{~h} 10$

O lugar: Café de la Mairie

A banca de jornais estava fechada; eu não encontrei Le Monde; eu realizei um circuito minúsculo (rue des Canettes, rue du Four, rue Bonaparte): belas ociosas invadem as lojas de roupas. Rue Bonaparte, eu olhei alguns títulos de livros em liquidação, algumas vitrines (mobiliário antigo e moderno, livros antigos, desenhos e gravuras)

Faz frio, me parece que cada vez mais

Estou sentado no Café de la Mairie, um pouco atrás em relação ao terraço

Passa um 86 ele está vazio

Passa um 70 ele está cheio

Passa, de novo, Jean-Paul Aron: ele tosse

Um grupo de crianças joga bola na frente da igreja

Passa um 70 bem vazio

Passa um 63 quase vazio

(porque contar os ônibus? Sem dúvida porque eles são reconhecíveis e regulares: eles cortam o tempo, eles dão ritmo ao barulho de fundo; no limite eles são previsíveis.

O resto parece aleatório, improvável, anárquico; os ônibus passam porque eles devem passar, mas nada quer que um veículo faça marcha a ré, ou que um homem tenha um saco marcado com o grande "M" de Monoprix, ou que um veículo seja azul ou maçã verde, ou que um cliente peça um café e não um copo de cerveja...)

Passa um 96 ele está quase vazio

O "P" do estacionamento e sua flecha se iluminam. Nos andares da Secretaria de finanças, os globos luminosos estão agora visíveis ${ }^{462}$ (Telp, pp. 27-29)

${ }^{461}$ La voyance du Photographe ne consiste pas à "voir" mais à se trouver là. BARTHES. La chambre claire. In: . Euvres complètes, 2002e, p. 827. 4624

La date: 18 octobre 1974 / L'heure: 17 h 10 / Le lieu: Café de la Mairie / Le kiosque à journaux était fermé; je n'ai pas trouvé Le Monde; j'ai accompli un minuscule circuit (rue des Canettes, rue du Four, rue Bonaparte): belles oisives envahissant des magasins de mode. Rue Bonaparte, j'ai regardé quelques titres de livres soldés, quelques devantures (mobilier ancien ou moderne, livres anciens, dessins et gravures) IIl fait froid, de plus en plus me semble-t-il / Je suis assis au Café de la Mairie, un tout petit peu en retrait par rapport à la terrasse / Passe un 86 il est vide / Passe un 70 il est plein / Passe, de nouveau, Jean-Paul Aron: il tousse / Un groupe d'enfants joue au ballon devant l'église / Passe un 70 plutôt vide / Passe un 63 
Passa um 70 ele está cheio

Passa um 63 ele está pouco

As motocicletas e as bicicletas motorizadas ligam seus faróis

Os pisca-piscas se tornam visíveis e mais visíveis ainda os luminosos dos táxis, mais brilhantes quando estão livres

Passa um 86 quase cheio

Passa um 63 quase vazio

Passa um 96 bem cheio

Passa um 87 bem cheio

(aplicar aos ônibus a teoria dos vasos comunicantes...)

São 17 h 50

Uma betoneira vermelho e azul, um Pyrénées empresa de táxis.

Passa um 96 ele está cheio

Passa um 86 ele está completamente vazio (só com o motorista)

Passa um 63 quase vazio

Passa um papai empurrando um carrinho de bebê

Mudanças da luz do dia

Um 87 quase vazio, um 86 meio cheio

As crianças jogam sob os pilares da igreja.

Um belo cachorro branco manchado de preto

Uma luz num imóvel (é o hotel Récamier?)

Um 96 quase vazio

Vento

Um 63 cheio, um 70 quase cheio, um 63 quase cheio

Um homem entra no café, se coloca na frente de um cliente que se levanta imediatamente e vai pedir a conta; mas ele não tem troco e é o outro que paga. Eles saem juntos.

Um homem quer entrar no café, mas ele começa a puxar a porta no lugar de empurrá-la

Fantasmagorias

Passa um 70 cheio

$$
\text { (cansaço) }{ }^{463} \text { (Telp, pp. 29-30) }
$$

Passa um 96 cheio pela metade

Novas luzes se acendem no café

Do lado de fora o crepúsculo está no auge

presque plein / (pourquoi compter les autobus? sans doute parce qu'ils sont reconnaissables et réguliers: ils / découpent le temps, ils rythment le bruit de fond; à la limite ils sont prévisibles. / Le reste semble aléatoire, improbable, anarchique; les autobus passent parce qu'ils doivent / passer, mais rien ne veut qu'une voiture fasse marche arrière, ou qu'un homme ait un sac marqué du grand "M" de Monoprix, ou qu'une voiture soit bleue ou vert pomme, ou qu'un consommateur commande un café plutôt qu'un demi...) / Passe un 96 il est presque vide / Le "P" du parking et sa flèche s'allument. Dans les étages de l'hôtel des finances, des globes lumineux sont maintenant visibles /

${ }^{463}$ Passe un 70 il est plein / Passe un 63 il l'est peu /Les motocyclettes et les vélomoteurs allument leurs phares / Les clignotants deviennent visibles et plus visibles aussi les voyants des taxis, plus brillants quand ils sont libres / Passe un 86 presque plein / Passe un 63 presque vide / Passe un 96 plutôt plein / Passe un 87 plutôt plein / (appliquer aux autobus la théorie des vases communicants ... ) / Il est 17 h 50 / Une bétonneuse rouge et bleue, un Pyrénées taxis transports. / Passe un 96 il est plein / Passe un 86 il est absolument vide (seulement le chauffeur) / Passe un 63 presque vide / Passe un papa poussant poussette / Modifications de la lumière du jour / Un 87 quasi vide, un 86 à moitié plein / Les enfants jouent sous les piliers de l'église. / Un beau chien blanc taché de noir / Une lumière à un immeuble (est-ce l'hôtel Récamier ?) / Un 96 quasi vide / Du vent / Un 63 plein, un 70 presque plein, un 63 presque plein / Un homme entre dans le café, se plante devant un consommateur qui se lève aussitôt et va pour régler sa consommation; mais il n'a pas de petite monnaie et c'est l'autre qui paie. Ils sortent ensemble. / Un homme veut entrer dans le café; mais il commence par tirer la porte au lieu de la pousser / Fantomatismes / Passe un 70 plein / (fatigue) 
Passa um 63 ele está cheio

Passa um homem empurrando seu solex

Passa um 70 ele está cheio

Passa um 96 cheio pela metade

Passam os ovos extra frescos NB

São cinco horas e cinquenta e cinco

De uma caminhonete azul um homem tirou um carrinho que ele carregou com diversos produtos de limpeza e que ele empurrou rue des Canettes. Do lado de fora não se distingue praticamente mais os rostos

As cores se fundem: acinzentado raramente iluminado

Manchas amarelas. Avermelhamentos.

Passa um 96 quase vazio

Passa um carro de polícia que vira na frente do átrio da igreja

Passa um 86 vazio, um 87 moderadamente cheio

Os sinos de Saint-Sulpice começam a tocar

Um 70 cheio, um 96 vazio, um outro 96 ainda mais vazio

Guarda-chuvas abertos

Os veículos automotores ligam seus faróis

Um 96 pouco cheio, um 63 cheio

$\mathrm{O}$ vento parece assoprar em rajadas, mas poucas viaturas fazem funcionar seus limpadores de para-brisas

Os sinos de Saint-Sulpice param de tocar (já eram as vésperas?)

Passa um 63 quase vazio

A noite, o inverno: aspecto irreal dos passantes

Um homem que carrega um tapete

Muita gente, muitas sombras, um 63 vazio; o piso está brilhando, um 70 cheio, a chuva parece mais forte. São seis horas e dez. Buzinadas; começo de engarrafamento $^{464}$ (Telp, pp. 30-31)

Eu mal consigo ver a igreja, em compensação, eu vejo praticamente todo o café (e eu mesmo escrevendo) no reflexo de seus próprios vidros

$\mathrm{O}$ engarrafamento se dissolveu

Os faróis só assinalam a passagem das viaturas

A iluminação pública vai sendo ligada progressivamente

Bem ao fundo (hotel Récamier?) há agora muitas janelas acesas

Passa um 87 quase cheio

Passa um homem que carrega uma moldura

Passa um homem que carrega uma prancha

Passa um carro de polícia sua luz azul giratória

Passa um 87 vazio, um 70 cheio, um 87 vazio

Pessoas correm

Passa um homem que carrega uma maquete de arquiteto (será mesmo uma maquete de arquiteto? Se parece com o que eu imagino ser uma maquete de arquiteto; eu não vejo o que mais poderia ser).

Passa uma betoneira laranja, um 86 quase vazio, um 70 cheio, um 86 vazio

Sombras indistintas

${ }^{464}$ Passe un 96 à moitié plein / De nouvelles lumières s'allument dans le café. / Dehors le crépuscule bat son plein / Passe un 63 il est plein / Passe un homme poussant son solex / Passe un 70 il est plein / Passe un 96 à moitié plein / Passent les oufs extra frais NB / Il est six heures moins cinq / D'une camionnette bleue un homme a sorti un diable qu'il a chargé de divers produits d'entretien et qu'il a poussé rue des Canettes. Dehors on ne distingue pratiquement plus les visages / Les couleurs fondent: grisaille rarement éclairée. I Taches jaunes. Rougeoiments. / Passe un 96 presque vide / Passe un car de police qui tourne devant le parvis de l'église / Passe un 86 vide, un 87 modérément plein / Les cloches de Saint-Sulpice se mettent à sonner / Un 70 plein, un 96 vide, un autre 96 encore plus vide / Des parapluies ouverts / Les véhicules automobiles allument leurs phares / Un 96 peu rempli, un 63 plein / Le vent semble souffler en rafales, mais peu de voitures font fonctionner leurs essuie-glaces / Les cloches de Saint-Sulpice s'arrêtent de sonner (était-ce les vêpres ?) / Passe un 63 presque vide / La nuit, l'hiver: aspect irréel des passants / Un homme qui porte des tapis / Beaucoup de monde, beaucoup d'ombres, un 63 vide; le sol est luisant, un 70 plein, la pluie semble plus forte. Il est six heures dix. Coups de klaxon; début d'embouteillage 
Um 96 cheio

(talvez só hoje eu tenha descoberto minha vocação: controlador das linhas de

São 18 h 45

ônibus da R.A.T.P)

Passam carangos

uma caminhonete amarela dos correios para na frente da caixa de correspondência que um carteiro descarrega do seu conteúdo duplo (Paris/fora-Paris, subúrbio incluído)

Chove sempre

Eu bebo uma genciana de Salers. ${ }^{465}$ (Telp, pp. 31-33)

\subsubsection{Angústia: uma fotografia literária}

$\mathrm{Na}$ angústia se manifesta um retroceder diante de... que sem dúvida, não é mais uma fuga, mas uma quietude fascinada. Este retroceder diante de... recebe seu impulso inicial do nada.

Martin Heidegger ${ }^{466}$

No livro Euvres, Édouard Levé detalha o projeto de um livro de fotografias:

[Obra $\left.\mathrm{n}^{\circ}\right] 55$. Um livro apresenta as entradas de municípios franceses cujo nome é ao mesmo tempo próprio e comum. A placa está no centro da imagem, a cidade aparece atrás. Trata-se de municípios, não de localidades ou de lugarejos. As letras são pretas sobre um fundo branco circundado por vermelho. A luz é neutra, difusa. A entrada do município chamado "VILLES" [CIDADES] é reproduzida na capa. Trezentas e oitenta páginas mostram, em cores, a entrada dos setecentos e trinta e nove municípios que seguem:

ABONDANCE [ABUNDÂNCIA], ABONDANT [ABUNDANTE], AGNEAUX [CORDEIROS], AIGUILlES [AGULHAS], AIME [AMO], AIRE [ÁREA], ALlEGRE [ALEGRE], ALLONS [VAMOS], ALTIER [ALTIVO], AMBRES [ÂMBAR], ANDOUILLE [CHOURIÇO, 'IMBECIL'], ANGE [ANJO], ANGLES [ÂNGULOS], ANGOISSE [ANGÚSTIA], [...]. ${ }^{467}$ (E, p. 27)

465 C'est à peine si je peux voir l'église, par contre, je vois presque tout le café (et moi-même écrivant) en reflet dans ses propres vitres / L'embouteillage s'est dissous / Les phares seuls signalent le passage des voitures / Les lampadaires s'allument progressivement / Tout au fond (hôtel Récamier?) il y a maintenant plusieurs fenêtres allumées / Passe un 87 presque plein / Passe un homme qui porte un cadre / Passe un homme qui porte une planche / Passe un car de police sa lampe bleue tournoyante / Passent un 87 vide, un 70 plein, un 87 vide / Des gens courent / Passe un homme qui porte une maquette d'architecte (est-ce vraiment une maquette d'architecte? Ça ressemble à l'idée que je me fais d'une maquette d'architecte; je ne vois pas ce que ça pourrait être d'autre). / Passe une bétonneuse orange, un 86 presque vide, un 70 plein, un 86 vide / Ombres indistinctes / Un 96 plein / (peut-être ai-je seulement aujourd'hui découvert ma vocation: contrôleur de lignes à la R.A.T.P.) / Il est 18 h 45 / passent des ouatures / une camionnette jaune des postes s'arrête devant la boîte aux lettres qu'un postier déleste de son double contenu (Paris/Hors-Paris, banlieue comprise) / Il pleut toujours /Je bois une gentiane de Salers.

${ }^{466}$ HEIDEGGER. Que é metafísica?, 1969, p. 34.

${ }^{467}$ 55. Un livre présente les entrées de communes françaises dont le nom est à la fois propre et commun. Le panneau est au centre de l'image, le village apparaît derrière. Il s'agit de communes, non de 
Segue então uma longa lista de seis páginas com nomes de cidades francesas. Dessa lista de cidades com nomes estranhos, Levé escolhe a cidade de Angoisse, localizada na Dordogne (sudoeste da França), para preparar o ensaio fotográfico (2001) que ele publica no livro Angoisse. Reconstitutions. O livro na verdade são dois livros em um: o ensaio Angoisse, feito com fotografias de paisagem urbana (exteriores e interiores) não tem qualquer relação, nem temática, nem pelas contraintes utilizadas, com a série Reconstitutions [Reconstituições], composta por fotos de estúdio com modelos ${ }^{468}$. O livro tem duas frentes: pela primeira tem-se Reconstitutions e, virando-se o livro (o que seria a contracapa de Reconstitutions) tem-se a capa de Angoisse. O livro apresenta ao centro dois textos que tratam de Reconstitutions: uma entrevista de Édouard Levé consigo mesmo ${ }^{469}$ e um ensaio de Quentin Bajac ${ }^{470}$. Sobre Angoisse, nem uma palavra.

A composição das imagens é semelhante ao que ocorre com as fotografias de Amérique, com a diferença que aqui o grau de assepsia é ainda maior, e de solidão também (fig. 30). As fotografias estão dispostas uma após a outra, sem intervalos, com uma fotografia por página e algumas fotografias em páginas duplas. A composição de todas as imagens é rígida e o espaço que elas exibem, além de ser desolador, tem um apelo cenográfico, o que faz pensar que algo pode acontecer. Mas nada acontece.

Como assinala Dominique Baqué ${ }^{471}$, esse ensaio de Édouard Levé é a continuação de uma série sobre o significante, em especial sobre o 'substantivo próprio' que o artista começou em 1999 com: Homonymes [Homônimos] ${ }^{472}$. Mais importante que o conteúdo das

lieux-dits ou de hameaux. Les lettres sont noires sur un fond blanc bordé de rouge. La lumière est neutre, diffuse. L'entrée de la commune appelée "VILLES" est reproduite sur la couverture. Trois cent quatre-vingts pages montrent, en couleur, l'entrée des sept cent trente-neuf communes suivantes:

ABONDANCE, ABONDANT, AGNEAUX, AIGUILLES, AIME, AIRE, ALLEGRE, ALLONS, ALTIER, AMBRES, ANDOUILLE, ANGE, ANGLES, ANGOISSE, [...].

${ }^{468}$ Os ensaios fotográficos que compõe a série Reconstitutions são: Rêves reconstitués [Sonhos reconstituídos], Actualités [Atualidades], Pornographie [Pornografia], Rugby e Quotidien [Rugby e Cotidiano]. O único desses ensaios que também faz parte de CEuvres é Pornographie, e corresponde à obra ${ }^{\circ} 149$.

469 LEVÉ. Interview d'Édouard Levé par lui-même. In : . Reconstitutions. Angoisse, 2008a, pp. 84-87.

${ }^{470}$ BAJAC. Le trouble du spectateur. In: LEVÉ. Op. cit., pp. 89-92.

${ }^{471}$ BAQUÉ. Photographie plasticienne, l'extrême contemporain, 2004, p. 59.

${ }^{472}$ Esse trabalho corresponde à obra no 77 incluída em Euvres. Ainda que sua realização seja anterior à publicação desse livro, ela também foi incluída entre as obras ainda por realizar. Esse trabalho consistia em buscar na lista telefônica homônimos de artistas e escritores admirados por Levé, fazer seus retratos e apresentá-los emoldurados junto com plaquetas de identificação em metal, colocadas logo abaixo do retrato. Desse modo, o artista pretendia "contrapor dois signos de identidade contraditórios: o rosto, desconhecido, e o nome, célebre”. Entre os retratados estão: Yves Klein, Eugène Delacroix, André Masson, e Henry Michaux. Cf. LEVÉ. Euvres, 2002, p. 38. 
imagens, o artista centrava o trabalho no estranhamento que surge na relação da imagem fotográfica com a palavra. Se em Homonymes essa relação dizia respeito a uma identidade emprestada, que obrigava o sujeito a carregar consigo uma história que não era sua, com Angústia ${ }^{473}$ ocorre a identificação de um lugar com uma palavra (antes de ser um 'nome') que evoca basicamente um incômodo.

A partir do momento que Levé definiu a ideia do trabalho, a única coisa que ele precisaria executar seria ir até Angústia para fotografar. Pode parecer paradoxal a declaração do fotógrafo que, mesmo saindo à rua para fotografar, afirma: "Eu trabalho a partir de princípios. Eu não improviso, eu preparo." ${ }^{474}$ É que no caso dele, ir à rua é uma tarefa a cumprir e não um exercício de busca e pesquisa. Da mesma forma que havia ocorrido com Perec em Lieux, o uso da contrainte era tanto um motivador como um controlador das forças empreendidas no trabalho e não servia para prever resultados.

Para que ao final o artista tivesse consigo um material que pudesse ser confrontado de maneira equilibrada, Levé empreendia um exercício de apagamento tanto da fotografia quanto do texto, buscando alcançar um grau-zero desses dois tipos de mensagens: a iconográfica (pela fotografia) e a verbal (pela legenda). Para isso Levé definia estratégias que lhe permitissem uma neutralidade perante o que fazia.

Antes de tratar da maneira como Levé consegue uma equivalência entre esses dois tipos de mensagens, é necessário ter em mente o que Jean Keim afirma sobre a relação da fotografia com sua legenda: "só, a fotografia não pode transmitir com segurança uma informação sem risco de um erro de interpretação e as palavras lhe são indispensáveis para lhe conferir um sentido verdadeiro sem contestação." ${ }^{475}$ E ele também especifica: "sua razão de existência [da legenda] em primeiro lugar é de precisar o sentido da imagem utilizada, seja a título de informação, seja a título de transmissão de uma mensagem [...]" e "[...] a fotografia apresenta, ela não conta [...]." 476

\footnotetext{
${ }^{473}$ A partir desse momento, traduzirei o nome da cidade de 'Angoisse' para 'Angústia' para manter o estranhamento que o artista propunha ao escolher essa cidade como tema do ensaio.

${ }^{474}$ Je travaille à partir de principes. Je n'improvise pas, je prépare. VILLENEUVE. Interview. In: Paris-Art, 2003.

$475[\ldots]$ seule, la photographie ne peut transmettre avec sûreté une information sans risque dune erreur d'interprétation et les mots lui sont indispensables pour lui conférer sans contestation un véritable sens. KEIM. La photographie et sa légende. In: Communications, 1963, p. 41.

${ }^{476}$ Sa raison d'existence en premier lieu est de préciser le sens de l'image utilisée, soit à titre d'information, soit à titre de transmission d'un message [...]. / [...] la photo présente, elle ne raconte pas [...]. Ibidem, p. 43.
} 


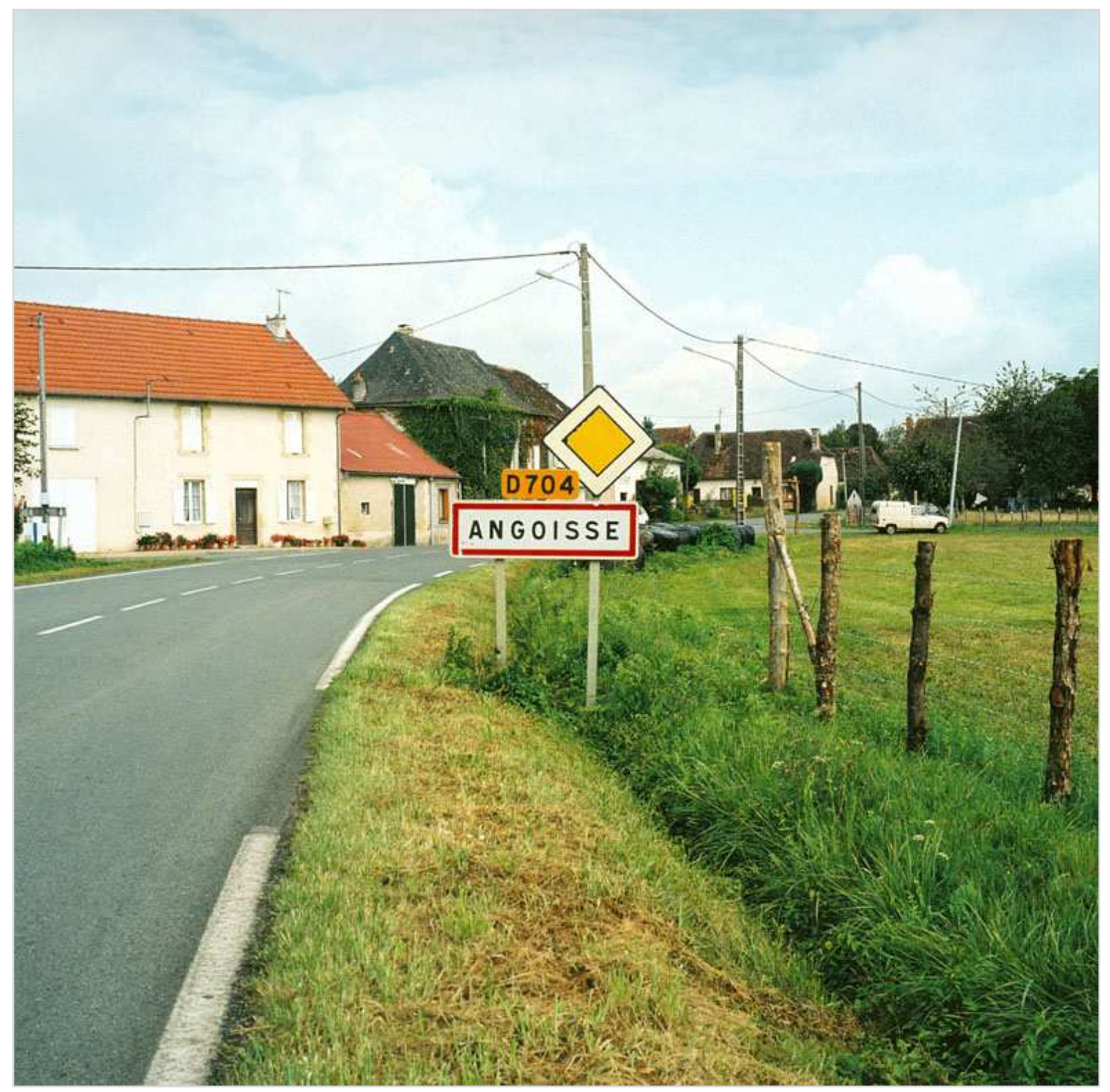

Figura 30 - Édouard Levé. Entrée d'Angoisse [Entrada de Angústia], fotografia.

Com exceção das fotografias em que o nome da cidade - Angústia - aparece no interior da imagem, como uma legenda interna ou tatuagem que marca essa superfície sensível (figs. 30, 31 e 32), e que atrai o olhar do observador, todas as outras imagens são não-lugares no sentido de não-importa-que-lugares, característica do que André Rouillé identifica como a produção de uma 'arte-fotografia' dos anos noventa e dois mil:

A arte-fotografia tem origem numa vasta abertura temática, numa imensa renovação de visibilidades. No território social, por exemplo, os lugares de ontem abrem espaço aos "não-lugares", e as paisagens a isso que poderíamos chamar de “infrapaisagens”. Aos espaços identitários, relacionais, carregados de história e de 
humanidade, aos lugares antropológicos aos quais sucedem as imagens das zonas de lazer, de atividades comerciais, de trânsito, de errância ou de exclusão. Além disso, o ordinário é geralmente figurado sem efeitos formais, de maneira tão neutra e transparente quanto possível, sem jogos de luzes brilhantes ou refinadas, sem composições aparelhadas, sem pontos de vista insólitos. Recusar os temas e as formas extraordinárias, figurar ordinariamente o ordinário [...]. ${ }^{477}$

É por essa falta de sentido preciso das imagens, pela impressão que o que se mostra é tão pouco e banal, que a atenção do leitor/espectador recorre às legendas, todas concentradas numa única folha depois da última fotografia. É ao vê-las todas juntas em bloco, condensadas, repetindo exatamente aquilo que se vê em cada uma das imagens e acrescido do qualificativo 'de Angústia', que surge uma lista-poema:

\author{
Entrada de Angústia \\ Entrada de Angústia \\ Casa de Angústia. Mercearia de Angústia \\ Casa de Angústia \\ Escola de Angústia. Monumento aos mortos de Angústia \\ Discoteca de Angústia \\ Campo de esportes de Angústia \\ Prefeitura de Angústia. Igreja de Angústia \\ Bar de Angústia \\ Restaurante de Angústia \\ Cemitério de Angústia. Túmulo de Angústia \\ Angústia à noite \\ Saída de Angústia ${ }^{478}$
}

Como escreve Thomas Clerc sobre Angoisse: "a fotografia não vem dar uma significação suplementar a isso que a linguagem já carrega com uma força inigualável. É nisso que a arte de Édouard Levé é fundamentalmente literária já que ele faz aqui um uso nãofotográfico da fotografia" 479 .

${ }^{477}$ L'art-photographie procède donc à une vaste ouverture thématique, à un immense renouvellement des visibilités. Dans le territoire social, par exemple, les lieux d'hier font place aux "non-lieux”, et les paysages à ce que l'on pourrait nommer des "infra-paysages”. Aux espaces identitaires, relationnels, chargés d'histoire et d'humanité, aux lieux anthropologiques donc succèdent dans les images des zones de loisirs, d'activités commerciales, de transit, d'errance ou d'exclusion.

En outre, l'ordinaire est souvent figuré sans effets formels, de façon aussi neutre et transparente que possible, sans éclairages éclatants ou raffinés, sans compositions charpentées, sans angles de vue insolites. Refuser les thèmes et les formes extraordinaires, figurer ordinairement l'ordinaire [...]. ROUILLÉ. L'ordinaire, le dérisoire. In: . La photographie, 2006, pp. 560-561.

${ }^{478}$ Entrée d'Angoisse / Entrée d'Angoisse / Maison d'Angoisse. Épicerie d'Angoisse / Maison d'Angoisse / École d'Angoisse. Monument aux morts d'Angoisse / Discothèque d'Angoisse / Terrain de sports d'Angoisse / Mairie d'Angoisse. Église d'Angoisse / Bar d'Angoisse / Restaurant d'Angoisse / Cimetière d'Angoisse. Tombe d'Angoisse / Angoisse de nuit / Sortie d'Angoisse. LEVÉ. Reconstitutions. Angoisse, 2008a, s/ nº p.

${ }^{479}[. .$.$] la photographie ne vient pas donner une signification supplémentaire à ce que le langage charrie déjà$ avec une force nonpareille. C'est en cela que l'art d'Édouard Levé est fondamentalement littéraire puisqu'il 


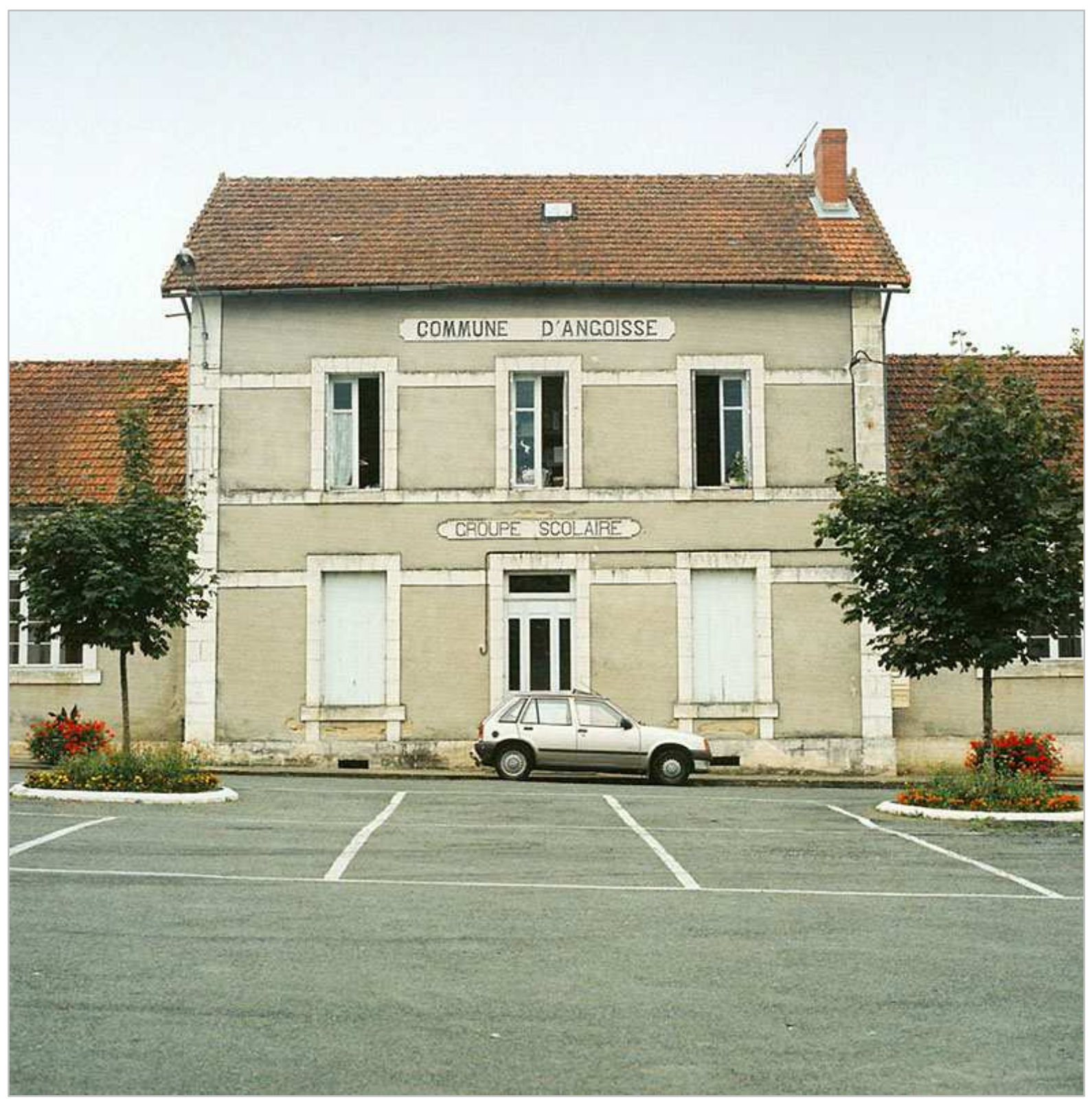

Figura 31 - Édouard Levé. École d'Angoisse [Escola de Angústia], fotografia.

É a partir do reconhecimento desse desvio do uso da legenda - que ganha agora valor literário - que o leitor pode voltar às fotografias para ver o que não via antes e experimentar, por meio de uma contrainte de leitura, a composição de uma lista com tudo o que designaria cada uma das coisas mostradas nas fotografias dessa série. Como exemplo, volto à fotografia que abre o livro de Levé: Entrée d'Angoisse (fig. 30), e 'leio':

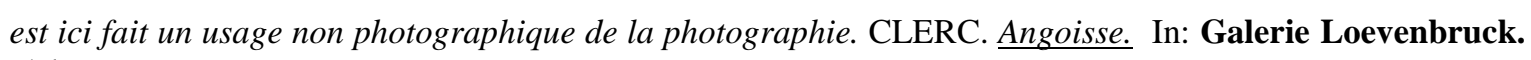
s/ data. 


\author{
Cerca de Angústia \\ Arame farpado de Angústia \\ Estrada de Angústia \\ Flores de Angústia \\ Céu de Angústia \\ Janelas fechadas de Angústia etc.
}

A angústia que domina esse trabalho de Levé diz respeito ao cotidiano e às coisas por aquilo que há de difuso e indeterminado nesse sentimento. Em Que é metafísica?, Heidegger explica que, contrariamente ao que ocorre com o medo - que é sempre 'ter medo de um objeto determinado' -, a angústia é sempre 'estar angustiado por' alguma coisa que não se sabe o que é. Ele também explica que, no caso da angústia, essa indeterminação não é simples falta de determinação mas a pura impossibilidade de determinação. Deparando-se com ela, só nos resta dizer: 'sentimo-nos estranhos'. Tudo isso é revelador do 'nada' e não permite qualquer limite, qualquer fronteira, qualquer conclusão. Para Heidegger ${ }^{480}$ : "a angústia manifesta o nada", como também: "a angústia nos corta a palavra", e "o fato de nós procurarmos muitas vezes, na estranheza da angústia, romper o vazio silêncio com palavras sem nexo é apenas o testemunho da presença do nada". Ainda que não exista um 'nada' objeto, é através da angústia que ele se torna manifesto. Está aí o silêncio que a simples menção dessa palavra evoca e que as imagens de Levé repercutem tão intensamente.

Nessa obra de Levé, o que contribui para intensificar os sentidos da angústia apontados por Heidegger, é o fato dessa obra, da mesma forma que Tentative d'épuisement d'un lieu parisien, também ser reveladora de um não-lugar (ainda que por indícios diversos). Como escreve Augé ${ }^{481}$, o que caracteriza o não-lugar é, entre outras coisas, ele ser um espaço de passagem que, em contraposição ao lugar antropológico - criador de enraizamentos e pertencimentos -, cria 'tensão solitária'. As fotografias de Levé apresentadas aqui dão destaque à estrada, ao asfalto, ao carro e a uma arquitetura cenográfica, sugerindo um campo de movimentação impessoal. Mas a característica mais importante que amplifica essa condição está no que Marc Augé reconhece como um sistema de comunicação particular com vocabulário, tipografias, dimensões, cores, símbolos, formas, particulares: é o sistema de sinalização de todo sistema viário e que também está presente em edifícios, supermercados, ou qualquer espaço de circulação de pessoas, um sistema que visa informar e/ou orientar e/ou determinar e/ou constrangir o(s) indivíduo(s), sendo portanto um manual de instruções do

\footnotetext{
${ }^{480}$ HEIDEGGER. Que é metafísica?, 1969, p. 32.

${ }^{481}$ AUGÉ. Não-Lugares, 2001, p. 87.
} 
espaço coletivo. Nas fotos de Levé isso surge com as placas de estrada: é por elas que o observador é apresentado à cidade (fig. 30), identifica o edifício público (fig. 31) e se despede desse espaço para continuar sua viagem (fig. 32). Como explica Marc Augé ${ }^{482}$ :

Todas as interpelações que emanam de nossas estradas, centros comerciais ou vanguardas do sistema na esquina de nossas ruas visam simultânea e indiferentemente a cada um de nós [...], qualquer um de nós: elas fabricam o "homem médio", definido como usuário do sistema rodoviário, comercial ou bancário. [...].

Sozinho, mas semelhante aos outros, o usuário do não-lugar está com este (ou com os poderes que o governam) em relação contratual.

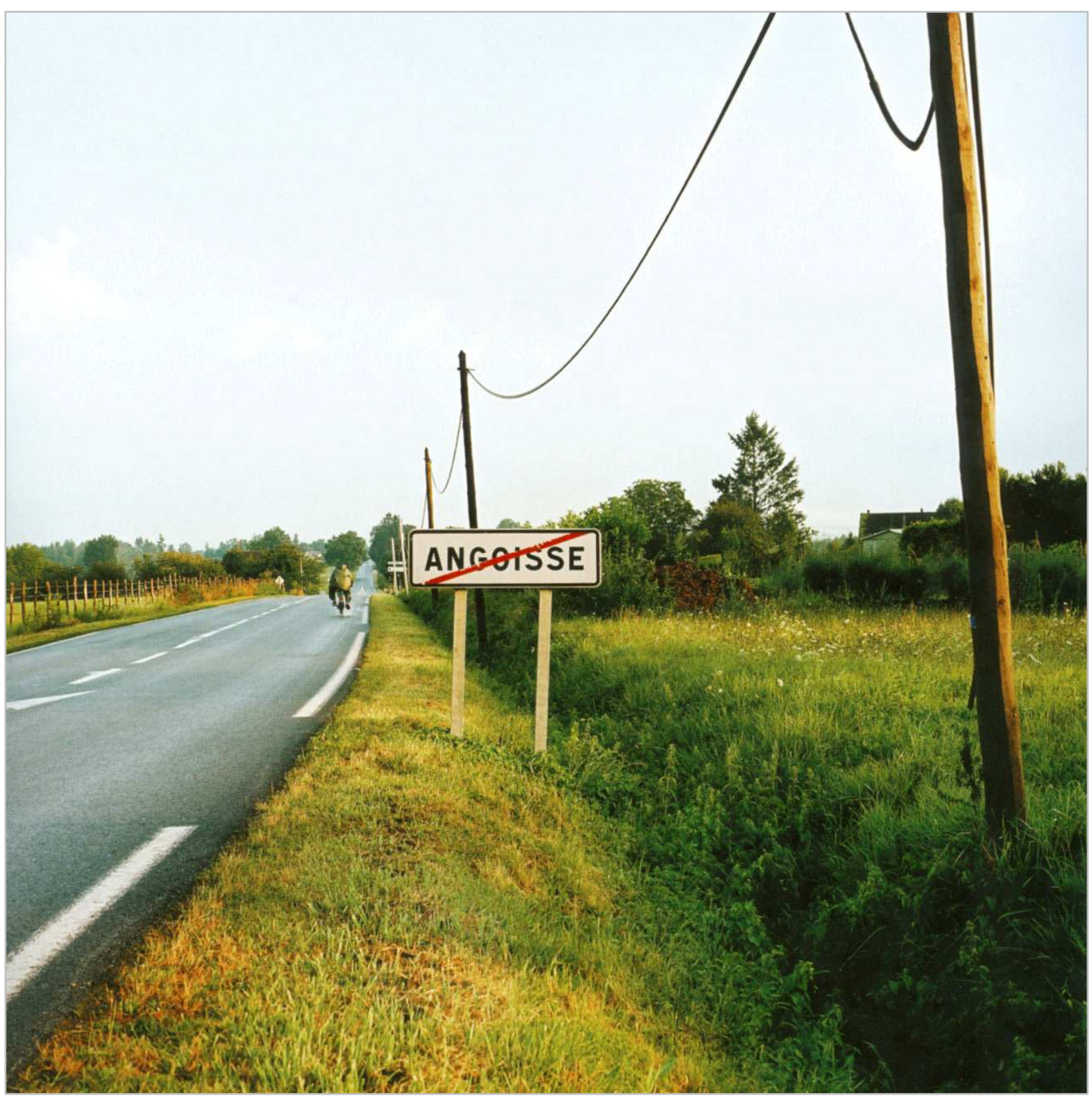

Figura 32 - Édouard Levé. Sortie d'Angoisse [Saída de Angústia], fotografia.

${ }^{482}$ AUGÉ. Não-Lugares, 2001, pp. 92-93. 
O estranhamento provocado pela obra de Levé é também um paradoxo: como é possível indicar a localização de Angústia se, justo a 'angústia' é do campo do indeterminado, do impreciso e do ilocalizável? Daí o silêncio das imagens também ser amplificado por aquilo que também indica Augé ${ }^{483}$ : "O espaço do não-lugar não cria nem identidade singular nem relação, mas sim solidão e similitude."

\subsection{O que não é dado ver}

Todo o trabalho da escrita se faz sempre com relação a uma coisa que já se foi, que pode se fixar por um instante na escrita, como um traço, mas que desapareceu. ${ }^{484}$

Georges Perec

Em 1981, quando Perec foi convidado a participar do Colóquio Espace \& Représentation [Espaço e Representação], ele resolveu abordar alguns questionamentos que diziam respeito ao exercício da descrição: “'o que descrevemos quando descrevemos ?’, ‘o que vemos quando olhamos?', 'Porque descrevemos?', 'Como vemos?', 'Como nos deslocamos no espaço?", ${ }^{485}$ Para tentar responder a algumas dessas perguntas, o escritor abordou sua experiência com um exercício de descrição encomendado meses antes por um professor da École Nationale Supérieure d'Architecture de Paris (U.P.A. 6), Gérard Brassel. Para essa encomenda, a tarefa de Perec seria a de descrever uma pequena área na cidade de Paris onde Brassel desenvolvia um projeto de arquitetura. A justificativa para esse pedido era a experiência e o interesse do escritor em abordar em sua obra diferentes lugares na cidade de Paris (sem dúvida, estava-se fazendo referência aqui ao projeto de Lieux, apresentado em Espèces d'espaces).

Foi a partir de duas idas ao local indicado por Brassel e da dificuldade em executar o que lhe havia sido pedido, que o escritor passou a explicar/justificar suas dificuldades em

\footnotetext{
483 AUGÉ. Não-Lugares, 2001, p. 95.

${ }^{484}$ Tout le travail d'écriture se fait toujours par rapport à une chose qui n'est plus, qui peut se figer un instant dans l'écriture, comme une trace, mais qui a disparu. VENAILLE. Le travail de la mémoire. (1979). In: PEREC. Je suis né, 2006, p. 91.

485 “Qu'est-ce qu'on décrit quand on décrit?”, “qu'est-ce qu'on voit quand on regarde?”, “Pourquoi décriton ?", “Comment voit-on ?”, "Comment se déplace-t-on dans un espace ?”. PEREC. À propos de la description. (1981). In: RENIER. Espace \& Représentation, 1989, p. 325.
} 
cumprir com a tarefa: o pedido de Brassel era vago e Perec não tinha qualquer envolvimento pessoal com aquela área da cidade. Daí, concluiu Perec: "a primeira coisa que se pode fazer, é vir experimentar sua própria cegueira, quer dizer, nossa incapacidade de ver. Ver o quê? Porque no início não há nada além da opacidade, nomes que não evocam nada, além disso, eu não sei." 486

Perec explica então que todos os lugares com os quais ele havia trabalhado em seus textos tinham sempre uma ligação com suas experiências e sua vida pessoal: "lugares onde tudo me dá sinais, lugares que funcionavam como códigos." ${ }^{487}$ Já, o lugar designado por Brassel não the dizia respeito em nenhum aspecto, a não ser pelo fato de estar na mesma cidade onde ele morava. Por tudo isso, Perec acreditava que a única forma possível de estabelecer um contato com aquele 'lugar sem sentido' seria buscar ali elementos que lhe permitissem estabelecer relações com algo do seu interesse.

Perec afirmava então que não funcionava por ideias, mas por excitações e inibições outros nomes para 'impulsos' (que são de ordem pessoal) e 'restrições' (suas contraintes). Sem isso, Perec reconhecia que suas iniciativas resultavam em material protocolar, sem conflitos e sem limites a serem rompidos. Para que ele conseguisse descrever o espaço seria necessário que, de alguma forma, esse espaço lhe fosse significativo ou então que lhe permitisse encontrar ali códigos de sentido, do contrário, não seria possível ver nada, estabelecer relações, propor questionamentos. Perec havia escrito em Espèces d'espaces: "O espaço é uma dúvida: é necessário sempre marcá-lo, designá-lo; ele nunca está comigo, ele nunca me é dado, é necessário que eu o conquiste" ${ }^{488}$ (Ee, p. 122). Para Perec, esses códigos que ele precisava descobrir/marcar/inventar é que seriam os responsáveis pelo interesse e pela orientação das ações no exercício da descrição:

São coisas que eu aprendi a conhecer que se tornaram codificadas, a partir do
momento em que elas se prenderam a alguma coisa que me era, digamos, próxima,
que se prenderam a uma história, alguma coisa que tinha um sentido para mim. O
problema do espaço, o primeiro problema do espaço, é quando nos encontramos no
espaço [...], há certo número de coisas que sabemos, que esperamos ver, ou que
reconhecemos, ou que inventamos, porque nós as inventamos a partir de alguma

${ }^{486}$ La première chose que l'on peut faire, c'est venir y éprouver sa propre cécité, c'est-à-dire notre incapacité à voir. Voir quoi? Car au départ il n'y a qu'opacité, des noms qui n'évoquent rien, ensuite je ne sais pas. PEREC. À propos de la description. (1981). In: RENIER. Espace \& Représentation, 1989, p. 327.

487 Des lieux où tout me fait des signes, des lieux qui fonctionnaient comme code. Ibidem.

${ }^{488}$ L'espace est un doute: il me faut sans cesse le marquer, le désigner; il n'est jamais à moi, il ne m'est jamais donné, il faut que j'en fasse la conquête. 
coisa que nos foi dada. Quando nada nos é dado, um bloco de casas se parece com não importa qual bloco de casas. ${ }^{489}$

O mais importante nessas afirmações de Perec é saber da importância do vivido para a sua produção, era isso que, de alguma forma, alimentava o que ele escrevia, não importando o tema, o procedimento, ou mesmo a forma que isso resultaria. Era na maioria das vezes como algo subliminar - como o fogo que esquenta a panela.

Reli Tentative d'épuisement d'un lieu parisien algumas vezes e raramente consegui chegar ao fim numa leitura contínua, tranquila. A porta de entrada (ou fresta) foi reconhecer ali um ensaio fotográfico e concentrar minha atenção nas seções, nas páginas, nos fragmentos de texto, até conseguir abstrair o que é texto e me ater ao que é tipográfico - a matéria do texto. Assim pude descobrir os parênteses: limite gráfico do espaço do comentário paralelo que serve para o autor falar 'tudo o que lhe vem à cabeça', em oposição ao texto central que trata de 'tudo o que lhe vem aos olhos'. É nesse lugar esquivo que se pode reconhecer a presença de Sei Shônagon: entre os parênteses, na penumbra, mesmo lugar onde o autor fala sozinho, pensa em voz alta e trata do que é subalterno ao texto central.

É num desses espaços que leio (ouço?): "Curiosidade frustrada (o que eu vim procurar, a lembrança que paira neste café...)" ${ }^{490}$ (Telp, p. 38). As reticências indicam que o autor poderia falar mais sobre o assunto, mas ainda assim resolve se calar. Agora, além dos parênteses, também me preocupo com as reticências...

Volto à Espèces d'espaces para reler o que entendo ser o 'manual de instruções' de Tentative de description d'un lieu parisien, e no item que vem logo após Travaux pratiques, Perec escreveu Brouillon de lettre [Rascunho de carta] e que acaba justamente com a marcação '(...)' e não com 'ponto final':

Eu penso muito em você

às vezes eu entro num café, me sento perto da porta, peço um café

ponho sobre a mesinha de mármore falso meu pacote de cigarros, uma caixa de fósforos, um bloco de papel, minha hidrográfica

${ }^{489}$ Ce sont des choses que j’ai apprises à connaître qui sont devenues codées, à partir du moment où elles se rattachaient à quelque chose qui m'était, disons, proche, qui se rattachaient à une histoire, quelque chose qui avait un sens pour moi. Le problème de l'espace, le premier problème de l'espace, c'est que quand on se trouve dans un espace [...], il y a un certain nombre de choses que l'on sait, que l'on s'attend à voir, ou que l'on reconnaît, ou que l'on invente, parce qu'on les invente à partir de quelque chose qui vous est donné. Lorsque rien ne vous est donné, un pâté de maisons ressemble à n'importe quel pâté de maisons. PEREC. $\underline{A}$ propos de la description. In: RENIER. Espace \& Représentation, 1989, p. 331.

${ }^{490}$ Curiosité inassouvie (ce que je suis venu chercher, le souvenir qui flotte dans ce café...). 
mexo por um bom tempo a colherzinha na xícara de café (contudo, não açucaro meu café, eu o bebo deixando o açúcar derreter na minha boca, como as pessoas do norte, como os russos e os poloneses quando eles bebem o chá)

finjo estar preocupado, pensante, como se tivesse uma decisão a tomar

No alto e à direita da folha de papel, escrevo a data, às vezes o lugar, às vezes a hora, finjo escrever uma carta

escrevo lentamente, muito lentamente, o mais lentamente possível, eu traço, eu desenho cada letra, cada acento, eu confiro os sinais de pontuação

[...] o dono cochila atrás do caixa, a servente limpa a máquina de café

Eu penso em você

Você anda por sua rua, é inverno, você levanta a gola do seu casado de lobo, você está sorridente e distante

(...) ${ }^{491}($ Ee, pp. 74-75)

O lugar significativo para Perec em Tentative d'épuisement d'un lieu parisien não é a place Saint-Sulpice, mas o interior do café, ou melhor, uma de suas mesas a partir de onde ele se sente apto/disposto/distante para observar 'o que acontece quando não acontece nada'. Se o indizível da infância de Perec está ligado à guerra e ao campo de concentração (um não-lugar fantasmático que se revelaria apenas com a publicação de $W$ ), agora, na fase adulta, o espaço do indizível é a mesa de um bar e diz respeito a uma paixão.

${ }^{491}$ Je pense à toi, souvent / parfois je rentre dans un café, je m'assieds près de la porte, / je commande un café / je dispose sur le guéridon de faux marbre mon paquet de cigarettes, une boîte d'allumettes, un bloc de papier, mon stylo-feutre / je remue longtemps la petite cuiller dans la tasse de café (pourtant je ne sucre pas mon café, je le bois en laissant fondre le sucre dans ma bouche, comme les gens du Nord, comme les Russes et les Polonais quand ils boivent du thé) / Je fais semblant d'être préoccupé, de réfléchir, comme si j'avais une décision à prendre / En haut et à droite de la feuille de papier, j'inscris la date, parfois le lieu, parfois l'heure, je fais semblant d'écrire une lettre / j'écris lentement, très lentement, le plus lentement possible, je trace, je dessine chaque lettre, chaque accent, je vérifie les signes de ponctuation / [...] / le patron somnole derrière sa caisse, la serveuse nettoie la machine à café / je pense à toi / tu marches dans ta rue, c'est l'hiver, tu as relevé le col de ton manteau de loup, tu es souriante et lointaine / (...). 


\section{(In)Conclusão...}

Em se tratando da obra perequiana, o pessoal e o coletivo, o intuitivo e o programado, o particular e o banal, a escrita autobiográfica e a ficcional, tudo ali se mistura e Perec, ao se esforçar por expor algum tipo de controle sobre sua produção, explica: "os livros que eu escrevi se prendem a quatro campos diferentes, quatro modos de interrogação que colocam, talvez, no final das contas, a mesma pergunta, mas a colocam segundo perspectivas particulares correspondendo cada vez para mim a outro tipo de trabalho literário." ${ }^{492}$ Esses campos de cultivo nos quais germinam suas perguntas têm como substrato: o mundo, sua história pessoal, a linguagem e a ficção. Esta pesquisa se centrou no primeiro desses campos, mas foi inevitável também não passar pelos outros para explorar o que seria o 'Mundo segundo G.P.'. Um mundo que não é o 'Mundo de G.P.' porque é um mundo comum literário, certo -, mas o mundo de quem tem o pés no chão. Burgelin resume assim as principais características desse mundo de muitas coisas e pouco sentido:

A partir da biblioteca, da lista, da lista telefônica, dos lugares onde o imaginário existe apenas desvinculado de pulsões e emoções, ele recria possibilidades de imaginar e contar. [...] Do mundo, ele recolhe as migalhas e os restos e, geralmente, os serve sem qualquer tempero, tais e quais - nova maneira de compô-los. Na origem das receitas perequianas, há sempre fragmentação e esmigalhamento. ${ }^{493}$

E, aproveitando o que expus da obra de Arman, recorro ao que Umberto Eco ${ }^{494}$ escreveu sobre ela e assim também pensar com o que ocorre na obra de Perec:

Em um texto anterior sobre Arman [...], insisti sobre o aspecto que primeiro se evidencia de sua obra - a acumulação de objetos -, que relacionei a uma tendência permanente na história das artes, a saber a poética da enumeração ou do catálogo.

\footnotetext{
492 [...] les livres que j'ai écrits se rattachent à quatre champs différents, quatre mode d'interrogation qui posent peut-être en fin de compte la même question, mais la posent selon des perspectives particulières correspondant chaque fois pour moi à un autre type de travail littéraire. PEREC. Notes sur ce que je cherche. (1978). In: Penser / Classer, 2003c, pp. 9-10.

${ }^{493}$ À partir de la bibliothèque, de la liste, de l'annuaire, de ces lieux où l'imaginaire n'existe que coupé des pulsions et émotions, il recrée des possibilités d'imaginer et de conter. [...] Du monde, il récolte les miettes et les reliefs et, souvent, les sert sans sauce aucune, tels que - nouvelle façon de les accommoder. À l'origine des recettes perecquiennes, il y a toujours la fragmentation e l'émiettement. BURGELIN. Les Parties de dominos chez. Monsieur Lefèvre, 1996, p. 222.
}

${ }^{494}$ ECO. Sobre Arman. In: Arman. 1998, p. 15. 
A poética do catálogo parece caracterizar o tempo da dúvida quanto à forma e à natureza do mundo, em oposição à poética da forma acabada, típica dos momentos de certeza sobre nossa identidade.

A um 'tempo de dúvidas', como escreve Eco, Perec responde com contraintes e perguntas. Como salientei anteriormente ${ }^{495}$, Perec está do lado das perguntas, e não das respostas e por isso, como reconhece Burgelin: "Perec não se entrega ao tranquilizador e mentiroso "porque", ${ }^{496}$. Antes de perguntar aos seus leitores, o próprio Perec treinava se perguntando:

Qual é a boa pergunta, aquela que me permitirá realmente responder, realmente me responder? Quem sou? O que sou? Onde estou?

Posso medir algum caminho percorrido? Cumpri alguns dos objetivos que tinha fixado para mim, se é que eu, algum dia, me fixei objetivos? Posso dizer que hoje sou o que um dia quis ser? [...]. ${ }^{497}$

Eu sei, grosso modo, como me tornei escritor. Eu não sei precisamente o porquê. Eu tinha mesmo necessidade, para existir, de alinhar palavras e frases? Seria suficiente para mim, para ser, ser o autor de alguns livros?

$\mathrm{Eu}$ esperava, para ser, que os outros me designem, me identifiquem, me reconheçam. Mas porque pela escrita? Por muito tempo quis ser pintor, pelas mesmas razões, suponho, mas me tornei escritor. Por que precisamente a escrita? ${ }^{498}$

Eu reconheço que a obra de Perec continua potente e instigante exatamente pelas perguntas que continua fazendo e pela maneira como instiga e coopta seu leitor, acompanhando exatamente o movimento incessante de uma parcela da arte contemporânea (em se tratando da diversidade da obra perequiana é preciso ter cautela com as generalizações). Para entender como se efetivam esses diálogos, eu localizo basicamente dois campos de interação: primeiro, pelas perguntas propostas pela obra e, segundo, pelo jogo da escrita que reserva sempre um espaço vazio a ser ocupado pelo leitor.

${ }^{495}$ Cf. item 2.6.

${ }^{496}$ [...] Perec ne se livre pas au rassurant et mensonger "parce que". BURGELIN. Les Parties de dominos chez Monsieur Lefèvre, 1996, p. 233.

${ }^{497}$ Quelle est la bonne question, celle qui me permettra de vraiment répondre, de vraiment me répondre? Qui suis-je? Que suis-je? Où en suis-je? / Puis-je mesurer quelque chemin parcouru? Ai-je rempli quelques-uns des buts que je m'étais fixés, si vraiment je me suis un jour fixé des buts? Puis-je dire aujourd'hui que je suis ce que jadis j'ai voulu être? [...]. PEREC. Les gnocchis de l'automne ou Réponse à quelques questions me concernant. (1972). In: Je suis né, 2006, p. 70.

498 Je sais, en gros, comment je suis devenu écrivain. Je ne sais pas précisément pourquoi. Avais-je vraiment besoin, pour exister d'aligner des mots et des phrases? Me suffisait-il, pour être, d'être l'auteur de quelques livres? / J'attendais, pour être, que les autres me désignent, m'identifient, me reconnaissent. Mais pourquoi par l'écriture? J'ai longtemps voulu être peintre, pour les mêmes raisons je suppose, mais je suis devenu écrivain. Pourquoi précisément l'écriture? Ibidem, p. 72. 
No campo da obra perequiana, tão importante quanto as ideias, as perguntas, o texto, o traço, é também relevante levar em conta o vazio das motivações, o silêncio das respostas, a invisibilidade das imagens matrizes e o branco da folha de papel, espaço que recebe o texto, aproxima e distancia palavras, subverte e anima sentidos, ganha relevância. Como Perec escreve em Espèces d'espaces: "Eu escrevo: eu habito minha folha de papel, tomo posse dela e a percorro. Eu suscito brancos, espaços (saltos no sentido: descontinuidades, passagens, transições)" ${ }^{499}$ (EE, p. 19).

Em duas declarações de Perec em 1981 - que exprimem bem uma dificuldade em abordar/esclarecer sem querer facilitar/simplificar -, o escritor trata do que entende como 'marca do indizível'. Na primeira, Perec afirma:

Eu sei que o que é muito importante, é que no meio de $W$ há isso... o sinal da falta, que é a separação de meus pais, a perda... que, curiosamente, eu também reencontro no meio do palíndromo. Efetivamente, todo o tempo, há esse tipo de figura que volta, mas isso é uma coisa que se encontra nos livros mas... eu não sei como dizer... é por isso que eu escrevo. ${ }^{500}$

E, na segunda, Perec volta a citar a mesma 'marca do indizível':

Eu tenho esse sentimento, quando a gente começa a escrever, de encontrar... um tipo de figura, aquela se chama uma espécie de universo de ficção, de palavra, de tomada de palavra, do dicionário e que têm ( sic) um lugar fixo... cada livro sendo ele mesmo interior a essa ficção... A falta, ela está no interior do palíndromo. No meio do palíndromo, há três pontinhos ${ }^{501}$; no meio de "W", há três pontinhos que são o que eu nunca direi, porque outras palavras virão a seguir, tomar seu lugar. ${ }^{502}$

499 J'écris: j'habite ma feuille de papier, je l'investis, je la parcours.

Je suscite des blancs, des espaces (sauts dans le sens: discontinuités, passages, transitions).

${ }^{500}$ Je sais que ce qui est très important, c'est qu'au milieu de $\mathrm{W}$ il y ait ceci... le signe de l'absence, qui est la séparation de mes parents, la perte... que je retrouve aussi curieusement au milieu du palindrome. Effectivement, tout le temps, il y a ce type de figure qui revient, mais ça, c'est une chose qui se trouve dans les livres mais... je ne sais pas comment dire... c'est pour ça que j'écris. POUS. Entretien Georges Perec / Bernard Pous. (1981). In: PEREC. Entretiens et Conférences, 2003b, p. 193.

${ }^{501}$ No meio do grande palíndromo escrito por Perec em 1970 (9691 Edna d’Nilu O. Mú, Acéré. Pseg Roeg) (Cf. item 2.2.) aparecem esses 'três pontinhos' isolados no espaço em branco entre dois parágrafos. Eles desaparecem na versão publicada in: PEREC. Palindrome. In: OULIPO. La littérature potentielle, $2003 \mathrm{a}, \mathrm{p}$. 100; e reaparecem in: PEREC. Palindrome. In:___. La clôture et autres poèmes, 1980, p. 49.

502 J'ai ce sentiment, quand on commence à écrire, de rencontrer... une sorte de figure, celle-là s'appelle une espèce d'univers de fiction, de parole, de prise de parole, du dictionnaire et qui ont une place fixe... chaque livre étant lui-même intérieur à cette fiction... Le manque, il est à l'intérieur du palindrome. Au milieu du palindrome, il y a trois petits points; au milieu de "W", il y a trois petits points qui sont ce que jamais je ne dirai, parce que d'autres paroles viendront ensuite, le remplacer. PEREC. À propos de la description. (1981). In: RENIER. Espace \& Représentation, 1989, p. 342. 
Se na obra bipartida $W$, a página em branco com os sinais de reticências entre parênteses (fig. 33) repercute a frase que inicia a parte autobiográfica do livro: "Eu não tenho lembranças de infância" ${ }^{503}$ (W, p. 17), no grande palíndromo - obra igualmente bipartida, mas agora pelo sentido da leitura - repercute, segundo alguns autores, a divisão de Perec entre dois estados de ser: o de ser francês e o de ser judeu. Isso porque a leitura do palíndromo deve ser possível tanto da esquerda para a direita como o contrário, da direita para a esquerda - exatamente os mesmos sentidos da escrita ocidental e da escrita iídiche. Por mais formal que pareça esse tipo de exercício da escrita, não se pode esquecer que na obra perequiana é bem provável que sempre se encontre alguma motivação pessoal do autor, como ele mesmo afirma: "quase nenhum dos meus livros escapa completamente de certa marcação autobiográfica." 504 Para que não se pense

Figura 33 - Georges PEREC. W ou le souvenir d'enfance, 2003d, p. 89.

\footnotetext{
${ }^{503}$ Je n'ai pas de souvenirs d'enfance.

${ }^{504}[. .$.$] presque aucun de mes livres n'échappe tout à fait à un certain marquage autobiographique [...].$ PEREC. Notes sur ce que je cherche. (1978). In: . Penser / Classer, 2003c, p. 10.
} 
que essa marca sinaliza apenas um trauma de infância do escritor, é bom lembrar que o Brouillon de lettre apresentado no final do item anterior também termina com as reticências no interior de parênteses. Nesse contexto, o mesmo traço parece indicar outro tipo de incômodo que, mesmo não sendo possível esclarecer exatamente o que é, é ainda alguma coisa que não se pode e/ou não se sabe e/ou não se quer dizer.

No que se refere à construção da obra perequiana, não existem pressões depressivas ou paralisantes e tanto o vazio, o silêncio, a invisibilidade quanto o branco e o indizível são componentes altamente mobilizadores - basta pensar na amplitude de interesses de sua obra e na pluralidade de autores e artistas que dialogam e/ou são simpáticos às suas iniciativas.

Por tudo isso, como é que todas essas formas negativas de exposição/comunicação podem engendrar discursividade, estimular a fala de outros autores e permitir a Perec a construção/instituição de um mundo: ‘o Mundo, segundo G. P.'? E, nesse contexto, qual a relevância de uma marca, de um sinal de pontuação?

As insignificâncias que Perec reconhecia no mundo, ele as repassaria à sua escrita por meio de novas insignificâncias e fazendo uso de procedimentos que revelavam algum tipo de estranhamento - exemplo disso é Tentative d'épuisement d'un lieu parisien. É o que também ocorre em la page [a página] logo no início de Espèces d'espaces (fig. 34), quando ele contrapõe a mesma frase 'J'écris' [eu escrevo] com e sem o acompanhamento de reticências sinal gráfico que identifica o que o autor escreve: 'J'écris...' [Eu escrevo...].

\section{J'écris...}

\section{J'écris : j'écris... J'écris : «j'écris... " J'écris que j'écris... etc.}

Figura 34 - Georges Perec. la page [a página] (detalhe). (Ee, p. 17).

Para entender o que significa a recorrência das reticências na escrita perequiana, é necessário esclarecer os significados distintos desse sinal de pontuação de acordo com sua posição no enunciado. 
Segundo Véronique Dahlet ${ }^{505}$, entre os sinais produtores de metadiscurso, as reticências se destacam por "suspender o dizer e instalar o silêncio". Entre as funções básicas das reticências, Dahlet ${ }^{506}$ explica que elas tanto podem marcar diferentes graus de suspensão do pensamento, como a suspensão do discurso em função de hesitações, surpresa, dúvida etc. Como características que as distinguem de outros sinais de pontuação, Dahlet ${ }^{507}$ destaca, primeiro, a mudança de significado das reticências em função do texto ser um diálogo ou um monólogo, segundo, a mudança de sentido do sinal gráfico dependendo da sua posição no discurso e, terceiro e mais importante, o fato das reticências serem 'ostensivamente interativas' - o que requer a participação efetiva do leitor para a completude do seu sentido.

No contexto monologal, o sentido das reticências muda de acordo com sua posição no enunciado:

1) no início do enunciado, as reticências fazem referência a um antitexto, verdadeiro ou não, e configuram o chamado in media res [no meio das coisas], que é quando o início da narrativa se dá com a história já em andamento;

2) no meio do enunciado, o uso das reticências visa retardar o desenvolvimento da narrativa, ou ainda, criar uma expectativa sobre o que está para acontecer; e

3) no final do enunciado, as reticências são o sinônimo de 'etc.' e indicam que, mesmo havendo algo ainda a ser dito, isso não se dará, indicando então um dizer in absentia. Nesse lugar, indica Dahlet ${ }^{508}$, “as /.../ são, por excelência, sinal de cooperação".

Quanto à participação do leitor na completude do sentido desse tipo de sinal de pontuação, Dahlet $^{509}$ explica que, para que o silêncio das reticências se instale e funcione como o esperado, é indispensável "que o interlocutor esteja de acordo com as premissas do disposto: se, por acaso, este se recusa ao trabalho interpretativo, as /.../ perdem sua eficácia, seu poder de fazer transcender a significação além do disposto”. O papel das reticências é (p)reservar um espaço de silêncio deixado ali pelo locutor, que tanto pode servir para que o interlocutor tome a palavra e desenvolva ali seu texto, seu conhecimento, sua lembrança, sua

\footnotetext{
505 DAHLET. $O$ dizer em silêncio: as reticências. In: I Seminário Nacional de Linguística e Língua Portuguesa, 1995, p. 20.

${ }^{506}$ DAHLET. As (man)obras da pontuação, 2006, p. 204.

${ }^{507}$ Ibidem, pp. 204-211.

${ }^{508}$ Ibidem, p. 208.

${ }^{509}$ DAHLET. O dizer em silêncio: as reticências. Op. cit., p. 26.
} 
opinião, seu desejo, como para que o interlocutor se dê conta do silêncio daquele que fala e se conscientize dessa impossibilidade de expressão (como ocorre, por exemplo, em $W$ ). Ainda sobre essa nova função do interlocutor, Dahlet ${ }^{510}$ acrescenta:

[...] é preciso que o interlocutor abandone de certa forma o lugar que o constitui para ocupar o espaço que foi deixado vago, para fazer falar o silêncio. Quanto a conhecer o grau desta atenuação (ou seja, até onde o interlocutor se engajará para interpretar o não-dito), e a qualidade dessa atenuação (ou seja, em que medida o meu interlocutor vai em seu trabalho de interpretação, restabelecer o conteúdo ausente no mesmo sentido que eu) é difícil de avaliar.

$[\ldots]$

Se a comunicação baseia-se idealmente no bom entendimento (nos dois sentidos de boa compreensão e de boa cooperação) e a completude; se apesar de tudo, ela se caracteriza por malogros, retomadas e reformulações, ela se compõe também por brechas de silêncio que não são paradas, mas verdadeiras fábricas do sentido, que asseguram a ligação entre o dizer anterior e o dizer vindouro.

Pela condição de mobilidade desse símbolo gráfico, pela incompletude do discurso que ele indica e por seu estímulo à ação/reflexão do leitor, a ideia das reticências é potencialmente instauradora de duas forças: a que implica ver o mundo de viés e a que promove a discursividade - uma leitura produtora/desdobradora/amplificadora de sentido por parte do leitor $^{511}$.

Bernard Magné, em Ironies péréquiennes ${ }^{512}$ [Ironias perequianas], escreve que "le regard 'en biais'” [o olhar de viés] fundamenta a maneira como Perec percebe o mundo e a si mesmo e para isso cita duas afirmações do escritor:

Certa arte da leitura - e não apenas a leitura de um texto, mas disso que chamamos a leitura de um quadro, ou a leitura de uma cidade - poderia consistir em ler de viés, a empreender sobre o texto um olhar oblíquo $\left[\ldots . .{ }^{513}\right.$

${ }^{510}$ DAHLET. $O$ dizer em silêncio: as reticências. In: I Seminário Nacional de Linguística e Língua Portuguesa, 1995, p. 26.

${ }^{511}$ Para Foucault, alguns autores alcançariam uma posição transdiscursiva que os transformaria em 'fundadores de discursividade' visto eles não serem apenas os autores de suas obras, mas produtores de possibilidades e regras que instigariam/configurariam a formação de novos textos. É essa potencialidade que reconheço na obra de Perec, principalmente a que trata do espaço, do cotidiano e do infraordinário, capaz de propor novos discursos nos quais cabem certas diferenças e atualizações que, além de ocupar os espaços deixados em aberto pelo autor, também beneficiam e amplificam a compreensão das ideias do texto original. Cf. FOUCAULT. O que é um Autor? (1969). In: Estética: literatura e pintura, música e cinema, 2006, p. 280.

${ }^{512}$ MAGNÉ. Ironies Péréquiennes. In: Colloque Hégémonie de l'ironie ?, (2007), 2008.

${ }^{513}$ Un certain art de la lecture - et pas seulement de la lecture d'un texte, mais de ce que l'on appelle la lecture d'un tableau, ou la lecture d'une ville - pourrait consister à lire de côté, à porter sur le texte un regard oblique [...]. PEREC. Lire: esquisse socio-physiologique. (1976). In: Penser / Classer, 2003c, p. 113. 
Se eu me olho, também é necessário que, com relação a mim, eu também dê um passo ao lado, da mesma maneira que quando olho um objeto ou um acontecimento. Para descrevê-lo, agarrá-lo, é necessário que eu o olhe um pouco de lado. ${ }^{514}$

Antes de ser uma maneira de olhar, lembra Magné, a ironia é uma figura retórica pela qual se diz o contrário do que se quer dar a entender, provocando um exercício de ambiguidades que pode servir, ou não, aos propósitos do autor. Isso tem relação com o sinal das reticências porque, servindo à 'noção de distanciamento', a ironia afasta o autor do enunciado e isso gera um risco: o de como se dará a sua recepção (e a própria Dahlet também menciona, no caso das reticências, o quanto é difícil prever/garantir/controlar esse tipo de interação). Magné cita então o que escreveu Jankélévitch sobre a ironia: "a ironia é uma chamada que deve ser ouvida; uma chamada que nos diz: complete você mesmo, corrija você mesmo, julgue você mesmo!" 515 Magné lembra também que, ou a ironia é identificada e ouvida com clareza pelo leitor, ou ela não terá o efeito desejado, servindo apenas para promover mal-entendidos de todo tipo. Embora Perec afirme que: "escrever é um jogo que se joga a dois, entre o escritor e leitor - sem que eles nunca se encontrem" ${ }^{516}$, é preciso entender a discrepância do estatuto desses dois participantes já que, como lembra Magné: nesse tipo de jogo, o escritor guarda consigo muitos trunfos. Para que o jogo proposto pelo escritor se desdobre através do leitor e não se dilua nem se desvaneça é necessário seguir uma indicação que o próprio Perec faz aos leitores por intermédio de Paul Klee no preâmbulo de La Vie mode d'emploi: “O olho segue os caminhos que lhe foram traçados na obra" ${ }^{517}$. Isso faz pensar que, mesmo polissêmica e de interesses múltiplos, também na obra perequiana existe um limite para o exercício do leitor interessado.

Se as reticências tomam um lugar real na obra perequiana para designar o silêncio do que é indizível e participar na configuração de um texto que se abre a várias possibilidades de leitura, também no âmbito desta pesquisa identifico esse sinal gráfico como aquilo que aproxima a obra desse escritor do campo das produções e dos interesses da Arte

\footnotetext{
${ }^{514}$ Si je me regarde, il faut aussi que par rapport à moi je fasse un pas de côté de la même manière que lorsque je regarde un objet ou un événement. Pour le décrire, le saisir, il faut que je le regarde un peu de côté. PEREC. En dialogue avec l'époque. (1979). In: Entretiens et Conférences, 2003b, p. 64.

${ }^{515}$ [...] l'ironie est un appel qu'il faut entendre; un appel qui nous dit: complétez vous-même, rectifiez vousmême, jugez par vous-même! JANKÉLÉVITCH, Vladimir. L'ironie. Paris: Flammarion, 1997, p. 64. Apud MAGNÉ. Ironies Péréquiennes. In: Colloque Hégémonie de l'ironie ?, (2007), 2008.

${ }^{516}$ Écrire est un jeu qui se joue à deux, entre l'écrivain et le lecteur - sans qu'ils se rencontrent jamais. PEREC, La vie: règle du jeu. (1978). In: Entretiens et Conférences, 2003a, p. 275.

${ }^{517}$ L'œil suit les chemins qui lui ont été ménagés dans l'œuvre. (Paul Klee, Pädagogisches Skizzenbuch). PEREC. La Vie mode d'emploi, 1994b, p. 15.
} 
Contemporânea. Isso se dá de três maneiras: primeiro, enquanto a própria noção de 'coisa', segundo como um espaço variável que designa formas distintas de agrupamentos e, terceiro, como promotora de discursividade(s).

\section{As reticências como designação das coisas.}

Como foi visto no início da tese, a palavra 'coisa', embora designe o concreto, é totalmente imprecisa e imperfeita quanto àquilo que identifica. A 'coisa pura', que é simples indicação do 'aqui tem coisa' poderia ser representada pela anotação: ‘(...)', e identificar cada uma das obras tratadas na tese. O sentido dessa representação se daria menos por aquilo que nessas obras é 'indizível' (como ocorre com $W$ ), e mais por aquilo que ali pode ser continuamente redefinido.

A incerteza que a percepção inicial da 'coisa' instaura pode ser levada para os três universos tratados pela pesquisa: o do objeto, o da lembrança e o do lugar.

Se penso as coisas como desvios do ser-objeto, que subtraem ou adicionam valores ao objeto, gerando ambiguidades e dúvidas quanto ao seu estatuto, posso localiar as reticências em duas posições opostas que dão a entender discursos distintos sobre o objeto: a coisa enquanto '... objeto', e a coisa enquanto 'objeto...' .

Se a anotação ‘...objeto' serve para pensar o que encontramos em Malheur aux barbus de Arman - objetos mais próximos da materialidade e de uma história que os antecede e justificaria o estado em que se encontram -, a anotação 'objeto...' diz respeito ao que Perec nos apresenta em Les choses, onde os objetos ganham camadas de significação mitológica estranhas ao estatuto do objeto em si.

O mesmo pode ser pensado para as lembranças feito coisas de Brainard e Perec, entendidas agora como '...lembranças' e 'lembranças...'. Se no livro de Brainard as lembranças chegam fragmentárias e incompletas, dependentes do universo de sentidos da infância e juventude do autor (suas '...lembranças'), as lembranças de Perec configuram uma memória coletiva que marca uma a cultura de determinado grupo de indivíduos em uma determinada época e são promotoras de significados particulares: as 'lembranças...' .

Agora, em Tentative d'épuisement d'un lieu parisien e Angoisse, são os não-lugares que se apresentam como 'coisas': se no texto de Perec, o repetitivo, o irrisório e o passageiro são elementos ambíguos e insuficientes para justificar e configurar o espaço descrito como um 'lugar', servindo apenas para identificar um '...lugar', ou seja, um evento in media res (citado 
anteriormente), em Angoisse, todos os sentidos que advém das fotografias de Levé se multiplicam e se afastam daquilo que designa cada uma das fotos para dar a ver outra coisa, ou seja: um 'lugar...'.

\section{As reticências como exercício de agrupamento das coisas.}

Aqui, as mudanças de sentido instaurado pelas reticências em função da sua posição no texto, também permite pensá-las enquanto indicadoras da maneira como se dão os três tipos de agrupamento tratados pela tese: a acumulação, a coleção e o arquivo.

Como forma primitiva de agrupamento, a acumulação se dá pela repetição e pelo acréscimo puro e simples de matéria. Desconsiderando a autonomia, a funcionalidade e qualquer experiência particular com os elementos acumulados, o resultado final configura sempre um todo indistinto onde o que prevalece é sempre uma impressão: a do 'muito'. Se em Les choses sobressai a ideia de que "não podemos parar de ser felizes!" dada pela grande quantidade e variedade de objetos, lugares, nomes, títulos, endereços e marcas que abastecem as imagens de sucesso e felicidade dos personagens, em Malheur aux barbus, o que prevalece é a soma de restos imperfeitos que compõem uma 'fantasia de objeto' e repercute a frase: "mil barbeadores elétricos são mais barbeador elétrico que um único barbeador elétrico". Nas acumulações as reticências têm sentido de 'etc.' e valor de 'sempre mais um pouco'.

Como conjunto estruturado, a coleção é uma organização de objetos que devem deixar de servir a todos para constituir uma abstração que serve ao colecionador. Como o exercício de posse do objeto colecionado é fonte de prazer para o colecionador, este busca dinamizar sua coleção para que ela se mantenha permanentemente incompleta, permitindo a ele prolongar um jogo de busca, aquisição e conquista que agregue sempre novos valores às suas fantasias. Se Je me souviens indica que novos exemplares podem ser agregados desde que façam parte de uma 'memória compartilhada' (ainda que em vias de esquecimento), em I remember, novas lembranças podem ser agregadas desde que venham de outras obras do mesmo autor e preencham os espaços deixados em aberto por ele. Nessas duas obras, é possível reconhecer com clareza o estatuto das lembranças agrupadas e o espaço reservado a novas aquisições no interior do conjunto constituído: as reticências aqui configuram o vazio que, na compreensão do que justifica, delimita e ordena os elementos, sempre pode vir a ser preenchido por aquilo que enriqueça o conjunto.

Por fim, com o arquivo, os esforços contínuos do artista resultam em documentos que vão sendo produzidos/recolhidos/agrupados para compor uma estrutura que ficará à 
disposição do próprio artista ou de um leitor/espectador/pesquisador interessado que poderá (ou não) recontextualizá-los/retrabalhá-los, injetando ali novos significados. Todo arquivo é um canteiro de possibilidades. Se Lieux, de Perec, é um 'projeto de arquivo' de uma única obra, Euvres, de Levé, é o arquivo completo de dezenas de obras. Se Tentative d'épuisement d'un lieu parisien é uma obra que parte de Lieux, Angoisse é um ensaio que parte de Villes [Cidades] - título provável da 'Obra ${ }^{\circ}$ 55' do livro de Levé ${ }^{518}$. Foi se servindo dos seus arquivos que esses dois artistas aproveitaram contraintes, cartas de intenções, antigas referências, conhecimentos técnicos etc., e puderam efetivar e conferir sentido a essas novas iniciativas. O arquivo guarda essa potência: o de registrar/concentrar ações passadas em documentos que esperam por ações/reformulações/reflexões para práticas futuras, ainda que peremaneçam intocados. As reticências acompanham os documentos nesses dois momentos.

\section{As reticências como promotoras de discursividade.}

A presença explícita e implícita do sinal de reticências na obra de Perec e o jogo que sua escrita propõe compõem uma tática tanto sedutora quanto traiçoeira e, talvez por isso, seja difícil e frustrante querer, no âmbito desta pesquisa, respostas ou indicações objetivas para uma escrita fundamentada no universo do incerto, do passageiro, do transversal, do irônico e do vazio das coisas. Na maioria das vezes, o espaço reservado pelas reticências na obra desse escritor, tanto pode ser acolhedor quanto resultar num incômodo, numa inapropriação - não se pode esquecer que essas e outras contrariedades também estão dadas pelo estatuto das reticências, que não são indicativas de acolhimento e pura positividade. Bellos nos alerta para algumas dessas astúcias contidas na obra perequiana:

\footnotetext{
A ajuda aparente de Perec ao leitor que procura por um mapa ou um guia é uma armadilha tipicamente gentil e eficaz que acaba nos forçando a encontrar nosso próprio caminho através do seu universo de palavras, do qual cada parte é diferente, e ainda assim um componente de um todo enganoso. ${ }^{519}$
}

Se o jogo faz parte da obra perequiana, o desvio e o trapacear também valem. Para escapar das artimanhas e das complexidades intransponíveis da obra dese autor, a sua relação

\footnotetext{
${ }^{518}$ Cf. item 3.4.2.

${ }^{519}$ Perec's apparent helpfulness to the reader looking for a map or guide is a characteristically gentle and effective trap, forcing us to find our own path through his universe of words, every part of which is different, and yet a constituent of an elusive whole. BELLOS. The Old and the New: An Introduction to Georges Perec. In: The review of contemporary fiction, 2009, p. 17.
} 
com a arte contemporânea se dá através de uma estratégia semelhante àquela adotada por Perec em $W$, ou seja, por meio de segundos, terceiros e quartos textos que, ao invés de explicar e justificar conexões, acabam por experimentar, arriscar, testar conflitos que atuam pelas margens, andam em paralelo no campo do espraiamento, das reverberações e contaminações. A obra perequiana estudada aceita aproximações com a arte contemporânea por aquilo que o texto perequiano traz de móvel, incerto, repetitivo, exagerado, promotor de crises e contrariedades, indicando ter ao mesmo tempo tanto um lastro com o passado quanto um trampolim para o futuro, pondo em prática o que Ardenne entende como o exercício incessante do contemporâneo:

O "contemporâneo" não é somente o agora, o "sendo", Dasein ${ }^{520}$ que não teria outra vocação que aquela de se realizar ao ritmo impulsionador do tempo que nasce, no esquecimento imediato disso que ele acaba de realizar. Um vai-e-vem, ou melhor, um ir e vir entre o que é, projetado no sentido do que será, e o que foi, base do que é. [...] A arte contemporânea é aparição contínua, "surgimento" (o Vorsprung heideggeriano ${ }^{521}$ ). Surgimento considerado sob o ângulo da surpresa (a arte não é necessariamente aguardada) mas também em função da sua quantidade, em relação a uma oferta de uma multiplicidade intensa. Notável por sua profusão inusitada, a arte contemporânea deve ser entendida como uma criação contínua, prodigalidade plástica crescente mais rápida que todo o conhecimento sobre a arte seria capaz de registrar. ${ }^{522}$

Concluo a tese com uma citação e uma anotação que resumem o propósito da pesquisa:

Gostaria de saber o que você busca. - Eu também gostaria.

Maurice Blanchot ${ }^{523}$

${ }^{520}$ DASEIN: o 'ser aí', imediato e inevitável da existência, 'alguma coisa', ou, como define Heidegger: "Esse ente, que nós mesmos sempre somos e que, entre as outras possibilidades de ser, possui a de quetionar, designamos com o termo Dasein." (Sein und Zeit, § 2). In: ABBAGNANO. Dicionário de Filosofia, 2007, p. 268.

${ }^{521}$ VORSPRUNG: um salto antecipativo. Cf.: HEIDEGGER. A origem da obra de arte, 2004, p. 61.

${ }^{522}$ Le “contemporain” n'est pas seulement le maintenant, l' "étant”, Dasein qui n'aurait de vocation que celle de s'accomplir au rhythme pulsif du temps qui naît, dans l'immédiat oubli de ce qu'il vient d'accomplir. Un va-et-vient, plutôt, un aller et retour entre ce qui est, projeté vers ce qui sera, et ce qui fut, socle de ce qui est.

[...] L'art contemporain est apparition continuelle, “surgissement” (la Vorsprung heideggerienne). Surgissement qu'il s'agit d'envisager sous l'angle de la surprise (l'art n'est pas forcément attendu) mais aussi en foction de sa quantité, au regard d'une offre d'une multiplicité intense. Signalé par sa profusion inouïe, l'art contemporain doit être compris comme une création continue, prodigalité plastique croissant plus vite que ne saurait l'enregistrer tout savoir sur l'art [...]. ARDENNE. Art. L'Âge Contemporain, 2003, p. 12.

${ }^{523}$ BLANCHOT. Falar, não é ver. In: A conversa infinita, 2010a, p. 63. 
Fim... 


\section{Referências bibliográficas}

Esta bibliografia foi expandida para incluir as obras que, mesmo importantes para a pesquisa, acabaram não sendo citadas na versão final da tese.

AA Files 45/46. Paris. Georges Perec. Architectural Association School of Architecture. London, 2001.

ABBAGNANO, Nicola. Dicionário de Filosofia. Revisão e Tradução $1^{\text {a }}$ Edição coordenada e revista por Alfredo Bosi / Revisão da tradução e novos verbetes Ivone Castilho Benedetti, $5^{\text {a }}$ edição. São Paulo: Martins Fontes, 2007.

ACCONCI, Vito. Steps into performance (And out) (BRONSON, A. A.; GALE, Peggy. Eds. Performance by Artists. Toronto, Art Metropole, 1979, pp. 28-40). In: STILES, Kristine; SELZ, Peter. (eds.). Theories and documents of contemporary art. A Soucebook of Artist's Writings. Berkeley: University of California Press, 1996, pp. 759-767.

ADAIR, Gilbert. The Eleventh Day: Perec and the Infra-ordinary. In: The Review of Contemporary Fiction, 2009, pp. 176-188.

AGAMBEN, Giorgio. O que é o contemporâneo. In: O que é o contemporâneo? E outros ensaios. Trad. Vinícius Nicastro Honesko. Chapecó: Argos, 2009, pp. 55-73.

ALBERRO, Alexander; STIMSON, Blake. (eds.). Conceptual art: a critical anthology. Cambridge: MIT Press, 2000.

ARCHER, Michael. Art since 1960. London: Thames and Hudson, 1997.

ARDENNE, Paul. Art. L'Âge Contemporain. Une histoire des arts plastiques à la fin du XXe siècle. Paris: Éditions du Regard, 2003.

. L'Artiste à l'Âge Contemporain: un acteur protéiforme. In: Art. L' Âge

Contemporain, 2003, pp. 21-32.

- Conceptualisme et Déconstruction. In:

Art. L'Âge Contemporain, 2003, pp. 93-110.

. Low as high. Un art du presque rien. In: . Art. L' Âge Contemporain, 2003, pp. 312-350.

Arman. Catálogo de Exposição. Centre Pompidou. Galerie 2. (22 septembre 2010 - 10 janvier 2011). Paris: Centre Pompidou, 2010. 
ARMAN. Réalisme des accumulations. (Tapuscrit, juillet 1960, Archives Yves Klein, Paris. Publié dans Zéro vol. 3, juillet 1961). In: Arman, 2010, p. 251.

Arman. Catálogo de Exposição. Paris, Galerie Nationale du Jeu de Paume (27 janeiro - 12 abril 1998); [...] São Paulo, Museu de Arte de São Paulo Assis Chateaubriand MASP (30 novembro 1999 - 9 janeiro 2000). Trad. Cecília Santos. Paris: Galerie Nationale du Jeu de Paume / MASP, 1998.

AUGÉ, Marc. Não-Lugares, Introdução a uma antropologia da supermodernidade. Trad. Maria Lúcia Pereira. Campinas: Papirus, 2001.

BACHELARD, Gaston. A poética do espaço. Trad. Antônio de Pádua Danesi. São Paulo: Martins Fontes, 2000.

BAJAC, Quentin. Le trouble du spectateur. In: LEVÉ. Reconstitutions. Angoisse, 2008a, pp. 89-92.

BANDEIRA, Manuel. Estrela da vida inteira. Poesias reunidas e poemas traduzidos. Rio de Janeiro: José Olympio, 1986.

BAQUÉ, Dominique. Photographie plasticienne, l'extrême contemporain. Paris: Éditions du Regard, 2004.

Le trope du banal. In: Photographie plasticienne, l'extrême contemporain, 2004, pp. 23-37.

BARTHES, Roland; BERSANI, Leo; HAMON, Philippe; RIFFATERRE, Michel; WATT, Ian. Literatura e realidade (que é o realismo?). Trad. Tereza Coelho. Lisboa: D. Quixote, 1984.

BARTHES, Roland. Euvres complètes. Tome I, 1942-1961. Éric Marty (org.). Paris: Seuil, 2002a.

. L'écriture et le silence. (Le Degré zéro de l'écriture, 1953). In: Euvres Complètes, 2002a, pp. 169-225.

- Commentaire: Préface à Brecht, "Mère courage et ses enfants" (avec des photographies de Pic). (L'Arche, 1960). In: . Euvres Complètes, 2002a, pp. 1064-1082.

. Euvres complètes. Tome II, 1962 - 1967. Éric Marty (org.). Paris: Seuil, 2002b. - Les choses signifient-elles quelque chose? (Propos recueillis par Pierre Fisson. Le Figaro Littéraire, 13 octobre 1962). In: . Euvres Complètes, 2002b, pp. 45-47. . Littérature objective. (Critique, 1954). (Essais Critiques, 1964). In: Euvres Complètes, 2002b, pp. 293-303. 
Le point sur Robbe-Grillet? (Préface à: Bruce Morrissette. Les Romans de RobbeGrillet. Paris: Minuit, 1963), (Essais Critiques, 1964). In: Euvres Complètes, 2002b, pp. 452-459.

. Euvres complètes. Tome III, 1968-1971. Éric Marty (org.). Paris: Seuil, 2002c. . $S / Z$. In : . Euvres complètes, 2002c, pp.119-346. . La mort de l'auteur. (Manteia, $4^{\circ}$ trimestre, 1968). In : Euvres complètes, 2002c, pp. 40-45.

. De l'oeuvre au texte. (Revue d'Esthétique, $3^{\mathrm{e}}$ trimestre, 1971). In : Euvres complètes, 2002c, pp. 908-916.

. Euvres complètes. Tome IV, 1972-1976. Éric Marty (org.). Paris: Seuil, 2002d. . Euvres complètes. Tome V, 1977-1980. Éric Marty (org.). Paris: Seuil, 2002e. La chambre claire. In: . Euvres complètes, 2002e, pp. 785-892.

. Mitologias. Trad. Rita Buongermino e Pedro de Souza. Rio de Janeiro: Bertrand Brasil, 2001.

. L’Ancienne Rhétorique. Aide-mémoire. In: Communications, 1970, pp. 172-229. - O Efeito do Real. (Communications, 11, 1968). In: BARTHES et al.. Literatura $\boldsymbol{e}$ realidade, 1984, pp. 87-97.

BATCHELOR, David. “Essa Liberdade e essa ordem”: A arte na França após a Primeira Guerra Mundial. In: FER; BATCHELOR; WOOD. Realismo, Racionalismo, Surrealismo, 1998, pp. 3-86.

BAUDRILLARD, Jean. Le système des objets. Paris: Gallimard, 1981.

BEAUMATIN, Eric; RIBIÈRE, Mireille (org.). De Perec etc., derechef. Textes, lettres, règles \& sens. Mélanges offerts à Bernard Magné. Nantes: Joseph K., 2005.

BELLOS, David. The Old and the New: An Introduction to Georges Perec. In: The review of contemporary fiction, 2009, pp. 11-20.

. Georges Perec - une vie dans les mots. Trad. Françoise Cartano e o autor. Paris: Seuil, 1994.

BÉNABOU, Marcel. Duchamp à l'Oulipo ou Un secret trop bien gardé. In: "regarde de tous tes yeux, regarde", 2008, pp. 74-84. . Quarante siècles d'Oulipo. In: Magazine Littéraire, 2001, pp. 20-26.

BENJAMIN, Walter. Paris, capital do século XIX. Trad. Maria Cecília Londres, revisão (3 ${ }^{\mathrm{a}}$ edição) Luiz Costa Lima. In: LIMA. Teoria da Literatura em suas fontes, 2002, pp. 689-706. 
Desempacotando minha Biblioteca. Um discurso sobre o colecionador. Trad. José

Carlos Martins Barbosa e Pierre Paul Michel Ardengo. In: Obras Escolhidas

II. Rua de Mão Única. Trad. Rubens Rodrigues Torres Filho, José Carlos Martins Barbosa. São Paulo: Brasiliense, 2000, pp. 227-235.

BLANCHOT, Maurice. A conversa infinita - 1. A palavra plural. (Palavra de escrita). Trad. Aurélio Guerra Neto. São Paulo: Escuta, 2010a.

Falar, não é ver. In: A conversa infinita, 2010a, pp. 63-72. A conversa infinita - 3. A ausência de livro. (O neutro o fragmentário). Trad. João Moura Jr. São Paulo: Escuta, 2010b.

. Fala de Fragmento. In: A conversa infinita, 2010b, pp. 41-48. - A rose is a rose. In: A conversa infinita, 2010b, pp. 85-92. . O efeito de estranhamento. In: A conversa infinita, 2010b, pp. 113-123. . A conversa infinita - 2. A experiência limite. Trad. João Moura Jr. São Paulo: Escuta, 2007. . A fala cotidiana. In: A conversa infinita, 2007, pp. 235-246.

BLANDINE, Chavanne. Marcel Duchamp. In: “regarde de tous tes yeux, regarde”, 2008, pp. 86-87.

Blurting in A \& L: Art \& Language and the investigation of context. Disponível em: 〈http://blurting-in.zkm.de/e/invest_context\#II.3>. Acesso em 26 ago. 2011.

BORSARI, Andrea (org.). Rivista Riga, n 4. Georges Perec. Milano: Marcos y Marcos, 1993.

BORSARI, Andrea. Entre oubli et mémoire. Georges Perec et les choses. In: Le Cabinet d'amateur, 1994, pp. 57-74.

BRAINARD, Joe. The Nancy book. Los Angeles: Siglio Press, 2008. I remember. New York: Granary Books, 2006.

BRASSEUR, Roland. Je me souviens encore mieux de Je me souviens. Notes pour Je me souviens de Georges Perec à l'usage des générations oublieuses et de celles qui n'ont jamais su. Bordeaux: Le Castor Astral, 2003.

BRAYER, Marie-Ange. Fabulations: les postures de l'artiste en écrivain. In: Art Press, Hors Série, no 13, 1992, pp. 44-48.

BRECHT, Bertolt. Estudos sobre teatro. Trad. Fiama Pais Brandão. Rio de Janeiro: Nova Fronteira, 2005.

BROWN, Bill (ed.). Things. Chicago: The University of Chicago Press, 2004. 
Thing Theory. In: Things, 2004, pp. 1-17.

BRUNEL, Pierre. Les Choses - Georges Perec. Profil d'une œuvre. Paris: Hatier, 2003.

BUCHLOH, Benjamin. Plenty or Nothing: from Yves Klein's le Vide to Arman's Le Plein. In: Premises, 1998, pp. 86-99.

BURGELIN, Claude. Georges Perec. Collection Les contemporains. Paris: Seuil, 2002. Esthétique et éthique de l'Oulipo. In: Magazine Littéraire, 2001, pp. 36-39. Les Parties de dominos chez Monsieur Lefèvre - Perec avec Freud, Perec contre Freud. Paris: Circé, 1996.

Cahiers Georges Perec $\mathbf{n}^{\mathbf{0}}$ 10. Perec et L'Art Contemporain. Jean-Luc Joly (org.). Bordeaux: Le Castor Astral, 2010.

Cahiers Georges Perec no 6. L'œil, d'abord... Georges Perec et la peinture. Paris: Seuil, 1996.

Cahiers Georges Perec no 1. Colloque de Cerisy. Juillet, 1984. Paris: POL, 1985.

CALVINO, Italo. Perec e il salto del cavallo. (La Repubblica, 16 maggio 1984). In: BORSARI. Rivista Riga, 1993, pp. 134-138.

CAMPROUX, Charles. La langue et le style des Choses de Georges Perec. (Les Lettres Françaises, 1966, n 1123). In : PEREC. Les choses, 1969, pp. 145-155.

CERTEAU, Michel de. A invenção do cotidiano. 1. Artes de fazer. Trad. Ephraim Ferreira Alves. Petrópolis: Vozes, 2009.

CHAVANNE, Blandine. Marcel Duchamp. In: “regarde de tous tes yeux, regarde”, 2008, pp. 86-87.

CHAVANNE, Blandine; DARY, Anne. Introduction. In: "regarde de tous tes yeux, regarde", 2008, pp. 8-9.

CLERC, Thomas. Angoisse. In: Galerie Loevenbruck. Paris. Disponível em: <http://www.loevenbruck.com/artist.php?id=leve\&view=download. $>$ Acesso em: 07 jan. 2010.

COLARD, Jean-Max. “Ma mort ne changera rien”. In: Les Inrockuptibles, 2007, pp. 34-37. Un cabinet d'amateurs. In: Les Inrockuptibles, 2003, pp. 44-45.

Colloque Hégémonie de l'ironie ? (1980-2008). Aix en Provence, 8 e 9 nov. 2007. (Fabula, 18 juin 2008). Disponível em: 〈http://www.fabula.org/colloques/sommaire978.php〉. Acesso em 05 nov. 2010.

Communications. v. 16. Recherches Rhétoriques. Paris: Seuil, 1970. v. 13. Les objets. Paris: Seuil, 1969. 
v. 2. Paris: Seuil, 1963.

COUTURIER, Élisabeth. L'Art Contemporain mode d'emploi. Levallois Perret: Filipacchi, 2004.

CSIKSZENTMIHALYI, Mihaly; ROCHBERG-HALTON, Eugene. The meaning of things. Domestic symbols and the self. Cambridge: Cambridge University Press, 1999.

Cult, Revista Brasileira de Literatura. (Dossiê Cult - Oulipo). n 52, ano V, nov. 2001, pp. 45-63.

DAHLET, Véronique. As (man)obras da pontuação. Usos e significações. São Paulo: Humanitas, 2006. - $O$ dizer em silêncio: as reticências. In: I Seminário Nacional de Linguística e

Língua Portuguesa. Discurso, Sociedade e Ensino. Anais. Universidade Federal de Goiás, 1995, pp. 20-27.

DANTO, Arthur C. A transfiguração do lugar-comum. Uma filosofia da arte. Trad. Vera Pereira. São Paulo: Cosac Naify, 2005.

DEPAULE, Jean-Charles. A City in words and numbers. A conversation between JeanCharles Depaule \& Pierre Getzler. Trad. Clare Barrett. In: AA Files 45/46, 2001, pp. 117-128.

DERRIDA, Jacques. Et cetera (and so on, und so weiter, and so forth, et ainsi de suite, und so überall, etc.). Paris: L'Herne, 2005.

. Mal de arquivo. Uma impressão freudiana. Trad. Claudia de Moraes Rego. Rio de Janeiro: Relume Dumará, 2001.

DIDIER, Béatrice; NEEFS, Jacques. (Orgs.) Penser, Classer, Écrire de Pascal à Perec. Saint-Denis : Presses Universitaires de Vincennes, 1990.

Douze ans d'art contemporain en France, 1960-1972. Catálogo da Exposição. Grand Palais (mai-septembre 1972). Paris: Réunion des Musées Nationaux, 1972.

DREHER, Thomas. Index Systems. In: Blurting in A \& L: Art \& Language and the investigation of context. July 2001/April 2002. Disponível em: <http://blurtingin.zkm.de/e/invest_context\#II.3>. Acesso em 26 ago. 2011.

DUQUESNE, Dominique. Les Choses - Georges Perec. Parcours de Lecture. Paris: Bertrand-Lacoste, 2001.

DUVIGNAUD, Jean. Perec ou la cicatrice. Arles: Actes Sud, 1993.

ECO, Umberto. Les objets d'Arman. In: Arman, 2010, pp. 36-39.

The Infinity of Lists. Translation Alastair McEwen. New York: Rizzoli, 2009. 
Sobre Arman. In: Arman, 1998, pp. 15-21.

ESCHAPASSE, Maurice. L'avènement de l'objet. In: Douze ans d'art contemporain en France, 1960-1972, 1972, pp. 59-66.

FER, Briony; BATCHELOR, David; WOOD, Paul. Realismo, Racionalismo, Surrealismo. A arte no entre-guerras. Trad. Cristina Fino. São Paulo: Cosac \& Naify, 1998.

FLAUBERT, Gustave. L'Education sentimentale. Paris: Pocket, 2007.

FLEURY, Alice. Édouard Levé. In: “regarde de tous tes yeux, regarde”, 2008, p. 107.

FOUCAULT, Michel. $O$ a priori histórico e o arquivo. In: . A Arqueologia do Saber. Trad. Luiz Felipe Baeta Neves. Rio de Janeiro: Forense Universitária, 2008, pp. 143149.

O que é um autor? (1969). In: Estética: literatura e pintura, música e cinema. Manoel Barros da Motta (org.). Trad. Inês Autran Dourado Barbosa. Rio de Janeiro: Forense Universitária, 2006, pp. 264-298.

FRANCBLIN, Catherine. Les Nouveaux Réalistes. Paris: Éditions du Regard, 1997. La passion du réel. In: Art press, Hors Série, nº 13, 1992, pp. 35-43.

GABRIEL, Fabrice. L'homme qui (se) cherche. In: Les Inrockuptibles, 2003, pp. 38-44.

Genesis - Revue Internationale de Critique Génétique. Nº 1. Paris: Item/CNRS, 1992.

GOOCH, Brad. Nancy ideas. In: Artforum International, February, 2001, pp. 124-128.

GORP, Hendrik van; DELABASTITA, Dirk; D’HULST, Lieven; GHESQUIERE, Rita; GRUTMAN, Rainier; LEGROS, Georges. Dictionnaire des Termes Littéraires. Paris: Champion classiques, 2005.

GROMOVA, T. Notes. In: PEREC. Les choses, 1969, pp. 156-178

Grupo Cause Commune. O apodrecimento das Sociedades. Trad. António Martinho Baptista. Amadora: Bertrand, 1977.

HARRISON, Charles; WOOD, Paul. (eds.) Art in theory. 1900 - 2000. An Anthology of Changing Ideas. Malden: Blackwell, 2009.

HARTJE, Hans. Georges Perec écrivant. Thèse pour le doctorat de Littérature Française sous la direction de Monsieur le Professeur Jacques Neefs. Université Paris VIII. Vincennes à Saint-Denis. Mai 1995.

HEIDEGGER, Martin. Ensaios e conferências. Trad. Emmanuel Carneiro Leão, Gilvan Fogel, Marcia Sá Cavalcante Schuback. Petrópolis: Vozes, 2006. . A coisa. Trad. Emmanuel Carneiro. In: . Ensaios e conferências, 2006, pp. 143-164. 
A origem da obra de arte. Trad. Maria da Conceição Costa. Lisboa: Edições 70, 2004.

. Que é uma coisa? Trad. Carlos Morujão. Lisboa: Edições 70, 2002.

- Os diferentes modos de questionar acerca da coisa. In: Que é uma coisa?, 2002, pp. 13-59.

Que é metafísica? Trad. Ernildo Stein. Revisão José Geraldo Nogueira Moutinho. São Paulo: Livraria Duas Cidades, 1969.

HENDERSON, Suzanne. Étude sur Les Choses - Georges Perec. Paris: Ellipses, 2007.

HOUAISS - Dicionário Eletrônico da Língua Portuguesa 3.0. Rio de Janeiro: Objetiva, 2009.

JOLY, Jean-Luc. Le “romans" de l'artiste contemporain. In: "regarde de tous tes yeux, regarde”, 2008, pp. 34-50.

- Une leçon des Choses : approche de la poétique perecquienne de la totalité. In: BEAUMATIN; RIBIÈRE. De Perec etc., derechef, 2005, pp. 237-253.

KEIM, Jean. A.. La photographie et sa légende. In: Communications, 1963, pp. 41-55.

L’Arc, no 76, Georges Perec. (1979). Paris: Inculte, 2005.

LAUTERBACH, Ann. Joe Brainard \& Nancy. In: BRAINARD. The Nancy book, 2008, pp. 7-24.

LEAK, Andrew. Phago-citations: Barthes, Perec, and the Transformation of Literature. In :

The Review of Contemporary Fiction, 2009, pp. 124-147.

Paris: Created and Destroyed. In : AA Files 45/46, 2001, pp. 25-31.

Le Cabinet d'amateur. Revue d'études perecquiennes. Printemps 94, nº 3. Miscellanées II. Paris: Les Impressions Nouvelles, 1994.

LEJEUNE, Philippe. Une autobiographie sous contrainte. In: Magazine Littéraire, 1993, pp. $18-21$.

. Vilin Souvenirs, Georges Perec. In: Genesis, 1992, pp. 127-151.

. La mémoire et l'oblique - Georges Perec autobiographe. Paris: POL, 1991.

LE SIDANER, Jean-Marie. Entretien avec Georges Perec. (1979). In: L’Arc, 2005, pp. 2339.

Les Inrockuptibles. $n^{\circ} 621.23$ octobre, 2007.

Perec la (ré)apparition. no 401. Du 6 au 12 août, 2003.

LEVÉ, Édouard. Reconstitutions. Angoisse. Paris: Nicolas Chaudun, 2008a.

Interview d'Édouard Levé para lui-même. In : Reconstitutions. Angoisse. 2008a, pp. 84-87. 
Autoportrait. Paris: P.O.L, 2008b.

Amérique. Paris: Léo Scheer, 2006.

Euvres. Paris: P.O.L, 2002.

LEWALLEN, Constance M. (with essays by John Ashberry and Carter Ratcliff). Joe Brainard. A retrospective. Catálogo da Exposição. University of California, Berkeley Art Museum, Berkeley, California (February 7 - May 27, 2001); [...]. Berkeley Art Museum. San Diego: University of California, Granary Books, 2001.

. Acts of Generosity. In: . Joe Brainard, 2001, pp. 5-46.

LEWITT, Sol. Paragraphs on conceptual art. (Artforum, 5:10, Summer 1967, pp. 79-84). In: ALBERRO; STIMSON. (eds.). Conceptual art: a critical anthology, 2000, pp. 12-16. LIMA, Luiz Costa (org.). Teoria da Literatura em suas fontes. Vol. 2. Rio de Janeiro: Civilização Brasileira, 2002.

LIPPARD, Lucy R. (org.); ALLOWAY, Lawrence; MARMER, Nancy; CALAS, Nicolas. $\boldsymbol{A}$ Arte Pop. Trad. H. Silva Letra. São Paulo: Verbo/Edusp, 1976.

LIPPARD, Lucy R. O “Pop” de Nova Iorque. In: LIPPARD et al.. Arte Pop, 1976, pp. 75149. . Europa e Canadá. In: LIPPARD et al.. Arte Pop, 1976, pp. 187-215.

LUKÁCS, Georges. Problèmes du réalisme. Trad. Claude Prévost e Jean Guégan. Paris: L'Arche, 1975. . Raconter ou Décrire. (1936). In: . Problèmes du réalisme, 1975, pp. 130-175. . La Signification présente du Réalisme Critique. Trad. Maurice de Gandillac. Paris: Gallimard, 1960. . Franz Kafka ou Thomas Mann? In: La Signification présente du Réalisme Critique, 1960, pp. 86-168.

LOWRY, Malcolm. À sombra do vulcão. Trad. Leonardo Fróes. São Paulo: Siciliano, 1992.

MACIEL, Maria Esther. A memória das coisas. Ensaios de literatura, cinema e artes plásticas. Rio de Janeiro: Lamparina, 2004.

Magazine littéraire. L'Angoisse, du péché originel à l'anxiété moderne. $\mathrm{n}^{\circ} 422$, juillet-août, 2003.

. L'Oulipo - la littérature comme jeu. no 398, mai, 2001.

. Dossier Perec. n 316, décembre, 1993.

. Georges Perec mode d'emploi. nº 193, mars, 1983. 
MAGNÉ, Bernard. Ironies Péréquiennes. In: Colloque Hégémonie de l'ironie ? Disponível em: 〈http://www.fabula.org/colloques/document988.php>. Acesso em 05 nov. 2010. . Notice. (La Disparition). In: PEREC. Romans \& Récits, 2004c, pp. 306-309. . Georges Perec romancier. In: PEREC. Romans \& Récits, 2004c, pp. 9-34. . Georges Perec, l'oulibiographe. In: Magazine Littéraire, 2001, pp. 52-55. . Georges Perec. Collection 128. Paris: Nathan, 1999. - Textus ex machina (de la contrainte considérée comme machine à écrire dans quelques textes de Georges Perec). In: Perecollages, 1989, pp. 219-229.

MARGATO, Izabel; GOMES, Renato Cordeiro. (org.) Espécies de Espaço. Territorialidades, Literatura, Mídia. Belo Horizonte: Editora UFMG, 2008.

MILLET, Catherine. L'Art Contemporain en France. Paris : Flammarion, 1987.

MOLES, A. Abraham. Théorie des objets. Paris: Éditions Universitaires, 1972. . Objet et communication. In: Communications, 1969, pp. 1-21.

MOLTENI, Patrizia. Perec's Painterly Eye. In : The Review of Contemporary Fiction, 2009, pp. 210-223.

MORAN, Patrícia. Poéticas das correspondências. In: NOVA; ARBEX; BARBOSA. Interartes, 2010, pp. 246-257.

MORICE, Jacques. L'écrivain et photographe Édouard Levé est mort. 22 oct. 2007. (Télérama $\mathrm{n}^{\circ}$ 2888, 2005). Disponível em: <http://www.telerama.fr/livre/20937ecrivain_et_photographe_edouard_leve_est_mort.php>. Acesso em: 16 dez. 2009. . La lumière noire d'Edouard Levé, plasticien, écrivain... suicidé. In: Télérama ${ }^{\circ}$ 3046, 31 mai 2008. Disponível em: <http://www.telerama.fr/livre/la-lumierenoire,29532.php.> Acesso em: 09 fev. 2010.

MORIN, Violette. L'objet biographique. In: Communications, 1969, pp. 131-139.

NEEFS, Jacques; HARTYE, Hans. Georges Perec. Images. Paris: Seuil, 1993.

NEEFS, Jacques. Des lieux, des pages, des æeuvres. In: Magazine Littéraire, 1993, pp. 35-37. NOVA, Vera Casa; ARBEX, Márcia; BARBOSA, Márcio Venício. (org.) Interartes. Belo Horizonte: Editora UFMG, 2010.

OULIPO. La littérature potentielle. (Créations, Re-créations, Récréations). Paris: Gallimard, 2003a. . Atlas de littérature potentielle. Paris: Gallimard, 2003b.

ØRUM, Tania. Perec et l'avant-garde dans les arts plastiques. In: SESTOFT; JØRGENSEN. Georges Perec et l'histoire, 2000, pp. 201-213. 
PADGET, Ron. Afterword. In: BRAINARD. I remember. New York: Granary Books, 2006, pp.169-176.

PADGETT, Ron; PADGET, Pat. An Interview with Joe Brainard. (PADGETT, Ron; BERRIGAN, Ted. Bean Spasms. New York: Kulchur, 1967). New York, 1964. In: LEWALLEN. Joe Brainard, 2001, pp. 91-97.

Parade, 1901-2001. Coleções do Centro Pompidou, Museu Nacional de Arte Moderna, Centro de Criação Industrial. Nelson Aguilar, Laurent Le Bon (org.). Catálogo da Exposição. (2 de outubro de 2001 a 15 de janeiro de 2002). Pavilhão Lucas Nogueira Garcez - OCA, Parque Ibirapuera, São Paulo. Trad. Carlos Spilak. São Paulo: BrasilConnects, 2001.

PAWLIKOWSKA, Ewa. Entretien Georges Perec / Ewa Pawlikowska. (Propos recueillis le 5 avril 1981, à Varsovie, transcription d' Ewa Pawlikowska). In: PEREC. Entretiens et Conférences, 2003b, pp. 199-207.

PEREC, Georges. A Vida modo de usar. Trad. Ivo Barroso. São Paulo: Companhia das Letras, 2009.

. Tentative d'épuisement d'un lieu parisien. Paris: Christian Bourgois, 2008. Je suis né. Paris: Seuil, 2006.

Lettre à Maurice Nadeau. (Lundi 7 juillet 1969). In: Je suis né, 2006, pp. 51-66.

. Les gnocchis de l'automne ou Réponse à quelques questions me concernant. (Cause Commune, $\mathrm{n}^{\circ} 1$, mai 1972, pp. 19-20). In: . Je suis né, 2006, pp. 67-74.

. Je me souviens - Les choses communes (1). Paris: Hachette, 2004a.

La disparition. Paris: Gallimard, 2004b.

Romans \& Récits. Paris: Le Livre de Poche, 2004c.

Les revenentes. In: Romans \& Récits, 2004c, pp. 563-639.

Entretiens et Conférences, v. 1. Édition critique établie par Dominique Bertelli et Mireille Ribière. Nantes: Joseph K, 2003a.

. Georges Perec, lauréat du "Renaudot". (Propos recueillis par Adrien Jans, Le Soir, Bruxelles, 2 décembre 1965). In: Entretiens et conférences, 2003a, pp. 4244.

. Le bonheur est un processus... on ne peut pas s'arrêter d'être heureux. (Propos recueillis par Marcel Bénabou et Bruno Marcenac, Les Lettres Françaises, nº 1108, 2 8 décembre 1965). In: . Entretiens et Conférences, 2003a, pp. 45-51. 
Le bonheur de la modernité. (Propos recueillis par Jean Duvignaud, Le Nouvel Observateur, $\mathrm{n}^{\circ}$ 57, 15-21 décembre 1965). In: Entretiens et conférences, 2003a, pp. 58-62.

. Pouvoirs et limites du romancier français contemporain. (Conférence prononcée le 5 mai 1967 à l'Université de Warwick, Conventry, Angleterre. Transcription de Leslie Hill). In: Entretiens et Conférences, 2003a, pp. 76-88.

- Georges Perec: 'J'utilise mon malaise pour inquiéter mes lecteurs'. (Propos recueillis par Anne Redon, Coopérateur de France, $1^{\text {er }}-15$ décembre 1969). In : Entretiens et Conférences, 2003a, pp. 106-111.

. Complement 1- Cause commune: éditorial du premier numéro (mai 1972). In: . Entretiens et Conférences, 2003a, pp. 133-134.

. Georges Perec: “des règles pour être libre”. (Propos recueillis par Claude Bonnefoy, Les Nouvelles littéraires, $\mathrm{n}^{\circ}$ 2575, 10-16 mars 1977). In:

Entretiens et Conférences, 2003a, pp. 206-208.

. Ce qu'il se passe quand il ne se passe rien. (Propos recueillis par Monique Pétillon, Le Monde, 10 février 1978). In: Entretiens et Conférences, 2003a, pp. 214216. «

. La vie: règle du jeu. (Propos recueillis par Alain Hervé, Le Sauvage : Le Nouvel Observateur-Écologie, n 60: “Le jeu”, décembre 1978). In : Entretiens et Conférences, 2003a, pp. 267-285.

. Entretiens et Conférences, v. 2. Édition critique établie par Dominique Bertelli et Mireille Ribière. Nantes: Joseph K, 2003b.

. En dialogue avec l'époque. (Propos recueillis par Patrice Fardeau, France nouvelle, $\mathrm{n}^{\circ} 1744,16-22$ avril 1979). In: . Entretiens et Conférences, 2003b, pp. 55-68. - La vie est un livre. (Propos recueillis par Jean Royer, Le Devoir, Montréal, 2 juin 1979), (Entretien repris dans: Jean Royer, Écrivains contemporains. Entretiens 1, 1976-1979, Montréal, L’Hexagone, 1982). In: Entretiens et Conférences, 2003b, pp. 75-79.

- "Pour Georges Perec, le banal est explosif." (Propos recueillis par Réginald Martel, La Presse, Montréal, 2 juin 1979). In: Entretiens et Conférences, 2003b, pp. 80-83.

. ... Sono un "archivista", ma della invenzione che "crea" la realtà quotidiana... (Propos recueillis par Raffaella di Ambra, Uomini e libri. Periodico bimestrale di 
critica e di informazione letteraria, Milan, vol. XV, $\mathrm{n}^{\circ} 74$, juin-juillet 1979 - traduit de l'italien par Dominique Bertelli). In: Entretiens et Conférences, 2003b, pp. $84-87$.

. The Doing of Fiction. (Propos recueillis par Kaye Mortley le 24 août 1981, à Paris. Traduction Mireille Ribière. The Review of Contemporary fiction, 1993). In:

Entretiens et Conférences, 2003b, pp. 244-262.

- À propos des Choses. (Conférence prononcée à l'Université d'Adélaïde le $1^{\text {er }}$ octobre 1981 - transcription de Mireille Ribière et Dominique Bertelli). In:

Entretiens et Conférences, 2003b, pp. 264-272.

. À propos des Choses (bis). (Conférence prononcée à l'Université de Melbourne le 5 octobre 1981 - transcription de Mireille Ribière et Dominique Bertelli). In:

Entretiens et Conférences, 2003b, pp. 273-280.

- Création et contraintes dans la production littéraire. (Conférence prononcée à l'Université de Copenhague le 29 octobre 1981 - transcription de Mireille Ribière et Dominique Bertelli). In: . Entretiens et Conférences, 2003b, pp. 307-323. - Art et poésie: le livre illustré. (Propos tenus lors d'une table ronde, le 28 novembre 1981 à Bologne - transcription d'Eusebio Ricci et Éric Beaumatin). In:

Entretiens et Conférences, 2003b, pp. 329-338.

. Penser / Classer. Paris: Hachette, 2003c.

. Notes sur ce que je cherche. (Le figaro, 8/12/1978, p. 28). In: Penser /

Classer, 2003c, pp. 9-12.

. Trois chambres retrouvées. (Les Nouvelles Littéraires, no 2612, 24 novembre 1977, p. 20). In: Penser / Classer, 2003c, pp. 25-29.

- Notes brèves sur l'art et la manière de ranger ses livres. (L'Humidité, $\mathrm{n}^{\circ} 25$, printemps 1978, pp. 35-38). In: . Penser / Classer, 2003c, pp. 31-42.

. Lire: esquisse socio-physiologique. (Esprit, no 453, janvier 1976, pp. 9-20). In: Penser / Classer, 2003c, pp. 107-125.

. “Penser/Classer”. (Le Genre Humain, no 2, 1982, pp. 111-127). In: Penser / Classer, 2003c, pp. 149-174.

.W ou le souvenir d'enfance. Paris: Denoël, 2003d. . Histoire du lipogramme. In: OULIPO. La littérature potentielle, 2003a, pp. 73-89. What a man! In: OULIPO. Atlas de littérature potentielle, 2003b, pp. 214-216. . Les choses, une histoire des années soixante. Paris: Pocket, 2002. 
Glances at Gaîté. (Guettée. Les Lettres Nouvelles, 1977, nº1). Trad. Andrew Leak. In: AA Files 45/46, 2001, pp. 42-53.

. Stances on Mabillon. (Station Mabillon. Action poétique, $n^{\circ} 8,1980$.). Trad. Andrew Leak. In: AA Files 45/46, 2001, pp. 68-77.

W ou a memória da infância. Trad. Paulo Neves. São Paulo: Companhia das Letras, 1995.

Espèces d'espaces. Paris: Galilée, 1994a.

La Vie mode d'emploi. Paris: Hachette, 1994b.

L'esprit des choses. In: Le Cabinet d'amateur, 1994, pp. 37-56.

La boutique obscure - 124 rêves. Paris: Denoël, 1993.

La chose. (Texto inédito). In: Magazine littéraire, 1993, pp. 55-64.

L. G. Une aventure des années soixante. Paris: Seuil, 1992.

Pour une littérature réaliste. (Partisans no 4, avril-mai 1962, pp. 121-130). In: L. G., 1992, pp. 47-66.

. L'univers de la science-fiction. (Partisans $\mathrm{n}^{\mathrm{o}}$ 10, mai-juin 1963, pp. 118-130). In: . L. G., 1992, pp. 115-139.

L'infra-ordinaire. Paris: Seuil, 1989.

. Approches de quoi? (Cause commune, $\mathrm{n}^{\circ}$ 5, février, 1973, pp. 3-4) In:

L'infra-ordinaire, 1989, pp. 9-13.

. La rue Vilin. (L'Humanité, 11/11/ 1977). In :

L'infra-ordinaire, 1989, pp. 15-3.

. La Clôture et autres poèmes. Paris: Hachette, 1980.

. Allées et venues rue de l'Assomption. In: L’Arc, 1979, pp. 77-95.

- Leitura exaustiva de um lugar parisiense - ou as ruínas de Paris. (1973). In: Grupo

Cause Commune. O apodrecimento das Sociedades, 1977, pp. 39-65.

. Vues d'Italie. In: Écrire la psychanalyse. Nouvelle Revue de Psychanalyse, no 16, automne, 1977. Gallimard, pp. 239-246.

. As coisas. Uma história dos anos sessenta. Trad. T. C. Netto. São Paulo: Nova Crítica, 1969.

. Les choses. Une histoire des années soixante. Moscou: Éditions du Progres, 1969.

- À propos de la description. (Communication prononcée au colloque d'Albi "Espace

et représentation", 20-25 juillet 1981). In : RENIER. Espace \& Représentation, 1989, pp. 323-346. 
. Tentative de description d'un programme de travail pour les années à venir. (décembre 1976). In : Cahiers Georges Perec n 1, 1985, pp. 323-326.

PEREC, Paulette (Éd.). Portrait(s) de Georges Perec. Paris: Bibliothèque Nationale de France, 2001.

PEREC, Georges; BURGELIN, Claude. Le Nouveau Roman et le refus du réel. (Partisans, $\mathrm{n}^{\circ}$ 3, février 1962, pp. 108-118). In: L. G., 1992, pp. 25-45.

PEREC, Georges; WHITE, Cuchi. L'œil ébloui. Paris: Éditions du Chêne, 1987.

PINO, Claudia Amigo. A Ficção da Escrita. São Paulo: Ateliê Editorial, 2004. . A ressignificação do mundo. (Dossiê Cult - Oulipo). In: Cult, 2001, pp. 45-53.

PO, Guillaume. Perec et Boltanski, deux interrogations sur la disparition. In: Cahiers Georges Perec no 6, 1996, pp. 207-213.

POUILlOUX, Jean-Yves. L'amour de l'oeil. In : PEREC, Paulette (Éd.). Portrait(s) de Georges Perec, 2001, pp. 149-165.

Lieux psychanalytiques. In : Magazine Littéraire, 1993, pp. 43-46. .Histoires d'E. In: Magazine littéraire, 1983, pp. 24-25.

POUS, Bernard. Entretien Georges Perec / Bernard Pous. (Propos recueillis le 20 mars 1981 à Paris, transcription de Mireille Ribière et Dominique Bertelli). In: PEREC. Entretiens et Conférences, 2003b, pp. 181-198.

Premises: invested spaces in visual arts, architecture, \& design, from France 1958 - 1998. Catálogo de Exposição. New York: Guggenheim Museum, 1998.

PRUNIER, Patricia. Entretien Georges Perec / Patricia Prunier. (Propos recueillis par Patricia Prunier le 2 mai 1967, à Paris). In: PEREC. Entretiens et conférences, 2003a. pp. 69-75.

RATCLIFF, Carter. Attending to the ordinary. In: Art in America, July 1997, pp. 72-76. . Joe Brainard's Quiet Dazzle. In: LEWALLEN. In: . Joe Brainard, 2001, pp. 49-69.

“regarde de tous tes yeux, regarde" - L'art contemporain de Georges Perec. Catálogo da Exposição. Nantes: Joseph K. / Musée des Beaux-arts de Nantes / Musée des Beauxarts de Dole, 2008.

REGGIANI, Cristelle. L'écriture photographique de Georges Perec. In: "regarde de tous tes yeux, regarde”, 2008, pp. 60-66.

. Perec : une poétique de la photographie. In: Le Cabinet d'amateur. Revue d'études perecquiennes, dirigée par Bernard Magné et Dominique Bertelli. 2001. Disponível 
em: 〈http://www.cabinetperec.org/articles/reggiani/reggiani.html>. Acesso em: 20 dez. 2007.

RENIER, Alain. (Dir.). Espace \& Représentation. Paris: Les Éditions de la Villette, 1989.

RESTANY, Pierre. Os novos realistas. Trad. Mary Amazonas Leite de Barros. São Paulo: Perspectiva, 1979. . A Pop'Art. In: Os novos realistas, 1979, pp. 131-141.

ROBBE-GRILLET, Alain. Pour un Nouveau Roman. Paris: Minuit, 2006. . Une voie pour le roman futur. (1956). In: . Pour un Nouveau Roman, 2006, pp. 15-23.

ROBIN, Régine. Georges Perec, Paris-nostalgie. Lieux, non-lieux, et le hors-lieu de l'écriture. In: PEREC, Paulette (Éd.). Portrait(s) de Georges Perec, 2001, pp. 180198.

ROSENFELD, Anatol. O teatro épico. São Paulo: Buriti, 1965. O teatro épico de Brecht. In: O teatro épico, 1965, pp. 143-176.

ROUBAUD, Jacques. S'écrire sous la contrainte (remarques 1967 - 1999). In : PEREC, Paulette (Éd.). Portrait(s) de Georges Perec, 2001, pp. 118-123. . Le démon de la forme. In: Magazine littéraire, 1993, pp. 65-67. . Notes sur la poétique des listes chez Georges Perec. In: DIDIER; NEEFS. Penser, Classer, Écrire de Pascal à Perec, 1990, pp. 201-208.

ROUILLÉ, André. L'Art d'après la photographie. In: "regarde de tous tes yeux, regarde", 2008, pp. 26-33.

. La photographie. Entre document et art contemporain. Paris: Gallimard, 2006. . L'ordinaire, le dérisoire. In : La photographie, 2006, pp. 560-564.

SALGAS, Jean-Pierre. Le Centre Georges Perec. In: "regarde de tous tes yeux, regarde", 2008, pp. 9-25.

SCHILLING, Derek. Mémoires du quotidien: les lieux de Perec. Villeneuve d'Ascq: Presses Universitaires du Septentrion, 2006.

SESTOFT, Carsten; JØRGENSEN, Steen Bille. (ed.). Georges Perec et l'histoire. Actes du colloque International de l'Institut de Littérature Comparée Université de Copenhague du 30 avril au $1^{\text {er }}$ mai 1998. Études Romanes $n^{\circ}$ 46. Université de Copenhague: Museum Tusculanum Press, 2000.

SHERINGHAM, Michael. Everyday Life. Theories and Practices from Surrealism to the Present. Oxford: Oxford University Press, 2006. 
SHÔNAGON, Sei. O Livro de Travesseiro. Trad. do japonês Andrei dos Santos Cunha. Porto Alegre: Escritos, 2008.

SILVA, Edson Rosa da. Inventário e Imaginação. Escrever/Escavar o(s) espaço(s) etc. In: MARGATO; GOMES. Espécies de Espaço, 2008, pp. 305- 315.

SIMONY, Gabriel. Entretien avec Gabriel Simony. (Propos recueillis en juin 1981 à Paris). In: PEREC. Entretiens et conférences, 2003b, pp. 208-226.

SOURIAU, Étinenne. A Correspondência das Artes. Elementos de Estética Comparada. São Paulo: Cultrix / Edusp, 1989.

SPERANZINI, Manlio de M.. Arquiteturas possíveis. A construção do sentimento morador. 2 volumes, 1 cd. Dissertação de Mestrado. Orientação do Prof. Dr. Artur Matuck. Programa Interunidades em Estética e História da Arte. 2005. Disponível em: <http://www.teses.usp.br/teses/disponiveis/93/93131/tde-03062011-141357/ptbr.php>. Acesso em 29 set. 2011. . Aqui tem coisa. Georges Perec e a Arte Contemporânea. Criação \& Crítica, $\mathrm{n}^{\circ} 3$, 2009. 144-159. pp. Disponível em: <http://www.fflch.usp.br/dlm/criacaoecritica/dmdocuments/13CC_N3_MSperanzini.p

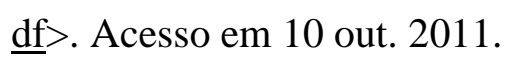

STILES, Kristine; SELZ, Peter (eds.). Theories and documents of contemporary art. A Soucebook of Artist's Writings. Berkeley: University of California Press, 1996.

The review of contemporary fiction. Spring 2009. vol. XXIX. № 1. Georges Perec Issue. Champaign: University of Illinois, 2009.

VENAILLE, Frank. Le travail de la mémoire. Entretien avec Frank Venaille. ("Perec le contraire de l'oubli”, Monsieur Bloom, no 3, mars 1979, pp. 72-75). In: PEREC. Je suis né, 2006, pp. 81-93.

VERDIER, Évence. Édouard Levé du singulier au pluriel. In: Art Press no 327, octobre 2006, pp. 48-51.

VERLET, Agnès. L'angoisse d'écrire. In: Magazine littéraire, 2003, pp. 22-25.

VERNE, Jules. Michel Strogoff. Paris: Pocket, 2007.

VILLENEUVE, Mathilde. Interview. [com Édouard Levé] 15 juin 2003. In: Paris-Art. Disponível em: <http://www.paris-art.com/interview-artiste/Édouard\%20Levé/LevéEdouard/31.html.> Acesso em: $11 \mathrm{dez} .2009$.

WALDMAN, Anne. An interview with Joe Brainard. (New York City, 1978), (Rocky Ledge 3 November/December 1979). In: LEWALLEN. Joe Brainard, 2001, pp. 101-105. 
WALKER, Enrique. Paul Virilio on Georges Perec. Interview by Enrique Walker. Trad. Ian Monk. In: AA Files 45/46, 2001, pp. 15-18.

WEINER, Lawrence. Statements. (The Statement of 12 oct. 1969, MEYER, ed., Conceptual Art, New York, 1972, pp. 217-218). In: HARRISON; WOOD. Art in theory. 1900 2000, 2009, pp. 893-894.

WHITE, Edmund. Saint Joe. In: Art in America, July 1997, pp. 78-81.

WOOD, Paul. Arte Conceitual. Trad. Betina Bischof. São Paulo: Cosac \& Naify, 2002. 